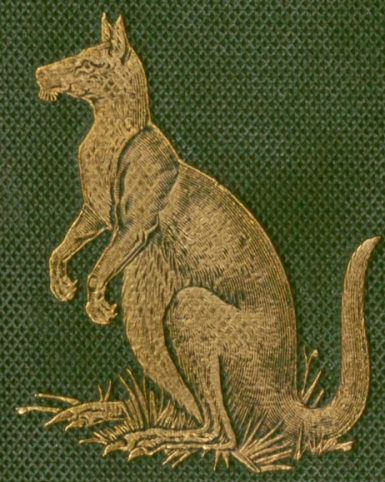



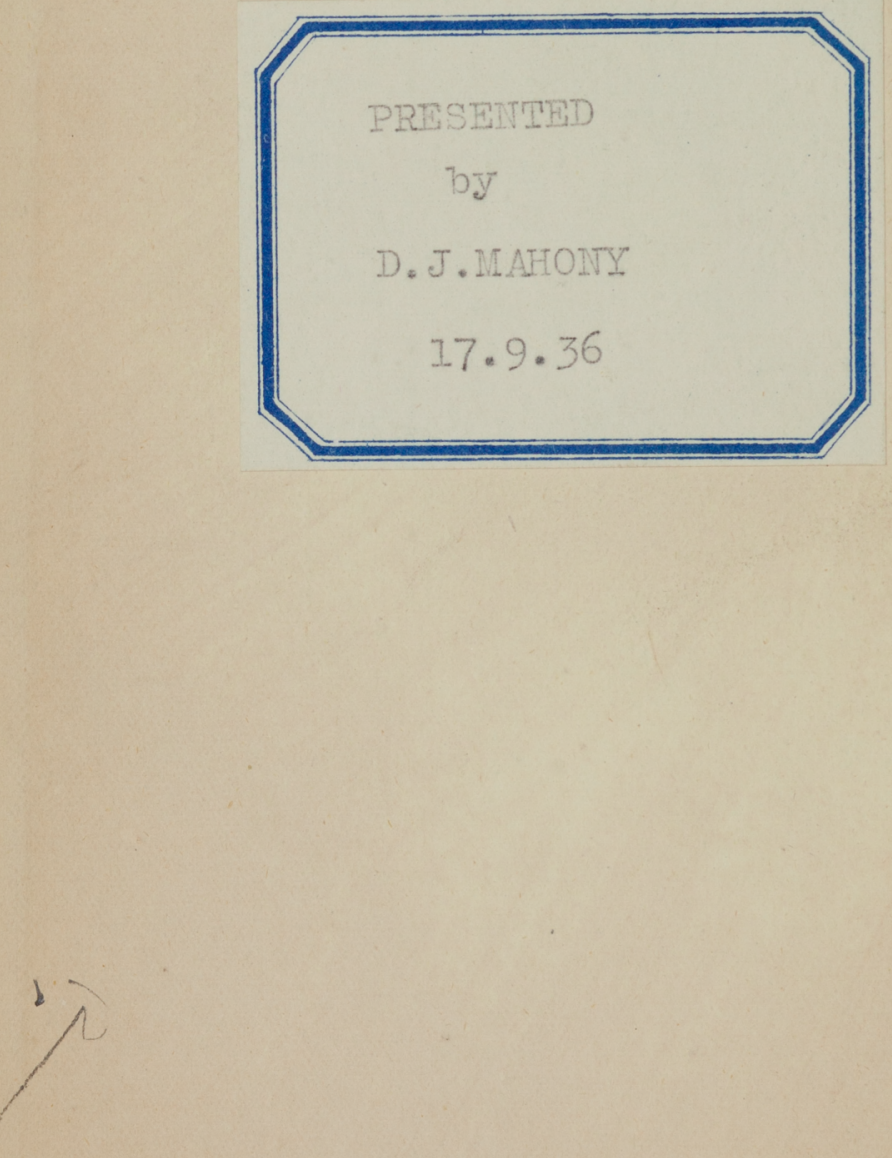


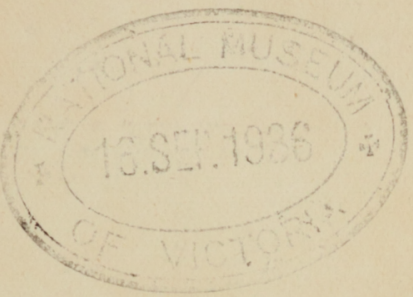

MUSEUM OF VICTORIA

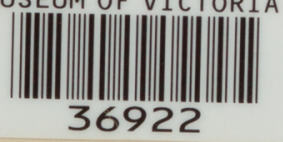



A SKETCH OF THE

- natural history of aUstralia 
S 



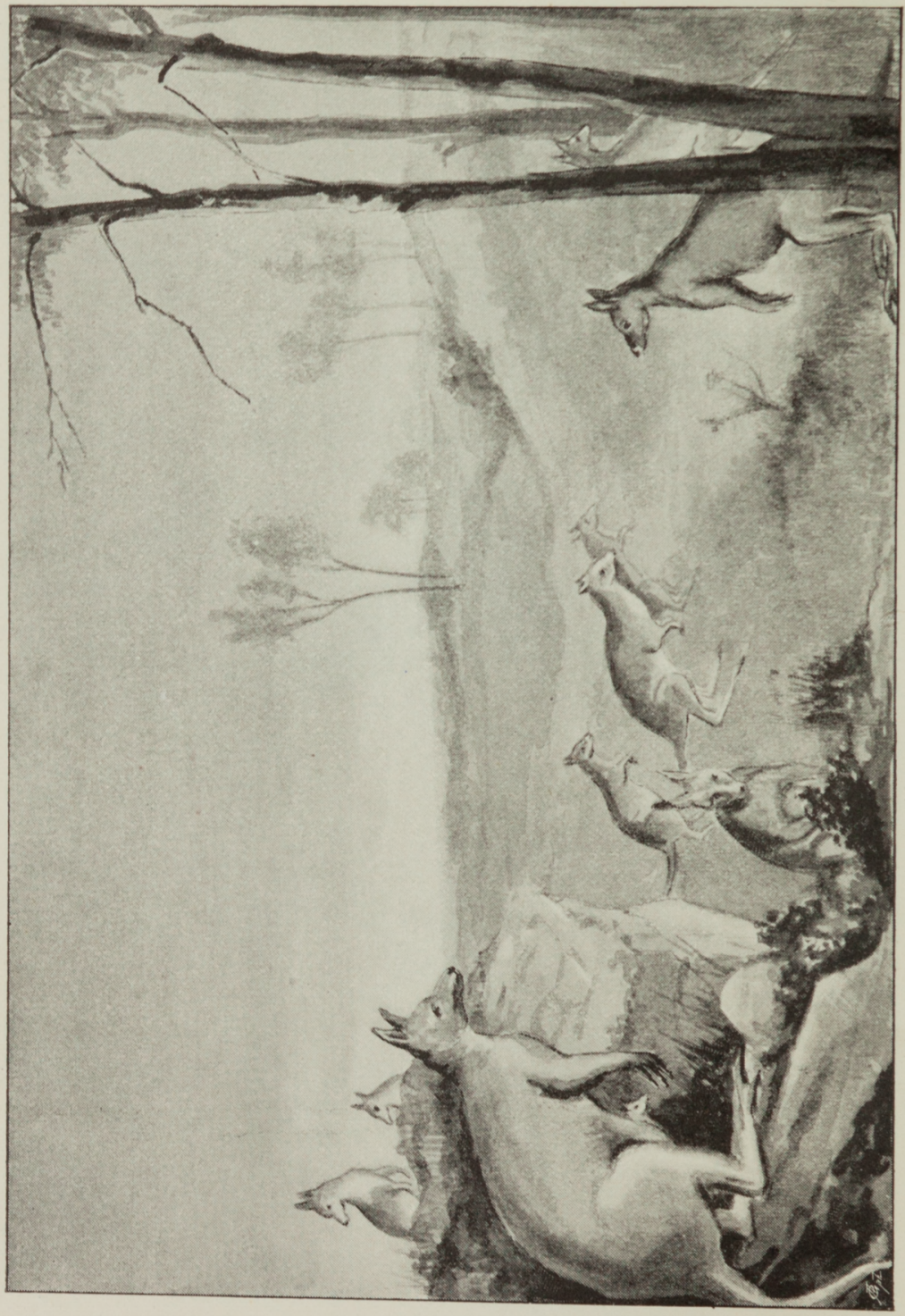

这 


\section{A SKETCH OF}

\section{THE NATURAL HISTORY OF AUSTRALIA}

\section{WITH SOME NOTES ON SPORT}

BY

FREDERICK G. AFLALO, F.R.G.S., F.Z.S., Etc.

AUTHOR OF "SEA-FISHING ON THE ENGLISH COAST"

"HINTS AND WRINKLES ON SEA-FISHING"

\section{ILLUSTRATED BY F. SETH}

"Animals are such agreeable friends-they ask no questions -G. ELIOT

"Wild animals never kill for sport. Man is the only one to whom the torture and death of his fellow creatures is amusing in itself."-FROUDE

\section{Zloñon}

MA CMILAN A N CO, LTD.

NEW YORK: THE MACMILLAN CO. 
Richard Clay and Sons, Limiten, LONDON AND BUNGAY. 


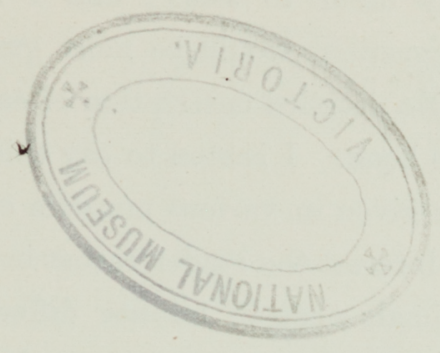

\section{PREFACE}

IT is my wish in the following pages to present the reader with a sketch of the zoology of our Australian colonies. That my little book will be of the slightest service to the scientific world I do not for one moment flatter myself; but there must be humbler workers in every field; and the results of several years' reading and a stay in the colonies may perhaps be of some interest to many who are travelling to those parts and others who are staying at home.

I have not padded the book with lengthy extracts from standard authors, as such a course, while adding to its bulk a desirable hundred pages, would not have been honest to either the reader or the said authors.

In issuing a Colonial Edition, the Publishers have acted, on my advice, given in the hope that many Australians interested in the natural history of their wonderful land may, for the sake of such further editions as may be called for, favour us with any corrections and notes that 
may occur to them; and I need hardly say that such suggestions would be most gratefully received.

No detailed description of each species will be found in the book. I hasten to say this at the outset. Such details are given in various museum catalogues; and I have tried to interest the reader rather in the life-habits of Australian animals than in minute differences in their colouring or dentition, subjects that would be out of place in an unpretentious volume like the present, which is but an introductory handbook.

Consuetudo pro lege! No friends have, as they generally seem to do, begged me to publish this little work. In fact, I have no apology to offer for its appearance, though none the less sensible of its many defects. But I gladly take this opportunity of expressing my thanks to the very courteous curators of the Australian Museums, to the Hon. W. Rothschild, F.Z.S., and his curators, Dr. Hartert and Dr. Jordan, for kindly showing me the private collections at Tring, and to G. A. Boulenger, Esq., F.Z.S., of the British Museum, for some valuable hints regarding the classification of sea-snakes.

Also to those many hospitable colonials who gave me opportunities of seeing much sport, both afield and afloat.

Literary obligations are acknowledged in footnotes and elsewhere in the body of the work.

$$
\text { F. G. A. }
$$

Bournemouth, Juty, 1896. 


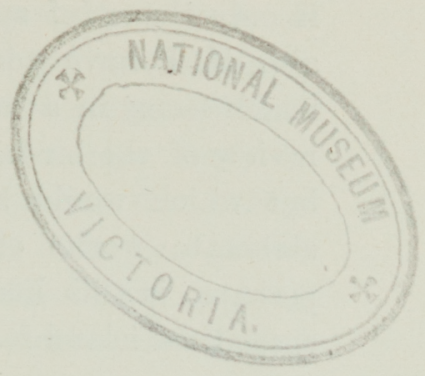

\section{INTRODUCTION}

"Australia stands alone: it possesses no apes or monkeys, no cats or tigers, wolves, bears, or hyenas; no deer or antelopes, sheep or oxen; no elephant, horse, squirrel or rabbit; none, in short, of those familiar types of quadruped which are met with in every other part of the world. Instead of these it has marsupials only, kangaroos and opossums, wombats and the duck-billed Platypus. In birds it is almost as peculiar. It has no woodpeckers and no pheasants, families which exist in every other part of the world, but instead of them it has the mound-making brush-turkeys, the honey-suckers, the cockatoos, and the brush-tongued lories, which are found nowhere else upon the globe."-Alfred Russel Wallace: The Malay Archipelago.

Such was the passage that originally excited my interest, as it doubtless has that of many others, in the natural history of Australia; and I gladly take it as the text on which is based the following collection of notes.

In compressing within the limits of a convenient handbook some account of the fauna of a country covering nearly three million square miles, a vast island with eight 
thousand miles of coast line, some allowance must be craved if only the chief species have been noticed in detail. As also if I have adopted a somewhat easy arrangement, which seems in a measure allowable in a short and rapid review of the birds, beasts, and fishes of a single country, but which would be unpardonable in the preparation of elaborate works of a wider scope. More particularly, perhaps, is this license warranted in the case of a highly specialised island fauna like that treated of in the following pages.

Had this little book been planned on stricter lines, then must not only New Guinea, to the fauna of which some passing allusions will be found, but indeed the Aru Islands, Moluccas, in fact the whole of the Austro-Malayan Archipelago, as Wallace calls it, have been included in its scheme. As this course, however, though unquestionably preferable in many respects, would have inevitably much increased the size of the book, besides carrying me amid scenes with which I was unacquainted, it has been thought preferable to confine its scope to a succinct account of the natural history of the area politically known as the Australian colonies, rather than extend the treatment to the broader zoological region alluded to. The area in question may be seen by a glance at the map, in which figure the principal names that occur in the body of the work.

Perhaps the grotesque animals of Australia are in keeping with its remarkable geography, the absence of great rivers or inland seas; fit children of scenes with a dominant note, as Marcus Clarke said, of "weird melancholy . . . a all fear-inspiring and gloomy."

It cannot be said that we have great reason for congratulating ourselves on the names selected for some of our far-off colonies. Allusion is not here intended to 
the gross neglect that has associated the name of the pioneer Cook with only a small Queensland port, a streamlet debouching on Botany Bay, a political division of New South Wales and a Sydney Municipal Ward. It is rather to the inappropriateness of names implying physical comparison with European countries that exception is taken. It seems ridiculous, for example, that no better name than "New Holland" should for a long time have been found for that hilly, arid country; or that the magnificent mountain and river scenery of the neighbouring colony should still be associated with the unpicturesque island of Zealand. The name of one colony, South Australia, is a barbarism ; for, besides the expression being a tautology, amounting to the "South South Country," the qualification is not even correct, for both the neighbouring colonies extend further south, and its boundaries have since 1863 been extended to the far north. So that the South-Australian Coburg Peninsula (with Port Essington), a most important ornithological district from which Gould obtained a number of his species, faces New Guinea, an anomaly which cannot but strike the student, even if it does not at the outset cause him some confusion. For this vast central colony, having an area not far short of a million square miles and greater than that of any other with the exception of Western Australia, the more appropriate name "Centralia" has been suggested and is already in wide use. The name of "South Australia" would best apply to Victoria, which, besides extending further south than any other colony on the mainland, lies wholly south of the 34 th parallel.

And the zoologist, at any rate, will reasonably find much to object to in the name Australasia, as applied to countries in which the absence (save the doubtful dingo) of all Asiatic types, as well as the survival of a peculiar 
predominating family, the Marsupials, which has long since disappeared from the rest of the Old World-a family in which Dame Nature anticipated for purposes of her own the sporran of the Gael-points to a very long isolation. Even the presence of the only other existing family of marsupials (Didelphys) in the New World is but very slender evidence in favour of any union with South America, since there are abundant marsupial remains in Europe.

The reader will perhaps note with some surprise that the colonies correspond to a greater or less extent with zoological regions; that several important birds for instance, as well as the diamond snake, ${ }^{1}$ occur only in New Sonth Wales. A glance at the map will show that the border of two colonies is frequently marked by a high mountain range or, more rarely, a broad river, both of importance in questions affecting animal distribution, so that, without the analogy being pressed too far, the colonies may roughly be taken as so many divisions of the Australian sub-region. The island of Tasmania has, for instance, as might be expected, a more clearly defined fauna than any of the rest. Here we find no dingo or emu, no rock-wallabies, koala or flying phalangers; but on the other hand there are the only large carnivora, the "tiger" and "devil," and there are further such types as the sooty phalanger, Gunn's bandicoot, Bennett's kangaroo, the hairy echidna, the thick-tailed Dromicia, a rat-kangaroo and a wombat, none of which occur on the mainland.

In calling the reader's attention to the peculiarities of Australian natural history, it may be remarked that no one, acquainted or otherwise with the elements of animal distribution, can fail to be struck with the remarkable

1 This species has been considered by more recent authorities as a variety only of the widely distributed Carpet-Snake (p. 165). 
beasts and birds, more especially with which we are to concern ourselves. Who, for instance, is there but must feel surprise at the absence of monkeys and woodpeckers from its vast forests; or at the presence there, and there only, of the platypus among the lower mammals, the lories among birds, the double-breathing ceratodus among fish!

In Australia, in fact, as a lecturer said recently, we have the strange case of a fossil continent, a land which, long since cut off from the rest of the earth, has developed certain types of plants and animals peculiarly its own; a country that has now reached a stage of development at which, roughly speaking, Europe had already arrived centuries ago. "Advance, Australia!" is the national motto; and it is high time that the continent should make up for lost epochs, and go ahead in good earnest. As for the disappearance of those very remarkable birds and quadrupeds that still distinguish it from more progressive lands, that will soon be an accomplished fact, for cheap firearms and mischievous pot-hunters have already made more impression on its fauna in a decade than would without their agency have been brought about in ten centuries.

As a result of its long isolation, we find that the mammals of Australia belong for the most part to a low type that has disappeared from elsewhere. The claims of the marsupials to the rank of a distinct order are, notwithstanding the apparent identity between their teeth and those of corresponding groups of placental mammals, too great to admit of hesitation in treating them separately, and rest chiefly on the absence of corpus callosum between the hemispheres of the brain, as well as on the almost embryonic state in which the young are born.

These are the real features that at once mark off these 
animals as a class apart. The pouch is an uncertain badge, and in some cases it is represented only by a fold of hair ; in a few, indeed, it is wanting altogether.

The only exceptions to the rule are the doubtful dingo, a few bats, and one family (Mus) of rodents, besides, of course, such aquatic mammals as the dugong, two or three whales, and three seals.

The Dingo, already alluded to, is generally supposed to be a comparatively recent arrival from Southern Asia, a theory that derives some additional weight from the discovery in the South of India of a weapon designed and used on the same principle as the famous boomerang. The bats might, it has been suggested, have flown viâ the Malay Archipelago; the rodents might likewise have reached the country in the canoes of early Malay settlers.

The occurrence of the true opossums (Didelphys) although, as above mentioned, but little argument in favour of recent land-connection between Australia and South America, yet makes confusion worse confounded, and, indeed, opens a wealth of fascinating complicationswhich, however, for want of space, must needs be left to the speculation of the reader. It is only necessary to mention here, in explanation of the term just used, "true opossums," that the Australian phalangers are not opossums at all, though so called by the colonists. The animals of the bush have, in fact, been treated in the matter of popular, or trivial, names as carelessly as the countries they inhabit. Indeed, it is impossible to speak a dozen words in colonial parlance without coming across some instance of this singular abuse of terms.

What, for example, could less convey to home readers the idea of "bush" than a succession of vast forests, few trees standing less than 100 feet, not a branch for the first half of the stem, and no sign of undergrowth! 
So it is with the animals. The "Bandicoots" (Percmeles), for instance, have no connection whatever with the Indian rat (Mus giganteus) of that name. The KangarooHares and Kangaroo-Rats, not being rodents, should, if such superficial resemblances must be traced, have been called Hare- and Rat-Kangaroos. In a too popular nomenclature lies a considerable element of danger. If, as a case in point, I were in the course of the following pages to introduce Australian quadrupeds as so many pouched bears, badgers, ant-eaters, cats, wolves, moles, squirrels, the reader would, subsequent explanations notwithstanding, close the book under the firm impression that, with the trifling addition of a pouch, the Koala is a bear and the Tapoa-tafa a rodent.

The same risk of misconception is incurred by those writers who yield to the temptation of giving novel instances of Australia's so-called " topsy-turvydom," that is, from our point of view. The bees, they say, have no sting, the birds no song, the flowers no scent, the fruits no flavour; the animals bear their young outside; the sun travels the urong way round to its resting place; the cuckoo builds its own nest and sings all night; the cherry grows inside its own stone; the oysters grow on trees and feed on whelks; the trees shed their bark, not their leaves, dc., dc., in all of which statements colonials will recognise a modicum of truth with a considerable leavening of the reverse. And the further explanation necessary to leave the correct impression is generally withheld lest the interest should be thereby diminished. It should have been added, for instance, to these examples of this nefarious practice, which are all quoted from current works of travel or other fiction, that some of the birds sing remarkably well, some flowers are sweet-smelling, some fruits of agreeable flavour, though of the majority in each 
case the verdict is unquestionably a just one. The animals do not bear their young in the pouch, but convey them to that convenient receptacle immediately after birth. In the southern hemisphere the sun naturally travels north of the spectator at mid-day, but this is not the wrong way; there are both parasitic and nest-building cuckoos in Australia, and the so-called "night cuckoo" is an owl. The "native cherry" is no true cherry, any more than the quandong is a peach. The oysters attach themselves, it is true, to the lateral offshoots of the mangrove, but to say that they grow on trees would imply a vegetable nature; and they do not feed on whelks, although the death of the whelk generally results from the oyster's habit of adhering to its back for purposes of locomotion. Finally, while the bark, and not the leaves, of Australian trees is deciduous, it is the thin, outer bark only, and not the entire covering that peels off.

If the Marsupials are a very low type of mammal, then are the Monotremes so much lower that I should almost have preferred classing them by themselves-a course that would, however, have been condemned in a little book of this nature as an unwarranted liberty. I have therefore left these bird-like, cool-blooded creatures under the heading of mammals.

In the bird-world, Australia also surprises the visitor. It is in the case of birds, gifted as they are with such wonderful powers of flight, that the rigid principles of distribution-the indefinable "Thus far and no further" which confines them with invisible bars in certain zoological provinces-are most difficult to understand. We shall not feel much surprised at finding in New Zealand, for instance, nearly twenty species of wingless birds, surviving relatives of that feathered giraffe, the extinct Moa. The land of the Maori is an isolated island that has doubtless had ample time to develop such comicalities; but 
what must surprise us is that the twelve hundred miles of ocean should never be traversed by the stronger-winged among the Australian birds, though in the matter of temperature, the difference from the southern colonies is not marked, while, so far as food is concerned, New Zealand furnishes, if no mammals for the owls and eagles, at least abundance of fruits and insects for the rest. Nor will it escape comment that so large a proportion as two-thirds of the seven hundred species of Australian birds should, roughly speaking, be found nowhere else; that here only we encounter the brush-tongued lories, the honeysuckers, and the cockatoos; and that, on the other hand, no wagtail should run beside its rivers, no lark pour forth melody from its heavens, no woodpecker press its fanshaped tail against the grub-sheltering bark of its superb trees.

The Reptiles also present some peculiarities when compared with those of other lands.

Of its snakes, which are varied and numerous, by far the greater number-including the sea-snakes en bloc-are venomous, though not necessarily dangerous to mankind; and in one colony, South Australia I think it is, the proportion these bear to the harmless species is as six to one !

Toads there are, but not one of the true (Bufo) genus; tree-frogs in plenty; only one Rana, or true frog.

The fish, characterised by brilliant colouring, large and sharp teeth, and liberal development of spinal processes, which render it a very difficult matter to handle them with immunity, present many points of great interest to the angler-naturalist, although their collective value for table purposes is not high. The lung-fishes (Dipnoi) of Queensland are of course the most interesting from a scientific point of view, as throwing considerable light on the 
position of Australia in respect of the other continents in the rivers of which these double-breathing fishes occur.

Even in the lowly insects, which, for all their want of backbone, force their more striking peculiarities on the "new-chum" at a very early stage of his colonial experience, this remarkable country offers some curiosities which are alluded to very briefly in the appendix. There is, for example, a flea of threatening aspect that cannot jump, but fortunately it has no love for man.

Indeed, throughout its world of life, not excepting its fast-disappearing aboriginals, which are by courtesy placed at the head of its natural productions, Australia is par excellence the land of striking anomalies. With that unfortunate race who, while they pass much of their existence in puris naturatibus without clothes or domicile of any description, could yet invent a weapon like the boomerang, ${ }^{1}$ their performances with which verge, as I have witnessed, on the miraculous, we have not to concern ourselves. Their knell is tolling even now, and almost with the close of the present century, killed off the face of the earth by a process known as Civilisation, a process stealthier and more relentless than any "Black War," they will be at rest with their extinct Tasmanian brethren.

It is not, then, to be wondered at that the natural history of Australia presents problems and features of an interest all the keener that so many districts are even to-day

${ }^{1}$ Bennett, in his Wanderings in New South Wales (i. p. 116), quotes from the United Service Journal an interesting account of the construction and use of this wonderful weapon, the principle of which is evident to anyone who can make a hoop return to its startingpoint. 
unsatisfactorily explored that may yet yield a wealth of forms new to science.

With much to learn, and still more perhaps to unlearn, the subject is one likely to attract increasing attention in the colonies themselves, both among the more learned societies and among the rising generation in general. For us at home, I hope it may not be said in a few years' time that we ignored the value and interest of Australia until we had lost it. I shall be glad, no one more so, if my prophetic instinct is at fault.

But in any case, the number of readers interested in Australian beasts and birds is increasing every year; and I trust that both the critic and reader will do me the kindness to recollect that this little handbook is intended only as affording a bird's-eye view of the subject, an introduction and encouragement to the study of the magnificent works of Gould, which are, however, beyond the means of the great majority, who have not perhaps the time or inclination to study them at the national libraries, both at home and in the colonial capitals.

And that there is still room for such an unpretentious account of the Australian fauna as shall appeal to the general reader and correct some erroneous impressions left by popular writers, I think the following quotations from the pens of the Rev. J. G. Wood and his son go far to indicate :-

The former gentleman (Handy Natural History, 1886), says: "In fact in that continent all the really indigenous animals are marsupials."

And in his Nature and her Servants (1886), the Rev. Theodore Wood says: "With one single exception (the dingo) no mammals belonging to any other group are found in any other part of Australia. In the whole of 
that vast continent there are neither monkeys nor bats, nor beasts of prey, nor insect-eaters, nor bears, nor deer, nor rodents."

The italies are my own. In the first portion of the book will be found descriptions of bats, beasts of prey, insecteaters and rodents.

Thirty families of Australian Vertebrates, or nearly a quarter of the whole, are found nowhere outside the region. 


\section{TABLE OF CONTENTS}

\section{VERTEBRATES}

\section{MAMMALS}

PART I. -PLACENTALS

Chap. I. The Dingo (Canis dingo) . . . . . . . . . 3

" II. The Rodents (Mus vellerosus, Hapalotis, Hydromys, \&c.) . . . . . . . . . . . . . . . 8

, III. The Bats (Chiroptera) . . . . . . . . . . . . . . 13

", IV. The Dugong (Halicore) . . . . . . . . . . . . . 17

,, V. The Whales (Cetacea) . . . . . . . . . . . 20

,, VI. The Seals $($ Phoce $)$. . . . . . . . . . . . . . . 24

PART II.-MARSUPIALS

INTRODUCTORY . . . . . . . . . . . . . . . . . 26

Chap. I. The Macropods (Kangaroos, Wallabies, Hare-

Kangaroos, \&c.) . . . . . . . . . . . 32

, II. The Phalangers ("Opossums," Koala, Flying-

Squirrels, Opossum-Mouse, Cuscus, \&c.) . . . 48

„, III. The Wombats (Phascolomys) _. . . . . . . . 59

", IV. The "Bandicoots" (Perameles) . . . . . . . . 63

"V. The Dasyures(Tasmanian "Wolf" and "Devil,"

"Native Cats," Pouched Mice, Myrmecobius . 65

"VI. The Pouched Mole (Notoryctes) . . . . . . . 72 


\section{PART III.-MONO'TREMES}

INTRODUCTORY . . . . . . . . . . . . . . . . . . . . . . 73

Chap. I. The Duck-billed Platypus (Ornithorhynchus paradoxus) . . . . . . . . . . . . 75

„, II. The Echidnas (Echidna hystrix; E. setosa) . . . . 79

\section{BIRDS}

INTRODCCTORY .

\section{PART I.-WATERFOWL}

1. Sea Birds : Albatross and Petrels, Gulls and Terns, Pelicans and Gannets, Penguins . . . . . . . . . . . 89

2. Ducks and Geese: Black Swan, Semi-palmated and Cape Barron Geese, Musk and Pink-Eyed Ducks, \&c. . . . .

\section{PART II.-WADING BIRDS}

1. Herons, Bitterns, and Rails: Nankeen Night-Heron, Bitterns, Chestnut-bellied Rail, "Native Hen," “Moor Hen" . . . . . . . . . . . . . . . . . . . 101

2. Smaller Waders: Plovers and Dottrels, "Alarm Bird," Ibises, Stilts, Whimbrels, \&c. . . . . . . . . 102

3. Struthious Birds: Emu, Cassowary, Bustard, Jabiru and Native Companion 104

\section{PART III.-PERCHING BIRDS}

1. The Kingfishers . . . . . . . . . . . . . . . . 113

2. The Honey-Eaters . . . . . . . . . . . . 117

3. The Parrots and Parrakeets . . . . . . . . . 124

4. The Moreporks . . . . . . . . . . . . . . . . . . . . . . . . . 126

5. The Swifts and Swallows . . . . . . . . . . . . 128

6. The Wood-Swallows . . . . . . . . . . . 129 
7. The Lyre-Birds . . . . . . . . . . . . . . . . . . 129

8. The Bower-builders . . . . . . . . . . . 132

9. The Cuckoos . . . . . . . . . . . . . . 135

10. The Wrens and Warblers . . . . . . . 135

11. The Diamond Birds . . . . . . . . . . . . 137

12. The Rifle Birds . . . . . . . . . . . . . . . 137

13. The Finches . . . . . . . . . . . . . . . . 138

14. The Flycatchers . . . . . . . . . . . . . . . 139

15. The Shrikes . . . . . . . . . . . . . . . 140

16. The Robins . . . . . . . . . . . . . 140

PART IV.-BIRDS OF PREY

1. Eagles . . . . . . . . . . . . 142

2. Hawks and Kites . . . . . . . . . . . . 144

3. Owls . . . . . . . . . . 146

PART V.-SCRATCHERS

1. Pigeons . . . . . . . . . . . 147

2. Brush Turkeys . . . . . . . . . . . . . 154

\section{REPTILES}

INTRODUCTORY

PART I.-SNAKES . . . . . 159

1. Harmless Snakes . . . . . . . . . . . 165

2. Venomous Snakes . . . . . . . . . . 168

3. Water Snakes . . . . . . . . . . . 173

PART II.-LIZARDS . . . . . . . 177

PART III.-CROCODILES . . . . . . 186 


\section{BATRACHIANS}

Frogs and Toads

\section{FISHES}

INTRODUCTORY

Part I.-ANGLING . . . . . 201

PART II.-FRESH-WATER FISH . . . . . 213

PART III.-SEA FISH

1. Sharks and Rays ........ . . . . . . 220

2. Perches . . . . . . . . . . . . . 224

3. Breams . . . . . . . . . . . . . . 225

4. Sea-Scorpions . . . . . . . . . . . . . . . . 227

5. Frog-Fish . . . . . . . . . . . . . . 228

6. Mackerels . . . . . . . . . . . . . . . . . . 229

7. Horse Mackerels . . . . . . . . . . . . . . . . . 230

8. Mullets . . . . . . . . . . . . . . . . . 232

9. Jewfish and Traglin . . . . . . . . . . . 233

10. Barracoutas . . . . . . . . . . . 234

11. Trumpeters . . . . . . . . . . . . . . . 234

12. Nannygai . . . . . . . . . . . . . . . . 235

13. Morwong . . . . . . . . . . . . . 236

14. Flatheads . . . . . . . . . . 236

15. Wrasses . . . . . . . . . . . . 237

16. Flatfish . . . . . . . . . . . 238

17. Beardie or Ling . . . . . . . . . . . . . 240

18. Catfish . . . . . . . . . . . . . . . 241

19. Herrings . . . . . . . . . . . . . . . 241

20. Sergeant Baker . . . . . . . . . . . . . . . . . . 242

21. Garfish, Long-Tom, and Flying Fish . . . . . . . . 243

22. Eels . . . . . . . . . . . . . . . . . . . . 246 
23. Leatherjackets, Coffer-Fish, and Toad-Fish . . . 246

24. Sea Horses . . . . . . . . . . . . . . . . 247

25. Lampreys . . . . . . . . . . . . . . . . 247

26. Mud-Hoppers . . . . . . . . . . . . . . . . . 248

Australian Fisheries . . . . . . . . . . . . 248

\section{APPENDIX}

\section{THE INVERTEBRATES}

I. The Molluscs _ . . . . . . . 258

II. Insects . . . . . . 261

III. Spiders and Scorpions _. $\quad 276$

IV. Centipedes . . . . . . . . . . . . . $\quad 276$

V. Crustaceans . . . . . . . 277

VI. The Ground Floor . . . . . . . . . . 278

GLossary . . . . . . . . . . . . . . . . . . 283

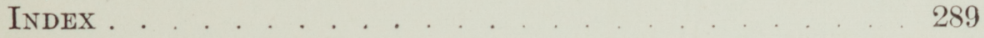





\section{LIST OF ILLUSTRATIONS}

PAGE

KANGAROOS Frontispiece

Dingons . . . . . . . . . . . . . . 4

Tree Kangaroo . . . . . . . . . . . . . . . . . . . . 33

Brush-talled Opossum . . . . . . . . . . . . . . . 49

KoAlA . . . . . . . . . . . . 52

Flyting Squirrel . . . . . . . . . . . . . . 55

Wombat. . . . . . . . . . . . . . . 60

Thylacine. . . . . . . . . . . . . . . . . . 66

Platypus . . . . . . . . . . . . 76

Penguins . . . . . . . . . . . . . . . . . . . 97

The Eмu . . . . . . . . . . . . . . . . . . 105

Native Companion . . . . . . . . . . . . 111

LAUghing Jackass . . . . . . . . . . . . . . . 115

Lyre Bird . . . . . . . . . . . . . . . 130

SATIN BOWER-BIRD. . . . . . . . . . . . . 133

Brush Turkey . . . . . . . . . . . . . . 151

SchNAPPER . . . . . . . . . . . . . . 202

Morwong . . . . . . . . . . . . . . 205

Black BreaM ... . . . . . . . . . . 207

Drummer . . . . . . . . . . . . . . . . . . . 226

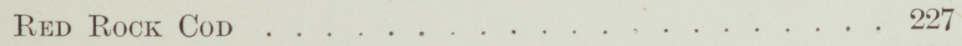

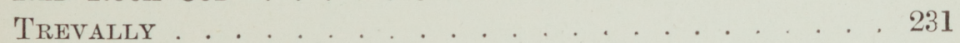

NANnYgat . . . . . . . . . . . . . . . . 235

Flathead . . . . . . . . . . . . . . 236

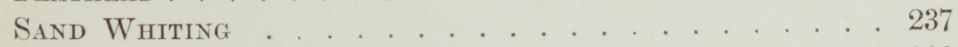

SOLE . . . . . . . . . . . . . . . . . . 239

Sergeant Baker . . . . . . . . . . . . . . . 242

Silver Fish. . . . . . . . . . . . . . . 274

Praying Mantis. . . . . . . . . . . . . . . . 275

SEA SLUG . . . . . . . . . . . . . . . . . . . . 278

Physalia . . . . . . . . . . . . . . . . . . 280 


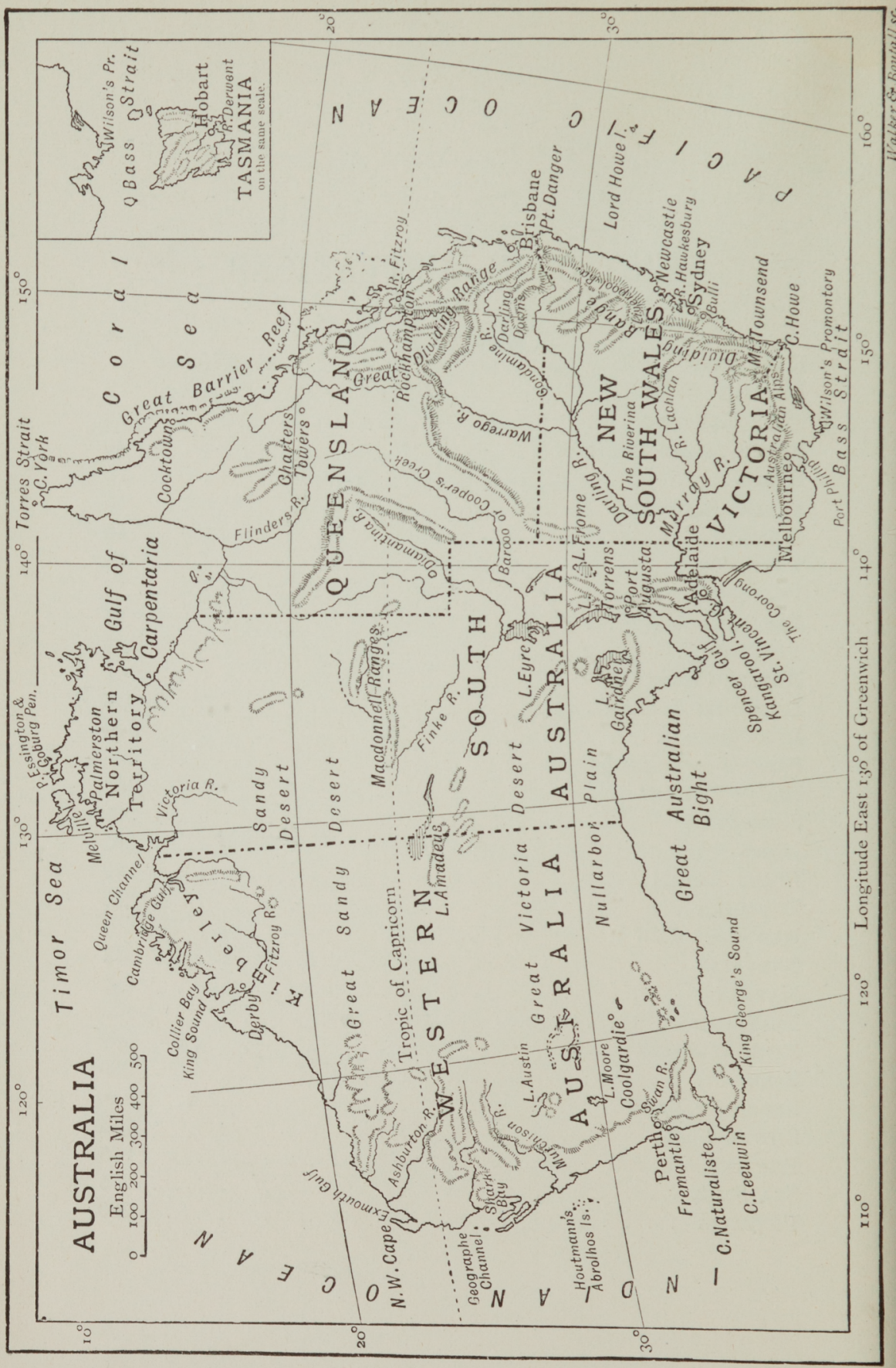


MAMMALS 



\section{Part I -PLACENTALS}

\section{CHAPTER I}

\section{THE DINGO}

Allusion was made in the Introduction to the higher mammals of the Australian continent, which, in the presence of the more numerous and interesting marsupials, are apt to be overlooked, especially by the visitor. In every other part of the world, one or two districts in North and South America excepted, all mammals are placental, ${ }^{1}$ and it is not therefore surprising that the attention of naturalists visiting the Australian region should have centred on those remarkable lower types which I shall consider in subsequent chapters. We must not, however, overlook the higher types, rather over sixty in number, although, with the exception of the dugong and whales, marine forms, they are, like the marsupials, of little use to the white man.

And to follow the orthodox arrangement, from highest to lowest, it will be necessary to take these first, commencing with perhaps the highest type of all, the Dingo.

1 See Glossary. 
There is certainly nothing very prepossessing about this half-wild companion of the aboriginal that one should class it as a higher type; but, zoologically speaking, the fact remains that, if indigenous, which many doubt, the dingo is the highest Australian animal, a fact highly characteristic

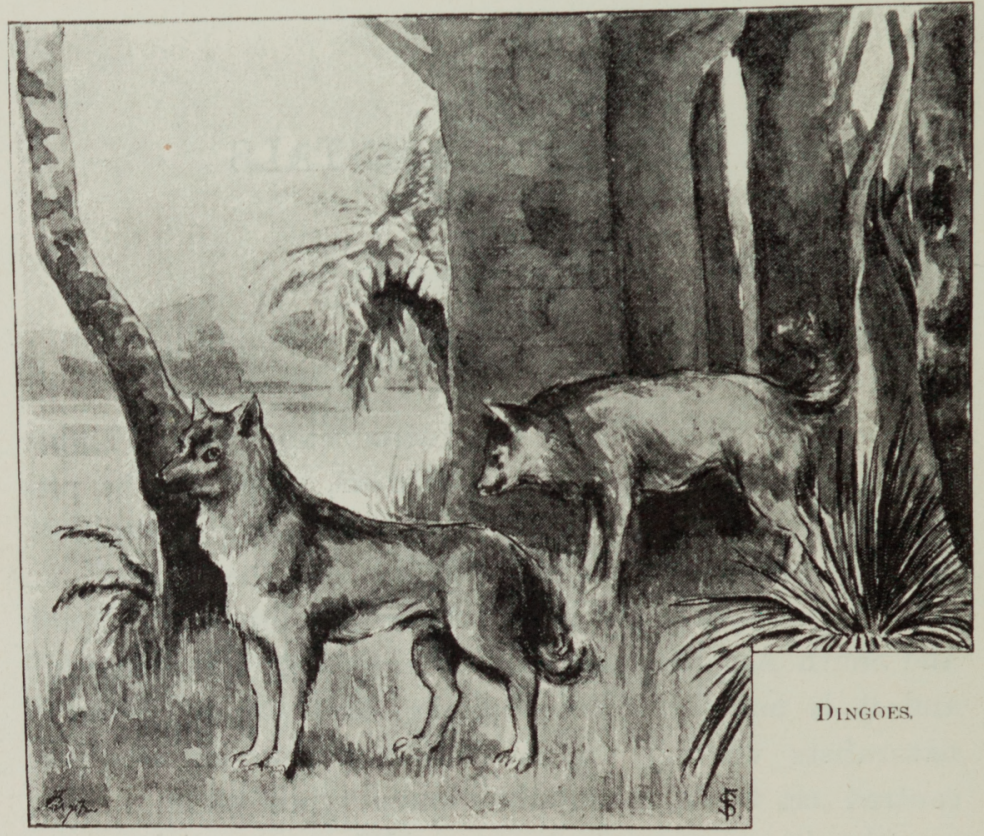

of the backward fauna of that stationary region. Australia is the China of zoology.

Well, the dingo ${ }^{1}$ is the wild dog of that land, and is found nowhere else, not even in the island of Tasmania, where its place is taken, so far as the unfortunate sheep

${ }^{1}$ Dingo was the name applied by the aboriginals to the settlers' dogs. Their own dogs they called Warrigal, but the colonists call them by the former name. 
are concerned, by the equally ferocious and destructive marsupial carnivora, the "Wolf" and "Devil." Having three (and not two) pairs of molars in the lower jaw, it is the only true wild-dog, differing from all Asiatic breeds. It lives in perfect savagery, save where half-domesticated by the blacks, who steal the pups and give them over to their "gins" to nurse. Some travellers have even asserted that these unfortunate females have, at the bidding of their lords, killed their own offspring in order to better rear the more useful pups; but others deny this.

They grow to about the size of a wolf and vary considerably in the matter of colour. Visitors to the Zoological Gardens may have noticed a very handsome pair of dingoes in the cages in front of the lion-house, their coat being reddish-brown. I have also seen them gray and almost black, and indeed these well-cared-for captives are much more pleasing to look upon than the tousled mongrels one encounters skulking at the heel of the black boy. Though for ever quarrelling with the English dogs on the stations, they breed pretty freely together, the native dog, which has only a dismal howl of its own, soon acquiring a feeble bark from its more civilised companions.

Like its aboriginal master, it has been somewhat freely "dispersed" by the settler, until it is now getting scarce in many districts, where baits impregnated with strychnine have done their work well. The result of its disappearance from the cleared country has been a plague of kangaroos, which have in turn to be thinned by organised "drives." If the farmers at home could but get a glimpse of the thankless fight which their Australian competitors have to maintain against dingoes, kangaroos, rabbits, cockatoos, injurious caterpillars, drought and inundations, they might bear with their own troubles a little more patiently.

Every man's hand is against this cowardly larrikin of 
the brute world, relentless despoiler of the sheepfold, through which it will run amuck, killing a number of animals by eating out the paunch, its favourite monthful. Clever as the fox at feigning death, it is said that these animals have not moved a muscle until partially flayed; and old bush hands have learnt to make quite sure, in cases where there is any doubt, by cutting the throat. Unlike other dogs, it rarely hunts in packs.

The distribution of the dingo is, as already said, limited to Australia. In Tasmania it does not occur, so that it seems more than likely that the lean dogs formerly spoken of in connection with the now extinct aboriginals of that island were purchased, or otherwise acquired, of the early settlers.

Reference has been made above to the doubts concerning the origin of this animal in Australia. There seems some reason, although the present tendency among the professors of that country is decidedly to regard it as indigenous, to believe that so large a placental, standing alone among the marsupials and little rats and bats, must owe its introduction to early Malay settlers from Asia.

In fact, this wild $\operatorname{dog}$ holds a position in that isolated continent not unlike that of the well known Barbary Ape (Macacus inuus) in Europe. As the same species occurs in the Atlas range fringing the opposite coast, many have considered it not strictly indigenous, but of early introduction by man, an admissible theory when we consider the short distance and the constant traffic between the two coasts in historic times.

Mr. Lydekker says that dingo remains have been found in river gravels where no human bones are found, though in the cave relics they invariably lie together. Were this all, we should be inclined to accept the dingo's priority. Mr. Wallace, ${ }^{1}$ on the other hand, points out the very early 
presence of man in Australia, as evidenced by a fragment of stone axe which was found about five feet below the surface imbedded beneath the gravel drift, or "cement," of a gold mine in the colony of Victoria.

So far it would seem that no evidence is forthcoming of sufficient weight to set the question at rest, and hence many prefer, pending some unanswerable solution, to look upon the dingo as an Asiatic importation. Save that it is in some districts made a substitute for the fox to furnish sport, the creature has never been put to any use whatever by the settlers. Even the black fellow only succeeded in raising it to a half-domesticated state, and it was liable at any moment to run wild again. Whether owing to illtreatment or more natural causes, this animal seems to lack all the nobler traits of the dog, being even lower in its morals than the pariah of Indian villages. It is the only true wild dog in the world, and Mr. Hudson ${ }^{2}$ compares it to the aguard of South America.

1 Island Life, p. 47, footnote.

2 Naturalist in La Plata. 


\section{CHAPTER II \\ THE RODENTS}

InsigrifiCant as they are in size, these little creatures, characterised by the usual pair of ever-growing incisors in either jaw, have in Australia a special interest for the naturalist, as they include the only true Water Rats (Hydromys), a title to which our water voles are but pretenders.

With the so-called Pouched Rats, hereinafter described, these true rodents have, strictly speaking, nothing in common, though the external resemblance is striking, as may be seen by a glance at the frontispiece of Murray's Geographical Distribution of the Mammals, a book to which I have been much indebted in the preparation of the present work.

Among those who prefer to regard the Australian mammals as almost exclusively marsupial, the presence of these rodents at the antipodes has, as in the case of the dingo, given rise to some doubt as to their origin and history. More especially is this the case with the fruiteating "Maori" rat of New Zealand, which, the natives aver, is fast disappearing before the fiercer brown rat from Europe, which they call "pakeha," or the stranger. 
So the same game of survival and extinction seems playing itself out in the brute-world as with the human races, the east disappearing before the new blood from the west.

Many doubted for a long while, and some do so still, the existence of this indigenous New Zealand rat, but the evidence of its origin is much stronger than that on which the dingo is reckoned among Australian quadrupeds.

It will now be necessary to enumerate briefly the chief Australian species. They all belong to one family, Mus.

Hapalotis is a well represented genus, all the members of which, excepting a Queensland species, $H$. conditor, have a long and pencilled tail which is usually white throughout the lower half. They have a weakness for sweet things, and do not hesitate to belp themselves from the settlers' larders - a little way rats and mice have all the world over. The following are of this genus.

II. albipes, or the Rabbit Rat, ${ }^{1}$ is nowhere very abundant, though it occurs throughout the southern colonies. Gould is of opinion that the rarity of this species is more apparent than real, arising from its semi-nocturnal habits. The tail is exceptionally long and prehensile.

$H$. apicalis, the White-tipped Rat, is a native of South Australia, and is distinguished by its white chest and feet.

II. hemileucura, a species with very coarse, hairy fur.

$H$. hirsutus, a species described from Port Essington in the far north, has a long hairy tail.

H. penicillata may, according to Mr. Gilbert, ${ }^{2}$ be seen running about the beach among the casuarinas. I saw something that might have answered to the description darting among the mangroves in Keppel Bay, but they were too shy to observe properly, even to shoot.

1 A name likewise applied to Peragale lagotis.

2 Gould: The Mammals of A ustralia. 
II. conditor, a North Queensland species, has longer ears and more developed hind-feet than the rest, and lacks their pencilled tail. It constructs a large yet compact nest of small sticks.

H. cervinus is, so at least one would judge by museum specimens, by far the most graceful and agile of these jerboa-like rodents, a surmise fully borne out by those who have observed it in its native deserts. It is probably able to subsist without water longer than the majority of rats, which are, in fact, a particularly thirsty race.

H. murinus is a little mouse-like rat of South Australia.

$H$. longicaudatus and H. mitchellii come from the Swan River district.

The second genus is Mus.

Mus longipilis is a species from the Victoria River disrict, and can be at once recognised from the long black hair with which it is covered. It is to be found in the Sydney Museum, but was not, I think, at South Kensington when I last looked round the cases.

M. cervinipes, the Buff-footed Rat, is common enough in the eastern scrub generally, and particularly so among the flats and islands of the Brisbane River. The Queensland blacks call it Corrill, and eat it, as they do most else.

M. assimilis, known as the Allied Rat, is met with in all Southern colonies.

M. manicatus, a Port Essington species, has white feet and belly.

A number of species (especially the white-footed $M$. gouldi) are extremely sociable, several families sharing one large nest. This arrangement is much appreciated by snakes, which make terrible raids on these little colonies.

Their distribution also differs considerably. For instance, $M$. nanus, the Little Rat, is found in all the 
colonies, but $M$. albocinereus, a species in which Gould notices the wonderful protective colouring, occurs only in Western Australia.

M. nove hollandice is also very widely distributed.

Mention must now be made of the true Water Rats, or Beaver Rats as they are called. As in Hapalotis, the lower portion of the tail is pure white, and the hind-feet are webbed. Beyond the fact of their being, as already stated, true water-rats (not voles), they possess little of interest.

Among them are

Hydromys chrysogaster, named by St. Hilaire, and found in New South Wales and Tasmania.

$H$. fulvolavatus, found in the large "waterholes" 1 of South Australia.

H. leucogaster occurs in New South Wales, while in Western Australia we find 1 . fuliginosus, or the Sooty Water Rat.

\section{RODENTS}

The White-footed Tree Rat . Hapalotis albipes (N. S. W.) ${ }^{2}$

, White-tipped ,, , . H. apicalis (N. S. W.)

. Black-tipped ,, ,, . H. penicillata (N. A.)

, Great ,, ,, . II. hirsutus (N. A.)

, Building ,, ,, . H. conditor (N. A.)

,Mouse-like ," ,, .H. murinus

,, Spotted-tailed ,, ,, . H. macropus

", Long-tailed , ,, .H. longicaudatus

1 A "waterhole," a typical feature of Australian landscape, is a lake, sometimes of great size and some depth, which in the dry season may become marsh or even dry land.

2 The initials denoting colonies or localities given in this and subsequent lists are not intended to denote that the species is found only in the colony indicated. In some cases, indeed, they mean little more than that Museum specimens were thus labelled. 
Mitchell's Tree Rat . . H. mitchellii

The Buff ," , ... H. cervinus

H. arboricola

H. hemileucura (N. A.)

"Dusky-footed Rat. . Mus fuscipes (Southern colonies)

", Tawny ,, . . M. vellerosus (S. A.)

,, Long-haired ,, . . . M. longipitis

„, Buff-footed ,, . . . M. cervinipes (N.S.W. and Q.)

," White-footed , . . . M. manicatus (Coburg P.)

"Allied , . . . M. assimilis (W. A.)

"Sordid ", . . . M. sordidus (N. S. W.)

„, Plain ,, . . M. lineolatus (Q.)

Gould's

'The Little

$$
\text { , . . . M. gouldi (W. A.) }
$$

,Greyish-White ,, . . . M. albocinereus (W. A.)

„, Delicate " . . . M. delicatulus (Coburg P.)

„, Field Mouse . . . . M. nova hollandice (N.S. W., S. A.)

Water-, or Beaver Rats.

(General in Australia and Tasmania)

Hydromys chrysogaster H. fulvolavatus

H. leucogaster

H. fuliginosus

II. lutrillus 


\section{CHAPTER III}

\section{THE BATS}

THese curious, mouse-like, winged creatures abound all the world over, where the proper food is supplied, fruit for the Flying Foxes, insects for the rest; and Australia is no exception. If they are scarce in Tasmania, it is for the same reason as excludes them from Iceland, St. Helena, the Galapagos group, and some few other islands where they are either rare visitants or wanting altogether. No insects, no bats.

It is somewhat remarkable that the great Kalongs, abundant on the south coast, should, not ere this have discovered the orchards planted in Tasmania by the settlers.

Australian bats, which are of some two dozen species, are not more interesting than are those of their kind in other parts of the world, so that a brief mention of the typical kinds will be sufficient.

\section{i. Fruit-eating Bats, Kalongs, or Flying Foxes.}

The Great Grey-Headed Kalong (Pteropus poliocephalus) is an inveterate despoiler of the peach orchards of New South Wales. Bennett mentions having seen numbers forty years ago in the Sydney Botanic Gardens, a sight 
which would certainly invite comment nowadays. So strong is the fotid odour of this creature, that peaches just brushed by its wings are rendered unfit for the market. Yet not even its smell can protect it from the all-devouring blacks.

P. conspicillatus, which occurs on Fitzroy Island (E. coast), has powerful teeth with which, if given the chance, it bites freely. The eyes and shoulders are encircled by broad bands of orange-coloured fur, which give this species a pretty appearance.

$P$. funereus, found on the north coast and, if we may believe Temminck, distributed throughout the Malay Archipelago, feeds largely on blossoms, a delicate diet that does not, however, free it from the family failing. I have smelt these bats even before I saw the boughs of the flowering trees bending under the weight of their dark bodies.

\section{ii. Insect-eating Bats.}

Molossus austratis is a large species with a curious throatpouch. The wing membrane is almost transparent, and the fur is brown edged with white, the large ears being conspicuously black.

Megaderma gigas, allied to the blood-sucking $M$. lyra of India, is dark green above and white below, with pink wings and nose-leaf.

Rhinolophus megaphyllus, the Great-eared Horseshoe-Bat, is the largest of the horseshoe-bats, and has a very large nose-leaf.

The Orange-coloured Horseshoe-Bat ( $R$. aurantius) is a beautiful little bat with black wings and ears.

Of the Long-eared Bats, we have Nyctophilus geoffroyi, common in the neighbourhood of Perth (W.A.), as is also 
N. timoriensis, concerning which Gould ${ }^{1}$ alludes to a doubt as to whether it is found, as the specific name would imply, in the island of Timor.

The Short-eared Bats are some half-a-dozen in number, the principal being -

Scotophilus gouldi, a New South Wales species, with black fur and wings of pale brown.

$S$. morio, a chocolate species, very common in New South Wales, and remarkable for the great height at which it usually flits.

The Small-toothed kind ( $S$. microdon), is somewhat larger than our Pipistrelle, which it otherwise greatly resembles.

S. picatus is a rare and beautiful little bat, the fur being of a glossy black, edged with white, and the wings are light reddish-brown.

S. greyi, a small reddish species found chiefly in the Coburg Peninsula.

S. pumilus is a small dark-coloured bat commonly seen hawking over rivers and waterholes. It is not uncommon around Sydney, and I was on one occasion shown some over the Narrabeen Lakes, their rapid movements near the surface being not unlike those of swallows.

Vesperugo abramus, a common Australian species, visits Europe in summer time.

Vespertilio macropus, found in South Arstralia, is distinguished by its long ears and large hind feet.

$V$. tasmanensis, equally common in Tasmania and the south-eastern portion of the mainland, has conspicuously red nose and lips.

1 The Mammals of Australia. 


\section{BATS}

i. Fruit-eating Bats (Flying Foxes or Kalongs)

The Common Kalong . . . Pteropus poliocephalus

(N.S.W.)

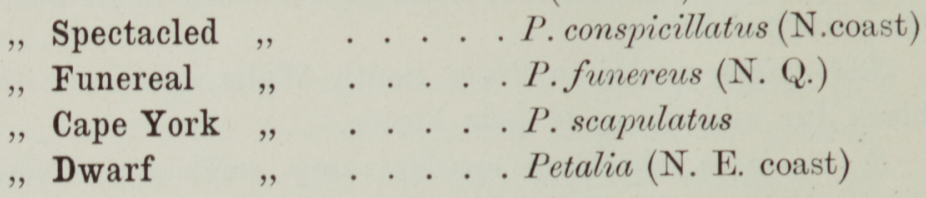

ii. Insect-eating Bats

The Great Megaderma . . . . Megaderma gigas (Q.)

Molossus australis (V.)

M. wilcoxii (E. coast)

Taphozous australis

(N. A.)

The Great-eared Horseshoe-Bat . Rhinolophus megaphyllus

,Fawn-coloured , , , . R. cervinus (Cape York)

"Orange ", . R. aurantius (Coburg P.)

Geoffroy's Long-eared Bat. . . . Nyctophilus geoffroyi

Gould's

The Tasmanian

"Timor
(W. A.)

. N. gouldi (W. A.)

. N. unicolor (T.)

N. timoriensis (W. A.)

N. australis (N. S. W.)

Gould's Short-eared Bat . . . . Scotophilus gouldi (S. A.)

The Chocolate ", . . . S. morio (N. S. W.)

„, Small-toothed " . . . S. microdon

"Pied " , . . . . S. picatus (S. A.)

S. nigrogriseus (Q.)

Grey's $\quad, \quad, \quad$. . . . S. greyi (Coburg P.)

The Little " $\quad$ " . . . . S. pumilus (N. S. W.)

Vesperugo abramus

"Great-footed Bat . . . Vespertilio macropus

(S. A.)

V. tasmanensis 


\section{CHAPTER IV \\ THE D U GON G}

Now and again, though yearly scarcer, as your ship is steaming at half-speed inside the Great Barrier Reef, there is a ripple in the clear, coral water and a grotesque creature, sometimes hugging an equally grotesque young one to her motherly bosom, emerges panting from the surface. This is the famous Dugong (Halicore australis), first cousin to the little American Manatee which recently attracted so much attention at the London Zoo, where, housed for want of suitable tank and temperature elsewhere in the Reptile House, it munched contentedly large lettuce leaves and tufts of the coarse African grass plucked from the baskets overhead. But for the Dugong having a forked, and the Manatee a convex, tail, the outward resemblance is great; and there is absolutely no beauty in the former to deserve the family name Sirenia bestowed on these unseductive creatures by Illiger, doubtless in allusion to the belief, dram inspired, of sailors that they had seen mermaids.

Among the other members of this large and important family, mention may be made of two, the Red Sea species, classed as II. tabernaculi with reference to a theory that it 
was with the skin of this animal that the Jews of Scripture covered their tabernacle; and the now extinct Rhytina, known as Steller's Sea Cow, which was exterminated by the greed of man within a comparatively short time of its discovery in the North Pacific.

But for the praiseworthy efforts of the Queensland Government to preserve it, the Dugong, which has much more to recommend it than its departed relative, might also have become extinct ere now. It is ever thus. In the mighty changes wrought in the animal world by the hand of man, the larger beasts and birds are the first to go. They offer greater attractions to the all-destroyer. And they are of milder disposition than their smaller prototypes. Anyone can appreciate this by comparing the mild sperm whale with the voracious little porpoise, or the huge basking shark with the spotted dog-fish. So we sweep them off the face of the earth, preserving only such relics in the national museums as shall make our children remember to curse our folly.

The Moa is gone ; the Mastodon is no more; and where, in fifty years' time, shall we seek the whale and dugong, the latter more especially, which cannot escape to colder seas?

Yet its uses are certainly sufficiently great to induce the Queensland Legislature not to relax its efforts for the preservation of the animal, which has been ruthlessly slain with spear and stake-net; by the aboriginals for food, by the colonists, who know it as the "Young 'Un," for the sake of its hide, the ivory-like heavy bones and tusks, and above all the fine, clear oil, which, especially that taken from the cows, has long been' known as a valuable specific, the discovery of which was announced many years ago by a Brisbane practitioner. And though chiefly eaten by the blacks, dugong "bacon" is rather liked by white 
men who can get nothing better. The food of this massive and inoffensive creature consists only of sea grasses, and a glance at the fragile flippers and great bulk will suffice to disprove the yarn once, if not still, current to the effect that this animal and the manatee leave the water on moonlight nights and commit great damage in any cornfields that lie handy.

I have watched these gregarious sea-cows browsing in the submarine pastures of Queensland estuaries, and can well understand how, in the shallow water, their massive bones assist them to remain at the bottom when feeding. The best case of stuffed dugongs I ever saw is in the Colombo Museum, the sexual differences, the enormous size of the female and the protruding tusks in the upper jaw of the bull, being at once apparent. 


\section{CHAPTER V}

\section{WHALES}

IT is quite beyond the scope of a small volume like the present to give any detailed account of the cetaceans of Australian seas, and a mere acknowledgment of their presence in the marine fauna must suffice.

Ignoring altogether the dolphins and porpoises, a few words may not be out of place on the subject of the whales.

These great creatures, which must have revelled in the water-logged earth of Middle Tertiary times, are getting scarce in Australian seas, as elsewhere, though indiscriminate slaughter seems, so far at all events as those latitudes are concerned, less to blame than voluntary migrations in search of food.

Over the very interesting natural history of the whale, I may not linger. The very name recalls a most spirited lecture by the late Rev. J. G. Wood, which I heard a good many years ago when at Clifton College, in which we were shown the error of confusing the great leviathan with fish, how the forked tail rests horizontally and not vertically as in the latter class, how the so-called fins are merely gloved hands, and how, above all, the monster breathes with 
lungs, so that, if detained below the surface after the exhaustion of the oxygen in its blood, the whale would drown like any other of its class.

It could not, indeed, dive for so long without the aid of a wonderful plexus of accumulated aërated blood, as also of certain valves which, when it dives or "sounds," close automatically and prevent its choking by the water entering the ears and blowhole.

I have watched several spermaceti-whales (Macrocephalus) spouting near the Tasmanian coast, and the glass revealed in each case only a single jet of white vaporous spray. Some whales, I gather from illustrations in Ballantyne's books, emit a double jet. The enormous head, from which this species derives its name, occupies nearly one-third of its length, and the wide gap of the great toothed jaws could easily accommodate a human being, thus contrasting with the Right, or Baleen, whale, which would choke in swallowing a herring.

The teeth of the sperm whale, which are situate for the most part in the lower jaw - though there are rudimentary teeth in the upper--are not used for masticating, as the flying squid, which at certain seasons constitutes its chief food, is swallowed whole. These teeth are familiar objects in the curio shops, where they are sold rudely engraved with pictures of the whale-hunt. Minute fry and other small organisms are also consumed by the gallon; and my ship recently passed through miles of "whale feed," doubtless the little pteropod molluse known as "Sea Butterfly," which stained the surface of the Indian Ocean between Thursday Island and Java, and filled the atmosphere with a highly unpleasant fish-like smell.

The sperm-whale has none of the valuable baleen, or "whale-bone," but as much as a ton of the valuable spermaceti has been taken from the "case" in the forehead. 
The Right Whale (Balcena), on the other hand, is hunted solely for the valuable "bone," which fetches over two thousand pounds a ton, or at least has touched that market price. It is toothless, though, according to Eschricht, the unborn young have rudimentary teeth which, as we shall also find later in the platypus, are reabsorbed. The baleen is not developed in the very young cubs.

Whales generally figure strongly in museums, and visitors to the Cromwell Road collection are familiar with the striking skeleton in the great hall, as well as with the exhibits in the cetacean gallery underground. The Sydney Museum, too, had some splendid skeletons, including one of a large Catodon, which was prepared and mounted under difficulties, as may be gathered from an amusing account given by Bennett, ${ }^{1}$ and from a much fuller description by Macleay issued, with excellent photographs of the limbs, by the trustees.

And the powerful skeleton indicates the secret of the agility of this apparently clumsy creature, which, when attacked by saw-fish, or perhaps irritated by crustacean parasites, I have seen throw itself three or four times out of the water, an effort that must require enormous power.

Of the whale-hunt and industry I do not propose to append any account. Kingston and others have made those at home familiar with all the most picturesque details and dangers of the former, from the first "There she spouts!"- "Where away?"-to the final lance thrust, trussing up of the carcass, and removal of the true skin or "blanket" of blubber.

The industry is on the wane, and not even the enthusiasm of M. Borschgrevink, whom I heard lecture in Sydney to crowded audiences, could do anything to revive

${ }^{1}$ Gatherings of a Naturalist, p. 159 . 
it. Yet, in the old days, there must have been some brave fortunes made out of sperm oil, for in the year 1823 alone seven thousand tons of that valuable product were shipped from Sydney to the port of London. In 1830, the whaling industry in those parts seems to have reached its zenith, for ten years later it had already declined considerably, and has never since shown any signs of mending. 


\section{CHAPTER VI}

\section{SEALS}

There are three seals in Australian seas, the commonest being the so-called Sea Bear, Fur Seal, or Eared Seal (Arctocephalus lobatus), the most scarce the Sea Leopard (Stenorhynchus leptonyx), an occasional straggler only from southern seas, and the third, the Sea Elephant (Morunga elephantina).

The Fur Seal is somewhat misnamed, since its fur is at best very inferior to that of the American animal, about which there has been so much wrangling of late, and in the majority of specimens there is none of the dense under-fur at all, only coarse hair. The chief uses of this creature with the comical ears would seem to be for exhibition purposes, where it delights the audience by walking on all fours, like a dog after its keeper, and the extraction of oil from its hide. This must have been the seal to which Collins ${ }^{1}$ referred about a hundred years ago, and which gave their name to the Seal Rocks, north of Sydney, on which the ill-starred Catterthun went to pieces last year. The cubs of this species are almost black until

${ }^{1}$ An Account of the English Colony in New South Wales, 1798. 
the brown under-fur, which disappears in the adults, develops.

The largest of Australian seals is the Antarctic Sea Leopard, so called from its black spots, which grows to a length of ten feet or more. It is easily distinguished by its size and skin from the preceding, as also by the absence of external ears and under-fur. Moreover, it can only drag itself along on its belly when out of water, the formation of the hind limbs preventing its walking on all fours like the bear.

The natural history of this family is too well known to detain us here; and those who desire some sensational facts about the fur seal of the North Pacific, should turn up the file of the London dailies during the prolonged silly season while the Behring-Sea trouble was at its height. It is only necessary to recall the main characters of all, the abnormally large brain, the cleft tongue, long, sharp teeth, ears and nostrils closing hermetically under water. They are extremely sociable, though the old bulls - each of which has several females-fight terribly when they first come ashore to breed, which is some time in August or September. The young are born before Christmas, and the females take to the sea again early in the new year. The seal, when unsophisticated, is one of the most gentle and trustful of animals; only, after it has learned the ways of man, it grows unsociable and absents itself when possible. 


\section{PART II.-THE MARSUPIALS}

\section{INTRODUCTORY}

As we shall have to consider the Marsupials at some length, taking the different families seriatim, it will perhaps be as well to give some facts that apply generally to this remarkable order.

Perhaps the keenest interest which it possesses for the student is its great antiquity. Creatures not unlike the kangaroo once leapt among the plains of our own island, and indeed the oldest mammal remains in our Secondary deposits are referred to this type.

As the progress of all things living is toward the higher type, so are these ancient mammals also, if we except the bird-like monotremes, ${ }^{1}$ the lowest. Nature's ways, if slow, are perfect. The extinction of these surviving marsupials can only be a matter of time, for besides being slow breeders, giving birth to but one or two at a time in the majority of the species, they are ruthlessly slaughtered by the settlers as they were by their black predecessors. Though of little value as food, and incapable of being domesticated to perform any useful work, they are 
killed on all sides, for the sake of their skins or for the mischief they do on the cattle runs. The skins, which are at their best in the winter months, are sufficiently handsome, when manufactured into rugs, to command a price. They are, however, worth considerably less than the skins of most other fur-animals, for very many reach the market at the wrong season, having been collected in the warmer months, and the animals being in many cases of small size, half a dozen skins go to the making of each rug, which, in consequence, assumes a patchy look. Moreover, the skins of the so-called 0possums are often sadly spoilt by shot as well as by rough handling, before they are cold, with the curious result that the fur comes away in tufts. The beautiful skins of the Flying Squirrels are, in the majority of cases, too fragile to work upon. But though the furriers always take a certain supply, by far the greater number of the larger members, the kangaroos and wallabies, meet their death at the stockkeeper's hands after he has resolved to put a term to those destructive raids in which they mow the grass to the very roots, leaving the cattle to die of starvation.

So that the marsupials must gradually retreat from the path of the white man. As it is, a single family of American opossums excepted, the Australian region (New Guinea and the islands belonging to the same zoological group included) is their last stronghold. ${ }^{1}$ Or, as one writer ${ }^{2}$ admirably expressed it in a work that appeared while I was out there, "Australia has served as a kind of ark, or city of refuge, for animals once abundant in Europe and America, as well as for plants which, a few score thousand years

${ }_{1}$ With reference to the disputed range of this order, Mr. Hudson mentions having encountered marsupials in Patagonia, where, according to many authorities, none exist.

${ }^{2}$ Barton: Australian Physiography. 
later, were equally luxuriant there, but all of which have long been extinct in their original habitat. . . . Our native zoology and botany are to a great extent 'restorations' of the fossil zoology and botany of the Old World."

Although considered in the present remarks as one order, it will not do to lose sight of the great variety presented by these animals in size, form, and habits. In size the differences are especially striking, for, not to mention the extinct diprotodon, thylacoleo, and nototherium, all of vast dimensions, we have still the great Red Kangaroo to contrast with the pigmy Antechinus.

What two animals, for example, could differ more in appearance than the ungainly Wombat and the graceful little Bettong, or, in habits, than the Tree-Kangaroo and Pouched Mole? Surely we shall find in the half-dozen chapters that follow beasts to correspond with almost every family of placental mammals, carnivora, insectivora, herbivora, and the rest.

The name marsupial cannot be called very happy as a collective term, for in one ant-eating species (the banded Myrmecobius) and in some of the pouched mice, the tribal badge is either replaced by a mere fold of bristles or else entirely wanting.

The pouch, found only in the females, is a remarkable external purse-like bag, lined with soft hair. Except in the bandicoots, it opens directly downwards, and in the larger animals is of considerable depth. It is associated with two epi-pubic, or marsupial, bones, the functions of which, though they doubtless help to support the pouch and its contents, and also perhaps, as suggested, to press on the milk-secreting glands, cannot yet have been satis. factorily determined. For Nature's workshop is regulated with due regard to economy; and were these their only uses, she would scarcely have bestowed them on the male 
of each species, as well as on the female platypus, which has no pouch. The proportionate size of these bones varies considerably; in the Koala they are largest, in the Myrmecobius they are smaller than in the rest. It must also be borne in mind that the pouch of the Thylacine is unsupported by bones of this description. ${ }^{1}$

Allusion was made in the introduction to the helpless, practically embryonic, state in which this order brings forth its young.

Among their favourite narratives, "eye-witnesses" used to relate in their letters home how the young were born in the pouch itself, springing bud-like from one of the four nipples.

This remarkable version even found credence among medical men, one of whom, a naval surgeon, ${ }^{2}$ writes: "From this singular mode of gestation, you may handle the foetus in utero, and pull it about by the tail, like a kitten, from the moment of its appearance there up to the very day of its birth, without causing either pain or annoyance to it or its mother."

At length the actual fact of the kangaroo's birth, which is much as that of other mammals, were carefully observed at the London Zoo, and the "budding" fiction joined the myths that were. It was there proved that the little "joey" is brought into the world in the usual way, and forthwith conveyed to the comfortable receptacle and affixed to a teat by the dam, which held the lifeless-looking little thing tenderly in her cloven lips. The teat is of sufficient length to pass down the throat and into the stomach, the milk being pumped into it by the action of

1 It was erroneously stated in one work that the male thylacine has a pouch, whereas in point of fact it has the same rudimentary marsupial bones as the female, but not the faintest trace of a pouch.

2 P. Cunningham: Two Years in New South Wales (1827). 
special muscles and prevented from choking it by a beautiful arrangement of valves that check the flow and prevent it from going down " the wrong way."

Born, then, in a practically embryonic state after a gestation (in the kangaroo) of only thirty-eight days, and without any blood-connection with the mother, the fragile atom of life is rapidly developed in the pouch to a stage at which it can shift for itself, a portion of its existence to which I shall allude in the next chapter. Gould is of opinion that the marsupials continue growing almost indefinitely.

The presence of a predominating marsupial order in Australia has, besides practically establishing the long isolation of that continent from the rest of the globe, also given rise to a number of ingenious theories professing to account for its survival in this last stronghold.

The absence of large indigenous carnivora is one, and this has been advanced, though scarcely with reason, against the early origin of the dingo. The late Professor Owen also had a theory that nature had designed the order to fight the battle of life amid the peculiar difficulties of those great central deserts of the only exclusively southern continent, where coastal ranges deprive the interior of all moisture from without. In the long droughts more especially, the Professor pictured the mother bearing her solitary offspring over vast tracts in search of water. And even apart from the pouch, it is at once apparent that, excepting the placental dingo and rodents, all the mammals of that land are wonderfully adapted to survive the sudden changes of temperature, droughts, floods and bush-fires, to which Australia is much given.

Their fur protects them equally from the hot winds and sharp frosts, which make both plains and higlands insufferable at times.

In the long droughts they can exist for some time with- 
out water, and can travel over long distances when hard pressed. Some burrow, others escape to the tree-tops, the kangaroos soon get away with their flying leaps, the bats, unless surprised in some cave, are always safe on the wing. For all that, the pouch of the marsupials and the scarcity of water in their native land are not quite so intimately connected, perhaps, as Owen thought. In the first place, Nature would have likewise equipped the animals of great waterless tracts in other parts of the world. Secondly, the only family of marsupials at present existing outside the Australian region, the true opossums, occur in some of the best-watered districts of America. And lastly, conclusive argument, the prevailing type in and around the great Australian desert is not, as might be expected, marsupial at all, but the rodents.

The presence of fossil marsupial remains in the earliest Australian strata, as well as in the secondary rocks of this country and France, warrants the inference that the present climate of Australia has prevailed for a considerable period and closely resembles that of pre-historic Europe. 'This is but another instance of the periodic " swing " of the Globe, and alternation of temperature in either hemisphere.

An interesting account of extinct marsupials is given in Mr. Lydekker's valuable monograph in Allen's Naturalist's Library. I shall not, therefore, discuss this portion of the subject, though the importance of some attention being devoted to the extinct fauna of a country cannot be easily over-estimated, since some light is generally thrown on the origin and development of existing families. 


\section{CHAPTER I}

\section{THE MACROPODS}

THe marsupial type with which we in the old country are most familiar is unquestionably the Kangaroo, and most visitors to the Zoo carry away some memory of the timid, awkward-looking creatures that limp lazily around their paddocks, and of the curious little Tree Kangaroo in the highly-perfumed building opposite.

The word Kangaroo, like Wallaby and Wallaroo, is of aboriginal derivation. One far-fetched explanation gave it as the native equivalent of "I don't know," the answer made by a black fellow to an early settler.

But it is ridiculous to imagine that the native, dense as are some of his kind save where it is a question of procuring food, could be so idiotic as not to know the name of a beast he had hunted all his life.

The chief features of the kangaroo type, the long hind-feet and feeble fore-limbs, the upright posture, erect ears, ratlike muzzle, and long flattened tail, are familiar to everyone.

Yet the mistakes made concerning its life-history exceed some of the wildest flights of travellers' romance. And the way in which these fables are gravely borrowed by succeeding writers is such as might be expected when we 
recollect that three-fourths of its biographers have only seen the kangaroo in captivity or in the museum.

The greater part of their romance centres round the tail. Many give such glowing descriptions of the high esteem in which kangaroo-tail soup is beld in the colonies, that one is

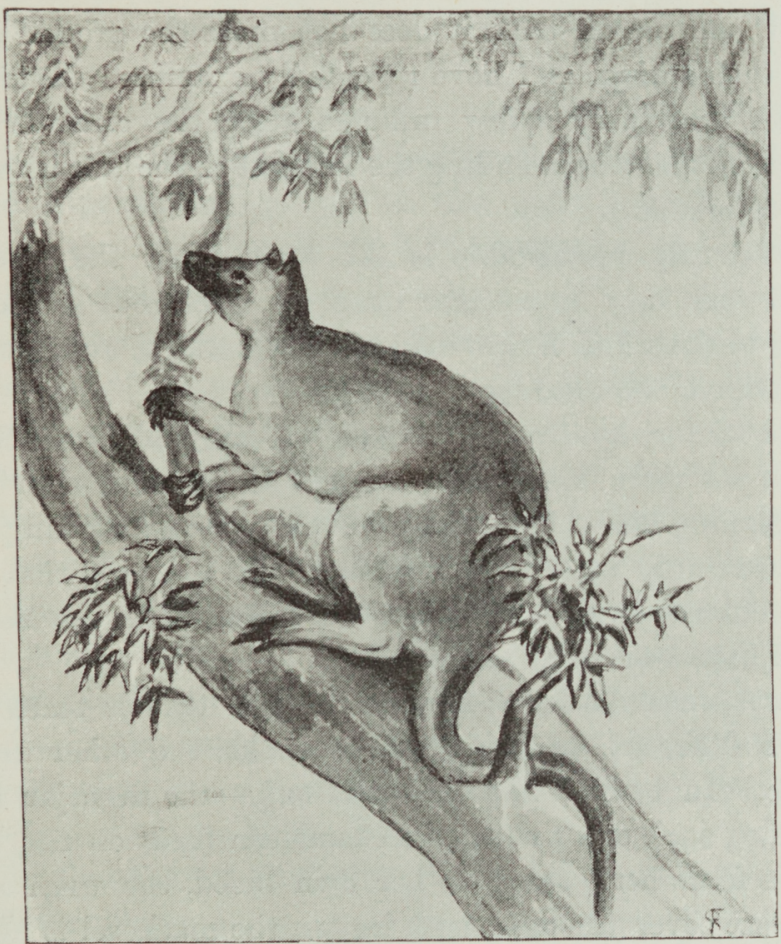

Tree Kangaroo.

somewhat surprised to find the orthodox "ox-tail " figuring in the club menu, while the vaunted native article is regarded as a pis aller, even in the "back blocks." The list of wonderful feats performed with the aid of this appendage might, if authentic, excite the envy of a monkey, whose tail is ladder and fishing-rod in one. 
We are told, for instance, that it is the resistance of the tail that contributes most to those grand twenty-feet leaps that can on occasion keep the hounds busy, or outstrip even the cruel bush-fire. That the massive tail affords great help in balancing the flying kangaroo and also in any abrupt change of course, few who have seen the chase will deny; but I am certain that it does not press the ground hard with each spring, as I have repeatedly examined the tracks in soft sand only a few minutes after the animals had passed, without once finding the imprint of the tail between the footprints.

Sufficiently remarkable is the attitude of the leaders, which one may sometimes observe, when out stalking, rising to their full height to scan the horizon, and resting on a tripod, the hind-feet and tail.

One writer, however, improves on this, and presents us with a yet more marvellous account of an "old man" at bay, leaning his whole weight on the tail, and striking out simultaneously with both hind-feet. It is a pity that the artist did not avail himself of the material, as the result would have been very pleasing.

Most animals behave, however, as our travels teach us, in two different ways, one as in books, the other as in nature. In books - and in books only - the rightjar and hedgehog suck cow's milk, the chameleon feeds on fire, the pelican feeds her young on her own blood, the wren and redbreast cover the dead with leaves, the mackerel is blind in winter-time, the bat and mole are always blind, and the swan sings immediately before its death.

In nature, on the other hand, many as are her wonders, the birds and beasts behave in a comparatively rational manner. The old kangaroo, for example, makes, when hard pressed, for the nearest rock or tree, with his back to which he faces the enemy, and unwary dogs have a rough time of it, and frequently receive their death-blow from the 
terrible hind claw. Bushmen sometimes make a successful detour by creeping round to the back of the tree, seizing the tail, and throwing the animal off its guard, when the hounds generally bring matters to a close. Or, with still greater cunning, the "boomer" will run all he knows for a neighbouring pond or "waterhole," where he stands up to the middle and drowns any dog that swims within reach.

The kangaroos have complex stomachs and somewhat curious dentition, comprising two lower incisor teeth (hence called Diprodonts) and six in the upper jaw, no canines (save in the upper jaw of the Rat Kangaroo), and in either jaw two premolars and eight molars.

Some threescore members of the family are enumerated at the end of the present chapter. I feel bound, however, to record a doubt as to the correctness of the list, for which I am indebted to Murray. ${ }^{1}$ The fur of certain species shows considerable colour-variation, and should have had less weight in the differentiation of species than the teeth or skeleton, which are far more constant and reliable.

It is also more than probable that naturalists, working independently in different colonies, described the same species in the early days under two or more names.

Some short description must now be given of the typical genera and species of the family.

The Great Grey Kangaroo (Macropus major), and Great Red Kangaroo (Macropus rufus), otherwise "Boomers" and "Foresters," are splendid animals, growing respectively to a height of five and four feet. The weight of the firstnamed species is not seldom between 150 and 200lbs., and the tail alone will scale over twenty pounds. Both these animals are typical of the group, and exhibit conspicuously its chief characters, the largely developed external ear, and

1 Geographical Distribution of Mammals. 
the long hind-feet with the large, pointed, central nail on the fourth toe. The fore-feet have five toes, the hind-feet only four. There seems, at first sight, something wrong about the long nail being on the fourth, and likewise on the inside toe; but the fact is, there is no first or great toe, so that the long nail is actually on the third, but practically on the fourth toe. In fact, the kangaroo's hind-foot has no big toe, but two little toes! I hope this is clear. ${ }^{1}$

In the kangaroo's mouth are twenty-eight teeth already classified, and little more than half the number owned by the small myrmecobius. The incisors of the lower jaw work like the blades of shears, cropping the short herbage to its very roots; and some writers are of opinion that these animals chew the cud, a proposition that has not received general assent. But the independent transverse action of the lower incisors can be witnessed any day where the beasts are kept in captivity.

Like the koala ${ }^{2}$ and a few of the so-called "pouched mice," the kangaroo family feed during the day, while the other marsupials are asleep. Hence the silence of the bush, for the nocturnal marsupials are just those which make most noise. An awkward figure the browsing kangaroos cut, limping on their weak forepaws and cropping the native grasses. But very different are they when, alarmed by some sign of danger, they cover the sandy ground in untiring leaps measuring between fifteen and twenty feet, and wonderfully regular. They remain almost erect when progressing in this way, and not, as sometimes represented, bent forward as if on all fours.

The first few weeks of the kangaroo's existence have already been alluded to. Only one is produced at a birth ;

1 Hypsiprymnodon (Queensland) has five toes on both fore- and hind-feet.

${ }^{2}$ Only the old male koala is generally found abroad by day. 
and the many writers who have called attention to the apparent incongruity between this single young one and the presence of four teats in the pouch have evidently overlooked the fact that the cub remains over six months in the latter and may subsequently make use of the others. Its early stages of development are well-known to the colonists. After two months, it will occasionally leave the automatic feeder, and thrust forth its rat-like head to crop the tops of the young grass. A little later, it leaps out to the soft earth and gambols in the shade, returning swiftly to the haven of refuge on the first sign of danger from without. By this time, the "running Joey," as the colonists call it, may weigh as much as seven or eight pounds, no mean burden for the solicitous mother, who carries it bravely in that burning heat, and will even fly with it before the fierce kangaroo dogs. I have more than once admired the dexterity with which she receives the young one when both are flying for their lives, and which is only equalled by the cunning with which, when too hard pressed, she can throw him out of the pouch sidelong into some soft bed of ferns, not-gross libel on motherly love ! - to create a diversion and throw the hounds off her own track, but in the futile hope of returning later to recover the fallen one, which lies just where it falls.

And the hounds, intent as a rule on the larger game, are rarely put off, so that the little one generally escapes scot free after all.

Passing for a moment from the physical development of the kangaroo to its mental standard, it would be interesting to know who first described the animal, nay, the marsupials generally, as lacking in intelligence. Some student, in all probability, too ready in his book-learnt comparative anatomy to draw conclusions from the shape of the skull or size of the brain. For the enumeration of 
purely physical characters, such as are given in his valuable catalogue by Oldfield Thomas, ${ }^{1}$ the dissection of specimens is all-sufficient.

When, on the other hand, we aim at giving some account, however meagre, of the habits of any wild animal in the state of nature, we must seek that animal either in its home or in the reliable narratives of those who have met it there. One of these courses is honest, the other general; but more natural history is studied and written in the cosy armchairs of public libraries than readers wot of.

Neither the bush, however, nor the genuine observations of those who have hunted or stalked the kangaroo, could leave much impression of that animal's stupidity, so the report must have had its origin in the dissecting-room. The kangaroo has, let us grant, but a small brain. The seal has, on the other hand, a very large one. Yet I have seen seals knocked on the head, one after another, as stupid as any booby on an unvisited coast.

Stupid! that splendidly alert creature stupid, with the sensitive, twitching muzzle catching the faintest scent, great eyes sweeping the clear horizon, hairy ears warning it of the slightest danger! I wish some of these biographers might creep after it as I have done by the hour in the full glare of that pitiless Queensland sun, and they would inwardly curse its intelligence instead of laughing at its stupidity.

Timid it is, as the hare or any other comparatively defenceless animal ; and in its agony of fear it will run pellmell before the shouting beaters right past the deadly barrels. Indeed, from the way the eyes lie back on either side the long, arched snout, the animal cannot see close objects directly before it, and has been known, with what has been miscalled stupidity, to charge right on an ambush and ${ }^{1}$ Catalogue of Marsupials in the British Museum. 
fall an easy prey to the butt of a gun. Few animals so large are as easily killed. The does have been known to die of fear, and few but the largest males can live before the hounds for half an hour.

With so little cover as the plains afford, stalking these suspicious beasts is, as already stated, very ticklish work. I have never crept through the damp Highland heather after stags; but visions of Black used to rise before me when wriggling along on the baked sand, and I often thought what a blessing a good Scotch mist would have been. One occasion I recall perfectly. It was in the coast plains of central Queensland. Hard by ran a swift and turbid stream carrying down to the reef-bound sea all manner of flotsam from a mining camp a mile or two higher up. Over this racing débris flew hawks and kites innumerable, while sharks and catfish did the necessary scavenging beneath the surface. With rifles slung we crept through the dense belt of oyster-studded mangroves and up the muddy bank, startling, maybe, more than one huge python and repulsive crocodile, of whose occurrence in Queensland this river is the southern boundary. As soon as we had emerged on the sandy plain, the glasses revealed a large herd of browsing kangaroo and wallaby, the whereabouts of which had been reported to us overnight. Cautiously as we advanced on the as yet unsuspecting beasts, every step flushed the long-billed ibis that flew shrieking from our path; and whenever we suddenly stooped out of sight, we were certain to light on a dozen hideous little landcrabs, which bade defiance with their grotesquely large claw.

The glasses being again brought into requisition after we had made a détour of about a mile, now revealed several of the creatures reared on end, sniffing the air and evidently suspecting mischief. It was disheartening indeed that such "stupid" creatures should observe us advancing 
in snake-fashion through the long grass, when, without the glasses, they looked to our eyes the veriest brown specks against the deep green background. Scarcely daring to breathe, we crouched to the earth forgetful of snakes, ants, and other solaces of bush life, until confidence was apparently restored. Another weary tramp of half a mile or so, and all further progress was blocked by a foul ditch, black and oozy. There was an abrupt halt, a muttered ejaculation, and a slight crackling of dry wood underfoot. Enough, though the objects of our care must have been full six or seven hundred yards off, and but for a miracle it would have been all up with our chance of a shot that time; the said miracle being that the "boomers" - veterans of the herd that are at times solitary and savage as the rogue elephant -having tapped on the ground as a signal to the females and young, led off most unexpectedly past our ambush. Doubtless, as we were on an island, much of which was unreclaimed swamp, escape was impossible in any other direction, and though no mean swimmer in river or sea, the kangaroo wisely refuses to trust its weight to the treacherous mud. So past went the whole herd in those leaps and bounds that make them such difficult butts for the "new chum." On this occasion, two fell victims, one to each gun.

Next to the kangaroes of the plains and those, nearly as large, which dwell among the rocks (and known as Wallaroos), where they roam day and night, come the smaller Wallabies, which also vary greatly in size. They have as a rule somewhat lighter coloured fur than the larger beasts, and most of them are further distinguished by their hairless muzzle.

Into the specific descriptions of the rock, swamp, brush, scrub and other wallabies I shall not enter. I have already referred the reader to Mr. Lyde'sker's admirable volume 
in Allen's Nairratist's Library which, as do also several more abstruse catalogues, gives such details. My intention has not been to reproduce other men's works, but rather to introduce them to the reader by a general sketch of the subject, in which my hope is to excite, and not to satisfy, some curiosity in Australian zoology.

In the matter of the distribution of these animals in that region, the reader will note with surprise that in so hilly and densely-wooded a country as Tasmania, the rockwallabies, as also the koala and flying-phalangers, should be wanting, a peculiarity for which the "tiger" and "devil" may be answerable.

Many kinds of kangarco and wallaby fly by at a drive, hurried on by the dogs or beaters. A heavy shot gun seems to be the correct weapon for this work; and those who take part are posted at intervals of two or three hundred yards, where they stand motionless awaiting the deep baying of the hounds and the approaching thumps of the flying game. Some little judgment is necessary in selecting the right moment for loosing the dogs; and I well remember the utter ruin of a most promising day on the banks of a lovely river by some one having liberated the hounds as soon as we landed, with the result that the frightened rock-wallaby were driven further and further away. Never better than at a wallaby shoot can you appreciate the death-like stillness of the bush and the weird, discordant voices of some of its birds, as you stand maybe half an hour with not another soul in sight. As already mentioned, the nocturnal habits of most bush animals are greatly accountable for this.

Yet a third phase of colonial sport is furnished by the three days' drive to which the squatter, weary of losing his starving cattle, invites his neighbours and acquaintances from all the country side. The kangaroos, no longer 
kept in check by the black man, must be reckoned with by the whites; and the method chosen is a periodical battue with much slaughter by day and feasting by night. The party, well and indifferently mounted, muster at dawn and beat up the surrounding cover for miles, hunting the terror-stricken creatures headlong down alleys that converge on a central yard, a veritable camera di morte, in which a scene presently ensues that scarcely invites description.

The dogs with which kangaroo are hunted in the open plains are powerful fighters and swift of foot, a cross between deerhound and greyhound. In the thick scrub, however, especially in parts of Tasmania, a smaller animal has to be employed capable of working in the undergrowth. It is a remarkable fact that when kangaroos are tamedand few wild animals answer more readily to kind treatment-they can roam with perfect safety among the dogs of the establishment. Their chief danger lies in wandering out of bounds and into the domain of dingoes or other strange dogs.

The same thing is, I believe, recorded of tame foxes in the old country.

In the Tree-Kangaroo (Dendrolagus), we come to a remarkable type, the only home of which was, until comparatively recently, thought to be in New Guinea, which has at least three species. In Queensland, there are but two, and these confined to the far north. Although this animal, distinguished from other kangaroos by the dentition, the long prehensile tail, and the feebler development of hind-feet, is truly arboreal in its habits, it is to be sought, not in the summit of the lofty bunya, as some artists would have us believe, but in the lower branches of less ambitious plants. And it may, en passant, be remarked that some rock-kangaroos (Petrogale), which have neither the massive tail of the largest kinds nor the 
slender tail of Dendrolagus, have a similar habit of leaping into small trees.

Like the cat, the tree-kangaroo has a knack of falling on its feet. It does not, like monkeys, swing from branch to branch with the aid of its tail, though that organ, often carried upright and not as by the other kangaroos, is doubtless of use in balancing it.

The Queensland blacks have an ingenious method of catching the tree-kangaroo or "boongarry," as they call it. They construct a fence of branches round the base of the tree in which it is observed asleep (for it sleeps the whole day long), and one of the party next runs up the almost straight trunk and climbs to a point above the unhappy beast, which is forthwith pelted with sticks and stones until it falls into the enclosure prepared for it, and is clubbed to death. But the natives stand in wholesome dread of its sharp claws. ${ }^{1}$ The hills behind Cooktown and also those in the Herbert River district are favourite hunting-grounds for this animal.

The very appropriate name of tree-kangaroo was suggested by the Swedish naturalist Lumholtz. There is one now in the London Zoo, lodged in the same house with the "opossums" and flying squirrels; and there was one there, for that matter, nearly fifty years ago.

The Nail-tailed (Onychogalea) and Hare (Lagorchestes), Wallabies are wanting in Tasmania, though three species of each are found on the mainland. The curious growth on the tail of the former reminds one of the similar horny

1 This recalls an ingenious plan, once told me by a South Sea eaptain, by which some of the islanders capture the large treeclimbing cocoanut crabs. This consists in tying a wisp of grass round the stem of the tree some distance above the earth; and when the descending crab comes in contact with this obstacle, it seems to think it has reached the earth, loosens its hold of the bark, and falling to the ground is stunned and easily secured. 
process on the tufted tail of the lion, and the old yarns of "eye-witnesses" who had seen the king of beasts taking a midday siesta, head downwards and hanging by this tailhook. The Hare Wallabies are graceful little creatures with black forelegs and hairy muzzle, which resemble their namesakes both in their preference for lying in a "form," and also in their fatal habit, shared to some extent by all the kangaroos, of doubling when pursued.

The Banded Wallaby (Lagostrophus fasciatus) of Western Australia is exceeding timid, escaping at the first suspicion of danger among the intricate galleries which it cuts in the dense mimosa undergrowth.

And lastly, the little Rat Kangaroos (Iypsiprymnus) "Potoroos" and "Bettongs," which average a foot in length, and are almost without exception characterised by rounded ears, white bellies and scaly tails. On opening their mouth, too, we find canine teeth in the upper jaw, alone sufficient to mark them off from the rest of the family. Although they nest as a rule above ground, their destructive burrows under the potato-beds frequently get them into trouble with the gardener. They do not leap, when pursued, like their namesakes, but run swiftly on all fours.

The Bettongs put their prehensile tails to the singular use of carrying small trusses of dry grass to the scene of nest-building. To take a typical example, Bettongia greyi burrows during the day. It produces but one young at a birth, but will breed two or three times in the year.

Macropodide.

Kangaroos, \&c.

Macropus major (N. S. W. and S. A.)

M. agilis

M. ocydromus (W. A.)

M. brachyotis. 
M. inornatus

M. concinues

M. eugenii

M. m.lanops

1I. unguifer

1. fuliginosus

M. antilopinus (Coburg Peninsula)

Osphranter rufus

O. isabellinus

O. robustus

O. parryi

\section{Vallaroos (Rock-Kangaroos)}

Petrozale penicillata (N. S. W.)

I'. lateralis (N. coast)

I. xunthopus (S. A.)

P. brachyotis (W. A.)

P. concinna (W. A.)

P. inornata (N. S. W.)

Wallabies, \&c.

IIalmaturus bennettii

II. ruficollis (T.)

H. manicatus (W. A.)

H. greyi (S. A.)

II. ualabatus (N. S. W.)

H. agilis (Q.)

H. dorsalis (N. S. W.)

II. parma (N. S. W.)

II. derbianus (S. A.)

H. houttmani

II. dama (W. A.)

II. gracilis

II. thetidis (N. S. W.) 
II. stigmaticus (N. Q.)

II. billardieri (N. coast)

II. brachyurus (W. A.)

\section{Banded Wallaby}

Lagostrophus fasciatus

Nail-tailed Wallabies

Onychogale unguifer (N. Q.)

O. frenata (V. and N. S. W.)

O. lunata (S. A.)

\section{Hare Wallabies}

Lagorchestes leporqides (V. and N. S. W.)

L. hirsutus (W. A.)

L. conspicillatus (W. A.)

\section{Tree-Kangaroo}

Dendrolagus humholtzii

D. bennettianus

\section{Rat-, or Jerboa-Kangaroos}

Bettongia penicillata (N. S. W.)

B. lesueuri

B. cuniculus (T.)

B. greyi (W.A.)

B. rufescens

B. campestris

B. gaimardi

Potorous platyops

P. gilberti

P. tridactylus

Hypsiprymus murinus

H. apicalis 


$$
\begin{aligned}
& \text { H. gilberti } \\
& \text { H. platjops } \\
& \text { Caloprymnus campestris } \\
& \text { Aepyprymnus rufescens, and } \\
& \text { Hypsiprymnodon moschatus (N. Q.) }
\end{aligned}
$$

With which we leave the macropods. I had on my return a baby rock-wallaby, since gone to the Cromwell Road Museum, which I took from the dead mother's pouch, in which, though the animal measured only three inches, the long pointed nail on the hind toe was already conspicuous. It is doubtful whether the last animal in the above list, with its five toes on both fore- and hind-feet, should, strictly speaking, come under the same category. 


\section{CHAPTER II \\ THE PHALANGIST $Æ$}

WE now come to a family of marsupials, including the so-called "Opossums," "Native Bear" or Koala, "Flying Squirrels" and a few smaller animals, differing in a marked degree from the foregoing in size, appearance, and habits.

They are all arboreal and all, excepting the old male koalas, strictly nocturnal in habits. The most important of this group are the "0possums," so-called.

'Possum shooting of a moonlight night is a favourite pastime out in the cold, silent bush. Gun in hand, you wander along the dim track, and, if unassisted by a dog, closely scrutinise the branches overhead, getting in line with the moon every suspicious fork that might harbour the motionless little animal. When at length you descry the upright ears, gun is brought swiftly to shoulder and the silence of that southern darkness is desecrated, as the report echoes along the gulleys. So perfectly still do these creatures remain in presence of the enemy, as to be often mistaken for part of the tree to which they are clinging. If the shot is a lucky one, down comes the furry body crashing through the leafy branches and falling with 
a thud on a rock hard by. More often, however, the sharp, curved nails, or bushy, prehensile tail will catch in the tree, and there swings the unhappy creature dead but useless.

This is a favourite position even in life with some of the phalangists; and folks in the bush tell of one that hangs

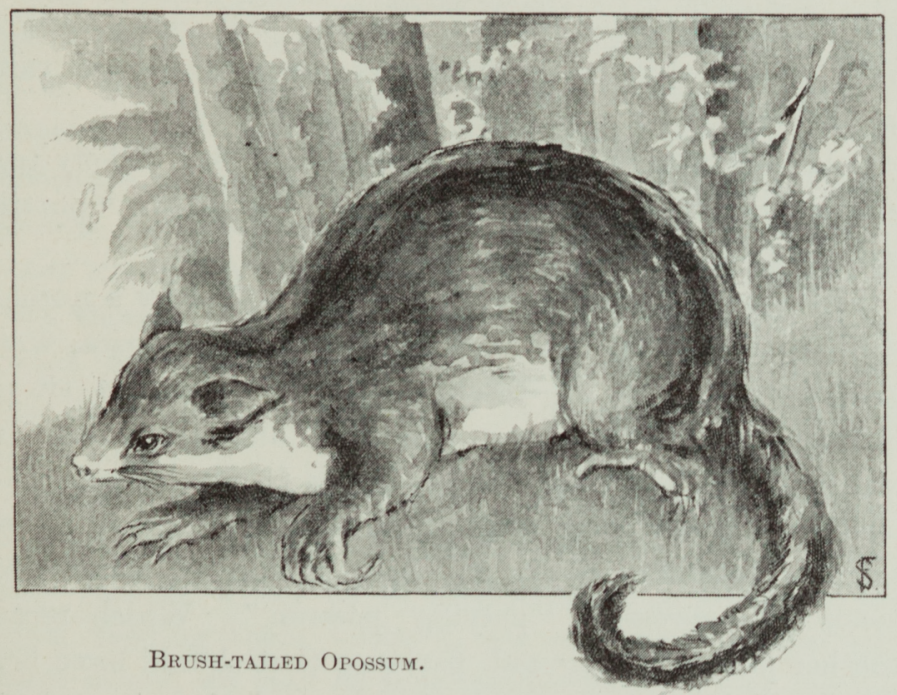

thus when closely watched, until, rather than betray itself, it falls weary to the ground.

The aboriginal is another sworn foe of the 'possum, hunting it for its flesh as recklessly as the white man persecutes it for its skin. Both he and his "gin" have wonderful instinct in detecting the presence of a prize in some hollow tree, a slight scratch or a wisp of fur on the bark being sufficient to catch their eye.

With but little effort they will ascend the bare, perpendicular trunk, tapping here and there with the waddy to ascertain by the sound the exact whereabouts of the coveted 
tenant, which is at length dragged forth from its hiding place and flung to the ground ere it can use its pointed teeth or powerful claws.

The sable gentry kindle forthwith a wood fire, on which the palpitating body is thrown, skin and all, and when halfcooked, they eat it. The skin hunter, on the other hard, is, or should be, careful to let the body grow cold, knowing well that, if handled sooner, the fur will come away in tufts and the skin be rendered in consequence of no value for the market.

Other enemies this pretty little animal has, chiefly treesnakes and dogs of every description, the latter "putting up" every opossum within reach.

This pseudo-opossum may be distinguished by a number of characters from the true Didelphys of America, while from the kangaroos it differs in its dentition, its simple stomach, its tree-frequenting habits, and, above all, the remarkable joint in the lind-foot, the family badge. It is somewhat remarkable that these animals have the same habit of feigning death as their American namesakes, hence the expression "playing 'possum." Which recalls another phrase in colonial parlance that should have been mentioned in the preceding chapter, and that is "on the wallaby," used of men tramping the country in search of work.

All day long these phalangers lie low in hollow trees, if undisturbed by any of their many foes, and at night they come abroad to refresh themselves on gum leaves and fruits -no longer invariably native fruits since the white man has given them a taste for something better. Their modes of progression vary greatly, as for instance the awkward groping of the Koala, the swinging movements of the 'possums, and the parachute descents of the flying squirrels. The "Opossums" are nine in number, the Black 
(Phalangista vulpina), Brush-tailed ( $P$. vulpecula), Ringtailed (Pseudochirus peregrinus), and Short-eared (Trichosurus caninus).

The Black Opossum is found only in Tasmania, and its beautiful glossy black fur and bushy tail are in greater demand than those of any other species.

The Brush-tailed and Ring-tailed have grey fur. The tail of the latter has a white tip, but there are no rings on it, as their name would lead one to infer. They are amusing and affectionate little pets, though a trifle uncertain in temper. When busy with a passion-fruit or banana, you may stroke the beautiful soft fur freely; at other times, however, there are claws to reckon with. The bite, though unpleasantly sharp, soon heals. The cage in which nocturnal creatures are kept should have a dark box in which they can, when so inclined, hide from the sun's glare.

Some folks have a mania for keeping all manner of pets without the patience to study their requirements. The only remedy would be to keep them for a week in a dark tank, feeding them twice a day on grass or ants' eggs. They would, we may be sure, study their protégés far more carefully after a little experience of this sort.

There are half-a-dozen species of Ring-tailed Opossum, of which mention may be made of Pseudochirus peregrinus, $P$. archeri, or the "tula," caught frequently abroad in the daytime, $P$. herbertensis and $P$. lemuroides of Queensland, P. cooki of Tasmania, P. occidentalis of Western Australia, and others in New Guinea. Into the Papuan fauna, however, I cannot, as already explained, enter at length.

I come to the Native Bear, or Koala (Phascolarctus), a familiar figure with its bushy ears, thick fur, bear-like awkwardness and sharp claws. The face is about as absolutely expressionless as that of any animal I know; 
but this cannot be properly appreciated in Museum specimens, as the taxidermist frequently imparts an intelligence that does not really exist. The "zig-zag" gentleman who exercises his talent for caricaturing at Regent's Park would make great things of this animal. Unfortunately, there has not been one at the Zoo for ten

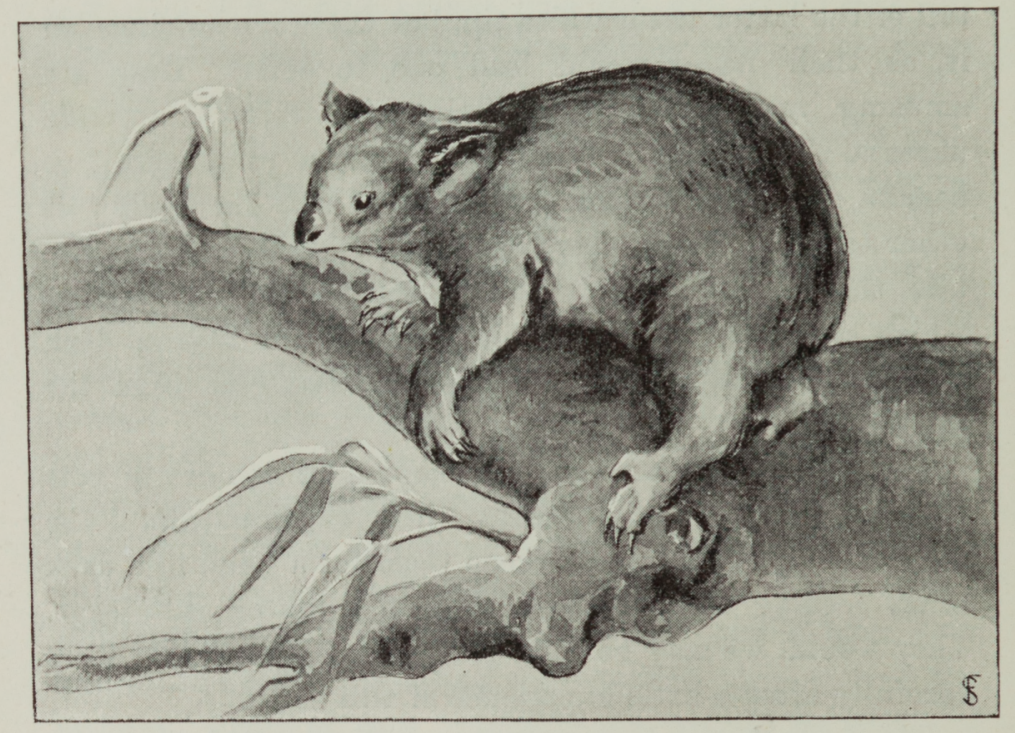

KOALA.

or fifteen years, and that specimen lived in captivity but a very short time. By reason of its fondness for gum-leaves, it is most difficult to keep anywhere out of Australia. It is a case of gum-leaves or nothing. Even with this food in abundance, it seems to die easily in the cage. I recollect several cases in Sydney. If the leaves give out it is hopeless; and I remember on one occasion, on a homewardbound P. and O., a couple dying off Naples within a few 
hours-whether due to sudden fall in temperature or to the leaves giving out, I forget.

Australian farmers, who, unlike those in this country, cling obstinately to all manner of erroneous impressions, charge the poor Koala with doing endless mischief in their orchards.

So far, however, as the fruit goes, the flying-fox and fruit-pigeons are the responsible parties. The former, as already mentioned, is especially so; for so powerful is its fotid odour, that peaches simply brushed by its wings, as it flits aimlessly among the trees, are absolutely unfit for the market.

In spite of the fact that its hind-feet more especially are admirably adapted for climbing, and partly because it lacks the aid of a tail, the Koala is but a poor climber, so far at least as rapidity goes, creeping painfully among the branches. So deliberately indeed does it move, that "bear-shooting" cannot be said to rank high among colonial sports. The female, often bearing her solitary young one on her back, rarely comes forth save at night; but the old males will shuffle out by day, and are occasionally shot by parties out stalking kangaroos. The piteous cry of a wounded Koala is enough to make one forswear shooting for ever. Like the "opossums," it frequently baulks the sportsman, the long nails catching in the branch on which it is walking, so that on being hit it swings round to the lower surface, to which, even in death, it clings like a sloth.

The distribution of the Koala is somewhat limited. New South Wales and Victoria are its headquarters, and it is most in evidence in the months of March and April. It is also found in Southern Queensland, and in South Australia, if it occurs at all, it is very rare; and in Tasmania, I believe, it is wanting altogether. 
Perhaps the nearest approach, anywhere out of Australia, to the Koala is to be found in the arboreal sun-bears of the Malay Archipelago. The absence of tail and general appearance distinguish it in so marked a degree from the other phalangists, that some naturalists have proposed to separate it altogether, in spite of the similarity in hind-feet and dentition. But this, I think, cannot be accepted.

The Queensland Striped Phalanger (Dactylopsila trivirgata) lives entirely in trees, and although, like the rest of the family, it is fond of gum-leaves, the sharp claws indicate an aptitude for digging grubs out of the soft bark.

In accordance with the prevailing colonial fashion, the Flying Squirrels (Petauri) are egregiously misnamed; for their parachute descent is in no sense flight, nor are they squirrels. They fly neither like birds nor bats nor flyingfish. In a few books, it is true, they fly from the ground to the tree-tops; but the chief aim of travellers' artists is to amuse, and in this they certainly succeed.

In nature, these creatures can only descend in the air. When they wish to ascend a tree, they run up the trunk, the opposable thumb on the hind-feet giving them a good grip of the branches. On the ground, their movements are almost as grotesque as those of bats.

When the animal is thus at rest, the parachute, which is generally dark above and white or yellow on the under-side, folds away in inconspicuous folds.

Bennett ${ }^{1}$ notices a curious habit they have, these petaurists, of spreading the parachute when lifted by the tail, apparently an instinctive movement to save themselves from falling. Any one who is curious to see this put to the proof had better, if convenient, make friends with the keeper of these graceful little animals at the Zoological Gardens. 


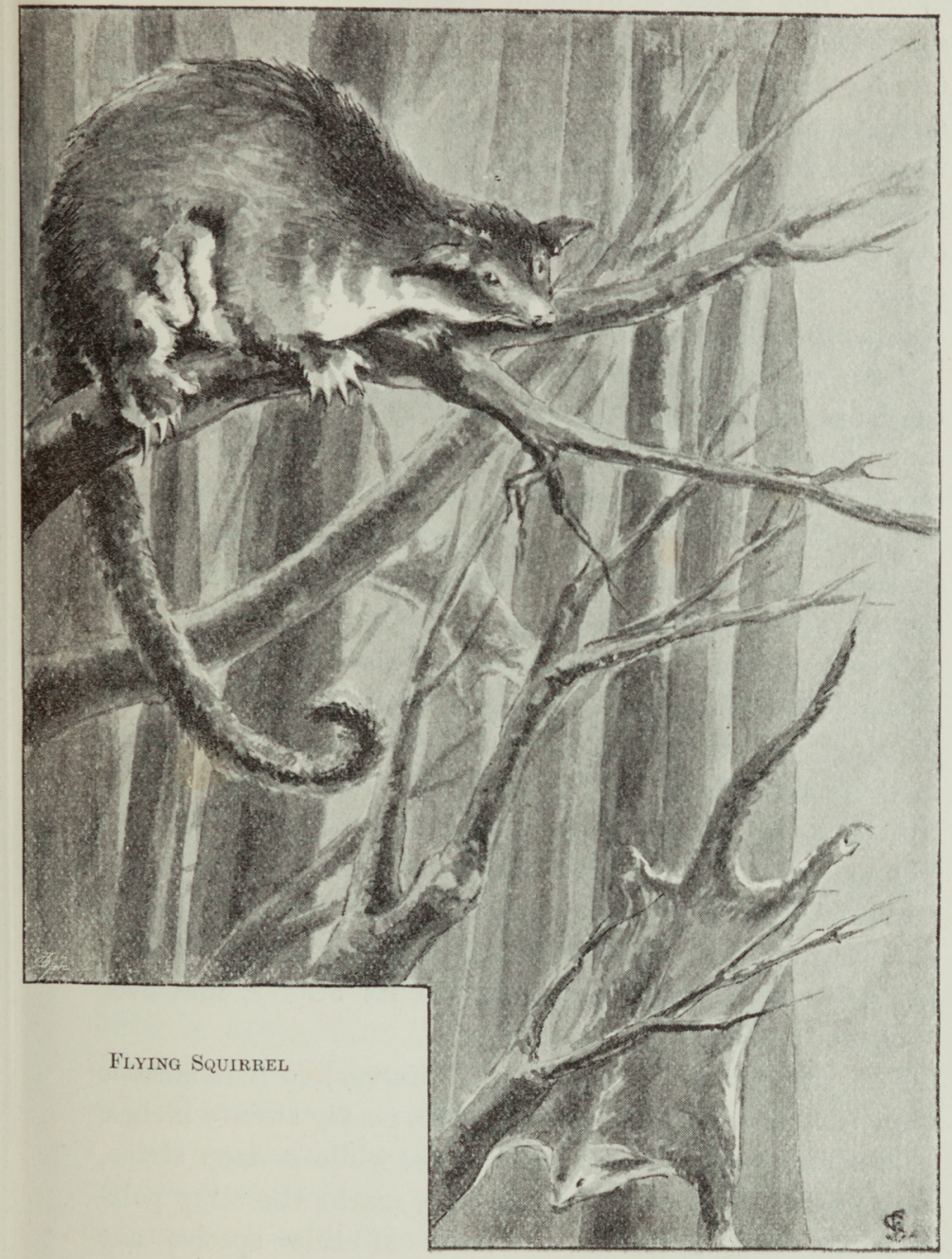


Like the majority of phalangists, they are of nocturnal habits, and those desirous of seeing them to advantage amid their weird natural surroundings are advised to loiter any moonlight night in the shadow of some tree. Quite early in the morning, just at dawn, I have seen a few, but they are very scarce at that hour; and ere the lyre bird's first warble and the cackling of the jackass fall upon the ear, the last flying-squirrel is asleep in its favourite hollow spout.

I enumerate a few of the chief species:

Petaurus taguanoïdes, the largest of all, measures, with the large and bushy tail, quite three feet. It is brownish or dark-grey above, and white below. Its food consists chiefly of leaves, and its flesh is said to taste excellent. Personally, however, I tried no experiments with these bush animals, as they had a pungent odour of their own that seemed to invite no nearer acquaintance.

Quite one of the handsomest of these petauri is the "Hepoona" (P.austratis), which has a brown parachute strikingly edged with yellow, and a long, bushy tail, the latter being either curled round some bough, or held over the back, as in the favourite attitude of the squirrel. The long, hairy ears are naked at the tip.

The "Ariel" ( $P$. breviceps) is somewhat similar in colouring to $P$. taguanö̈des, though a much smaller animal. It is vicious in disposition, for all its beauty, and ever ready to bite when handled.

The "Squirrel Petaurus" ( $P$. sciureus) is a handsome species, measuring, with the long tail, nearly twenty inches.

The under-surface is purest white, while a deep stripe, following the direction of the spine, marks the silky palegrey fur of the back. The ears of this species are remarkably small.

The little Gymnobetideus leadbeteri, which is only about 
half the size of the preceding, is practically confined to the colony of Victoria.

We now come to a genus of so-called "flying-mice," which have no parachute whatever.

These are the Dromicice. Their distribution is also of the most limited. One, for instance, is found only in New Guinea, another (Dromicia concinna) is restricted to West Australia; while two more (D. nana and D. lepida) are peculiar to Tasmania. They are all partial to honeyblossom, swinging from branch to branch of the flowering trees by the aid of the prehensile tail.

The largest of all, D. nana, measures, tail and all, but ten inches.

The three remaining members of this family are widely different in habits and appearance.

The 0possum Mouse (Acrobates pygmaus), a very graceful little creature, is confined to the southern colonies. It is dark-grey above and white below, lower surface of the parachute very light, muzzle naked and the tail covered almost to the tip with yellow hair.

The Long-snouted Phalanger (Tarsipes rostratus) is confined to Western Australia, to the aboriginals of which district it is known as the "Mulbenger." The great peculiarity about this animal is the serrated tongue, with which it extracts honey from the flowers.

And lastly, the Spotted Cuscus (Phalanger maculatus) which, in spite of its vegetable diet, is known in some localities as the Tiger Cat, occurs only in the extreme north of Queensland ; the rest of the family have their home in New Guinea and adjacent islands. In the male only, the greyish-white fur is marked with brown blotches, and the tail is half-naked, half-furred. Although the latter is prehensile, the Cuscus is little better as a climber than the tailless Koala. 


\section{Phalangiste}

Opossums ..... $\left\{\begin{array}{l}\text { Phalangista vulpina } \\ \text { Trichosurus caninus (E. coast) } \\ \text { Pseudochirus peregrinus (E.coast) } \\ \text { P. occidentalis (W. A.) } \\ \text { P. lemuroides (Q.) } \\ \text { P. herbertensis (Q.) } \\ \text { P. cooki (T.) } \\ \text { P. archeri (Q.) }\end{array}\right.$

Native Bear . . . . . Phascolarctus cinereus (E. coast)

Striped Phalanger . . Dactylopsila trivirgata

"Flying-Squirrels" . $\left\{\begin{array}{l}\text { Petaurus taguanö̈des (E. coast) } \\ \text { P. australis or flaviventer (S.E. c.) } \\ \text { P. breviceps (E. coast) } \\ \text { P. sciureus (E. coast) } \\ \text { Gymobelideus leadbeteri (V.) } \\ \text { Dromicia concinna (W. A.) } \\ \text { D. nana (T.) } \\ \text { D. lepida (T.) }\end{array}\right.$

Opossum Mouse . . . Acrobates pygmaus

Long-snouted Phalanger. Tarsipes rostratus (W. A.) Spotted Cuscus . . . Cuscus maculctus (N. Q.) 


\section{CHAPTER III}

\section{THE WOMBATS}

These remarkable burrowers (Phascolomys) have been termed the badgers among marsupials, and they certainly bear some general resemblance to that persecuted animal. Their habits are much the same, both burrowing and chiefly by night; their food is also similar, consisting for the most part of roots. In the natural state, that is; for in captivity animals develop all manner of remarkable tastes. In disposition, the Australian animal, though capable of biting severely when at bay, is the gentler of the two. The damage it can do among the roots is considerable, for it has the assistance of short, powerful legs armed with eighteen curved claws, and four-andtwenty sharp teeth. These teeth have no roots.

The shortness of the legs and small size of the feet will at once strike any one who compares them with the bulk of the creature, which grows to a weight of 60 or 70 lbs. There were older wombats, now extinct, to which those at present existing are mere dwarfs.

The animal is getting scarce, though it was recently abundant at special places, notably Wombat Brush near Goulburn, and "Stony Rises" in Victoria. 
'The wombat's eyes are small and far apart, the nostrils abnormally large, and the upper lip deeply cleft. Many people would at first glance pronounce it to be a tailless animal; but the tail, though so small as to be hidden beneath the coarse hair, is nevertheless present. For all its bulk, it can run bravely enough; indeed, it regains

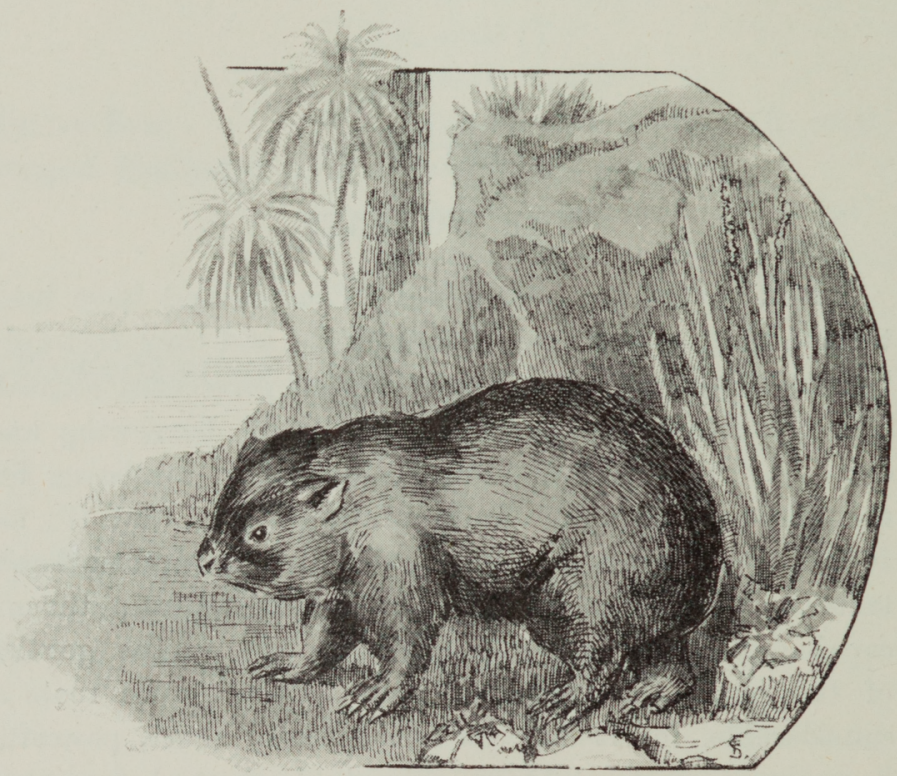

Wombat,

its burrow, even when wounded, so swiftly, that it is best shot when at some little distance from it, and with its head turned away; otherwise, back it scrambles to die underground. They are extremely sociable, many families inhabiting the same dwelling-even, it is said, in succeeding generations. What becomes of the bones, however, especially as the animal has fifteen sets of ribs, I do not 
know. Though swift of foot, as above mentioned, the wombat can neither leap nor climb, as may be seen from a glance at its skeleton. It reproduces its young but slowly, most probably one cub only at a birth, though some writers mention three or four. Silent the creature is, as most of the marsupials, the only sound ever heard from it being a peculiar hissing when irritated.

With regard to the actual number of species now in existence there seems to be some little difference of opinion; but naturalists are generally agreed on three as the correct number, namely, the widely distributed Broad-headed Wombat (Phascolomys latifrons) the hairy species (P. setosus) of Adelaide, and the Tasmanian kind, not found on the mainland ( $P$. ursinus).

The other so-called species seem to be merely local colour varieties.

The fur of the wombat is of little or no value, though the specimen skins, of which there is an excellent example in one of the courts at the Imperial Institute, make up well. The flesh is very rich and fat, and after tasting it once, I did not yearn for a repetition. But my experiences of bush food are so slight as to be worth nothing; and I believe that, as a matter of fact, the flesh of this animal is, when properly cooked, in some esteem among colonials.

In captivity these animals are fairly satisfactory. Those who have visited the wombats' cages at the London Zoo are probably familiar with gentle old "Tom," who is quite attached to the keeper, as well as with the more recently imported old male, who attacks every one within reach, keepers and all, uttering the peculiar hissing before alluded to. Years, many years, ago there was at the Hamburg Zoo one of the finest in Europe, a venerable male wombat living on terms of great friendship with a small agouti. 
But they have long since joined the great majority of wombats and agoutis!

\section{Wombats}

Broad-headed Wombat . . Phascolomys latifrons

Hairy

Tasmanian

$$
\begin{array}{ll}
, \quad & . \\
, & .
\end{array}
$$




\section{CHAPTER IV}

\section{THE BANDICOOTS}

These graceful little creatures (Perameles) have, as previously mentioned, nothing whatever in common with the powerful Indian rat (Mus giganteus), to which the name properly belongs.

They burrow in the earth and feed on insects, the Rabbit Rat $^{1}$ (Peragale lagotis) being above all partial to certain larvæ found on the acacias. This is the species that burrows freely in the aboriginal burial mounds, but not, as alleged, for the purpose of feeding upon the dead. At certain seasons they also consume quantities of roots.

The tail, though long, is not prehensile; the ears, which vary in different species, are mostly long; and the pouch opens in the opposite direction to that of other marsupials.

Boo is perhaps the most common of the many aboriginal names for this family.

Besides the eight or nine species found in Australia, there are others in New Guinea and the outlying islands.

They are all rather emaciated looking, which may perhaps account for the saying, "poor as a 'coot."

Belonging to the same family is the Chcropus castanotis,

${ }^{1}$ A name which is also applied to the placental Hapalotis albipes. 
which was provisionally recorded as $C$. ecaudatus from a mutilated specimen taken by Major Mitchell in 1836, and figured in his interesting journal. ${ }^{1}$

This erroneous specific name, originally suggested by Ogilby and retained even in Spencer Cobbold's Mammalia (in the Museum of Natural History, 186), was altered as soon as later specimens showed well-developed tails.

The female, in whose pouch are as many as eight teats, usually produces two young at a birth.

\section{Bandicoots}

Peragale lagotis (N. S. W. and S. A.)

P. lemura

Perameles bougainvillii

P. gunni

P. nasuta

P. macrura

$P$. aurata

$P$. obesula

Chceropus castanotis

1 Three Expeditions into the Interior of Eastern Australia (Vol. ii. p. 131). 


\section{CHAPTER V}

\section{THE DASYURES}

The larger members of the family under consideration are, excepting the dingo, the only carnivorous animals in the region under notice.

Their smaller kindred are, in spite of the bad name given them (especially $P$. penicillata) by some writers, in all probability insectivorous. Though it is not for want of teeth that they refrain, as few of them have less than forty, while Myrmecobius has the enormous number of fifty-four.

The stomach is simple.

They vary greatly in size, and have for the most part a hairy tail, long but not prehensile.

The presence of the "Wolf" and "Devil " in Tasmania has, as above suggested, resulted in the absence from that island of such helpless families as the rock wallabies, koala and flying phalangers.

With regard to the ears, it is worthy of remark that, except in some books and museums, these are invariably kept folded and never erect. A watchful thylacine, pricking its ears, is to be found in a certain popular book, but nowhere else. 
The Thylacine, called variously "Wolf," "Hyæna," "Tiger," and "Zebra," the last names in reference to the transverse black bars, sixteen in number, on its crupper, is a large and handsome beast now confined to Tasmania.

The short, black-tipped tail is so remarkably compressed, as to have led many to infer-especially as it is a confirmed beach-comber, prowling along the deserted foreshores in

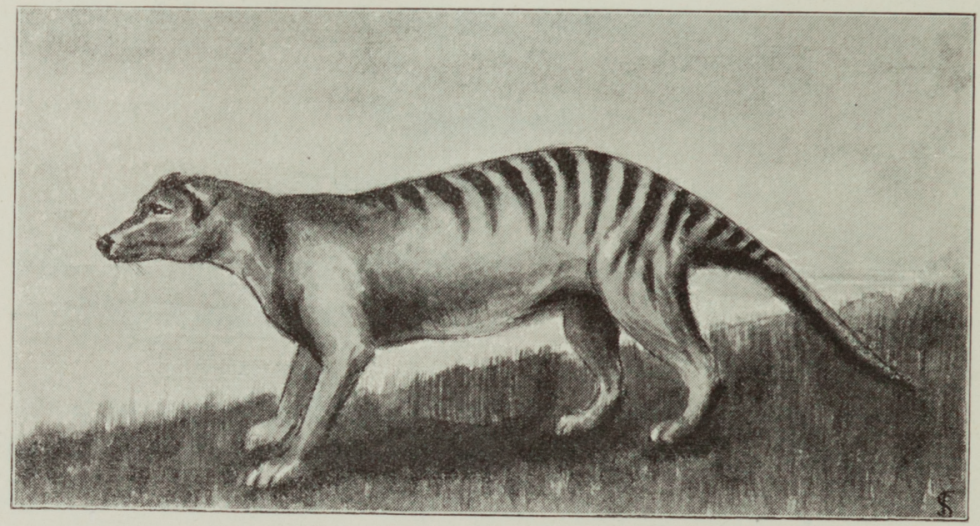

Thylacine.

search of jetsam - that it can swim with the aid of that organ.

The domestic cow may, as often stated, have a weakness for salmon; but the thylacine does most certainly not swim abroad after trumpeter and barracouta. The sharks would have something to say in the matter.

As foxes, moreover, have a well-known taste for ambergris, congregating on the seashore in search of that substance, it seems highly probable that the thylacine has some similar attraction on the beach.

This largest of the carnivorous marsupials measures when full grown, with the tail, about four or five feet, and has a very long muzzle. In the pouch are four teats, and 
this is the number of young in each litter. The pouch bones are, as already stated, absent, but on the other hand we find in both male and female two little flattened cartilages.

The Thylacine is a great despoiler of the sheep fold and poultry yard, but hunts in solitude, and not, like wolves, in packs. A pair of these animals were presented to the London Zoo as far back as 1849, but they are long: since dead and have never been replaced.

Visitors used to notice that, like the wombat, the male always uttered a hissing sound whenever the cage was approached, and at times it would fling itself violently against the bars.

Of purely nocturnal habits, like the next species, the Thylacine is ill at ease in the glare of daylight, and blinks piteously like a belated owl when mobbed by finches.

Bats, it may be remarked, which feed in the twilight, are nowise disconcerted by sunlight, and are frequently seen flitting about by day.

The Sarcophilus is well called the Tasmanian "Devil," for it has about as much of the latter element to the square inch of its misshapen body as any other living creature. It is one of those very few brutes on which, being absolutely untamable, kindness is lost. This unconquerable savagery is perhaps the more remarkable by contrast with the gentle disposition of most other marsupials, notably the wallabies and opossums, than which few wild animals are more easily domesticated, though not to any useful purpose. ${ }^{1}$

It is a forbidding animal, this "devil," entirely black, but for a white band or two and the pink nose and

${ }^{1}$ In his Wild Animals Photographed and Described, Mr. Nott quotes from the Times (1866) an instance of a kangaroo trained to work a chaff-cutting machine. 
ears. With the short, furry tail, it measures a couple of feet, and is particularly repulsive by reason of the thickset muzzle and formidable teeth. Though only about half the size of the thylacine, it is yet more dreaded by dogs, which rarely face it alone. Its habits are similar to those of the preceding, even to the prowling on the lonely shore of a moonlight night. It is also a famous burrower. Five is the usual number of young produced at a birth. There is one at the London Zoo, which made so much noise of a night that it had to be relegated to a solitary box of its own outside the Lion House, where, strangely enough, it has become quite accustomed to the sun's rays.

Like the thylacine, the "devil" formerly existed on the mainland.

The Dasyures proper, or "hairy tails," comprise the so-called Native or Tiger Cats, not to be confounded, however, with the more harmless Cuscus, to which the epithet has also been applied. These "cats" are of slender build, armed with sharp claws and pointed teeth; and they play in Australia the same part in nature's economy as our weasels. The tail is long and furry, marked in some species with spots. The pouch opens downwards, and the litter may number as many as six, the number of teats in the pouch. Besides several species from New Guinea, Australia has five, of which we may take as typical-

D. viverrinus, the commonest, a brown or black animal like a marten and covered with white spots. It is found in New South Wales and Tasmania. It lives largely in trees, feeding upon birds and their eggs; but although it gets up a tree fast enough when put up by dogs, I have observed great clumsiness in its movements, and it is a poorer climber by far than the opossums - which is partly accounted for by the fact that it derives no aid from the non-prehensile, bristly tail. It gives birth to four or five 
young at a time, carrying them a short while only in the pouch.

Another species is grey, spotted with black and having a black tail, while there is a small Queensland member of the family with very peculiar hind-feet.

From the neck of one of the commoner species, which I found in extreme convulsions, I took on one occasion two large bush ticks, which had so exhausted the unfortunate beast that it died of its injuries within a few hours.

These animals prey largely on quail and other ground birds, and their manœuvres on the warpath are an excellent lesson in practical stalking.

The so-called Pouched Mice-which are quite distinct from the aforementioned true rodents, attacking and killing them at every opportunity-come under three genera, Phascologale with a dozen Australian species and others from New Guinea, Sminthopsis with four species, and Antechinus with only one.

The pouch is practically absent in these little animals, none of which, tail and all, measure over eighteen inches, some being less than one-third that size. In some it is replaced by a mere fold of skin or bristles.

The teeth point to an insect diet quite at variance with the fierce character assigned to the family by the Rev. J. G. Wood and other popular writers. I have handled several, but never found them in the least aggressive.

Three or four species will serve as types.

Phascologale flavipes is a rapid climber, often seen abroad in the day. It will produce as many as ten at a birth.

$P$. penicillata, the Tapoa-tafa, is an agile little creature, not unlike a rat in appearance. In colouring it is of a dirty white with a black and bushy tail, the latter being long but not prehensile.

$P$. calura, a beautiful species, has grey fur above and 
white beneath. The tail is black and bushy. Like the rest of the family, it attacks mice readily, and can be fed on them in captivity.

There are ten teats in the pouch, and eight young go to the litter.

Sminthopsis, with narrow hind-feet, is not an arboreal genus like the last, but lives on the ground, rarely climbing trees even when hotly pursued.

A type of the genus is-

S. virgince, found only near the Herbert River, Queensland, and one of the rarest species. Lumholtz presented a handsome specimen to the museum at Christiania having a black stripe along the back of the head.

Antechinus laniger, a long-legged, jumping pouchedmouse, has no first toe in the hind-foot, yet there are many pictures in books in which this four-toed creature is perched among the branches.

Perching with four toes only and no opposable thumb would be rather difficult. It is, like the rest, insectivorous.

Myrmecobius fasciatus, or the Banded Ant-Eater, has no pouch, but in its place a fold of long hairs that admirably protect through their helpless stage its four young. The fur is short and reddish, toning off to yellow below, and with seven white bands along the back. Its long, serrated tongue enables it to exploit ants' nests to advantage and feed to repletion on its favourite food; besides which, the Yelkie, as the natives call it near Perth, is said to attack snakes. At any rate, its mouth is furnished with fifty-four teeth, ${ }^{1}$ which it never uses, however, when handled, being a most docile creature and much in favour as a pet with children of Western Australia, to which

1 These are 14 incisors, 4 canines, 12 premolars, and 24 true molars. 
colony it is practically confined. Though it lives mostly on the ground, it gets nimbly enough up a tree when chased. With the tail, it measures about a foot and a half.

\section{Dasyures}

Tasmanian Wolf . Thylacinus cynocephalus (T.)

Tasmanian Devil.$\{$. breviceps (T.) Sarcophitus ursinus (T.)

$\begin{aligned} & \text { Native Cats . . . }\left\{\begin{array}{l}\text { Dasyurus viverrinus (N. S. W., T.) } \\ \text { D. geoffroyi (Q.) } \\ \text { D. hallucatus (Q.) } \\ \text { D. maculatus } \\ \text { D. gracitis }\end{array}\right. \\ & \text { Pouched Mice . Phascologale cristicaudata } \\ & \text { P. apicalis (W. A.) } \\ & \text { P. swainsonii (T.) } \\ & \text { P. minima } \\ & \text { P. flavipes } \\ & \text { P. minutissima } \\ & \text { P. penicillata } \\ & \text { P. calura } \\ & \text { Sminthopsis crassicaudata (W. A ) } \\ & \text { S. murina } \\ & \text { S. leucopus } \\ & \text { S. virgina (Q.) } \\ & \text { Antechinus laniger }\end{aligned}$

Banded Ant-Eater. Myrmecobius fasciatus (W. A.) 


\section{CHAPTER VI \\ THE POUCHED MOLE}

The Pouched Mole (Notoryctes typhlops), or Urquamata, was only discovered in South Australia quite recentlyabout five years ago, I believe-in the immediate neighbourhood of Lake Eyre. It has been compared by naturalists with the Golden Moles of Africa, and one American anatomist would have included it, though wrongly, with the placental types. With its powerful legs and claws, this insectivorous animal burrows in the sand more rapidly even than the echidna, and its movement, with the back partly exposed, has been happily compared by Mr. Lydekker ${ }^{1}$ to that of a porpoise in a smooth sea.

This little mole, which only measures with its short tail about six inches, has reddish fur.

As the echidna disappears in the warmer season, so is the pouched mole exceedingly scarce in winter time.

The Pouched Mole. . . . . Notoryctes typhtops

${ }^{1}$ Marsupials and Monotremes (Allen's Naturalist's Library). 


\section{PART III. - THE MONOTREMES}

\section{INTRODUCTORY}

The Monotremes are the very lowest creatures in the mammalian scale; and it seems almost possible that they will one day be treated as a separate order, though it is not for a small handbook like the present to depart from the orthodox treatment of the subject. Of course, they come in a sense under the category of mammals; but, on the other hand, they fulfil the conditions in a manner far from satisfactory. The reproduction of the young is by eggs; and the liquid on which they are nourished is not the true milk of mammals, being neither secreted nor taken in the same manner, indeed it is pumped like perspiration through the pores of the skin, which in the echidna forms a pouch. The eggs are meroblastic ${ }^{1}$ like those of birds.

The casual observer of Nature's household would scarcely connect the beautiful birds with the torpid reptiles; would scarcely think that the majestic albatross and sluggish adder owe their existence to a common reptilian ancestor.

1 Glossary. 
Yet such is indeed the case, and the platypus, with characters derived from both orders, is in a sense a link between the two.

These monotremes reproduce their young by eggs which are incubated by the platypus, and hatched out in the pouch by the echidna. There are further bird analogies in certain of the functional organs, which discharge into a common canal, in the separation of certain bones in the skull, and in the presence of a bony bridge between the collar-bones that bears a close resemblance to the "merry thought" found in birds.

They resemble the marsupials in the possession of the epi-pubic marsupial bones, while the echidna has a pouch as well; also in the simple nature of the brain and absence of corpus callosum.

And as their normal temperature is less than $80^{\circ} \mathrm{F}$. we may regard these extraordinary creatures as comparatively cold-blooded.

The two genera have little in common so far as habits and appearance go, though the male has in each case the much discussed spur on the hind foot.

These monotremes, then, of which I proceed to consider individually the two representatives, combine characters of mammals, birds, and reptiles. In their reproduction they are not viviparous like the mammals, not ovoviviparous like some fish and reptiles, but oviparous like birds. 


\section{THE DUCK-BILLED PLATYPUS}

(Ornithorhynchus paradoxus : or Duck Mole - in the native dialects, Mallangong, Tambreet, \&c.)

An animal that puzzled such anatomists as Owen, St. Hilaire, Meckel, and Bennett, may be expected to present some striking characters; and indeed the confusion occasioned by the appearance and anatomy of this singular object has not yet subsided. The learned gentlemen to whom were consigned the first stuffed specimens that reached this country declared them to be manufactured, after the fashion of Buckland's "mermaids"; and with some excuse, seeing that no other region as yet explored had ever yielded so grotesque a combination of bird, beast, and fish, with its aquatic habits, beaver-like fur, webbed fore-feet, hind-feet made for tunnelling like those of the mole, and the bill of a duck.

It is chiefly, however, in the dried specimens that these characters, the last-named more particularly, are apparent. For these miserable effigies, rigid as mummies, with the shrunken feet and brittle bill, give no idea of the beautiful, glossy creature that sports in the sluggish streams. Here is no trace of the delicate membrane that in the natural state fringes the semi-transparent, nervous 
muzzle; no sign of the expanding cheek-pouches, resembling those of monkeys, and oft crammed with water insects; and but the poorest remnant of the patch of grey skin that protects the base of the bill. A hundred other features of beauty all vanished with that volley of shot!

The wooden hide of the specimen gives no suggestion of the beautiful looseness of skin that resists even shot,

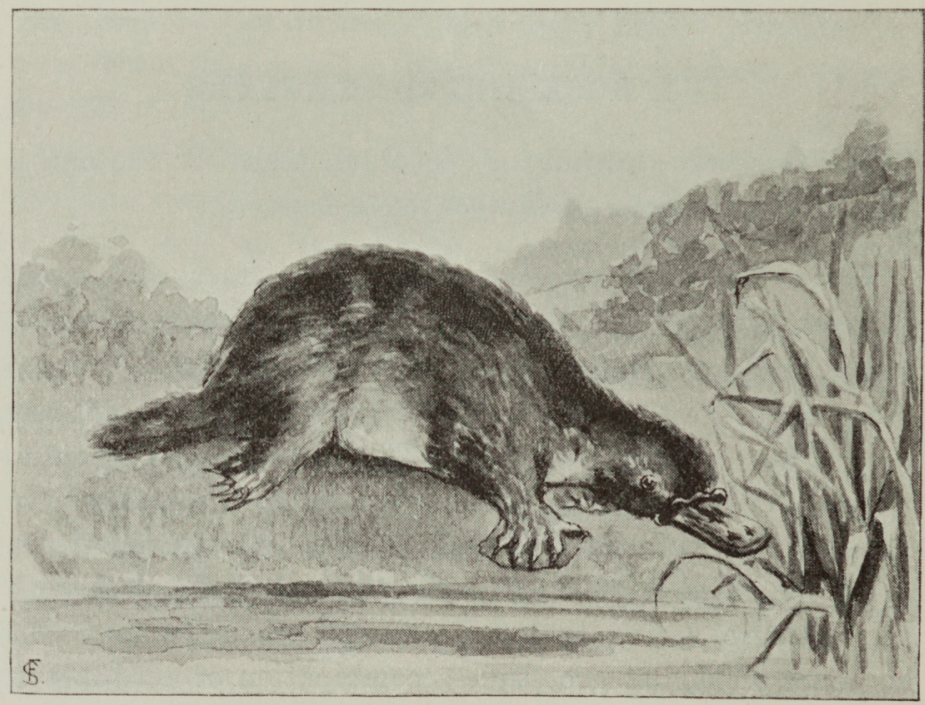

Platypus

which rarely pierce it, though striking with sufficient force to stun the animal.

It were better, indeed, to turn for some reliable account of the platypus to Australian anatomists, who describe its characters during life and immediately after death, and not, as most European writers have necessarily done, from these dried specimens.

Of the animal's external peculiarities, the most interest- 
ing perhaps are the feet, the spur on the hind leg, and the so-called bill. The fore-feet are strongly webbed for swimming, the hind-feet turned back, like the mole's, for tunnelling.

The spur inside the male's hind leg has not yet, so far as its functions go, been satisfactorily accounted for. The theory that it can at all times inflict a poisonous wound was disproved by Bennett, who found from personal experiment that, not only does the animal make no attempt, when handled, to use this spur as a weapon of offence or defence, but that the latter, even when inserted in the flesh, excites no symptoms of poisoning or unusual inflammation.

Some regarded it, and still do so, as connected in some way or other with the period of courtship, the opinion being that then at all events it communicated with a poison duct. Nothing, however, has been proved up to the present.

It may be mentioned that the young females show traces of a rudimentary spur, which disappears at an early stage.

So also do the teeth of both sexes. In the bill of the young platypus, the pink transparency of which gives place ere long to a dull grey colour, are eight little functional teeth, replaced in the adult by as many horny plates. A beautiful section, preserved in spirit and showing these early teeth, may be seen on the ground floor of the Cromwell Road Museum.

But the most debated point in connection with the lifehistory of the platypus was its mode of reproduction, now proved to be, as often previously suggested, by eggs. This the aboriginals, whose veracity is not beyond question, had for some time asserted to be the case, but the notion was rejected by Owen and Bennett, and ridiculed by more recent writers, one of whom ${ }^{1}$ says: "As to the idea of

1 Wheelwright: Wanderings of a Bush Naturalist (1865). 
its laying eggs, that has long been exploded; they are clearly mammals, for the female has teats."

Which is incorrect, for the female has no teats.

A gain, in a very recent contribution on the subject, Mr. Nicol ${ }^{1}$ says: "The natives in various parts of the country have exhibited their ignorance of the platypus by asserting that the young are produced from eggs."

Yet in the year 1884, some time, I believe, before the appearance in print of the work last quoted, Mr. Caldwell, who went out from Cambridge for the purpose, finally settled this vexed question, proving that the eggs, enclosed in a small white shell, are two in number. The Hon. Walter Rothschild exhibited some very small examples of these eggs some time ago at a meeting of the Zoological Society, which were taken from the burrow of a platypus, and which are now in that gentleman's museum at Tring. The eggs formerly sent to this country as those of the platypus belonged unmistakably to river tortoises. The platypus, as already mentioned, incubates its eggs much as a bird would, while those of the echidna are hatched by the heat of the pouch.

The animal measures, when full grown, and including the tail, about two feet.

The prevailing colour of the coarse outer fur is darkbrown, but the finer fur beneath, with which, like the seal and otter, it is afflicted, is of lighter hue.

But for this doubtful, blessing it might still freely gambol in its native streams as darkness falls swiftly over the southern landscape, and might otherwise go in peace and multiply, bird-like, after its kind; for it is of the few indigenous animals not eaten by the natives. Alas, for the greed of the furrier and the vanity of his customers ! The pot-hunter camps beside the most secluded waters, and 
with his murderous weapon ever at his shoulder, soon learns the secret of shooting the agile and beautiful animal that at first baffles him by diving at the flash of the gun. It is a wicked slaughter, for thirty or forty of the animals must die to make even a small rug.

I recollect a very handsome rug of this description fetching but eight guineas at a sale in Pitt Street, Sydney; while the lucky purchaser disposed of it, so at least the report went, at the Australia Hotel only a week later for twelve times the sum. The rich under-fur is also manufactured into muffs, tippets, and other adjuncts to vanity.

The platypus is thus becoming lamentably scarce, and many a beautiful stream in Victoria and Tasmania, where whilom it rooted up the larvæ or engulfed the floating gnat, knows it no longer. It is a sensitive, nervous creature, having the fifth pair of nerves larger, as Meckel pointed out, than those in man.

It was a simple tale enough, the life-history of the "Duck-Mole," until the white man came along. Exceedingly difficult to secure, even with the unerring spear, it escaped more than any other creature the omnivorous aboriginals. Nor do they eat it, as they do most else, for travellers have had some difficulty in inducing them to dig it out of the burrow.

So it lived in peace, constructing at leisure the thirty or forty feet of run, one entrance beneath, the other above the surface, and terminating in the oval, grass-lined nest, which is carefully placed some distance above flood-level. Here the female would deposit and incubate her two white eggs, and a happy time the family soon had of it, sleeping the livelong day rolled up in a ball, and emerging at sundown, the dam instructing her cubs in the arts of swimming and the chase.

But now the halcyon days are over, and the poor little 
beasts have aroused the desires of a new and terrible enemy, whose arms are far-reaching as his greed is without bounds.

Surely their days are numbered in the land!

Numbers are shot each week, though only rarely is one trapped or caught with baited hooks. Still, cases of the latter are on record. In captivity, they do not seem successful, as it is difficult to keep them provided with the right food. Even in Australian zoological collections, they occur only in the glass case.

\section{THE ECHIDNAS.}

(Echidna setosa and E. hystrix: aboriginal, Kogra.)

The Echidna - the long-haired Tasmanian animal ( $E$. setosa) would seem to be merely a variety adapted to the colder climate - is an ant-eater of singular appearance. The head is prolonged to a curious pencil-like snout which, unlike that of most ant-eaters, is either perfectly straight or curved slightly upwards. It cannot open its jaws, but through this snout it thrusts its long tongue, tipped with a gummy secretion, and thus secures the ants or other insects which it seeks chiefly at night. This insect-eater is, by way of compensation, a prey to two most vigorous fleas peculiarly its own, one of which, having lost its jumping power, never leaves it. Similarly, Lumholtz described a new and peculiar tapeworm in the Koala.

Both the tongue and palate are covered with spines, but there are no teeth, not even the horny plates found in the mouth of the platypus.

Like the platypus, it has very tiny eyes, but they are darker in colour than those of that animal. The skin is tough and covered with sharp spines that (in E. hystrix) protrude from the coarse, black hair and hide the short 
tail. Great burrowers, with the aid of their short, strong legs and solid nails, they are practically the hedgehogs of Australia, and the rapidity with which they can burrow in the softer soils is remarkable.

There seems to be a distinct genus in New Guinea, containing a three-toed species, but in Australia only one genus is recognised.

Their reproduction is, like that of the platypus, by means of eggs, one of which is preserved at the Cromwell Road Museum. These, however, the female carries in her pouch; and when the young are presently hatched, she pumps the milky secretion into the young one's mouth through glands like those of the platypus.

Meckel recognised the echidna as both oviparous and milk-giving; but St. Hilaire seems to have regarded both notions as preposterous. The solution of the question was left to Mr. Caldwell, who studied the habits of this animal and the platypus during the same expeditions. The echidna disappears in some unaccountable way during the hotter months, hibernating, if the expression is admissible, in summer.

The hind-ioot of the male is provided with the same kind of spur as is found in the duck-bill, and the scientific name (Echidna is the equivalent of viper) would imply poisonous properties. I have handled many a live echidna, the correct way, to avoid the spines, being by the hind-leg, but forebore to try the spur; for I must confess that my enthusiasm for the curiosities of natural history stops short at these interesting experiments on my own person. Such things are a matter of taste. Bennett, for instance, whose enthusiasm in matters of this sort was unbounded, gives an animated account ${ }^{1}$ of his lively experiences with a medusa which, for the novelty of the thing and in the interests of 1 Wanderings in New South Wales (vol. i., p. 10). 
scientific research, he had encouraged to sting him in the arm.

Unlike the platypus, the flesh of this animal is greatly in favour with the aboriginals, and has, when roasted in its skin, been pronounced excellent by settlers. It is well provided with its favourite food in Australia, a land in which the difficulty, is not how to find ants, but how to avoid them.

* $\quad * \quad$ * $\quad$ * $\quad$ * $\quad$ *

This concludes the mammals. Either some fresh and valuable sources of wealth have yet to be discovered in that wonderful land, or Australian indigenous animals are singularly useless to man.

As the continent is in many parts overstocked with cattle and sheep, meat is cheap, and the native beasts are little eaten save in the lonely parts of the bush.

Kangaroo-tail soup is only a faute de mieux where there is no ox-tail to be had; and only after a hard day's work could civilised men appreciate a "steamer" of kangaroo meat and bacon fat.

The skins, as already mentioned, are either spoilt by shot or careless handling, or neglected altogether.

In the foregoing pages I have confined myself necessarily to the indigenous mammalia, giving no account of the acclimatised cattle, horses and sheep, the hated camels in Centralia, the zebu-like buffaloes introduced from Timor to Baffles Bay on the north coast, the alpaca imported, against the laws of that country, from Peru, the horses run so wild in Queensland that whole mobs of them have to be shot down, or that worst plague of all, the rabbit. It is an old, old story now, the ill-judged introduction of this destructive and prolific rodent by some homesick 
settler, who forgot that the snakes would be about the only check on its increase.

This blunder has already cost Australian Governments millions sterling, to say nothing of private expenditure and losses of the squatters themselves; and the evil seems as far from remedy as ever.

It was rumoured at one time that a nephew of the late M. Pasteur had solved the difficulty by a proposal to liberate a number of male rabbits inoculated with virus, and I believe he visited Australia with the object of conducting a series of experiments. Whether, however, his suggestions were not given proper trial, or whether some other obstacle arose, the rabbits are still thriving, and the unfortunate squatters are paying heavily for the folly of those gone before.

In New Zealand, where they spread from an original hutch of seven landed at Invercargill, these pests seem to have been kept more within bounds by the strict edicts against the ownership of rabbits, a Government bonus of one halfpenny on every skin exported, and liberal distribution of wheat saturated with carbon bisulphide. And it almost looks as if the cloud might yet show a silver lining, for good rabbit fur, used by hatters, fetches five shillings a pound, the pelt boils down for size, and the waste makes first-rate manure for hop-gardens.

Nor did I give any account in the foregoing of the black-maned "Bunyip" and "Mindai" of Lake George and elsewhere. These fabulous creatures rank with the seaserpent. 

BIRDS 



\section{INTRODUCTORY}

In the foregoing pages we have seen that the mammals of Australia number not much over one hundred and fifty.

The birds are, however, a much stronger group, comprising some six or seven hundred species, five hundred of which, in round numbers, are found nowhere else. Tasmania has scarcely two hundred.

In the matter of brilliant colouring and exceedingly interesting habits, these Australian birds make up much of what they lack in voice. The swallows are mute; nor does the cuckoo's note herald the coming spring-time.

The brilliant plumage of the handsome King Parrot and exquisite Crimson-winged Lory would put any of our birds, save perhaps the burnished kingfisher, to shame; on the other hand, who that has lived in both countries would not willingly forego the glories of all these gaudy screamers for one song from the sober skylark or nightingale!

In the following pages it is only proposed to give a brief sketch of the habits and peculiarities of the chief families; to acquaint the reader with those quaint feathered architects the bower-builders, megapodes, mutton birds, pardalotes, and fairy-martins; or such incomparable 
mimics as the lyre-bird and laughing jackass. Cranes dancing like dervishes and wood-swallows swarming like bees also occur in the list.

Indeed, the only other of our colonies with a show of birds surpassing in interest those of Australia is that of New Zealand. In that remarkable country, fifty-eight out of the sixty-nine families of land birds are found nowhere else-not, as might be expected all wingless birds, for these number only about twenty, including four species of apteryx, a duck, a ground parrot, the notornis, and a dozen (ocydromus) wood-hens.

Who can say what law restrains the strong winged birds of Australia from visiting Maoriland, or some of the grotesque birds of the latter region-the mutton-eating kea, for instance, once strictest of vegetarians, ${ }^{1}$ or the shorehunting Anarhynchus with its comical bill turned to the right-from crossing the sea westward!

Quien sabe!

Regarding the subject rather from the standpoint of the visitor newly arrived on those coasts, I propose considering first the waterfowl and waders.

1 As another instance of new tastes, Lumholtz mentions a Wallaroo that turned flesh-eater. 


\section{PART I.-WATERFOWL}

\section{THE WATERFOWL}

\section{Sea Birds}

OF the waterfowl or Swimming-Birds (Natatores), the sea birds are those which are naturally first to greet the visitor, and their presence does much to relieve the monotony of the approach to the bleak south-west coast.

From the great Albatrosses and Molly Hawks down to the graceful little Gulls, they usually follow in the wake of steamers to the very gates of Port Phillip.

Before all in size and beauty comes the great Wandering Albatross (Diomedea exulans), grandest among all ocean birds.

The first albatross seen on the outward voyage is always an event, for it points to the approaching end of the weary journey; and those who have not before visited those southern seas are usually content to gaze by the hour on that magnificent sweeping flight in which the bird keeps up with steamers going fifteen knots for days together and without apparent effort, describing, moreover, great circles that must at least treble the distance.

Bennett gives excellent accounts of this bird in several 
works, ${ }^{1}$ though, as Gould points out, ${ }^{2}$ the correctness of his statements has been called in question; and indeed I have myself repeatedly seen it fly right in the eye of the wind, a feat which Bennett denies it. I have wasted many a camera-plate, too, in the vain hope of getting a picture of the beautiful bird with the twelve-foot spread of wings and the powerful yellow bill-six inches of it, and strongly hooked-and bright eyes. Yet slowly as it sails alongside, buoyed up by the air cells beneath its plumage, it is exceedingly difficult to "snap," and the amateur may be cautioned to keep his plates for better work.

Shorn of its beautiful plumage, the albatross is indeed, as revealed by the skeletons in the museum, a very indifferent-looking fowl.

Though essentially built for breezy weather, and but a poor performer during a calm, it is nonsense to think that, as also alleged of its smaller kindred the Petrels, this bird takes a delight in storms. It must necessarily have more trouble in bad weather in obtaining a sufficiency of floating squid, its principal food. Even so, the little Storm Petrels, or "Mother Carey's Chickens," of our own coast hover round ships for protection from the storm which their instinct warns them is at hand.

The great Albatross is, however, but rarely seen so far north as Sydney, its place being taken by various smaller and darker species, notably $D$. fuliginosa, known inele. gantly as the "Stinkpot," and the "Molly Hawks" and "Yellow Bills," as they are called. The Molly Hawk comes wheeling round steamers as soon as they leave the Heads, though I never saw one inside Port Jackson even on the stormiest days. Not that it is by any means

${ }^{1}$ Gatherings of a Naturalist ( p. 70), and Wanderings in New South Wales (App.).

${ }^{2}$ Birds of Australia (vol. ii., p. 424). 
a shy bird, for I recollect on one fishing outing one of these birds being tempted with pieces of fish so close to the boat, that a member of the party, a very indifferent shot, put a rifle ball right through it, and it is now, to the best of my knowledge, adorning a hall door in London.

On another occasion I regret to say that I helped to catch one of the poor birds with a baited hook, and we subsequently hauled it aboard with some trouble, the barbed steel fast in its powerful yellow bill, its feet planted firmly before it in the water, and its neck partly dislocated by the strain.

On being dropped on deck it vomited violently. Sportsmen are curious animals indeed. I have hooked thousands of fish without a pang, consoling myself with the reflection that they are creatures of lowly organisation. But the only bird I ever captured in this way disgusted me with the thought of my own cruelty. It seemed so unnatural? Sometimes, like the albatross, and especially with a breeze astern, these birds, I am told, rise high in the air when hooked, when the "sport" must resemble kite-flying.

There are others of the Petrel family related to the Albatross, for which, with one exception, mere mention will suffice, namely the Giant Petrel (Ossifraga) of Tasmania, the Diving Petrel (Haladroma) or "Tee-Tee," of the Maoris, which lacks the hind-toe of the rest, the Prions, and five Storm Petrels.

The exception, which deserves a few words to itself on account of its remarkable habits and commercial value, is the Mutton Bird (Nectris brevicaudus), of which I saw vast numbers on Cape Barron Islands in Bass' Straits, also the home of a remarkable goose. On this island the Mutton Bird burrows and breeds and is slaughtered in its thousands, without any apparent impression being made on its 
numbers, for the sake of its down, as well as the eggs and oil.

Owing to the great length of wing they are, like their kinsman the albatross, prevented from rising from the ground without a run, and advantage is taken of this to trap them in pitfalls dug in their favourite tracks. These are soon filled to overflowing and the hapless birds butchered wholesale. As it takes five-and-twenty birds to furnish a pound of feathers worth twopence, some idea may be formed of the great destruction that goes on. Yet in spite of this, as well as the rifling of the nests for eggs and young birds, the latter being squeezed into oil-receivers, they seem to come back each year in undiminished numbers. The number of eggs gathered is also enormous; and these eggs have the peculiarity of never getting perfectly hard, however long they are boiled.

They are occasionally found on the ground beneath some sheltering clump of a shore plant common on those islands and resembling barilla. The egg-collectors meet with an occasional mishap from the poisonous snakes, which also like an occasional meal of poached eggs. So long are the wings of these valuable birds, that they are obliged, like the albatross, to throw themselves from the cliffs when taking flight.

\section{Gulls and Terns, \&c.}

The Gulls (Larida), though exceedingly nimerous, are of three kinds only. So bold are they as to snatch pieces of bait from the gunwale, and this may be attributed partly to the kindness of colonials towards the birds, partly perhaps to the latter having not yet learnt the ways of man.

The three species in question are the Great Gull (Larus pacificus) of the more southern coasts, the Little Gull 
(Bruchigavia), of wider distribution, and a species allied to the latter named after Gould, and found only on the north Queensland coast. I noticed that these gulls were generally more graceful than their northern representatives, and flew as a rule at a greater height.

There is also a Skua (Stercorarius), on those coasts, identical, so far as I could see, with the "Jack Hurry" of Cornish fisher-folk; with the same depraved tastes, too, swooping in the same way on the gulls as they return to their nestlings crammed with fish, and compelling them to disgorge the recently-caught herring or garfish, which it deftly catches ere it lights on the water.

The Terns (Sternidce), are near a score, including the identical Caspian Tern of European seas, three species of Thalasseus and Sterna, one Little Tern (Sternula), a Marsh Tern (Hydrocketidon), which breeds among the swamps, and the Sooty Tern (Onychoprion) familiar to outwardbound travellers from the Red Sea to Sydney. One of the terns lays its single egg in the hollow of a palm leaf.

Of Noddies, which look like terns deprived of their long, pointed tail, there are four species, three of Anous, and one of Procelsterna, known as the Gray Noddy. They breed on Houtmann's Abrolhos (W.A.) and similar islets.

There are likewise four Grebes (Podicipida), one (P. gularis), found on every coast, the others in the south only. The Tippet Grebe discards its beautiful black and white frill, and $P$. nestor its attractive head plumes, after the breeding season, these aids to vanity being merely assumed at the time of courtship. Unlike our own grebes, which they otherwise closely resemble in habits, they build a floating, boat-like nest. 


\section{The Pelicans, Gannets, \&c.}

This group has some important and interesting representatives in Australian seas, and among them are the water-birds that first attract the notice of the visitor approaching the continent from the north-east in the British India steamers, the Frigate Bird (Tachypetes) and Tropic, or Boatswain, Bird (Phaëton).

The former of these I last saw at the northern extremity of the beautiful Albany Pass just after we had dipped our flag to Mr. Jardine according to custom. Here, like the skuas, several of them were pouncing on the smaller fowl and despoiling them of their fish. I have even seen them attack gannets in this way, the latter being cowardly birds for all their size, and showing as a rule no reluctance to drop their booty and seek safety in the water. The white breast and elegant, forked tail-feathers of these birds make them conspicuous at a great altitude.

They have been observed to chase flying-fish and even to tear strips of coloured bunting from the masthead, ${ }^{1}$ but I never saw them do either. There are two species, both of which lay a single egg in a rudely-constructed nest on the shores of various islets within the Great Barrier. The bird is not much persecuted, though the feathers are in some little request for ornamental purposes and the fat is regarded as a specific against sciatica.

Less common than the preceding is the exquisite pale pink Tropic Bird (Phaëton), which has flaming red tailfeathers. Beside their handsome parents the young birds are dull indeed, lacking both the pink plumage and red tail-feathers.

The last-named are greatly esteemed by warriors of the South Sea Islanders as head ornaments.

${ }^{1}$ Bennett: Gatherings of a Naturalist (p. 82). 
This graceful bird is a welcome sight indeed as it hovers far overhead, its colouring distinguishable only with the aid of the glass, uttering the shrill whistling that has obtained for it from sailors the appropriate name of "Boatswain."

Among the remaining members of this group, we have the true Pelican (Pelecanus), a large white bird with formidable yellow bill and deep pouch, generally plentiful in the southern creeks and nesting on the shore.

Five Cormorants there are, all peculiar to Australia, namely, the Shag (Phalacrocorax), the largest of all, which is particularly abundant in Tasmania. Here, on the rocky cliffs, it constructs its seaweed nest, in which it lays the two bluish eggs. I have seen it in trees far up the Hawkesbury and other southern rivers, and always found it an exceedingly difficult bird to shoot, as it either rises rapidly out of range or else dives like lightning, reappearing in a second or two in some unexpected quarter, a process repeated so long as it is watched by any. one armed, though if one is out fishing and without guns, the wretched bird will be as tame as your own fowls.

Another species (P.varius) is not found so far up the rivers, and nests in trees along the shore.

A third (P. leucogaster) occurs principally in 'lasmania, but is also met with in small numbers in the bays and creeks of the opposite coast.

The Little Cormorant ( $P$. melanoleucus) is a smaller and more solitary bird than the rest, being found in single pairs among the trees that overhang tidal rivers, though just in the nesting season six or eight pairs will assemble in the same tree. These colonies are probably formed for defence against hawks and other enemies. The young of this species have the under surface of a purer white than in the rest. 
The Little Black Cormorant ( $P$. stictocephalus) is met with but little on the coast, preferring more secluded haunts up the rivers and on the lagoons up country.

Harder to shoot even than the Shag is the New Holland Darter (Plotus) or "Snake Bird," which, as soon as its keen yellow eye detects the gun, instantly dives, submerging all but the head and slender neck, which make about as satisfactory a target as a distant snake. About the end of March these darters assemble in large companies among the trees bordering the southern rivers, and here they nest, laying three brittle white eggs, the parents sharing in the incubation. The plumage is of a handsome metallic green, banded with white.

And lastly come the Gannets (Sula), known, so stupid are they, as "Boobies," and four in number. Like our own Solan Goose, they swoop with folded wings on the mackerel and other surface fish. Three of them, including the large Red-legged species, are practically confined to the coast of North Queensland, and there is a fourth of more general distribution.

\section{The Penguins}

The grotesque Penguins (Spheniscida) are the only remaining family of sea-birds. At the beginning of the present year a number of people visited the Zoological Gardens at Regent's Park to see two little orphan King Penguins (Aptenodyx pennantii) that had come all the way from Macquarie Island in the South Pacific. Bereft of their parents on the voyage, one of the poor little birds was not long in following, though its brother is still doing well.

Their particular interest lay in their not having yet assumed the white waistcoat of the adult stage, as their plumage was of a uniform buff colour. 
These Penguins always maintain the upright position, standing on the whole foot and not on tiptoe, even when incubating, a duty shared by both parents.

It is said, though I have not seen it, that few sights are more ludicrous than the way in which the female, when

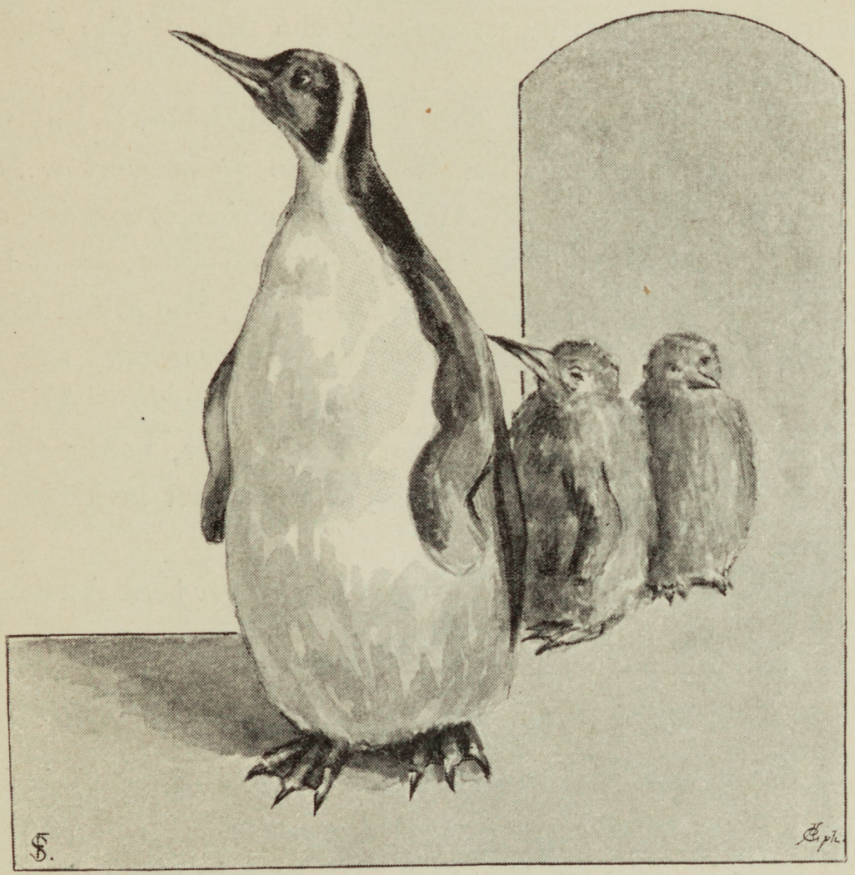

Penguins.

anxious for a dip in the sea, bowls the egg along to her watchful mate, who in turn stands over it.

Indeed, I never got far enough south to see the King Penguins, but I have seen outlying rocks near Tasmania covered with other kinds (probably Fairy Penguins), and when a volley was fired to disturb them, they simply 
shuffled to the beetling edge and tumbled into the water, not, as one writer says, throwing themselves flat.

To all intents and purposes they are wingless birds; but the wings are most efficient swimming paddles, the keel of the breast-bone, with which they are connected, being far more highly developed than in the ostrich and emu. In fact, there is a strange resemblance between these leathery, inflexible wings and the fins of the dugong and manatee.

The other penguins at the Zoo, which when fed attract so many visitors to the Fish House, are at present a New Zealand (Eudyptes), and an African (Spheniscus) species, and are distinguished from the "King" by the short, stout bill.

The Fairy Penguin (Eudyptula undina), the allied Little Penguin, and the Crested Penguin (Chrysocoma) are all found at times on the islets in Bass' Strait. All the Penguins occur in the southern hemisphere, being represented, if the term is admissible, in northern latitudes by the Auks.

It will be noticed in the foregoing chapter that Australia has not a single puffin or guillemot.

\section{Ducks and Geese}

Australian waterfowl are a large order, and Victoria has nearly eighty kinds, without the sea-birds. The natives subsist very largely on this rich diet, and in some districts they employ a very ingenious net which is held across the stream by two of their number concealed in trees on either bank. The others then make a détour and drive the ducks and other fowl up stream, and as soon as they strike the net, the latter is dropped and the birds drowned beneath it.

The typical species only of the Anatida need be considered here.

The Black Swan (Chenopis atrata) - no true swan, by the 
way - is found sparingly in the southern colonies, particularly in Western Australia. The Rev. J. G. Wood ${ }^{1}$ says "this bird is found in Australia and Jamaica," but Tasmania must have been meant.

Its presence in English parks, where it breeds freely, has familiarised every one with the black plumage and red beak; but there are few opportunities of observing the sharp contrast offered by the white wings as it flies overhead uttering at short intervals its soft call-note. In its native swamps it nests just before Christmas, the eight or nine pale green eggs being slightly smaller than those of the true swan. It is said that in England these birds have reared two broods in the year. The young birds are not bad eating. In Tasmania the bird is getting very scarce.

As Chenopis is no true swan, so is Anseranas melaroleuca no true goose, though it goes by that name. It is a true water-bird, however, and by no means rare in Queensland. I have shot this "semi-palmated" bird, known locally as "Magpie Goose," in Cleveland Bay and further north, but it takes some killing. The hooked beak is surmounted by a knob, but the chief interest about its anatomy is the treble fold of its abnormally convoluted windpipe.

Another pseudo-goose is Cereopsis, the Cape Barron Goose, so-called after the island in Bass' Strait which it inhabits. As a goose, it is not a success, seldom if ever taking to the water. I am bound to confess that I never met with it alive out of our own Zoological Gardens, and have therefore had no opportunity of tasting its flesh, which is said to be excellent. It is a pugnacious bird, and one author $^{2}$ mentions how a pair set a farmyard by the ears.

1 Illustrated Natural History (vol. ii., p. 727).

${ }^{2}$ Bush Wanderings of a Naturalist (p. 71). 
It occurs sparingly in Victoria, where it is known as the Grey Goose.

South Australia is par excellence the home of the Wood Duck (Chlamydochen), though it is often found in New South Wales, but not in Tasmania. Its voice is loud and unpleasing, and may be heard from the hollow tree in which it nests. The bird is much esteemed as food.

Australia has also a Teal (Anas punctata), a larger Speckled Teal (A. novosa), and a Shoveller (Spatula rhynchotis), the latter being specifically distinct from the "Spoony" (S. clypeata) of Europe, which also visits these southern shores.

The Pink-Eyed Duck (Malacorhynchus) is found only in Australia, where it keeps to the southern districts; and the Whistling Tree Duck (Dendrocygna), so-called from the peculiar whistling note it utters on the wing, has an allied species, which also whistles, on the north-west coast.

The Musk Duck (Biziura lobata), with a strong odour in the breeding season, is only found in the southern colonies. Gould happily compares its hollow note to the sound of water falling down a well. Larger than most ducks, it is nevertheless hard to shoot on account of its rapid diving, often with the young one (like the grebes) clinging to its back. 


\section{PART II.-WADING BIRDS}

\section{THE WADERS}

\section{Herons, Bitterns and Rails}

Two or three chapters must now be devoted to the important order of the Grallatores. Reserving most of our space for such families as are typically Australian, we need devote but a few lines to the twelve herons and egrets, including the exquisite blue and white Reef Heron (Demiegretta) which nests along the east coast. The most interesting perhaps is the Nankeen Night Heron (Nycticorax), which is nearly related to the night heron of Europe and distinguished by a crest of three narrow white feathers. It is fairly plentiful in the northern districts of New South Wales, where it nests in company with other species about Christmas time, laying three pale-green eggs. It feeds, as its name implies, entirely by night, passing the day in the thickest trees, from which, however, it is easily started, when it flies off with its shapely head drawn well back between the shoulders and pitches in a neighbouring tree.

To the Ardeidce of Australia there also belong five Bitterns, nocturnal birds like our own-if, indeed, this can 
still, keepers and pot-hunters notwithstanding, be reckoned among British birds. All day the Australian bitterns sleep among the reeds, the three Mangrove Bitterns (Butoroides), which wander by night among the swamps feeding on crabs and molluses, and the Minute Bittern (Ardetta pusilla), small and rare as its European ally the Little Bittern.

Of the sixteen Australian Rails, all but three are to be found elsewhere. The Chestnut-bellied Rail (Eulabeornis castaneiventris), which is often seen running swiftly among the mangroves that fringe the northern rivers, on the banks of which it lays its long, pink, speckled eggs; the "Native Hen" (Tribonyx mortieri), and "Moor Hen" (T. ventralis) of the colonists, the former occurring in Tasmania as well, are the only rails peculiar to the region. The last-named is most uncertain in its goings and comings, disappearing and returning in the most unaccountable manner; and Gould remarks that the aboriginals of Western Australia called it the "White Man's Bird," thinking, as one of its visits coincided with the arrival of some early settlers, that they were in some way associated.

\section{The Smaller Waders}

The lover of bird-life cannot but be struck with the great number of small birds that trip over the mud flats and marshes of the northern Queensland rivers, and, so far as I gather, though I was not in the south at the best season for observing them, of those in the other colonies as well. Indeed, in the colder districts of the latter they are even more numerous.

The Plovers and Dottrels, of which there are nearly a score, resemble, with few exceptions, their European namesakes, and range in size from the little Ring Dottrel 
(Aegialites) to the Great Stone Plover (Oedicnemus), a nocturnal berry-eater of the plains.

The Red-Kneed Dottrel (Erythrogenys) is a summer visitant only to New South Wales; and the Wattled Plover (Lobivanellus), or "Spur Wing," spoils many a day's kangaroo stalking by its provoking habit of rising just in front of one and putting every living thing on the alert by its piercing cries-for which peculiarity colonials have dubbed it the "Alarm Bird." On such occasions, too, I have heard several other epithets, doubtless of local significance only and not worth repeating here, applied to it.

All these birds lay their eggs in a rough-and-ready nest in the sand, the female resorting, when her object is to lure the intruder away, to all the old ruses, feigning a broken wing among others, practised by her kind at home.

The Ibises are of several kinds, and I have seen flocks of the white (Threskiornis) and straw-coloured (Carphibis) species as near Sydney as the National Park.

I also came upon some much larger birds of this family on the beach of Moreton Bay, near a little hamlet appropriately known as Humpy Bong, or "The City of the Dead." I do not know, however, to what species they belonged.

So much for these smailer Grallatores ; for so similar are the rest-the Pratincoles (Glareola), Stilts (Himantopus), Avocet (Recurvirostra), Godwits (Limosa), Sandpipers, Knot (Tringa), Turnstone (Strepsilas), Snipe, and Whimbrels - to those of Europe, that it would be waste of space to treat further of them. 


\section{The Struthious Birds}

The larger members of the order include some of the most characteristic and interesting of Australian birds.

Of these, perhaps the most important, figuring as it does on postage stamps and wine flagons, is the Emu (Dromaius novce-hollandice), a relative of the 0strich of South Africa and the Rhea of the American continent. By no means so shy as most creatures of its dimensions, its extinction can only be a matter of time; for these birds with the rounded breast-bone are an earth-hugging race, but ill-fitted to hold their own in life's battle now that their home is invaded by man and his horses. From Tasmania, they have practically disappeared; nor will their swift strides avail many years longer against the trained horse or well-sighted rifle. Besides being looked upon as a legitimate object of sport, the bird is largely " dispersed" by farmers, who allege that it steals their grass and tears their fences. I find in a back number of the Sydney Morning Herald that, in the year 1888, upwards of ten thousand emus were destroyed in one district alone, while in the same period fifteen hundred of their eggs were broken on one estate.

In fact, Nature's balance seems to have got all topsyturvey, for we find ${ }^{1}$ the New South Wales Government spending in 1891 the extraordinary sum of $£ 50,000$ in bonuses for the destruction of 871 emus, over one million of marsupials, 65,000 hares and rabbits, 11,530 dingoes, 3,502 eagle-hawks, and some other marauders.

And as Australians lend no very enthusiastic support to zoological gardens in their own country, we shall yet have them visiting Regent's Park or Tring to see what sort of a bird is this emu about which their fathers talked so much.

${ }^{1}$ Coghlan: Wealth and Progress of New South Wales. 


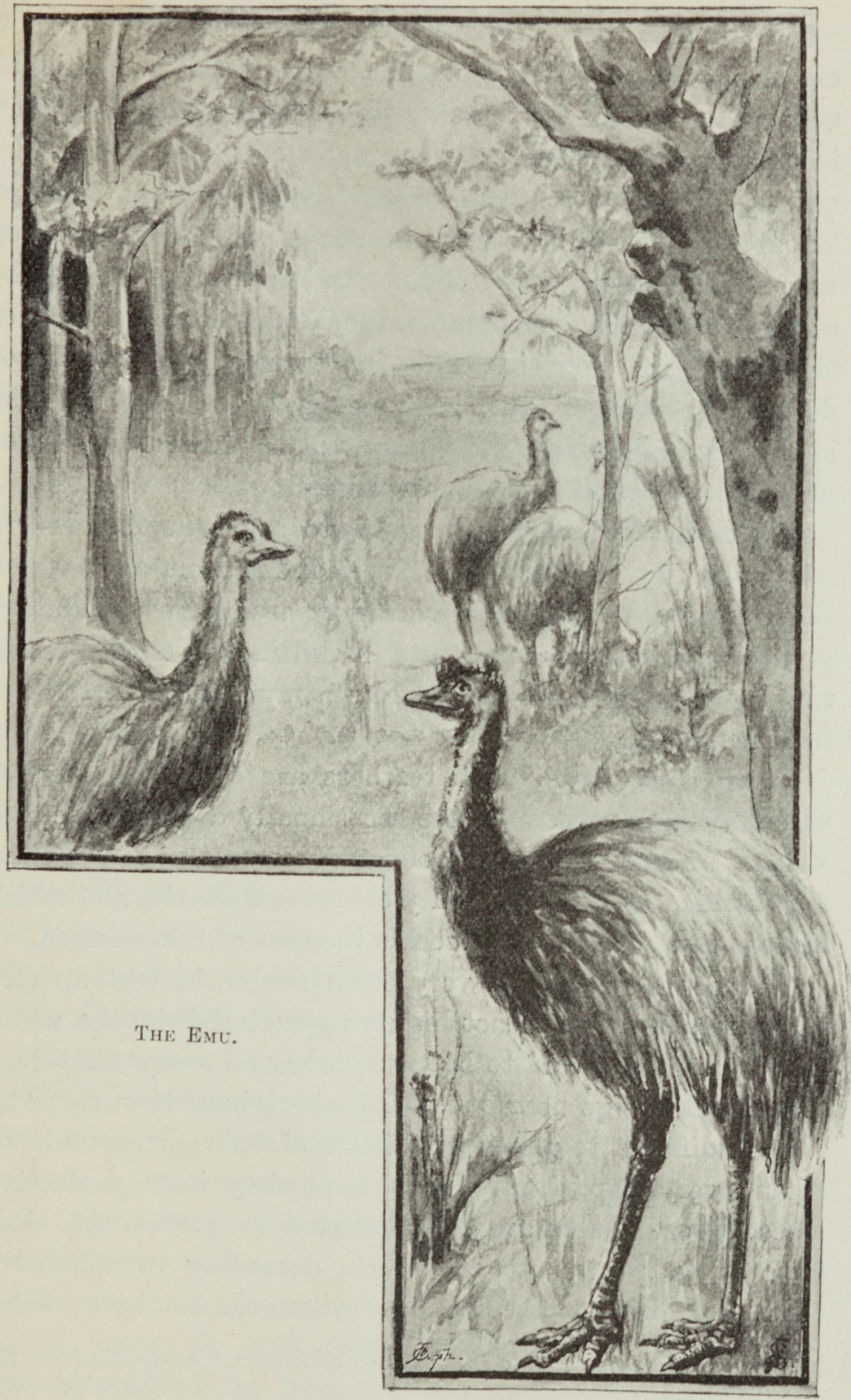


The Emu is practically confined to the southern and eastern portions of the continent. From its prototype, the ostrich, it differs in lacking the beautiful tail-feathers, in the possession of three toes instead of two, and in the curious hair-like covering that serves it as plumage. Though a powerful runner, the wings are of little or no use, which makes it difficult to understand why the aborigines should at once break them, when captured, rather than the legs. Perhaps, like the swan, it is capable of doing some damage with them, though, in common with the cassowary and ostrich, the only mode of defence I ever heard of was with the powerful feet.

The male bird, which may grow to a height of over six feet, takes its share of the duties of incubation, after which it apparently develops other ideas of parental responsibility, giving way to a depraved taste for killing the chicks, which the mother, in consequence, hides away until able to shift for themselves.

The fibrous, dusty black feathers are of no commercial value, although the skins are occasionally exposed in curioshops. Indeed, its only product of any value is the clear oil, of which a large skin will yield several quarts, and which has some reputation as a specific in cases of rheumatism.

Though the bird is a very clean feeder, in fact strictly vegetarian, its flesh is not highly appreciated by the white men ; indeed, it is said to have so strong an aroma that dogs often refuse to go near one. The aborigines, however, who are not difficult to please in matters of this sort, partake of it on every opportunity, though, possibly as a protective measure, the youths are not permitted to eat of this dish until initiated, a process which, according to Mitchell, ${ }^{1}$ consists in being rubbed all over with emu fat by an elder

1 Three Expeditions into the Interior of Eastern A ustralia (vol. ii., p. 346). 
of the tribe. Similarly, the flesh of the eel is tabooed for the youths of most tribes, though protection can hardly be the object of this regulation.

The emu utters a peculiar, low, vibrating note, produced in the female by the operation of an air-bag associated with the windpipe. It has been compared with the "booming" of the bittern. The dark-green eggs are laid in a shallow depression in the earth, sometimes lined with a few stalks of grass or scraps of fern. According to Bennett, the number of a sitting is invariably odd; but this has been questioned, and is, I am afraid, incorrect. These rough-shelled, green eggs are familiar objects enough in the windows of natural history dealers; and in Australian curio-shops they are sold as candle-shades, the ends being removed and the central portion engraved with representations of Australian animals and scenery.

The Spotted Emu (D. irroratus) is a distinct species representing its absent congener in the north-western and western parts of the continent; and it seems probable that the two species meet somewhere among the plains of South Australia.

The Black Emu, an expression borrowed from the aboriginals of northern Queensland, is the Cassowary, which we must now consider.

The Cassowary (Casuarius austratis) of Australia is a member of a family whose headquarters are in the Bismarck Archipelago. Of this rara avis, which is met with sparingly in northern Queensland, there seems a great deal yet to learn, and indeed naturalists have not much time, for it has been ruthlessly slaughtered for its beautiful skin.

Like the emu, it seems to feed largely, if not entirely, on the native fig and peach and other soft fruits; and near the roots of the trees that supply it with this diet, it 
deposits on the ground its five eggs of pale green. One of these $^{1}$ is paler and smoother than the rest. The stature of the cassowary, rather under five feet, is somewhat below that of the emu, like which it has bright eyes and hairy plumage. The distinguishing characters, however, are the blue head, black helmet, and red wattles on the neck. It is, like the emu, an excellent swimmer on occasion. The bird ( $C$. bennettii), described at some length by Bennett, is the Mooruk, an allied bird of New Britain, and there are other species in Ceram and New Guinea.

Mr. Ramsay, ${ }^{2}$ in the course of an interesting account of this beautiful bird, says :-

"Towards evening and early morning, they usually visit their favourite feeding trees, such as the native figs, Leichaidt-tree ( $S$. leichardti), and various species of Acmona, Jambosa, Davidsonia, \&c.; they appear to be particularly fond of the astringent fruit of the Leichardttree and of a species of Maranta.... They ascertain the flavour of their diet by first taking it up in the tip of their bill and giving it a slight pinch; and if not suitable, they throw it aside. . . . . The birds are very powerful, and dangerous to approach when wounded. On more than one occasion a wounded bird has caused a naturalist to take to a tree; the sharp nail of the inner toe is a most dangerous weapon, quite equal to the claw of a large kangaroo, and capable of doing quite as much execution. ... I found the Cassowaries to be excellent swimmers. . . . A young bird . . . during my visit succeeded in jumping out of its yard over a fence more than six feet high."

Of the Bustards, ${ }^{3}$ so plentifully represented in Africa,

1 Proceedings of the Zoological Society, 1876.

2 Ditto (xliv., p. 120).

3 The so-called "Bustard" (Bernicla) of America is a goose. 
the more southern continent has but a single species (Choriotis), and even that is disappearing so rapidly before the progress of civilisation, that colonial landscape may soon miss it altogether, as have most of our own plains for the past sixty years.

This Australian Bustard, popularly known as the Wild Turkey, a name open to criticism, is excellent eating, and has not in this respect its equal in the bush. In the salad days of the race, the blacks used to secure it by clubbing, creeping up to it under cover of a leafy screen. Nowadays, however, colonials find it exceedingly timorous and suspicious, above all of any one on foot, so that it is commonly stalked on horseback or in a buggy driven in circles, and shot as soon as it rises on the wing.

The bird seems to lay one egg (or at most two) on the ground. It lives entirely in the plains, feeding on lizards and roots. The general plumage is black with white and grey markings. In the mouth is a curious modification of the bellows-like arrangement found beneath the tongue of the Great Bustard of Europe, and associated by country folks with the function of conveying water to its young.

With two highly characteristic Australian birds, the Jabiru and Native Companion, we conclude this order.

The Jabiru (Xenorhynchus), a drawing of which forms the frontispiece to Bennett's interesting work, ${ }^{1}$ is a rare bird nowadays. Formerly, I was given to understand, it was a common object on the shores of the lagoons near Rockhampton, where I recently looked for it in vain. In fact, this stately fisher is gradually retreating, with a good many companions, from the path of the alldestroyer.

The jabiru bears some resemblance to the Indian 1 Gatherings of a Naturalist. 
Adjutant, though the powerful bill of the latter is not curved upward at the tip as in the Australian bird.

The Native Companion (Grus australasianus) is one of the most remarkable of all the cranes, and is, as its name implies, a sociable bird, not averse to the company of man himself. About the farms, it lives in a semi-domesticated state, as no one persecutes it, even the natives having no penchant for the flesh of the "Caraduck" ; so that it is blest above most birds, few of which respond more readily to kindness - though I have read somewhere that it has an awkward habit of sticking its long bill into children's eyes when at play with them. It is a fine bird, standing when full grown over four feet high, and weighing as much as 20 pounds. The plumage is grey, the top of the head green. The male, the larger bird of the two, has a long pouch hanging from the throat. It seems to feed on small reptiles; and there was a large crane closely resembling this species in the garden of an hotel at which I stayed at Buitenzorg (Java), which would stalk gravely up the steps into the verandah where we were taking coffee, and catch pieces of bread in its long bill with great dexterity. Occasionally, too, it would snap up one of the little fly-eating geckoes that covered the walls and ceilings as soon as the lamps were lit. The long white eggs, covered with spots and blotches of reddish brown, are two in number, and are deposited on the bare earth. Two were laid and incubated this year at Regent's Park.

The greatest peculiarity of this bird, which occurs, by the way, all over Australia (but not in Tasmania), is its weakness for dancing, a proclivity which it shares with a few other feathered Australians.

I was on one occasion so fortunate as to witness a performance of this description through a telescope from 


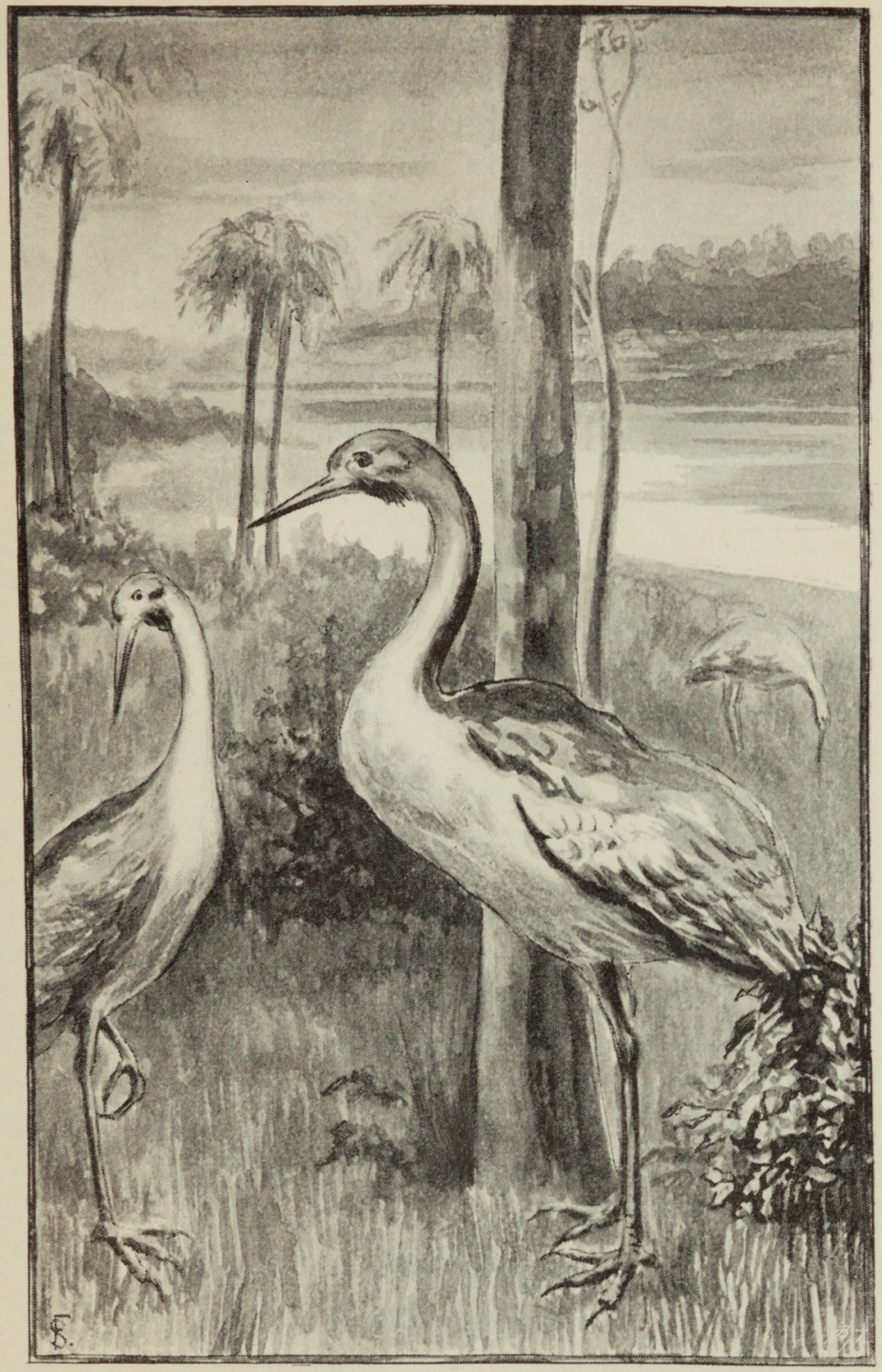

Native Companion. 
the upper deck of a steamer anchored in a Queensland river. Five of these birds were curveting round each other in the swamps with ludicrous gravity. Unfortunately, something soon disturbed them and they suddenly rose to a great height in the air, wheeling in broadening circles and uttering loud cries. They pitched again in another part of the marshes, but the quadrille was not re-opened, and I never saw any more of these birds.

Other quarters of the globe are not without their dancing birds, of which mention may be made of the African Saddle-bill (Ephippiorhynchus), and the ypicaita and jacanas of South America. 


\section{PART III.-PERCHING BIRDS}

\section{THE PERCHERS}

There are a number of birds that are sure to strike the visitor as soon as he has got away from the waterside and had a ramble or two in the interior. The wealth of Australian bird-life is confusing; but only the more typical forms are given in the present handbook. Gould's magnificent folio works, which may be consulted in home and colonial national libraries, contain plates and descriptions of every species then described, and but few have been added since he wrote.

The Perchers (Insessores) comprise most of the characteristic birds not already given, the gaudy parrots, the remarkable lyre birds and bower-builders, the graceful little honey eaters and the large group of kingfishers. I proceed to give a brief sketch of fifteen of the principal families.

\section{The King fishers}

More than half the Kingfishers known to science occur nowhere out of the Australian region; and among its wonders are kingfishers that love not the water and never, save perhaps in captivity, touch fish of any kind. 
As a matter of fact, the true fishing species are but few in number, and include a bird (Alcyone azurea) identical to all intents and purposes with our own, a larger kind in Tasmania, and two others (A. pulchra and A. pusilla) found only in Queensland.

The bulk, however, and those of chief interest to the visitor, live far from the waterside and feed on reptiles and frogs.

The largest and most familiar of these is the celebrated Laughing Jackass (Dacelogigas), called erroneously by one writer a "Butcher Bird." It is about the size of our common crow, of a dull-brown colour, with dashes of pale blue on the wing-covers, and has an enormously powerful bill. Why "Jackass" I know not, as its profile does not particularly resemble that of the patient donkey, nor can its voice be very aptly compared with either braying or laughing. Barton ${ }^{1}$ suggests that the word is of French origin, from a verb signifying to giggle.

From its habit of starting its discordant pæan somewhere near sunrise and, after keeping comparatively quiet all through the hotter hours, cackling a 'requiem to the day's decline,' the bird has been called the Settler's Clock. It may be remarked, however, that this by no means takes place with the methodical precision that romancers write of in their letters home.

The Kookaburra, as the aboriginals call it in some parts, is differently treated in different districts. From its weakness, real or supposed, for snakes as an article of food, it is considered by some of the governments worth protecting.

In some parts, even where not under this patronage, it is treated as almost sacred; but in one place I stayed at the noisy cacklers were shot without mercy.

1 Australian Physiography (p. 132). 
The bird is commonly supposed to laugh at anyone in trouble; but I recollect on one occasion being abruptly deserted by my horse in presence of several of them without so much as an audible smile reaching me from the boughs

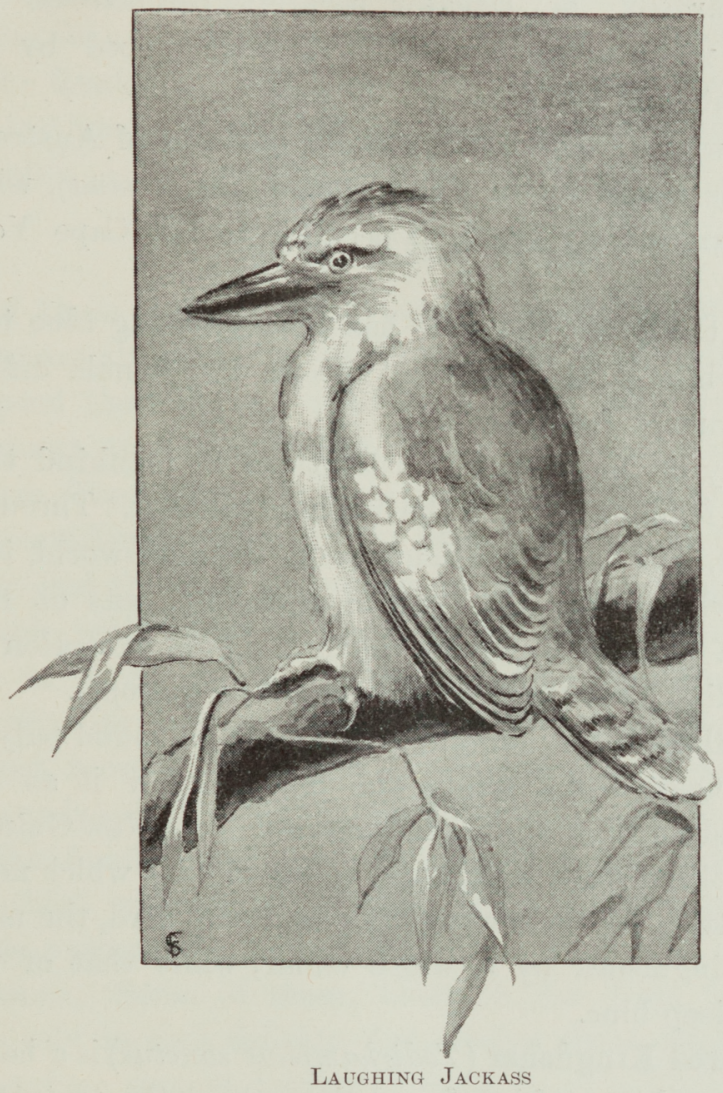

overhead. My horse had been frightened by a small green snake lying in the roadway; but as I had to make up to the animal, which was the property of a friend, I was unable to watch, as I could have wished, whether the 
reputed snake-killers availed themselves of the opportunity.

Like the native companion, forbearance has made a fearless bird of it; and it roosts freely in the various botanic gardens, or remains sedately perched on the telegraph wires along the railroad, undisturbed by the leisurely rattle of the passing "express."

In the western and north-western portions of Australia its place is taken by an allied species (D. cervina), while another, named after Leach, is peculiar to the Cape York district.

In both the latter, the male has distinguishing blue tailfeathers, while in the common species the female differs little in plumage from her lord.

It is only in the artificial institutions of mankind that we find the female assuming the brighter raiment. Throughout nature, and more particularly in the bird-world, it is the male who, during the time of courtship, puts on fine feathers, a rule to which we have a single exception in an Australian Tree Creeper (Climacteres erythrops).

The Yellow-billed Kingfisher (Syma) is found only in northern Queensland, where the blacks know it as the Poditti, and an allied species is described from New Guinea.

The northern Bush Kingfisher (Cyanalcyon), which nests in hollow trees far from water, is a beautiful bird, the male being distinguished by a white collar, while that of the female is deep blue.

The Sacred Kingfisher (Todirhamphus sanctus) is a handsome blue and green bird found throughout the continent, but not in Tasmania. Wherefore, one writer deliberately calls it the Van Diemen's Land Jackass! It breeds just before Christmas in New South Wales, flying northward in the new year and returning at the latter end of August. The young are less brilliant than their assiduous parents, 
who are for ever feeding them with insects, although their own food consists of land-crabs and small reptiles.

The Red-backed and Sordid kingfishers are allied species, the last occurring only in Queensland; and lastly, the White-tailed Kingfisher (Tanysiptera sylvia) is found only in the Cape York Peninsula, the natives of which know it as the Quatawur. This beautiful bird, with the long blue tail-feathers and red bill and feet, lays its white eggs in ant-hills.

\section{The Honey Eaters}

Of these elegant and typically Australian Meliphagida there are altogether some fifty species, nearly all of which suspend their dainty little nests, lined with wallaby fur, blossoms, and soft grasses, among the banksias and mangroves. These exquisite little fragments of bird architecture are considered useful by the bronze cuckoo, and you may often find the dark green egg of the vagrant reposing side by side with those of the rightful owner; which tempts you to throw it out ere the warlike chick comes forth to terrorise its foster-parents and murder their offspring. It is best, however, to refrain, for nature is working out her own ends-darkly, maybe, yet not without unerring wisdom.

The family name has reference to the singular method by which, with the aid of their brush-tipped tongues, these birds extract the honey and pollen from the eucalyptus blossom. Some of them, however, far from feeding exclusively on such delicate diet, derive their chief nourishment from insects, berries or seeds.

It is out of the question to give any systematic account of so large a family, and a dozen typical species will answer every purpose. They are widely distributed in the Colonies, being worst represented in Western Australia and Tasmania, the former colony having less than twenty species, the 
latter under a dozen. Their presence in numbe-s is an unwelcome sign to the prospector, as they particularly affect the banksia and like plants that thrive best in the poorest and most arid of soils.

The antics which some of them perform, their acrobatic turns and somersaults in the air, have fascinated me by the hour. I have seen nothing to rival them in the birdworld.

One of the most remarkable groups of honey-eaters is that of the Wattle Birds, to which, if I am not mistaken, belongs the "Gill Bird" dear to Sydney pot-hunters.

The Wattle Bird (Anthochera carunculata) is a native of every colony except Tasmania. That island has, however, a Wattle Bird (A.inauris) of its own which is largely eaten at Hobart, and which, like the allied "Cherry-Picker" and Black-headed Honey Eater, is not found on the mainland. I tasted the bird there in August and, cooked, if I remember rightly, with the trail, it was excellent and fat as quail. A third Wattle Bird (Anellobia lunulata) is confined to Western Australia.

The most tuneful members of the family are, however, the Singing Honey Eater (Ptilotis sonora), a pugnacious little bird with a weakness for big seeds, and the Brown Honey Eater (Stigmatops) of New South Wales, which, though a sweet songster, is the least attractive of all in appearance. Allied to the first of these is a Yellow-tufted bird ( $P$. auricomis), the most exquisite of all, which lays its two little pink eggs splashed with lilac in a large nest carefully hidden away amongst the luxuriant fern beds or up in the dense casuarina scrub. In its proper home, Queensland and Now South Wales, beyond the limits of which it rarely strays, it assembles in February in dense flocks ${ }^{1}$ to fight noisily over the fallen pears and oranges, 
of which it is desperately fond. In the whole directory of birds, it would be impossible to find a more quarrelsome and pugnacious family than these honey-eaters.

A familiar sound enough among the banksias is the harsh note of the Common Honey Eater (Meliornis novahollandice), which, distinguished by the white feathers on its head and wings, is met with throughout the southern colonies.

The handsome Mock Regent Bird (Meliphaga phrygia) also known from some white excrescences on the face as the Warty-faced Honey Eater, has the most beautiful glossy black and yellow plumage; and if it is one of the most attractive of its kind, it is also beyond all competition the most pugnacious bird in Australia, its love of fighting embracing even others of its own species.

I used to watch by the hour a pair that belonged to a Brisbane lady, which had four or five meals of seeds and "ants' eggs" daily, and filled up their spare time in endeavouring to blind each other, but they both fenced too skilfully for anything to go amiss.

There are five Friar Birds, or Leatherheads, which feed but little on honey.

Of these, the Poor Soldier (Tropidorhynchus corniculatus) occurs only in New South Wales and Queensland, and $T$. buceroides only in the latter colony; besides which, there are the Yellow-throat of the south-east and the Silver-crowned bird of the north-west district.

The Blue Eye (Entomyza cyanotis), which one often shoots near Sydney, especially down Illawarra way, is a large species of honey-eater, which lays its two spotted pink eggs in the deserted nest of the Pomatorhinus. Varying its diet, like most of its race, it may be seen at one moment clinging butterfly-like to the blossom and extracting nectar, anon chasing the winged insects like any flycatcher. 
The Spine Bill (Acanthorhynchus tenuirostris) of New South Wales and Tasmania is a very pretty little bird, though a much feebler songster than its West Australian congener, A. superciliosus.

The Garrulous Honey Eater (Myzantha garrula), or Miner, of Tasmania is a restless, noisy bird, represented in Western Australia by the allied $M$. obscura, and in the north-west by the far handsomer $M$. lutea. Their food consists chiefly of insects and berries.

The Bell Bird ${ }^{1}$ (Manorhina melanorhys), or Dilbong, is found only in the scrub of New South Wales, where its bell-like note often breaks the silence with startling suddenness. Its voice is welcome to the thirsty traveller, as it generally frequents the neighbourhood of water in some form or other. Being one of the most inquisitive of birds, it is not difficult to lure within gunshot, and I believe it is excellent eating.

The Swallow Dicœum (D. hirundinaceum) is not unlike our wren, and is fairly common among the wattles, where it hops about after insects or berries, or, perched over its cup-like nest, trills a feeble lay.

The Sun Bird (Nectarinia australis), most of whose relatives are far away in South Africa, seeks its insect food among the wild flowers on Albany Island, where its shrill note is heard from the midst of some low bush among the mangroves. There too it hangs its elegant, hooded nest, gaily decked with seaweeds and lined within with moss and feathers.

${ }^{1}$ Quite distinct from the bird (Oreöca cristata) bearing the same name in Western Australia or (Arapunga alba) in America. 


\section{The Parrot Family}

A flock of bright red and green parrakeets, startled by the passing train, were among the first indications to me that I was in a new part of the Old World. The day has gone by, it is true, when, as Gould ${ }^{1}$ saw them, birds now rare would chase each other up and down the streets of Hobart and Adelaide. Yet a great variety of parrots may still be seen a little way out among the plantations. But although the beautiful plumage and merry, if somewhat discordant, chattering combine to relieve the monotony of the bush, these birds, made so much of when brought to Europe, are not the recipients of much kindness in their own home. In fact, they are the reverse of popular there. The farmer, mindful of his ripening grain, awaits them with his heaviest charge of shot. The homesick golddigger, sighing for one note from the lark or nightingale, yearns for an opportunity of twisting the gaudy screamers' necks, and is not slow to avail himself of it, should such arise. The aboriginal, appreciating them most, as he does all else, in a half-cooked state, thins their ranks sadly with his spear and boomerang.

It is incorrect to speak of this family as purely tropical, for parrots are plentiful in Tasmania, and one American species is peculiar to North Carolina, which is almost as far north of the equator.

The colonists make little distinction between the parrots, parrakeets and cockatoos, which is not surprising, seeing that this is a matter on which naturalists are by no means agreed.

Their beautiful plumage, and still more their powers of mimicry, make these birds great cage favourites all the world over; and a clever talking parrot, especially one of

1 The Birds of Australia. 
the red-tailed African grey birds, always commands a good price. Like anything else good, the value of such a parrot is pretty generally known nowadays, and it is no longer easy, even in the bush, to drive much of a bargain. The cheapest bird I ever came across was an exceedingly clever Sulphur-crested Cockatoo (Cacatuce galerita), which our ship's doctor purchased at Brisbane for a sovereign. The poor bird's frantic gesticulations when, at Batavia and Colombo, large hawks and kites hovered above its perch, the head thrown violently forward and the pale yellow crest spread like a fan, were extremely amusing. Humboldt mentions a remarkable case in which a South American parrot had preserved some words of a dead language, the tribe to which its owner belonged having been recently exterminated.

In the state of nature, these birds exhibit great variety in size, colouring, and habits. They feed for the most part on grain, levied from the farmer, and on grubs, which with the aid of their powerful hooked bills they dig out of the soft bark of the gum trees, which may be seen scored in all directions. They are able to go for long periods without drinking, though several kinds, the Grass Parrakeets more particularly, revel in the dew that falls very heavily in those latitudes. Still, they undoubtedly require water when caged, both for drinking purposes and an occasional bath, and it is the greatest cruelty to keep them without it, just as it is to split their tongues to make them talk better !

Their tastes, too, often undergo strange changes in captivity ; and Greene ${ }^{1}$ quotes some amusing instances in which, like the now carnivorous Kea of New Zealand, they have become fond of meat, though taking only grain on first arriving at the docks.

\section{Parrots in Captivity.}


They build practically no nest, laying their white eggs, the cockatoos two only, but some of the smaller birds as many as ten, in hollow tree spouts or in some niche in the rocks.

It now seems desirable, after these few introductory remarks, to take a general view of the family, which is perhaps the most important and typical of Australian birds.

Any one whose courage bids him brave the uproar of the Parrot House at Regent's Park will see that Australia has contributed a large proportion of the chatterers, the rare black cockatoos, and the exquisite little lories.

The grain-feeders more especially grow to their full size but slowly; and careful observation of these birds in captivity has gone far to confirm what was already inferred that, in conformity to a law of nature's framing, these creatures of gradual growth are exceedingly long-lived.

\section{The Cockatoos}

Of the fifteen cockatoos, half, in round numbers, are black, the other half white. The cockatoos are well represented in the Philippines.

The Sulphur Crest (Cacatua galerita), already referred to, is one of the least costly and most fascinating. The old birds, well trained, are most amusing pets, the young ones just shot and well cooked are first-rate eating.

The allied $C$. leadbeteri, an excitable and incurable screamer, is distinguished by its delicate rose-tint and crimson crest; and the northern $C$. sanguinea by a number of blood-red stains. The other white cockatoos are the hardy Rose-breasted bird of the interior and two more in the southern colonies, one confined to the east, the other to the west. 
Coming to the so-called Black Cockatoos, which are mostly dark metallic green, we have the Black Cockatoo (Calaptorhynchus) of the north, the allied Red-tailed species of the Swan River district, the Banksian Cockatoo that with its powerful bill scores every tree for miles around, and $C$. leachii, distinguished by a tuft of yellow feathers on the head. The last-named is the least of the family, the largest being $C$. funereus, which has a singular habit of snipping small branches off the trees, apparently out of pure mischief.

The list of cockatoos is complete with four more birds. The Yellow-eared bird ( $C$. xanthonotis) is a native of Tasmania, where it is regarded as the messenger of coming rain. Baudin's Cockatoo, a West Australian species with conspicuous white tail-feathers; the more common redheaded Gang-Gang (Callocephalon) of Tasmania and New South Wales, which the Zoological Gardens seem to have lost more frequently than any other cockatoo; and a Cape York Black Cockatoo (Microglossum), a confirmed pruner of trees, are the rest.

\section{Parrots, Parrakeets, etc.}

Though some groups of these birds are by no means so well represented as in the Moluccas and New World generally, Australia has them nevertheless in great variety.

Of the beautiful Lories there are three, including the red-headed King Lory (referred by some authorities to the Platycerci or Parrakeets) with scarlet breast, green back and blue tail, truly a blaze of colour, and also two crimsonwinged species of Ptistes.

When flying, the Parrakeets (Platycerci) present by reason of their broad spread of tail-feathers a somewhat singular appearance. 
Out of a large number of species, mention can be made only of the most familiar; to wit, the "Twenty-Eight" (P. semitorquatus) of Western Australia, so called from a supposed resemblance between the sound of those words and its oft-reiterated cry; the yellow-bellied Green Parrot of Tasmania, where it is in some request for the table; the Smutty Parrot ( $P$. venustus) of the north coast; the hardy little Rosella (P.eximius) of New South Wales and Tasmania, and the allied Rosellas (or Rose-hills) of Queensland ( $P$. palliceps, a duller coloured, though tropical, type) and Western Australia (P. icterotis). There are, further, the western Blue Parrot, which lays its eight or nine white eggs in some hollow mahogany tree, and the Crested Parrakeet (Nymphicus) which, according to Bennett, 1 suddenly reappeared in New South Wales during a drought and after an absence of more than thirty years.

The Grass Parrakeets (Euphema) feed, like the last group, mostly on the ground; and I have more than once flushed them when stalking, little appreciating their beauty on such occasions, as their shrieking is fatal. Grey mentions that his party was indebted to some members of the cockatoo group for warning them of any movement on the part of the blacks. This one can easily appreciate, only the service would cut both ways.

The most familiar, and almost the only one in evidence at the stores of London dealers, is the favourite little warbling Bujerigar (Melopsittacus undulatus), or, as it is variously called, the "Zebra Parrakeet," "Canary Parrot," " Shell Parrot," \&c.

This winsome little bird is still fairly plentiful not far out of Adelaide, though the raids of the birdcatchers must be enormous, since I could, at the time of writing, lay my hand on fifty dozen for sale in England alone. I have

1 Gatherings of a Naturalist (p. 168). 
frequently seen this parrot in private houses in Germany; indeed, the inhabitants of that country are even greater parrot-fanciers than ourselves, and unquestionably treat birds in general with much more kindness than sny other Continental nation, if not even better than some islanders! The Bujerigar, too well known to need description, is in great demand for its lively anties and ceaseless chattering; but, for its size, the popular one certainly bites on occasion with wonderful vigour, as I once had reason to know.

The other members of the same group, half a dozen in number, are the so-called Ground Parrot (Euphema elegans) and E. splendida of Western Australia; the allied E. chrysostoma and E. aurantia, summer visitors in Tasmania ; E. pulchella, of New South Wales, and a pale pink parrakeet named after Bourke.

In a few words, too, I must dismiss the remaining group of this popular family, the honey-eating Lorrikeets, which have the remarkable brush-tipped tongue of all honeyeating birds, and are, further, most unpleasantly distinguished by a fœtid, musky smell. They extract their favourite food from the banksia and mimosa blossoms, and lay their white eggs in hollow trees.

Among them are the scarlet-throated, red-tailed, green Swift (Lathamus) of Tasmania, three species of Trichoglossus - the Red-collared species of Queensland and the Blue-bellied and Scaly-breasted (in allusion to the yellow breast feathers) Lorikeets of New South Wales-and, lastly, the Varied Lorikeet (Ptilosclera) and the Musky Lorikeet.

\section{The Nightjars, or Moreporks}

The Nightjar, misnamed, from an absurd superstition, "Goatsucker," is a familiar bird of twilight on our own countryside, where we can often watch it in the half light, 
winging its silent flight among the ghostly oaks in pursuit of the fat white moths it loves so well. Australia, where is no gloaming, has yet its Caprimulgida, and there they go by the name of Morepork, as the birds are said to utter these words. In point of fact, there is about as much resemblance as is to be found in the prattlings of human yearlings to such words of her Majesty's English as their fond mothers shall choose to assign to them; and if any bird utters the words "more pork" it is the Boobook owl. ${ }^{1}$

Most of the Australian nightjars are of the genus Podargus, the members of which, unlike the rest of the family, construct a rough nest. The others lay their eggs (which are white, excepting those of the Spotted Nightjar) in some hollow tree or on the bare earth.

Darkness falls swiftly in those southern lands, and with none of the twilight which has such romantic associations in the Northern hemisphere. So the Moreporks sleep all day and come forth when the light fails. Some rest in hollow trees, and are easily disturbed by tapping on the outer bark, when they at once peep out of the opening. But, if collecting is the object, they withdraw as a rule too promptly for any chance of a shot, and it is best to continue the tapping until they at length fly to a neighbouring shelter, when they are easily dropped. Others that squat all day on the ground are so coloured as to closely resemble their gite, so closely indeed that folks have been known to tread upon them. Though awkward enough when perched among the branches or at rest on the ground, their movements in the air, especially those of the strong-winged Eurostopodus, are exceedingly rapid.

1 The so-called "Morepork" of New Zealand is a small owl. 


\section{The Swifts and Swallows}

One swallow does not make a summer even with us, and in Queensland, at all events, still less so, for one species seems to be there (the Black and White bird) at all times. What the new arrival will at once remark, however, is that the little Hirundo frontalis that flits about the arcades and verandahs of Sydney and Melbourne is dumb, and utters not the familiar tweet tweet of our own bird.

Of Swifts there are two, the Spine-tailed (Chatura caudacuta) and Cypsetus pacificus. The first of these flies at a great altitude, and is so powerful on the wing that, according to Gould, it could traverse Bass' Strait, a hundred miles, in the course of an hour. This makes it the more remarkable that it should never visit New Zealand. It appears in New South Wales about Christmas time, rather earlier if anything, and leaves early in April. One was shot in England some fifty years ago.

Of Swallows there are five. Gould distinguishes the Torres Strait bird from Hirundo frontalis, but although I have seen numbers, presumably of the former, off Cape York, I never thought of procuring one; for I must confess to a preference for studying birds alive, and lack that useful collecting instinct which prompts gentlemen to shoot hundreds of small birds in outlying districts on the offchance of securing a new species on which to bestow their often unmusical names-though I fully recognise the great usefulness of these persons to science.

There is no sand-martin in Australia, but the most eccentric architects of the family are the white-breasted Cheramceca of Western Australia, which deposits its nine white eggs in the deserted hole of a rat, and the elegant little Fairy Martins (Lagenoplastes ariel), which construct 
a remarkable mud nest in shape not unlike a retort. These sociable little birds with the red head, brown wings and white belly, lay four streaky white eggs.

\section{The Wood Swallows}

I do not place these curious Artamida next the swallows to suggest any relationship, for the fact is they have nothing whatever in common save the worthless analogy of popular names.

They are not migratory these Wood Swallows or Swallow-Shrikes, as they are sometimes called, remaining in Australia throughout the year. Gregarious they are, however, above most birds, for they swarm like bees, hanging in dense masses from the mangroves.

There are several kinds, the chief being the Grey Wood Swallow (Artamus cinereus) of Western Australia, which feeds largely on the seeds of the grass tree (Xavthorhaca), and the commoner Artamus sordidus, A. personatus, and the Queensland White-rumped (A. leucopygiatis) bird.

Though there is some little difference of opinion as to the proper position of this remarkable family, which are strongly represented in New Guinea and the Malay Archipelago, their nearest relatives are perhaps the Starlings.

\section{The Lyre Birds}

Allied to the tiny wrens are these beautiful and emblematic Australian birds, distinguished by an extraordinary development of tail, some suggestion of which is found in the Black Grouse, the Indian Dicrurus, and the lyre-tailed Nightjar of America.

Before the newly-arrived visitor can get a chance of seeing the beautiful Menura in its native haunts, he grows only too 
familiar with the tails in the windows of Sydney shops, as indeed in curio-stores in London. These ornamental crests, the badge of the male bird, are a couple of feet in length,

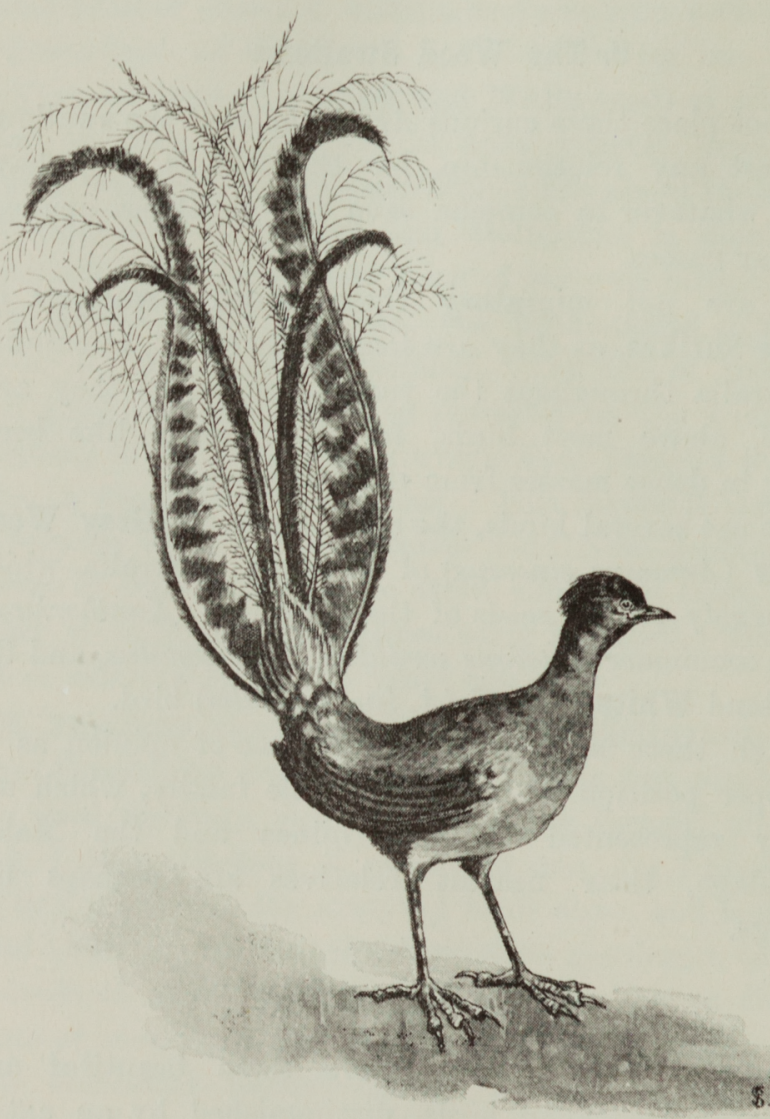

LYRE BIRD.

the outer feathers curved like the instrument of Phœbus and marked with parallel bars, the inner feathers of a silver-grey, and very fragile.

The bird, which has its chief home in New South Wales, 
is now protected by law, and not a moment too soon, or there might ere long have been more of the tails in Sydney than in the rest of the colony. Not long since, for example, two enterprising brothers employed a number of men to shoot the luckless male birds, in which, after some practice, they were unfortunately so successful, that five hundred dozen of the beautiful tails were reported to have reached Sydney in the course of a few weeks. It is not difficult to understand how, at this rate, the price of the tails which, according to Bennett, was as high as thirty shillings the pair fifty years ago, should have fallen to one-third the price, at which figure I could have bought a hundred pairs in Sydney, had I been so minded.

So that the poor Lyre-Bird, laying but one egg each breeding season, which moreover takes as long as four or five weeks to hatch, is indeed doomed to extinction, and is already very scarce in the settled districts.

I only once saw the bird alive, and that was when, riding through the scrub, I suddenly came on one which was running about a clearing among some newly-felled trees; and promptly I wasted two or three camera plates before it had scuttled out of sight. The temptation to "snap" when confronted by singular creatures in distant lands is irresistible. Often enough, especially out near Illawarra, I heard its pleasing note, for like the Indian Jungle Fowl, it is more often heard than seen; but I never got a second glimpse of it.

People residing in the country districts, however, seem still familiar with the "Pheasant," as they sometimes call it, and tell how it dances to an admiring seraglio in a space cleared by itself, perching anon on a fallen trunk and displaying its tail, prouder than any peacock.

The single egg is laid in a domed nest about a foot in height and resting on the ground. 
It is a poor flier and seldom seen on the wing; but it runs quickly over the ground, and is also able, with its powerful legs and feet, to leap into branches several feet above it.

It has a curious habit of digging "corroboree-places" (little pits in the sand), which, some have supposed, may act as traps for spiders and insects.

Besides a mellow note of its own, from which the aboriginals know it as the Bullan-Bullan, ${ }^{1}$ the bird is a capital mimic.

Two species of lyre-bird are generally recognised, Menura superba, of New South Wales and the other southern colonies, and $M$. alberti, confined to the first-named colony, and distinguished from the rest by its reddish plumage and the absence of brown bars from the short, outer tailfeathers.

Gould describes a third species, $M$. victoria, which is now considered only a variety.

A near relative of the lyre-birds is the singular CoachWhip Bird (Psophodes crepitans), so called from its curious sharp note, often heard out at Bulli and throughout New South Wales.

\section{The Bower Builders}

Unrivalled perhaps among the feathered architects of the world stand the Bower Birds. Not that the nest, an inconspicuous structure in the fork of a gum tree, calls for much remark. It were easy to call to mind a hundred nests of far greater merit, such, for instance, as the two-roomed abode of the Oven Bird, the flask-like domicile of the Fairy Martin, the delicate dwellings of the Orioles and Humming Birds, the pensile nests of the Indian Tailor

1 Note the frequent reduplication (Jacky-jacky, Wonga-wonga, Debbil-debbil, \&c.) in their dialects. 
and African Weaver, the wondrous mounds of the Megapodes.

But the Bower Birds are interesting to us as furnishing the only known instance of a bird constructing, besides the nest, a playground or meeting-hall. This takes the form

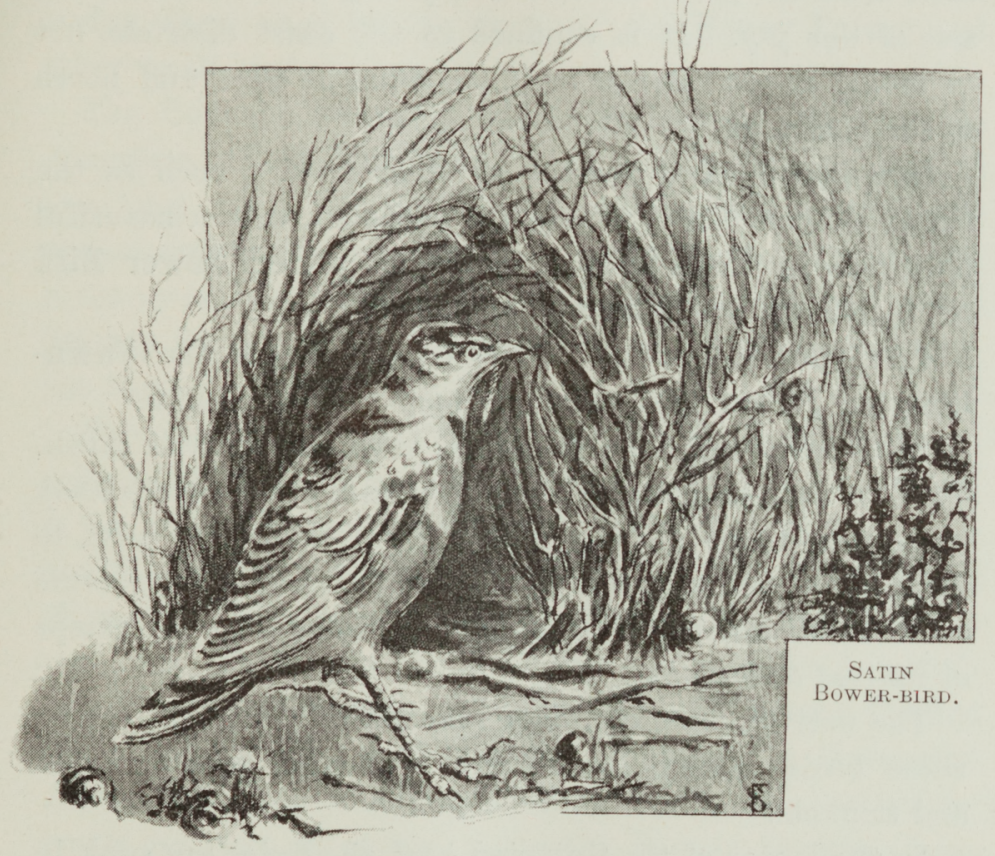

of a most ingenious edifice of twigs stuck in the ground and bent over so as to form an arch.

They decorate this pavilion with shells, bright parrots' feathers, and other ornamental trifles. These bowers are now sufficiently familiar in public collections; and I once came across three in Queensland within a short distance, all of which, however, were apparently deserted, as the feathers on them were bedraggled and there was no sign 
of the birds themselves. All these birds feed chiefly on native figs and berries, also on young corn when they can get it.

The Satin Bower Bird (Ptilorhynchus holosericeus), so called from the beautiful glossy black plumage, only assumed after several moults, that distinguishes the old male from the green females and young birds, is about the size of our jay. It is confined to the coast districts, not occurring in the interior or in the extreme west and north of the continent.

Queensland has a number of other species, such as the Great Bower Bird (Chlamydera nuchalis), with a beautiful pink ruff, in which it resembles the Spotted Bower Bird (C. maculata) and Guttated species.

There are two others, $C$. cerviniventris, or the Fawnbreasted Bower Bird, and Prianodura newtoniana.

The bowers differ considerably, both in size and finish. The last-named bird constructs the least ornate and roomy of all, the twigs not even being bent, as in the rest, to increase the accommodation, nor does it trick its playground out with all manner of coloured rags stolen from the camps of natives or settlers.

The natives, who, curiously enough, refrain from eating these birds, ${ }^{1}$ always search the bowers for missing pipes and trinkets.

In the bower of the Guttated bird, the twigs are sunk in two parallel furrows and interlaced so as to meet over a curved platform of twigs.

The Cat Bird ${ }^{2}$ (Aituradus), so called from its peculiar

1 In connection with the omnivorous instincts of the Australian aboriginals, I have been told that they think eggs as fit food only for women and children, although they seem to make an exception of those of the brush-turkeys and other megapodes.

${ }^{2}$ Quite distinct from the Cat Bird (Turdus felivox) of the United States. 
cry, is related to this group, and another bower builder is known as the Regent Bird (Sericulus), a handsomo black and yellow species.

\section{The Cuckoos}

Much remains to be learnt of the habits of Australian cuckoos, the majority of which are, like our own, parasitic, laying their eggs in the nests of the Honey Eaters and other small birds.

The Coucals, however, which are nearly allied to the American "Cow-Bird," build a large dome-shaped nest in the long grass, having two approaches. For no other reason apparently, one author ${ }^{1}$ would exclude this family (Centropus) from the cuckoos, preferring to call them Swamp Parrots, or, as he describes one, a " tree parrot with the foot of a lark."

The wandering, parasitic cuckoos, which, in the southern colonies at least, are migratory, are of several kinds. There is the great Channel-Bill (Scythrops) of the coast of New South Wales, which utters its weird cry on the approach of rain. There is a Queensland bird (Cuculus) allied to our own. Further, a southern group (Cacomantis) including the Greater Cuckoo (C. pallidus) and Lesser Cuckoo (C. flabelliformis), both summer migrants in Tasmania. And, lastly, the widely-distributed Eudynamis, which deposits its eggs in crows' nests, the Bronze Cuckoo (Lamprococcyx), which selects small, dome-shaped nests, and the Black-eared Cuckoo (Mesocalius osculans).

\section{The Wrens and Warblers}

In a general sketch of this kind a number of the perching birds are unavoidably omitted, as, for instance, the three Orioles (Mimeta), the Ground Dove (Cinctosoma), and

1 Wheelwright: Bush Wanderings of a Naturalist. 
other Ground Thrushes, with the songless Mountain Thrush of Tasmania and allied Pitta, a noisy bird that may be seen and heard in the Insect House at Regent's Park, the insectivorous Pomatorhinus and Zosterops ("White Eye"), and four species of Sitella which, except that they do not lay their eggs in hollow trees, bear some resemblance to our nuthatch.

Indeed, I can only find room for half a dozen more families.

The Wrens and Warblers - chiefly Maluri, with the allied Amytis and Stipiturus - are purely Australian. They are feeble on the wing but swift of foot, as indeed one would guess from the long legs and puny wings; and all build, like our wren, dome-shaped nests, many sizes too large, to all appearance, for such small occupants, and much beloved of the bronze cuckoo, to whose chicks they are often fosterparents.

Somewhat shy during the breeding season, when the male bird dons his gaier raiment, they are tame and fearless in winter. The best known, out of nearly twenty species, are undoubtedly the graceful little Emu Wren (Stipiturus malachurus), so called from the five long feathers that adorn its tail, and the "Blue Wren" or Superb Warbler (Malurus cyaneus), both of which I have repeatedly watched in the Sydney Botanic Gardens, opposite which I lived for nearly six months.

They dart about the pathways like mice, but rarely seem to fly.

There are a dozen other Superb Warblers, only three of which need be separately mentioned, $M$. longicaudus of Tasmania, and two species from Western Australia, $M$. pulcherrimus and $M$. splendens, the latter with bright metallic lustre on the plumage.

The remaining Wrens are three in number: Amytis 
textilis, whose grotesque movements Gould happily compares to those of a rubber ball; A. striatus of New South Wales, and A. macrourus of Western Australia.

\section{The Diamond Birds}

This peculiarly Australian family comprises half a dozen birds, one confined to Tasmania, others to the mainland.

The majority of them lay their eggs on a bed of grasses in some hollow tree; but the Spotted Diamond Bird (Pardalotus punctatus), known to the aboriginals from its peculiar cry as the "Weedupwee," burrows in the earth, Here, at the end of a long, dark passage, tunnelled two or three feet beneath the surface, and so placed that water can flood the approach without reaching the eggs, is its carefully constructed nest, lined with the finest eucalyptus bark.

The "Forty Spot" (P. quadragintus) of Tasmania nests in a hollow spout high up in the gums; $P$. striatus, on the other hand, is not found in that colony; $P$. affinis occurs both there and on the mainland; P.rubricatus throughout the southern colonies; P. uropygialis and P. melanocephalus recorded only from Queensland.

\section{The Rifle Birds}

Australia has, strangely enough, no woodpeckers, though scarcely for the reason, absence of suitable food, suggested by Gould, for their place is taken by the beautiful Rifle Birds, which run up and down the lofty trunks, from which they dig out lurking grubs.

The antics of these three birds-the Yass (Ptilorhis paradisea) and the more northern $P$. victorice and Craspedophora magnifica, the latter also found in New Guinea-are sure to attract the visitor's attention. 
They have been compared with that elegant Batchian bird-of-paradise known as Wallace's Standard Wing.

Like the six Tree Creepers (Climacteres), these birds are not found in Tasmania.

\section{The Finches}

The Finches, so-called, are another purely Australian group, including a score of species. A fellow-passenger on my ship recently brought home fifty of these birds from Cairns (N.Q.), and, thanks to his untiring patience in ministering to their wants from sunrise till evening, not one came to grief. A few folks there are specially gifted by nature to keep creatures in captivity, and this gentleman was of these.

All the Australian finches construct a large nest in the densest portions of the low trees.

Tasmania seems to have but one, the Fire tail (Zonceginthus bellus), which seems to be confined to that colony, and is allied to the "Native Sparrow" of West Australia, distinguished by some red markings about the head. Of the dozen finches found in New South Wales, the Red-bill (Aegintha temporalis) is not uncommon near Sydney, and the Plain Finch (Ardemosyne modesta) and Red-tail (Bathilda ruficauda) both occur in the Liverpool Range, a most important zoological district.

The six Grass Finches, (Poëphila) as also the Painted Finch (Emblema picta) and two species of Donacola, occur chiefly in the northern districts. It was to the Painted Finches, ${ }^{1}$ distinguished by long and pointed beaks, that the above-mentioned travellers mostly belonged.

1 The disinterested dealers confuse several commoner kinds under this name. 


\section{The Flycatchers}

These little birds (Muscicapida) are much given to perching on some fallen log and flirting their tail, not vertically like our magpies and wagtails, but from side to side in a way almost unknown among British birds.

The bill, slightly hooked at the tip, is armed with bristles that doubtless aid in the capture of flying insects, the latter being seized, by all except the Carinated Flycatcher (Monarcha carinata), on the wing, the bird retiring to its perch to feed at leisure. In the roofing of their nests, which our flycatchers bind with horsehair, the Australian birds use a still finer thatch in the shape of cobweb.

Among the most interesting of the group are the Redfronted Fantail (Rtidipura rufifrons) of New South Wales, the swiftest runner of all ; and the White Shafted (R. albiscapa) species, found throughout the mainland and Tasmania, a fearless little bird that constructs a beautiful cup-shaped nest lined with moss and fine eucalyptus bark. The northern Fantail (R. isura) also builds a cup-shaped nest bound with cobwebs; and the Black Fantail (Sauloprocta), or "Stock-Whip Bird," which is not found in Tasmania, bears a marked resemblance to our wagtails. The "Grinder" (Seisura inquieta) is not uncommon in the neighbourhood of Sydney, where I have seen it shot as it hovered, uttering a grating note, over some insect. In the same family, mention must be made of the Shining Flycatcher ${ }^{1}$ (Piezorlynnchus nitidus) of Queensland, and the tuneful Brown Flycatcher (Micrceca fascinans) of the south coast.

1 There is another Shining Flycatcher (Myiagra) in Tasmania. 


\section{The Shrikes}

Of the Shrikes, or Butcher Birds, Australia has a number, all more or less with the habits of our Grey Shrike, the "Watchman" of fowlers.

Chief among them are the Crow-Shrikes, or "Piping Crows," familiar at the Zoological Gardens, which include the Piping Crow-Shrike (Gymnorhina tibicen), or Magpie, a favourite cage bird with the colonists. It lacks the long tail, and perhaps some of the beauty, of the English magpie ; but the voice is far sweeter and the bird has some powers of mimicry. Unlike the more generally distributed Pied Crow-Shrike (Strepera graculina), it is little met with out of New South Wales.

To the same family belong the Black Magpie ( $S$. fuliginosa); the Swan River "Squeaker" (S. anaphorensis); the White-backed (Gymnorhina leuconota) bird of Victoria and allied White Magpie of Tasmania ; the Black-throated (Cracticus nigrogularis) species of Sydney, and similar, though smaller, (C. picatus) of northern Queensland; the Butcher Bird (C. torquatus) of West Australia, and a number of others.

And lastly, several types not peculiarly Australian, such as half a dozen Grauculi, ten Thickheads, six so-called "Shrike-Thrushes," and two "Shrike-Tits."

\section{The Robins}

The Redbreast (Petroica multicolor), the Guba of the aboriginals, which we find in Australia is not our bird of many traditions, though a near relation. Indeed, it is unmistakably a smaller bird with a much feebler voice, and its nest is in trees and not beneath some shelving bank. 
Then there is the scarcer Red-Capped bird and the Yellow Robin (Eopsaltria) which one sees in the Sydney Gardens.

The Black Robin (Melanodryas), a fairly common species in New South Wales, which may be seen chasing its insect food much after the manner of the fantails, is not met with in Tasmania; but that culony has, on the other hand, in the Dusky Robin (Amaurodryas), a species of its own. This dull-coloured little bird builds its nest on the rocky cliffs.

And on the north-west coast we have two kinds of Precilodryas and two Scrub Robins (Drymodes).

Which concludes the Perchers. 


\section{Part IV.-BIRDS OF PREY}

\section{BIRDS OF PREY}

\section{Eagles}

THE absence of large mammals, more especially of large carnivora, from whose meals there is generally enough left for these scavengers of the air, accounts for the paucity of Australian eagles; and in New Zealand, where there is no indigenous mammal larger than a rat, we find, with the exception of an occasional sea-eagle, a straggler from other coasts, nothing greater than small kites and harriers. Thus, the Raptores of that land are by no means as interesting a group as in other parts of the world.

The Sea-Eagles are of two genera-Halicetus and Haliastur-both of which contain but a single species. In both, too, as in most of the birds of prey, the female is by far the larger bird of the two.

The first of these, the "Fish Hawk," or White-Bellied Sea Eagle, (Haticetus leucogaster), I saw wheeling over dead fish when the muddy banks of the Derwent were uncovered by the ebbing water; and a splendid pair of the 
more northern bird (Hatiastur leucosternus) circled over our steamer in Cleveland Bay and finally disappeared over the heights behind Townsville.

Both species lay their two eggs about August or September in a straggling nest of sticks placed on some inaccessible tree or ledge.

The northern species is said to be far more skilful than the other in capturing fish in its claws and to feed, in consequence, much less on carrion.

One of the most common among Australian birds of prey is the Whistling Eagle, or "Whistling Hawk," (Milvus sphenurus), by no means a large bird, which feeds principally on mice and small lizards. I once saw six of them, in company with kites and hawks, poised over a bush-fire in Queensland, and evidently on the look-out for such small mammals as might be driven forth, half stupefied, by the pungent smoke. The eagles kept at a greater altitude than the smaller birds, whistling all the while, and always well out of range. According to Gould, this eagle does not occur in Tasmania. I think there were a pair, however, in the Hobart Museum, though possibly not in the local collection.

The Wedge-tailed Eagle (Aquila audax), or "EagleHawk" of Victoria, is a splendid bird, not unlike the Golden Eagle, though smaller. By no means very shy, it is easily approached when gorged from a recent feed; and there is a case on record in which one of these birds attacked some of the pioneers in the old days, under the impression perhaps that they were some nerv species of kangaroo, an animal which, as also the bustard, they hunt freely. They. will also follow kangaroo-hunters for days together; and when the kangaroo gets scarce they turn their attention to lambs, or even carrion does not come amiss. They are therefore a trouble to the already handi- 
capped farmer, and, as already mentioned, the governments expend large sums for their destruction.

The large, straggling nest is placed in the fork of some lofty gum, out of reach of every one but a black boy. There are three or four of these birds at Regent's Park, which have frequently laid their dull white eggs splashed with brown; but, like most captive eagles, they look a little off colour, the eyes alone retaining their native fierceness.

Quite different are the splendid monarchs of air which float in pairs over the creeks and gulleys of the Blue Mountains.

\section{Hawks and Kites}

Many of the smaller birds of prey that do their work by day are so common in Australia, more especially on the coast and in estuaries, that one gets sick even of shooting them. And indeed, in that climate of speedy decay they are best let alone. There is plenty of work for them.

The 0sprey, or "Fish Hawk" 1 (Pandion leucocephalus) is considered common, I believe, in the southern colonies, but, although my fishing expeditions both inland and along the sea-shore should have taken me past its haunts, I was never lucky enough to see it out of the museums. It is said, however, to hawk over the beaches near Sydney.

Of Kites there are four. The most common, the Allied Kite (Milvus affinis), does not occur in Tasmania. Unlike the majority of the order, there is little or no difference in the size of the sexes.

The Square-tailed Kite (M. isurus) is easily distinguished by its white rump.

There are five Goshawks, the White species, which feeds largely on the "native pheasant," being, especially in Tasmania, the most abundant.

${ }^{1}$ A name also applied to Haliaetus leucogaster. 
The Brown Hawk is common and, unless represented by a bird of similar appearance, occurs throughout the continent. Its food consists largely of caterpillars. Gould differs from Kaup in regarding Hieracidea berigora and $H$. occidentalis as distinct species instead of mere varieties.

I never to my knowledge handled the more southern species, but a good many which I shot in the Queensland rivers answered closely to Gould's description of it.

Of the four Australian Falcons, the Grey is, speaking generally, and not of individual districts, the rarest, and the Blue Hawk the most common, the latter being a pretty little bird which dashes, like the peregrine, down the creeks after the wild duck that its bright yellow eye has spied from afar.

The "Sparrow Hawk," the Bil-bil of the aboriginals, is common round Sydney and Melbourne and in the southern districts generally.

There are two Harriers. Jardine's Harrier breeds near Sydney in the summer months, and the Allied Harrier, known in some parts as the "Swamp Harrier," preys, like our Marsh Harrier, on water-fowl.

There is but one Buzzard (Buteo), only found in the central and southern districts and exceedingly scarce in the settled parts. The aboriginals have a tale that the bird drives the emu from her nest and forthwith soars over the eggs with a large stone, which it drops upon them, feeding anon upon the contents, an unnecessary and roundabout proceeding that would never occur to a bird with a beak of such strength. The aboriginals have a good many yarns of unnatural history. As for their woodlore, Gould mentions that they have but one name for the emu-wren and several species of superb warbler; and up in Queensland I found the word "barramunda" applied indiscriminately to such 
large fish as the Giant Perch of the Fitzroy, the "Palmer" of the Mackay, and even the Ceratodus of the Mary and Burnett.

\section{0wls}

In Strigida, Australia with only about ten species, compares badly with other lands.

The best known of these is the Brown 0wl, or Boobook, known in some districts from its monotonous cry as the Cuckoo 0wl. In fact, it is the so-called " night-cuckoo" of many writers. ${ }^{1}$

Another familiar owl of that country is Strix delicatulus, which has the noiseless flight and general appearance of our Barn 0wl.

Strix castanops is the only species at all common in Tasmania, where it may be seen perched of a bright night on decayed stumps. Those who aspire to illustrate natural history works or mount specimens for the museum will do well to bear in mind that owls perch with two nails only in front of the support, and not with three.

No eared ${ }^{2}$ owls have as yet been described from Australia.

1 The author of Australia As It Is (1894) says (p. 22), "The cuckoo is only heard at night."

2 The so-called ears are only ornamental tufts of feathers, the real ears being lower down. 


\section{PART V.-SCRATCHING BIRDS}

\section{SCRATCHING BIRDS}

OF these Rasores, of which a humble but useful type is furnished in the common hen as she scratches up the loose earth of the chickenhouse honeycombed by many rats, Australia has two great families, the Pigeons and the Megapodes, the most numerous and most interesting respectively of all her birds.

\section{The Pigeons}

But for certain wise and paternal edicts against Sunday shooting, some of the elegant pigeons that breed within easy distance of Sydney would long ago have become extinct, in such favour are they with local pothunters. The wealth of Australian pigeons will be appreciated from the fact that nearly half of the species known to science occur nowhere outside that region. Indeed, there are upwards of two dozen, about one-third of which, feeding almost exclusively on figs and palm-nuts, are known as FruitPigeons and are best for table purposes, though I always thought some of them, especially that destructive favourite the Top Knot (Lopholaimus), the poorest of eating. 
The male bird is invariably the larger, and the one-or there are at most two - white egg is deposited on an almost flat platform of loosely interlaced twigs.

One of the best for eating is the delicate Wonga-Wonga (Leucosarcia picata), of New South Wales, a pigeon with delicious white flesh, which I have seen near Sydney, running about the clearings, and apparently picking up seeds and fallen berries. It seems to live most of its time on the ground, being feebler on the wing than most of the family. Pity it is that so excellent a pigeon should not have been acclimatised ere this in the old country.

If there is a better eating pigeon than the Wonga, it is surely the Torres Strait, or White Nutmeg pigeon (Myristicivora spilorrhoa), the latter name being in allusion to its favourite food. Unlike the last species, this pigeon is rarely seen on the ground. I saw numbers on the northeast coast, but got no chance of a shot. Some, however, which the company's agent sent aboard at Thursday Island were much appreciated as a change in the saloon bill of fare. The bird had only arrived sparingly, it being then somewhat early in the season. According to Saville Kent ${ }^{1}$ the bird nests in the mangrove trees on the coast, laying two white eggs, whereas Gilbert found only one. ${ }^{2}$ It is generally said, with what foundation I am unable to say, that these wild pigeons exhibit a constancy in their attachments unknown in our domestic doves, whose emblematic fidelity is, as all know who have kept them, purely mythical.

Wallace, ${ }^{3}$ in one of those beautiful passages of generalising at which he is so happy, points out the dull green backs of the majority of these gay-coloured Australian pigeons as another instance of the thoughtful provision of

1 The Great Barrier Reef of Austratia (p. 123).

2 Gould: The Birds of Australia.

${ }^{3}$ Geographical Distribution of Animals, vol. i., p. 395. 
nature. They thus escape the keen-eyed hawks that abound in the same localities, ever hovering over the Queensland mangroves on the look out for a meal; whereas in those species occurring in some of the smaller Pacific islands that are rarely visited by such marauders, the gay colours appear on the back as well.

The large White-headed Fruit Pigeon (Leucomeloena) is also plentiful near Sydney, and in smaller numbers one sees the Magnificent species (Megaloprepia), still more often hearing its loud, harsh note.

I now come to the terrestrial Bronzewings of Australia, which are also excellent eating, especially the seed-eating Partridge Bronzewing (Geophaps). I recollect a naturalist showing me the curious lactation of the crop in a dissected male of this species, which doubtless gave rise (in European kinds) to the old April fool's errand of buying pigeon's milk.

All the bronzewings seek water at sundown, and sportsmen lie in ambush for them near the creeks and waterholes. Some travellers suggest, facetiously maybe, this habit as a means of finding water when pitching one's camp for the night. The wanderer is to follow the birds until the water is reached. As their rate of travel however, is something over sixty miles an hour, the suggestion savours of the ancients.

The common Bronzewing (Phaps chalcoptera), only a migrant in Western Australia, occurs in all the colonies; while the allied bird $P$. elegans is restricted to the south-east.

The crested Ocyphaps is a beautiful little pigeon-in the museum. I never saw it al fresco, though it seems plentiful enough in the interior. That a bird of such great power of flight should be restricted within the coast ranges, seaward of which it rarely strays, seems somewhat remarkable. 
Two other Australian pigeons must be mentioned, the long-tailed Macropygia of the south-east coast, and the white-quilled Petrophassa of the north-west.

There remain of the Columbidae but four Doves, including two species of Geopelia (G. placida and G. tranquilla), found chiefly in the north, and two other birds, known respectively as the Barred-shouldered and Little Turtle Doves, names that certainly fit them better, at all events for English-speaking folks, than those heartrending words of six syllables manufactured in the dissecting-room for the slander of an innocent race.

\section{The Megapodes or Mound-Builders}

In a brief survey like the present of Australian bird life, one is reminded of the "positively last appearance" of famous singers.

The temptation is strong upon their biographer to designate more than one of the feathered families of the bush as positively the most wonderful.

The lyre-birds seemed in all conscience singular enough ; and Nature seems to have exercised her fancy somewhat freely when she produced the bower-builder, the grotesque kingfisher that has abandoned the haunts and food of its race, the swarming wood-swallows, or the burrowing mutton-bird.

But truly, I think the most remarkable of all is the group under notice in this concluding chapter on the birds.

It is unnecessary to discuss the allied ground-birds that form the bulk of Australian indigenous "game," the Stubble Quail (Coturnix pectoralis), the four Swamp Quails, the Painted Quail (Turnix varius) of the south, the Thick-bellied Quail (T'. castanotus) of Queensland, the 
tiny Exfalcatoria, and the rest. They are fully described by Gould ; and their habits, so far as the sportsman at all events is concerned, are the same as those of all quail, the swift running in the long grass, the sudden crouching until almost trodden upon, the reluctance to rise so long as escape is possible in any other way.

But the singular Mound-Builders, which bear some

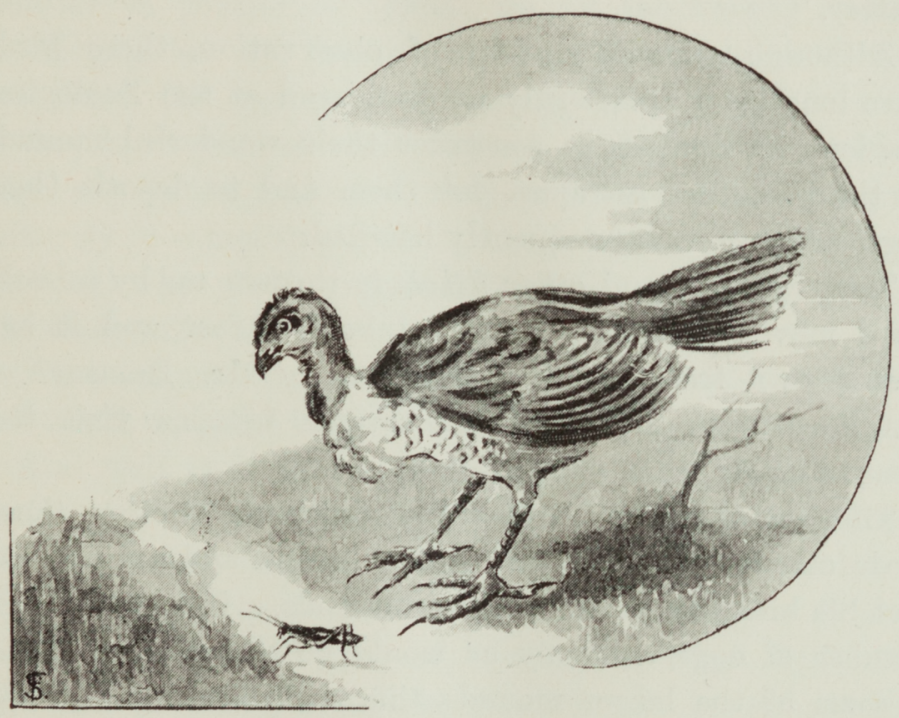

Brush Turkey.

resemblance to the Curassows of South America, may truly rank among the bird-wonders of the world.

They are found also in New Guinea, and several other islands, and were reported as inhabiting the Philippines almost two hundred years before Australia was heard of.

Yet in Australia they have perhaps their home, and at all events it is from that country that we have learnt almost all that is known of their haunts and habits. 
Like the ostrich and cuckoo these most interesting birds do not incubate their eggs. Here, however, all resemblance ends; for instead of leaving their eggs to the sun or to foster parents of alien blood, we find them deposited in a perfectly planned, thoroughly heated incubator. Even its ventilation is not overlooked, for a shaft is found in most of the mounds, evidently allowing the escape of noxious gases generated by the decomposing vegetable matter.

Although exceedingly shy of observation, these birds have long been sufficiently domesticated at the Zoological Gardens in London to construct their wonderful mounds in the enclosure set apart for them and to deposit their eggs, which were subsequently hatched.

The vegetable and other débris is thrown up by a back. ward movement of the powerful hooked feet, and it has been shown from actual observation by Mr. Ramsay ${ }^{1}$ of the Australian Museum that several females visit the same mound.

This set at rest a long vexed question, whether these birds collaborated, like the fairy-martins and some other sociable birds, in building these mounds. From the large number of eggs, as many as would go to a bushel, found in some of the larger mounds, this co-operation had long been suspected, as it seemed natural that the enormous structures might, as with the common guinea-fowl, serve as safe-deposits for several hens.

The aboriginals, however, repeatedly denied this, so that Mr. Ramsay's conclusive evidence was welcome.

The mounds vary greatly in size. The circumference at the base is in some cases as much as thirty or forty feet, the structure tapering to the height of two or three feet in that of the Native Pheasant or "Mallee Hen" (Leipoa ocellata)

1 Proc. Zool. Soc., xliv. 117. 
to five or six times the height in the gigantic monuments of the Brush-Turkey (Tallegallus) and Jungle-Fowl (Megapodius).

In the warm interior of these incubators are laid a large number of long, thin-shelled eggs, so placed in a ring as to receive equal heat from the decaying matter below, and no two in contact. The smaller ends rest downwards, just like the plovers' eggs on the round racks familiar in poulterers' shops. In all the twenty species of Megapodes at present known, of which Australia has three, the young leave the egg fledged, and as soon as they have worked their way out of the mound, assisted some say by the male bird, they are able to fly, arriving at maturity in something under three months. But although they will when hotly pursued fly into a tree, they prefer, like their allies the quails, running.

One contrasts the advanced state in which they enter the world with the helpless early days of the marsupials.

And well it is so, for their parents take absolutely no notice of them when hatched, which differs strangely from the solicitude with which they visit the eggs beforehand. More particularly is its early maturing a boon to the chick of the aforementioned species described from the Philippines, which is said to construct its mound on the shore, deposit its eggs and then wander off to pastures new, troubling no more about them.

And Nature is not forgetful of the young, having devised one of her many wondrous schemes for supplying them with congenial food $a b$ ovo. For it is mercifully ordained that the white-ant, which frequents these mounds in such hordes that more than one traveller has mistaken them for ant-hills, just as others took them at first to be aboriginal graves, shall particularly like crawling over the egg-shells, so as to be ready when wanted. 
The ventilation of these mounds has already been mentioned, and the birds give one further proof of their wonderful instinct by always erecting their mounds in the shade, so that the sun shall not dry the decaying vegetable matter within.

To which few remarks on the curious habits of the group collectively, little need be added in respect of the individual characters of its three Australian members.

The Brush Turkey (Tallegallus) is specifically named after Latham, who called it for some reason or other the "New Holland Vulture," an error which he lived to correct. It is distinguished by a bright yellow wattle conspicuous against the red neck, but less so in the female. The brown legs and claws are exceedingly powerful. As a curious instance of stupidity in a bird of intelligence otherwise remarkable, when a number are perched in the topmost boughs of some lofty tree, it is possible to bring them down one after another without their taking fright. The bird is found in Queensland and New South Wales.

The Native Pheasant (Leipoa ocellata), or Mallee Hen, is a native of the southern plains. By far the most attractive of the megapodes, with its elegant black and white plumage, it has, unlike the last species, the head and neck thickly feathered.

And lastly, the Jungle Fowl (Megapodius tumulus) of the north is essentially a coast bird. It is to this genus that the bird of the Philippines belonged.

All these megapodes, slow on the wing, feed entirely on the ground, berries and beetles forming their chief food.

With which, not wishing to devote to them more space than I did to the mammals, I must conclude this necessarily short sketch of Australia's birds. 


\section{REPTILES}





\section{INTRODUCTORY}

I cone now to that more lowly class of beings usually regarded, in spite of the protest of a few intelligent champions, with loathing. "Snake in the grass" or "Viper," is an expression which has in its figurative meaning about as much value as the epithet "duck" (the dirtiest of birds) as a term of endearment, "lion" as the equivalent of bravery, "ass" or "goose" as that of stupidity.

To Miss Hopley and Dr. Stradling I must refer the reader for a defence of this class as personified by snakes. I have not room here to say all I would on the subject; but it is just worth mentioning that I recently travelled over seventy days, sharing my cabin with a large Diamond Snake (Morelia spilotes) and a Jew Lizard (Agama muricata), without there being a single breach of the peace all the way from Sydney to Plymouth. I presented them, on my return, to the Zoo, where the snake is, I believe, still flourishing. The lizard unfortunately died, about two months after its arrival, in violent convulsions.

Like whales, these reptiles are a dying race, and few casual observers would guess how nearly they are related to the graceful birds.

"A monstrous eft was of old the lord and master of earth,"

as the dead laureate had it; but their race is run, 
their giants are no more, and the fair earth is the heritage of the birds and mammals. The flying dragons feebly parody the higher type, but they too will disappear in due course. For their place is with the pterodactyle in the museum.

Those who associate reptiles with damp localities will be surprised at the wealth of them in Australia, especially in the desert, far from water of any kind. Of its snakes, by far the greater number are poisonous, the proportion throughout the continent averaging three to one, while in South Australia we find six poisonous to one innocuous snake. Again, Tasmania has only three snakes, all of which are poisonous.

It is as well, however, to explain at the outset that these are by no means necessarily dangerous. Many Australian species, indeed, possess a poison fang without being at all deadly. In some of these the fang is too short to do much damage; in others, as the sea-snakes, there is simply no disposition to bite.

In New Zealand, as in a few other islands in either hemisphere, not a land snake is to be found, and their introduction is strictly forbidden under heavy penalties.

The people of the south are beginning to profit by the experience they bought so dearly.

Of Lizards, however, New Zealand has some variety, notably the remarkable Tuatera (Sphenodon), of the Maoris, sole survivor of an extinct order, and their Atua (Naultinus), an exquisite green lizard with gold spots ; and sea-snakes are plentiful on the coast. 


\section{PART I.-SNAKES}

\section{SNAKES}

IT is not my intention to give any detailed account of this remarkable order or to correct any of the widespread errors concerning the habits, reproduction and disposition of snakes. Such themes can only be touched on incidentally in a short account of that highly specialised fauna with which we are concerned. The questions of greatest moment to all who are likely to visit the bush are first, the actual danger run of being bitten by the poisonous snakes that occur most frequently, and secondly, the best means of distinguishing them from the harmless kinds. For their own sake, that they may not carelessly, as at home, sit on decayed logs or thrust their hands into every nest or burrow. For the sake of some of the harmless and beautiful reptiles, which too many go forth and kill, raising gun or stock whip at anything in serpentine form.

Yet killing the harmless rock Pythons-I use the, word on the authority of Krefft, though it applies more strictly to a family of Indian serpents - is not only wanton cruelty, but in a land afflicted with rabbits the lieight of folly, as 
these rodents have no greater enemy than the Diamond ${ }^{1}$ and Carpet Snakes.

Of the morals of snakes, especially their alleged malice much has been written. They take no pleasure in inflicting pain. With the exception indeed of the aggressive Fer-delance of Brazil and one or two other species, there is no single snake in the world, certainly none in Australia, that will attack unless trodden upon or cornered, and there are but very few (the Australian Death, or Deaf, Adder is among them) that do not when disturbed show great anxiety to vanish. I have come across them, venomous and others, in several lands, basking in the hot sand, lying on the mossgrown rocks or across the road, hanging from trees or motionless on the water, and do not hesitate in pronouncing this timidity characteristic, with few exceptions, of the whole tribe. They invariably hurry off to keep a pressing appointment elsewhere. Snakes, liko wallabies, seem to vanish into thin air. I never attempted to discover whither. It would have been useless. Nor did I ever feel called upon to interfere with their arrangements for making themselves scarce. Their motives seemed, like their fangs, worthy of respect. They are said to be abnormally aggressive at the breeding time, but I never found any truth in the statement. And surely the best evidence of the peaceful disposition of these maligned creatures is furnished by a comparison between the rarity with which cases of death from snakebite occur and the carelessness of colonials in the bush, marching through the long grass without topboots, and picking up any decayed log with never a thought

1 This forbearance must not, however, be exercised towards the so-called Diamond Snake (Hoplocephalus superbus) of Tasmania, a highly dangerous species. As is also the "Diamond Snake" of America, one of the most venomous of rattlesnakes. The so-called Carpet Snake of Tasmania is the deadly Victorian Tiger Snake. 
of what may lurk within. Unfortunately, the snake hardly gets fair play, so many writers having a weakness for making "sensational copy" out of their snakes and sharks.

"How I avoided being bitten," says the author of that excellent little record Bush Wanderings of a Naturalist, " is a mystery to me. . . . I once threw myself on my blankets for a rest . . . and a large carpet-snake lay curled up within three inches of me."

He might perhaps have felt surprised, had he seen me during two cold November nights in the Bay of Biscay with a $6 \mathrm{ft}$. specimen of the similar, if not identical, diamond snake in my bunk, that the cold might not kill it. In no way, though it had not had a pigeon for a fortnight, did it trespass on my hospitality. The fact is, these boas are almost as harmless as those worn by the fair sex; indeed in Euston Station may be seen, as I write, photographs of Dr. Stradling and his son with these fascinating pets around their necks.

This particular snake of mine had ten rather formidable teeth; but a nip in the hand from a small python is no very serious matter, if only you have the presence of mind, instead of foolishly tearing your hand away and lacerating the flesh against the incurved teeth, to administer a smart pinch in the back of the creature's neck, when it at once relaxes its grip, leaving only a few small punctures. To make quite sure, it is a good plan to open these with a clean lancet and bathe with carbolic, as even in nonpoisonous snakes the teeth may be dirty from a recent feed, and a bad hand might result.

The snake's power of fascinating birds is another moot point, on which Dr. Stradling has offered about the best suggestion, fully endorsed in Miss Hopley's charming book. His opinion is that the birds mistake the quivering tongue 
for a worm or insect, and that organ, considered by the ignorant to be endowed with "stinging" powers, may consequently act as a bait to lure the incautious fowl within reach of the fatal jaws. This theory has much to commend it, especially as the tongue is the one part of the snake in motion, the rest being only with difficulty distinguished from the earth on which it rests.

One piece of evidence occurs to me in connection with this alleged power of fascination, which I give for what it is worth. At Batavia and Colombo, both cities, be it remarked, in the centre of snake country, I had to buy some pigeons for my compagnon de voyage. It went against the grain, this feeding it on live birds; but the snake was a rather valuable one, and had to be got to England alive at any cost. Well, the pigeons were absolutely fearless when introduced into its box, perching on the motionless head and heaving coils. Of a sudden, a lightning movement, and before the observer quite realised what had happened, a bunch of feathers lay enveloped in a coil, and there was death in the box. After a delay of a few moments, without any of the alleged lubrication with saliva, the victim was swallowed head first. Frogs are seized by the hind-leg, and the head is last to disappear.

At the risk of being trite, it is as well to explain, for the benefit of those who have not seen them at large, that snakes are usually found either coiled in a pyramid, the head resting on the top, or extended at full length in the sun. It is perhaps unnecessary to repeat the fact on which every writer on the subject has laid stress, that their undulations are naturally lateral and not, like those of the fabulous "hoop" snake, formerly supposed to chase horsemen over the plains, in a vertical direction.

But the questions, as already suggested, of most immediate interest to the "new chum" are how best to 
distinguish the venomous snakes and deal with any bite they may inflict.

On the last head, our knowledge is unfortunately still most imperfect. Medical men have not been so happy in their treatment of snake-bite as with the majority of human ailments. The unfailing remedy has yet to be discovered. Even the general treatment in the way of immediate relief is to some extent a matter of opinion; and authorities are agreed only on such precautionary measures as freely lancing the punctures and thoroughly sucking them ; tying a ligature tightly above the wound; internal and external application of strong ammonia; and dosing the sufferer, who should be kept walking up and down, with stimulants. Two essentials are always insisted on: keeping the patient in good spirits and free from anything in the shape of depression, and great promptitude at all events in opening and sucking the wounds. The poison can be of course swallowed without danger, providing the mouth is free of cuts or sores.

Pending the further enlightenment of the faculty, it is some consolation to know that the poisonous snakes of Australia are by no means as aggressive as they are plentiful.

The method most in vogue of determining whether a snake is venomous or the reverse, is to shoot it first and examine it at leisure ; and it must in fairness be admitted that the tests suggested by writers on the subject commend themselves but little to the cautious.

The wayfarer can, for instance, scarcely be counselled in earnest to grasp a small tiger-snake or death-adder in order that he may count the number of plates upon its abdomen.

It is interesting, no doubt, to know that snakes with over two hundred and forty of these plates are harmless, but the interest is strictly confined to those which have 
been put out of the way of doing any further mischief; though even in handling venomous snakes after death, extreme care is requisite to avoid the fangs.

Nor would any but a veritable enthusiast care about minute investigation of the groove or slot in the dangerous region of the lower jaw, or of the horny spurs on the abdomen that are considered in the harmless pythons to represent rudimentary limbs.

The last straw occurs to me in the distinction pointed out by several authors, which is that poisonous snakes leave but two punctures and relax their hold at once, whereas the constrictors leave a number of marks and hold on until forcibly removed. This is a charming way of ascertaining the nature of any particular snake if a friend will assist; but when alone it becomes a question of experimenting on one's own person, which few will care about.

Australia has, strictly speaking, about sixty-five snakes, rather more than two-thirds of which are poisonous. Not one of them, however, is to be so dreaded as the Indian cobra, and they all burrow, or otherwise absent themselves, during quite half the year.

There are, it is true, few checks on snake life, but the monitor lizards, the laughing jackass, and the omnivorous aboriginals do some of the work of the absent peacock, secretary-bird, snake-eating hamadryad, mongoose, and wild-boar.

It is worth knowing that even the most deadly snakes can be carried with safety in a well-closed bag, as they make no attempt to bite through such a receptacle.

It is now necessary to consider briefly the individual species; first, the harmless, of which there are some fiveand-thirty ; secondly, the poisonous, over seventy, including the sea-snakes. 


\section{Harmless Snakes}

Australia has between thirty and forty harmless snakes, of which I proceed to enumerate the chief.

The Pythons first strangle their prey and, after a few moments, commence at the head and slowly devour it. After a good meal they seem to pass into a semi-torpid state, while the process of digestion is going forward. The other harmless snakes swallow the small mammals and birds alive.

Australia has no cannibal snakes like the Indian hamadryad.

Owing to the looseness of certain bones in the head, these pythons can open the jaws to an enormous extent, the upper and lower making an angle of something like $120^{\circ}$. The teeth, intended merely for seizing their prey and not for mastication, as they swallow it whole, are not fitted, like our own, in sockets.

The rock pythons can hang by their short prehensile tail from trees. They are the only snakes that incubate the eggs, the female depositing thirty in a pyramid round which she coils, her head resting on the top. It may be safely inferred that the embryo in the egg of these incubating species is less developed than in those, the hatching of which is left to the sun's heat.

The Diamond Snake (Morelic spilotes) is found only in the eastern portions of New South Wales, being represented throughout the rest of the continent by the somewhat larger Carpet Snake ( $M$. variegata), which some regard as a distinct species, though the majority are now inclined to look upon it as a variety only. Personally, I had always inclined to the former view, seeing that neither trespasses on the other's domain and that, colour differences apart, the carpet snake seems to attain to much greater dimensions. 
My faith was, however, quite recently shaken by Mr. G. Boulenger of the British Museum, who kindly showed me a skilfully arranged series of six, in which the transition from the typical yellow-spotted diamond snake to the other species, with the skin resembling that of the reticulated pythons, was so gradual as to be almost imperceptible.

So alike, at any rate, are the two creatures in haunts and habits, that they may be considered together. As already mentioned, the maximum recorded length of the carpet snake ( 15 or $16 \mathrm{ft}$.) is considerably in advance of that (11ft.) of the other kind.

The Diamond is a handsome snake, black throughout its length, the scales, which lie in fifty rows, being marked with a yellow spot in the centre of each, those on the under surface bearing a more or less marked resemblance to the shape of the diamond; hence the name. The skin looks at its best when new, immediately after the shedding of the old one; and it is generally stated that when this slough comes away piecemeal, the reptile is in bad health. The snake which I recently brought home, however, shed its coat in this way, starting at a bruised spot where a chair had fallen on it, and it is still in excellent condition.

These pythons, though nocturnal by preference, may often be seen in broad daylight basking in the sun, especially after a good feed, at which time they may be annexed without difficulty.

Both the Diamond and Carpet Snakes are of course endowed with the anal spurs aforementioned as characteristic of the pythons, and excellent climbing-spurs they must be, too, on the smooth trunks of the tall gum trees.

All snakes have a fondness for water, even lying in it, as well as for drinking, besides which they frequent the creeks and waterholes for the sake of the birds and water-rats upon which they feed. This reminds me to take the oppor- 
tunity of stating, even at the risk of flatly contradicting so high an authority as Schlegel, that some snakes at all events do drink, for I kept mine well supplied with water, and had the satisfaction of hearing it lap it up several times during the dark hours. Some folks are of opinion that snakes and parrots should be kept without water. It is a good thing for the snake that its tongue is forked by nature, else they might also split it, as they do that of the parrot, to make it talk!

Snakes are, as is well known, most delicate and uncertain in captivity, and sometimes die in the most unaccountable manner. I recollect a splendid Carpet Snake over ten feet, in the possession of Mr. McGarvie Smith, a Sydney bacteriologist. It had been in the best of health, though refusing food for months together; but I called one afternoon, having seen it in excellent condition only the day before, and found its sorrowing master already nailing the beautiful variegated skin out on a large dryingboard. A Carpet Snake of that size would swallow whole an opossum or even a small wallaby.

The two kinds of Morelia are the only harmless snakes much in evidence in Australia, though there are other. rock-snakes (Nardoa and Liasis) but little known.

The same applies to Aspidiotes or the Black-Headed Snake, the Ground-Snake (Coronella), and the eight little burrowing "Blind Snakes" (Typhlops), which in point of fact are not blind, and which feed almost entirely on ants. They include a Queensland (T. guentheri) and a West Australian species, some being toothless and laying their eggs in ant-hills.

Indeed, these harmless kinds are seen so rarely, that colonials may. well be pardoned for the promptness with which they kill everything in the form that proved too much for the philosophy of mother Eve. 
Somewhat more familiar are the Tree Snakes, more especially the Green Tree Snake (Dendrophis punctulata), a handsome green and white species common in New South Wales and South Australia, and also occurring, thongh more sparingly, in Queensland, in the northern districts of which it is represented by the allied $D$. calligastra.

Krefft points out a curious habit which this snake has of puffing out the neck vertically when irritated, while the venomous snakes inflate theirs horizontally. Its food consists of lizards, birds' eggs, and insects.

The Brown Tree Snake (Dipsas fusca), which grows to a length of 6ft, and feeds entirely at night, is, for all its formidable grooved tooth, perfectly harmless and gentle in disposition.

\section{Venomous Snakes}

I now come to the bulk of Australian snakes, the poisonous species. Once more let me say that the bite is deadly only in the minority of cases, the Brown Snake, Death Adder, and Black Snake being the most dreaded. Much depends in any case on the condition of both the snake and its victim; if the former has not inflicted a bite for some time, and if the latter is in bad health, then under these extreme conditions, and unless prompt treatment is effected, death is pretty certain to follow. The smallest of these poisonous snakes, Cacophis and others, are less noxious than hornets or wasps.

Nearly all the venomous snakes are viviparous ${ }^{1}$ the young, from fifteen to thirty in number, are brought forth about Christmas time. And all, with the exception of the sea-snakes, belong to the order Elapida, and are thus related to the dreaded cobra and hamadryad of India.

1 The genus Diemenia is oviparous. 
The erect, immovable fang is in most cases grooved in front, not perforated, as in many snakes.

In giving some slight description of the general colouring of the worst four individuals - the Death Adder, to wit, the Black Snake, Tasmanian Diamond Snake (i.e. the Copper Head of Victoria, or Large-scaled Snake [Krefft's name] of New South Wales), and the Tasmanian Black, or Carpet, Snake (alices Tiger Snake in Victoria, Brown-banded Snake of New South Wales, and Yellow, or Mallee, Snake in the Riverina ${ }^{1}$ ), I would take the opportunity of remarking that the hues change at various stages, particularly after casting the slough, when the spots and bands are always brighter and more pronounced. In museum catalogues, the species are usually described from spirit specimens, a mode of pickling which, however satisfactory, irreparably destroys certain colours in comparatively short time.

The Death Adder (Acanthopis) is a most repulsivelooking snake, lacking much of the gracefulness that characterises so many of its kind. Though not by any means the most venomous of its kind, it is yet sufficiently terrible to dispense with the additional halo of fable with which the traveller has more suo invested it-such, for instance, as the yarn of the curved end scale of the tail inflicting a deadly sting, or as Byrne puts it in his Twelve Years in the British Colonies (1848): "The adder may be included in the list of noxious reptiles, although it is not of the snake tribe; its great peculiarity is its deafness, which is so extreme that it is apparently unconscious of any sound whatever. In appearance it is most disgusting,

1 This district, the name of which recalls a maritime province in the south of Europe, is a vast inland tract of New South Wales, bounded on the north by the Darling and on the south by the Murray. 
with a thick, plump head out of proportion to the body, generally ten to fourteen inches long; its sting is contained within the point of the tail, and when it strikes a living object, the sting is inserted and the poison ejected on the moment; there is no remedy for the sting, death ensuing in the course of a few minutes."

As a matter of fact, this end scale is in most cases, and save in old specimens, quite soft.

One of this hideous creature's favourite positions is to lie, like the stinging weever dear to fishermen, buried up to the collar in the sand with only the head exposed. If anything could make a lover of snakes forswear the race, it would be the sight of a death-adder's head in that position.

Thus, it will bask until trodden upon or otherwise disturbed, when its movements are most rapid, as it can spring sidelong with great vigour. Its fangs are perforated like those of vipers, not grooved as in other Australian snakes.

By no means a large species, its greatest length is between two and three feet.

In colouring, it is grey and marked with a number of dark rings which spread from the neck to the yellow, compressed tip of the tail.

It occurs in every colony but Tasmania.

The Black Snake (Pseudechis porphyriacus), a much worse offender than the last, is generally found in the neighbourhood of water, in which, in its pursuit of frogs and water-rats, it swims with elegance.

The railway-traveller will not fail to notice that water tanks alone the line are carefully cleared of undergrowth for a considerable space. The object of this is to prevent accidents with hidden black snakes.

This handsome snake, with its black back and reddish 
abdomen, is of great size for a poisonous species, over $6 \mathrm{ft}$. being on record. When irritated, it flattens the neck, rises off the ground and strikes its victim. A variety (P. australis) also occurs on the east coast.

Of the genus Hoplocephalus, there are nearly a score of species, the chief being :

Hoplocephalus curtus, or the Brown-banded Snake, the local names of which have been given above. The maximum length is about $5 \mathrm{ft}$, ten feet in newspaper articles. It is the most venomous and aggressive of all Australian snakes, the latter quality, as well as the brown or yellow bands with which it is marked, having won for it the sobriquet of Tiger Snake, by which it is more generally known in the colonies.

The general colouring is greyish black with the aforesaid lighter bands, which vary greatly in depth and number. The lower surface is yellow. There are some smaller, harmless teeth beside the fangs, which, like the teeth of some sharks, lie back when at rest, but rise erect when business is intended. The neck is then flattened as in the last species. The young are born about Christmas, and number about twenty-five to thirty.

$H$. superbus, the aforementioned "Diamond Snake" of Tasmania, for which, to avoid confusion, Krefft suggested the alternative Large-scaled Snake, grows to a length of five or six feet, and is a deadly species, though less formidable perhaps than the last. The colour of this snake is brown or copper-coloured, the belly yellow to grey. It is also known as the Copper Head. There are red spots along the sides, and there is a V-like mark on the neck. The side scales are sometimes black and white. This snake is found in all the colonies except perhaps Queensland, where, if it occurs at all, it is confined to the southern portion. 
The third Tasmanian snake is the Whip-Snake (H. coronoides), and it is confined to that island, though it bears some resemblance to the South Australian species named after Masters.

The Brown Snake (Diemenia superciliosa) is the largest and perhaps the deadliest of Australian venomous snakes, five or six feet being on record. The prevailing colour is brown, of an olive tint, the belly yellow with brown spots. In some examples there are black bands. The brown snake is found all over Australia and New Guinea. Like its less noxious little congener the Whip Snake (D. reticulata) it is oviparous, but does not incubate as do the pythons.

South Australia is the headquarters of poisonous snakes and, as already mentioned, the proportion they bear in that colony to the innocuous kinds is as six to one.

In, or near, the desert we find $H$. ater, named after Flinders; a yellow species named after Gould; the dull brown $I I$. spectabilis of Port Lincoln; the Crowned Snake (II. coronatus), a frog-eating snake of the desert; and II. minor, a miniature edition of $H$. superbus.

The Broad-headed Snake (II. variegalus) is found only on the coast of New South Wales, and even there, owing to its burrowing and nocturnal habits, it is little known. I recollect seeing three turned out from under some loose stones near the golf-links at Bondi which measured only about two feet and were therefore in all probability not full grown. Though poisonous, the bite of this pretty little metallic snake is by no means fatal, being followed at most by slight headache with possibly sickness and local inflammation.

Such are the principal species of Hoplocephalus.

There remain the Black-bellied Snake (H. signatus) of the eastern districts; the Pale-headed Snake (H. pallidi. 
ceps); the Black-naped Snake (H. nigriceps) and the Black-backed species of New South Wales, the latter, remarkable for its white tongue, occurring also in Queens. land, and some few others.

These, however, are of slight importance, being small and unobtrusive, and inflicting moreover a bite of less significance than the sting of some of the large native wasps.

A very dangerous keel-scaled reptile on the other hand comes from the Clarence River district (N. S. W.) under the scientific name of Tropidechis carinata. It is of an olive green, light beneath, and marked with black rings.

One of the most beautiful snakes in the world is the Scarlet-spotted Snake (Brachysoma diadema) of northcentral Australia. Of a maximum length of eighteen or twenty inches, the upper surface is brown, covered with yellow spots, the belly yellow, and between the black head and the body is a strikingly beautiful scarlet collar.

The Banded Collared Snake (Pseudonaja nuchalis) of the north coast is a large dark olive species with broad black bands and yellow belly. It grows to a length of five or six feet, and can inflict a very dangerous bite.

Of other venomous land snakes, mention need be made of only the Ringed Snake (Vermicella annulata), found all over the continent, and the four species of Cacophis, comparatively harmless Queensland snakes.

\section{Water Snakes}

To some extent all snakes can swim, and a number of so-called water-snakes do not live in that element, but only take to it in pursuit of their prey or escape from their enemies.

In these, the nostrils will not be found on the upper surface of the head, as they are in the true water-snakes, 
There are a number of fresh-water snakes (Homalopsin $\propto$ ), more particularly in the Queensland rivers, which live chiefly on fish. One of the most common is known to science as Cerberus austratis. These rarely leave the water, and are viviparous.

The greater number, however, of Australian watersnakes are Sea-Snakes, which are also found in estuaries and even some miles up the rivers.

When angling in the Fitzroy and other northern streams, I have watched beautiful orange-banded ${ }^{1}$ black snakes gliding round my float, I was given to understand by some lightermen that these pretty creatures might be handled with impunity. But it would have wanted some care, involving the risk of upsetting my little dinghey, to ladle them out with my landing-net, and I knew that these Platuri are often dazzled by excess of light when removed from the water and strike blindly at anything handy. They are undesirable companions in such moods in a small boat.

These Hydrophiince swim entirely by the aid of their flattened, paddle-like tails and never leave the water.

Salt water is not, however, absolutely essential to their well-being, as they are met with far above the tidal portions of the rivers. In like manner, many fresh-water snakes come down to the sea at times for a change, just like eels.

In most of them we find the two poison-fangs, which are both grooved and perforated, supplemented by other teeth likewise grooved but not poisonous. The head is small, and the nostrils, with a single exception, are placed on the upper surface.

Unlike the terrestrial and fresh-water snakes, these

1 It is difficult to know whether to call these orange-banded black snakes or black-banded orange snakes. I think there is no rule, 
marine species cast the slough piecemeal and somewhat frequently, at irregular intervals. They are-viviparous, from four to nine young being born in the water. They feed on fish.

Hydrophis platurus is a handsome black and yellow species to which in all probability belonged my friends of the Fitzroy. Snakes vary greatly in the matter of colour, which is of little value in distinguishing species.

As many as eighteen solid teeth are found in some snakes of this family, to which belong the common $H$. elegans, growing to a length of four feet, and the larger $H$. stokesii of the north coast.

The principal sea-snakes that remain are as follows:-

Platurus scutctus, a black and white ringed species often washed ashore at Coogee and Bondi. The rings, varying in number from twenty-five to twice that number, are of little more value in determining the species than is the colouring.

There is another Platurus, named after Fischer. in the Torres Strait.

Australian seas have three species of Aipysurus, ranging in size from the little $A$. anguilliformis to the largest, $A$. levis, with a length of five or six feet.

A. fuscus is intermediate between the two.

The prevailing colour of these very poisonous sea-snakes, which occur mostly on the north coast, is a light brown with yellow bands or black spots.

The three or four colour varieties of that very common sea-snake Pelamis bicolor furnish a striking example of the little use of colouring for scientific distinctions. I have handled two examples at least that many would without hesitation have pronounced distinct snakes.

A large and handsome sea-snake is Disteira cyanocincta; and with the mention of two species of Emydo- 
cephatus and one of Acalyptus, the list of sea-snakes recorded from the Australian coasts may be closed.

They are without exception exceedingly graceful in the water, moving in that element without causing the slightest ripple, and more often extended like logs at the surface, where indeed I always preferred leaving them. No museum had requisitioned my services, and I always kept my love of natural history free of that extreme enthusiasm that courts snake-bite. And with due deference to Schlegel, all these sea-snakes, however gentle their disposition, are decidedly poisonous and best let alone. 


\section{PART II.-LIZARDS}

\section{LIZARDS.}

Australia is rich in Lizards, all harmless, though the large "iguanas" present when irritated a formidable appearance and can when further provoked inflict severe, though not poisonous, bites.

Like the crocodiles, they breathe by lungs. Though mostly terrestrial by habit, they will, if thrown into the water, swim well for short distances; and there are a few so-called water lizards, among them Physignathus lesueuri, which I have mistaken in the Queensland rivers for young crocodiles. $^{1}$

Australian lizards belong to seven families, of which the Aprasiida, Pygopodida, and Lialidae are not found elsewhere. The rest, as will be seen in the list that follows, belong to the Agamida, Gymnophthalmida, Scicnida, and Geckonida.

The chief Australian lizards are named in the list. A few notes are here given on some of the typical forms.

The Iguanas, the largest lizards now found in Aus-

i Krefft mentions a case in which a Grammatophora lived for upwards of an hour under water. 
tralia, ${ }^{1}$ grow to a length of six or eight feet, and are all distinguished by the remarkable dewlap, inflated when the creature is irritated, and the elongated body and whiplike tail. They pass much of their life in trees, round which they are most nimble at dodging the dogs. When cornered, however, they bite the animals severely.

The Moloch (Moloch horridus), a relation of the African Agamas, is a most formidable-looking creature, entirely covered with spines, the larger of which are hollow, and armed on the head with two spikes that suggest the profile of the two-horned rhinoceros.

Its appearance, however, belies the true nature of this lizard, which is of the gentlest, its food consisting entirely of insects. In colour, it is yellow with reddish patches.

The Stump Lizard (Trachysaurus rugosus) is equally hideous and inoffensive. This species, which may be seen in the Reptile House at Regent's Park, is brown with yellow spots, the belly being greyish with brown spots, and the palate black. It sleeps all day, and opens the jaws very wide when attacked. Though insectivorous and the reverse of aggressive, its bite is on occasion very severe.

The Bloodsucker, which is like a small iguana, is wrongly accused of inflicting a poisonous bite. ${ }^{2}$

Gymnodactylus platurus is a typical Gecko, able by the aid of its curious feet and notched tail to chase flies up a perpendicular wall.

Pygopus lepidopus, allied to the Pseudopus of Africa, is a snake-like lizard in which the hind legs are all but invisible. It is grey and spotted with white, the head having some black markings.

${ }^{1}$ Australian caves show remains of lizards 20 feet in length, and Africa has existing specimens that weigh $60 \mathrm{lbs}$.

2 I believe Heloderma (Mexico) is the only venomous lizard at present known. 
Varanus varius, a Lace Lizard (wrongly called Iguana), grows to a length of seven or eight feet, and feeds largely on carrion. It lays ten large eggs.

Tilique scincoides is without eyelids, like the serpents. The limbs are all feeble. It is olive bronze with a long blue tongue. In Western Australia it is known as the Pete.

Aprasia pulchella is another Western Australian lizard, limbless and snake-like. It is light brown in colour, with dark spots along the sides.

Lialis burtonii is a greenish brown lizard with a remarkable series of pores along the belly.

Grammatophora muricata, the short-tailed Jew Lizard, which grows to a length of eighteen or twenty inches, lives chiefly in trees, among the branches of which it moves with great rapidity.

The allied $G$. burbata has also a very short tail, and may be distinguished by the two horny excrescences on the head. The tongue and palate are yellow.

Chlamydosaurus kingii, or the Frilled Lizard, is common enough in New South Wales. Mr. Kent added one to the Reptile House a few weeks ago, but it soon died.

It will be seen from the following list that Australian lizards are largely skinks and geckoes; and the order is best represented in the colonies of Western and South ${ }^{1}$ Australia.

1 It must be borne in mind that, as already suggested, this is the only colony that extends so far north and south, so that its fauna is necessarily very rich. 


\section{AUSTRALIAN LIZARDS}

(Besides those already mentioned)

Geckoes.

Nephrurus asper (E. A.), brown with white tubercles.

Rhynchoedura ornata (N. S. W.), grey.

Gymnodactylus pelagicus (C. Y.), brown with dark bands.

G. miliusii (N. S. W.), brown with white bands.

Aelurosaurus brunneus, brown with transverse bars.

Heteronata binoei (W. A.).

II. derbiana (N. A.), brown with white tubercles.

II. eboracensis (C. Y.), grey with black spots.

Phyllodactylus marmoratus (W. A. and S. A.)

P. macrodactylus.

P. guentheri (N. W. coast), red with dark bands.

$P$. ocellatus (W. A.), brown with dark spots.

Diplodactylus ciliaris (N. A.), yellow with black markings.

D. spinigerus (N. A.), dark grey with black spots and tubercles.

D. strophurus (N. S. W.)

D. vittatus

D. polyoplethalmus (N. S. W.)

D. steindacheneri (N. S. W.)

D. pulcher (W. A.)

D. tessellatus.

Oedura marmorata (N. A.)

$O$. ocellata, with a bulbous tail.

O. robusta, light brown with dark rings.

O. lesueurii

O. rhombifera (N. A.)

O. verrillii

Gehyra variegata (W. A.), brown with dark streaks.

$G$. australis. 


\section{Pygopodid e.}

Cryptodelma nigriceps (W. A.), pink with black head.

C. orientalis (N. S. W.), a snake-like lizard, brown with yellow markings.

Delma fraseri (W. A.), green, with black and white bands, very long tail.

D. impar (V.), green, with light lines along the sides. Pletholax gracilis (W. A.)

Gonyocephalus spinipes (N. Q.), brown with dark spots and white lines on the limbs.

G. godefroyi (N. Q.), brown with yellow bands.

G. boydii (C. Q.), brown with dark bands on body and tail, yellow throat and belly.

Amplibolurus maculatus (W. A.), grey with white bands on the sides, and black spots; black lines on the throat and chest.

A. imbricatus (S. A.), yellow with black and white spots, brown and white bars on the tail.

A. ornatus (W. A.), black with yellow spots, and yellow bars on tail and limbs.

A. cristatus (W. A.), dark green with black chest and limbs.

A. caudicinctus (N. W. A.), pale brown with black rings round tail.

A. decresii (S. A.), olive brown with black chest.

A. pictus (S. A.), brown with light spots.

A. reticulatus (W. A.), yellow with black spots, and black rings on the tail.

A. adelaidensis (S. A.), greenish grey, with brown and white spots and dark bars on the tail and limbs.

Agamide.

Agamis pulcherrimus (W. A.), grey with four rows of black spots. 
A. paltidus (W. A.)

A. angulifer (Tas.), brown with broad black band.

A. muricatus (Tas, and N. S. W.), brown with dark spots.

A. barbatus, brown with black spots on neck and black throat.

Tympanocryptis lineata (S. A.), brown with five light lines and dark bars on tail.

T. cephalus (N. S. W.), brown with dark bars on body and tail.

Diporophora bilineata (N. A.), reddish with dark spots or light bands.

D. australis (N. A.), brown with dark spots.

D. bennettii (N. W. coast), greenish brown with bands on tail and limbs.

Physignathus gilberti (N. coast), green with light bands on sides.

P. longirostris (N. S. W.), light bands on the dark back.

$P$. temporalis, brown with dark cross bands.

\section{SKINKS.}

Egernia luctuosa, yellow with black spots and bands.

E. whitii (N. S. W. and Tas.), brown with black bands and spotted with yellow.

E. dorsatis (Q.)

E. major (N. Q.), brown with black streaks and spots.

E. striolata (Q.), brown with longitudinal black streaks.

E. kingii (W. A.), black with yellow spots.

E. cunninghami, dark brown with black bands.

E. stokesii (W. A.), brown with pale spots.

E. depressa (W. A.)

Titiqua nigrolutea (S. A. and Tas.)

T. occipitalis (S. A.), yellow with dark bands.

T. adelaidensis (S. A.), pale grey with reddish limbs and tail. 
Hemisphariodon gerrardii (Q.), yellow with eight dark cross bands.

Lygosoma lesueurii (W. A. and N. coast), olive with handsome black and white markings.

L. leae (S. A.) brown with six white longitudinal lines.

L. tceniolatum (N. S. W. and N. coast), yellow with black bands and white streaks.

L. fischeri (N. W. coast).

L. strauchii (Q.), only half the size of the rest, brown with white spots and streaks.

L. labillardierii (W. A.), olive with white spots.

L. quoyi, olive with black spots, white spots on the sides, yellow line along the back.

L. tenue (N. S. W.), light brown with a network of black markings.

L. murrayi (Q.), brown above, black along the sides with yellow spots.

L. pallidum (N. S. W.)

L. isolepis (W. A.), brown with darker spots and white dots.

L. elegantulum (C. Y.)

L. richardsonii (W. A.), light brown with darker bands.

L. fasciolatum (Q.)

L. monotropis (N. S. W.)

L. mustelinum (S. A. and N. S. W.), yellowish with brown lines and dots.

L. challengeri (Q.), dark brown with black and yellow spots.

L. entrecastauxii (Tas.), green with three black bands.

L. ocellatum (Tas.)

L. pretiosum (Tas.)

L. trilineatum (Tas. and N. S. W.), olive with black band.

L. metallicum (Tas.), olive with brown spots.

L. guichenoti (S. A.), bronze green with spots. 
L. fuscum (N. Q.) brown with a black lateral band.

L. rhomboidale (Q.), brown with black bands, blue throat and lips.

L. peronii (Q.), common in the islands of Keppel Bay, olive with light dots and lateral lines.

L. pectorale (Q.), grey with red stripe, red chest and sides, head pale green with black spots, pale blue throat.

L. mundum (N. Q.), olive with dark spots, blue throat.

L. atrocostatum.

L. albofasciolatum (N. coast), brown with pale cross bars.

L. rufescens (C. Y.)

L. branchiale (N. S. W.), brown with six large black marks on the neck.

L. casuarince (N. S. W. and Tas.)

L. australe (S. A.), pale brown with black spots.

L. punctulatum (Q.)

L. crassicauda (N. Q.)

L. pumitum (C. Y.), yellowișh with rows of brown dots.

L. peronii (W. A.)

L. decresiense (S. A.)

L. quadritineatum (W. A.), light brown with black dots.

L. scutirostrum (Q.)

L. aquale (N. S. W.)

L. microtis (W. A.), grey with black bands on the sides.

L. bougainvillei (S. A.), grey with black dots and lines.

L. fragile (Q.), olive with black lines.

L. gerrardii (W. A.), yellow with three dark bands.

L. punctatovittatum (Q. and V.)

L. lineopunctulatum (W. A.), grey with brown spots.

L. miopus (N. S. W.), pale green with four rows of black dots.

L. bipes (N. S. W.), reddish with dark spots and bands.

L. propeditum (W. A.), light brown with two rows of dark spots. 
L. reticulatum (N. S. W.), brown with two dark cross bands, white sides and belly.

L. verreauxii (Q. and N. S. W.)

L. truncatum (Q.), grey with rows of dark spots.

L. ophioscincus (Q.), light brown with black tail.

Ablepharus lineo-ocellatus, brown with black spots and white streaks.

A. taniopleurus (N. Q.), green with white streaks.

A. greyi (W. A.)

A. elegans (W. A.), light brown with black, white-edged, lateral band.

A. muelleri (W. A.), bright green with dark lateral bands.

A. lineatus (W. A.), silvery grey with brown stripes.

Ophiopsiseps nasutus, grey with black spots. 


\section{PART III.-CROCODILES}

\section{CROCODILES}

Is the northern rivers of Queensland, from the Fitzroy upwards, are huge crocodiles, misnamed "alligators." From the decks of coasting steamers which lie in these estuaries taking in wool and meat and gold, passengers see the large water-lizard (Physignathus) aforementioned and vow in all good faith that they have set eyes on a young crocodile. I made the mistake myself on two occasions, but was fortunately able to correct it by comparison with the genuine article.

On close inspection, the crocodiles are easily distinguished from lizards by the bony protuberances imbedded in the back. The tongue, which is so short as to be mostly invisible, is incapable of being thrust out; the teeth, on the other hand, are generally in evidence, as there are no lips to hide them.

Terribly armed, however, as are the long jaws, the powerful, flattened tail, which largely assists the webbed hind-feet in their rapid swimming, is a still more formidable weapon. And although, like the turtles, these creatures are at their best in the water, their movements 
on shore are at times unpleasantly quick, as the three long claws on each forefoot get a good purchase in the soft earth of the banks, into which, unimpeded by any web inembrane, they dig deeply.

The eye, which is small and of a light green colour, is protected by three lids. These animals are oviparous, depositing in the mud eggs not unlike those of birds, only with a higher degree of polish on the shell.

It is interesting to note that the strong musky odour secreted in the glands below the throat, and noticeable long after the specimen has been dried and mounted, has been considered by some a lure for the fish on which these creatures feed largely.

There are at least two species, Crocodilus porosus and $C$.johnstonii, the latter with a beak almost as long and slender as that of the gavial. 


\section{PART IV.-TORTOISES AND TURTLES}

\section{TORTOISES AND TURTLES}

The seas and rivers of Australia have several Chelonians. There are river and land tortoises, but all the turtles are aquatic, the marine species being migratory at the breeding season.

The River Tortoise (Chelodina longicollis) of the Murray has a snake-like, flexible neck and pointed head. It is very active in the water and feeds on fish, the species being remarkable, even among a long-lived family, for tenacity of life. The lower shell is of a bright yellow.

On the north coast are C. expansa (Q.) and $C$. oblonga, allied species.

Chetemys and Elseya are also river-turtles, and there are besides these Chelonia squamala, C. midas, C. imbricata and $C$. caouana (Thalassochelys), or the Loggerhead.

And last, Sphargis coriacea, or the Leathery Sea-turtle, a couple of which we brought back from Thursday Island in our long boat. The shell was not harder than a new saddle; the jaws were very powerful and terminated in a hooked beak; and the feet were like paddles and apparently without claws or toes. 
BATRACHIANS 



\section{BATRACHIANS}

After the reptiles, and directly between them and the fish, come these amphibians, solely, so far as Australia is concerned, Frogs and Toads. It is a common error to include them with the reptiles, from which their early metamorphoses, as well as the absence of scales ${ }^{1}$ and certain anatomical peculiarities, into which it is here unnecessary to enter, distinguish them.

Tree-Frogs (Hylidce) form the bulk of Australian frogs, but Swamp-Frogs are also fairly abundant. Of the typical genus Rana there is but one, $R$. papua.

Toads are both varied and numerous, but the typical genus Bufo is wanting.

The Tree-Frogs are perhaps the most remarkable and interesting of all. These beautiful little creatures are most agile among the branches, and so light as to run over the larger leaves, the moisture of which they are able to absorb by a remarkable arrangement of pores along the abdomen.

They are purely insectivorous, the tongue, forked in some species, being furnished with a gummy secretion. The small teeth are, as in most frogs, in the upper jaw

1 Some extinct batrachians were scaly. 
only. The males of some species utter a kind of song at nights. The eggs of these tree-frogs are, like those of the rest, deposited in the water. Of characteristic species there are :-

Rana papua, the only Rana in the continent, and confined to the Cape York peninsula. The male has internal vocal sacs.

Hyla carulea of the north coast, a green tree-frog only about three inches in length, with webbed toes. Some curious glands occur at the back of the head. Krefft is of opinion that it varies its insect diet with small mammals and birds.

H. aurea is another tree-frog, to be seen, like the last, at Regent's Park. It is a favourite dish with the aboriginals, who catch it by torchlight.

Notaden bennettii is a large Queensland toad, the colour being light green with a black cross on the back, and black spots on the white throat.

The most common West Australian swamp-frog is the Striped Swamp-Frog (Limnodynastes dorsalis), and it is confined to that colony

\section{Australian Batrachians.}

Rana papra (C. Y.)

Notaden bennettii (Q.)

Myobatrachus gouldi (W. A.)

Mixophyes fasciolatus (N. S. W.)

Limnodynastes dorsatis (W. A.)

L. peronii (Tas. and N. S. W.)

L. platycephalus (S. A.)

L. tasmaniensis (Q. and Tas.)

L. ornatus (N. coast).

L. sa'minii (N. S. W.) 
IIyperolia marmorata (N. S. W.)

Chiroleptes platycephalus.

C. australis.

C. inermis (Q.)

C. brevipes (Q.)

C. brevipalmatus (Q.)

Pseudophryne australis (W. A.)

P. guentheri (W. A.)

P. bibronii (Q. and V.)

P. coriacea (N. S. W.)

Crinia signifera.

C. georgiana.

C. affinis.

C. lcevis (Tas.)

C. tasmaniensis (Tas.)

IIyla freycineti (N. S. W.)

H. nasuta (N. coast), brown with dark bands.

H. dimolops (N. S. W.)

H. krefftii (N. S. W.)

H. parvidens (V.)

H. adelaidensis (W. A.), brown with white streaks and spots.

H. citropus (N. S. W.)

H. latopalmata (Q.), purple with black streaks.

H. cyclorhynchus (W. A.)

H. lesueurii (Q. and N. S. W.), olive with black streaks and white spots.

H. affinis (N. coast), brown with black and white markings. H. nigrofrenata (C. Y.), light brown with black bands and spots.

II. caruler (N. coast), light blue and white belly.

II. aurea, blue with brown spots and white bands.

H. phyllochroa (E. coast), bluish with purple shades on the side and a black line on the head. 
H. gracilenta (E. coast), bluish with white lines.

H. jervisiensis, light grey.

II. peronii (Q., N. S. W. and Tas.), brown with yellow markings.

H. rubella (N. coast), reddish with dark spots.

II. dentata (E. coast), brown with dark spots.

H. ewingii (Tas.), brown with dark spots and white streaks. 


\section{FISHES}

0.2 



\section{INTRODUCTORY}

To the student of Fish, Australian seas present a galaxy of interesting families. Indeed, the sea-fish absorb most of one's attention, as the rivers only furnish a couple of fish of either great commercial value or scientific interest, respectively the Murray Cod of the south and the Ceratodus of Queensland.

The most striking characters of Australian sea-fish are their rainbow hues, projecting teeth, and a tendency to throw out spinous growths that make their safe handling a matter of some difficulty.

For table purposes, they are a long way behind the products of colder seas, and a number of our most important families are either wanting, or, if present, systematically neglected.

The $\operatorname{Cod}^{1}$ family, for instance (Gadida), which delight in the cool waters round Newfoundland and the Lofoden and Faroë isles, love not these Australian seas, and are only represented by the insignificant "Ling" or "Beardie" (Lotella). The "Whitings," as they are called, are not

1 The so-called Murray Cod (Oligorus) and Black Rock-Cod (Serramus) are perches; and the Red Rock-Cod (Scorpana) is a seascorpion. 
Gadida, but (Sillago) either related to our weevers, or $($ Odax) members of the wrasse family.

The Herrings (Clupeidce) are of the families above alluded to, which are present in those waters but neglected from want of capital or enterprise, or both. There are no proper drift-nets, and so the Clupea sugax ${ }^{1}$ and $C$. sundaica perform their inshore migrations unnoticed, and colonials profit not by the rich harvest at their city gates.

The so-called "Fresh Water Herrings" or "Sardines" (Chatossus), of which there are Chatossus richardsonii and the more northern $C$. erebi, have nothing in common with the Clupeidce.

Tenison-Woods points out that they are, like eels, forbidden as food to the young native women.

The Salmon is not indigenous in those waters, and hitherto all attempts to introduce it have signally failed. though Mr. Savile Kent and others have succeeded beyond expectation with the Trout, which grows in Tasmania to a weight of nearly thirty pounds, beside which giants even Father Thames can turn out only speckled minnows. The Sewin also does well in that colony. But the salmon sturdily refuses to be acclimatised; and one reason for its objection, a reason that equally applies to those French rivers that debouch on the Mediterranean, is that the temperature of the sea at the mouth of the rivers is fully $10^{\circ}$ higher than in the estuaries of European and American salmon rivers.

The so-called "Salmon" of Sydney (Arripis salar) is no member of the family, and does not resemble the true

${ }^{1}$ Mr. Cohen (Marine Fish and Fisheries of New South Wales) mentions one case in which bushels of the Pilchard (C. sayax) were netted in Hobson's Bay ; and Mr. Lindsay Thompson (History of the Fisheries of New South Wales) of an immense shoal appearing off Otago (N.Z.), chased by porpoises and mutton-birds. 
salmon in any particular. In the estuary of the Fitzroy river (Queensland), I caught fish locally known as "salmon" far gamer than the Sydney fraud, and also much better eating.

The Flat Fish (Pleuronectid $x$ ) are either very poorly represented in these seas, or else, owing to the want of trawling gear (and the rocks would soon put it hors de combat, even if introduced), insufficiently appreciated. So far, we have only a tailless freshwater Sole (Synciptura), a Flounder, both reaching the market irregularly, and a few still rarer kinds, including a recently discovered species, something like a halibut, from the Queensland coast.

Thus, Australian seas would appear, as indeed they are, but poorly supplied with many of the fish which we most esteem as food.

On the other hand, they yield a few species, not known in our seas, which cannot, when properly cooked, be improved upon.

Such, for instance, are the great Schnapper (Pagrus), a red-bream, of which more anon; the delicate SandWhiting (Sillago), a relation of the hideous and obnoxious weever; the large-eyed, crimson Nannygai (Beryx), taken on the Schnapper grounds; the real Trumpeter (Latris) of Hobart; the Queensland Giant Perch (Oligorus) (called, like any other large fish in those parts, by the aboriginal name "Barramunda"), and one or two more.

Many of these Australian fish, then, are excellent eating, but not quite so large a proportion as some writers would have us believe. I speak from actual experience, having caught and eaten most of the market kinds.

Mr. Cohen, ${ }^{1}$ for instance, seems omnivorous where fish are concerned. Up to a certain point, I recognise the excellence of his enthusiasm, because the neglect of the

1 The Marine Fish and Fisheries of New South Wales. 
Australian fisheries is a lamentable pity, and anything tending to arouse a proper interest in the subject and divert capital and enterprise into this new channel is deserving of praise. Only I must with regret decline to follow Mr. Cohen when he asserts that the Sydney Blackfish (Girella) is by no means ill-flavoured, or the Wirrah (Plectropoma) " not of bad flavour if properly cooked." And speaking of the insipid "salmon," he says: "It is more than surprising that such immense bodies of edible fish should be suffered to pass by our very doors unheeded and untouched." A lament which none will echo that have ever tasted cod, sole, or dory, and few indeed that have not; and with so many excellent fish in their seas, Australians may well be excused if they decline to share this gentleman's admiration for blackfish, wirrah and "salmon."

He seems indeed further to labour under the erroneous impression that fish too coarse for consumption when fresh may be profitably tinned for export, as, for example, the King and Samson fishes (Seriola).

But the cheapness and excellence of European table fish are too well known for many to embark in so hopeless a project as supplying inferior kinds from the antipodes.

For purposes of sport, many of these Australian fish are admirable; and I propose, before giving a systematic table of the chief fish families, to include such a short sketch of the fishing as may be of service to anglers going out there. 


\section{PART I.-ANGLING}

\section{ANGLING}

THE favourite sport, bar racing, in the Australian capitals is unquestionably angling. I use the word in its broadest sense of fishing for amusement, and not in the more modern and restricted meaning, capturing fish with the rod. For rods are comparatively little used in New South Wales, where sea-fishing is, so far at all events as Sydney anglers are concerned, the only kind available.

In the streams of Victoria and Tasmania, as in New Zealand, the fly rod is in great request, but the two eastern colonies of Australia know not the trout.

The Australians resemble in this their predecessors in the land; they are very skilful fishermen. All the arts of fine tackle and ground-baiting they know in their entirety; all the lore of wind and tide they study with infinite patience; and the skill employed by the "outside men," "groper-men," "black-brimmers," and others in catching their favourite fish, is such as to astonish even those who have made some study of fish and fishermen all the world over.

Nor has their enthusiasm its equal in any other 
country; for the bilious will venture times and again out on to the heaving bosom of the deep Pacific, and the nervous do not hesitate, in the pursuit of the somewhat mythical groper, to slide down the face of escarpments the bare memory of which makes me shudder.

Of the aboriginal fisheries, their cunning stone dams or the unerring spear, sometimes tipped with bait, I give no

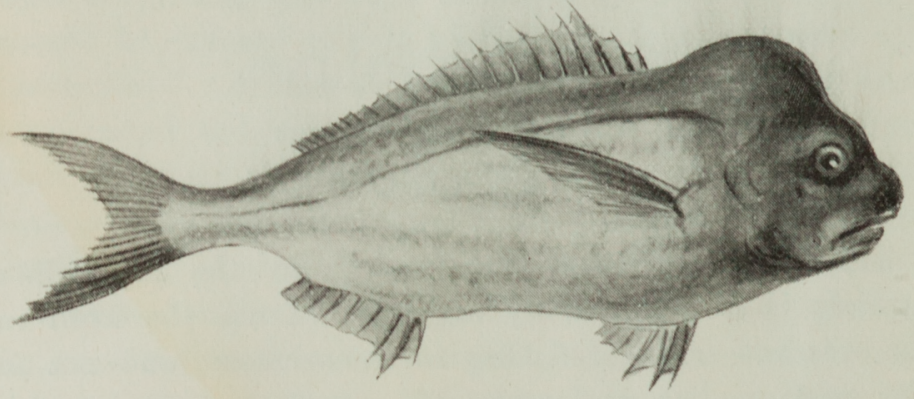

SCHNAPPER.

account, my object being to describe the sea-fishing, of which I saw a good deal during my visit.

The Schnapper Outing is perhaps one of the most characteristic leaves from one's colonial angling diary, and I will take it first.

The Schnapper, or Snapper, is a handsome red-bream (see Part III.) that moves up and down the coast, frequenting more particularly those parallel reefs that prevent any hope of the establishment of a trawling industry.

This beautiful fish was formerly captured in great numbers within the heads that guard the entrance to Port Jackson, and the largest preserved specimen I ever saw had been taken in Middle Harbour. All this, however, is changed, and it is necessary, nowadays, to seek the schnapper out in the open ocean, some of the favourite grounds 
being fifty miles up the coast. Parties consequently charter a steam-tug and start overnight, reaching the Schnapper rocks at daybreak, the best time for fishing. The expense of the tug is thus shared by a number, and there are several Schnapper clubs, as they are called; in Sydney, the largest being the "Amateur Fishermen's Society of New South Wales," the members of which, however pursue other fish of all kinds. I had the pleasure of delivering a lecture on English sea-fishing to an audience of some three hundred of them and their friends, and they showed great interest in the methods practised "at-home," as they call it, even those whose parents were born out there.

The shorter schnapper-outings, in which one leaves the harbour at ten in the morning and returns about eight the same evening, are more convenient for the majority, although the takes are small as a rule, both by reason of the paucity of fish on the exhausted grounds near Sydney and the fact that one misses the best fishing-time, the early hours of dawn.

The members of such a club assemble, then, at ten sharp, looking very business-like in leather gaiters and hats of every shape and hue. I do not know what the gaiters are for. I dispensed with them myself, and got on very well without them. In river-fishing in those parts they are highly desirable as safeguards against the black snakes generally found near water. But on a steamer, I fail to see the object.

The boat heads down the harbour, and as soon as Fort Denison (alias "Pinchgut") is left behind, all who are using new lines let sixty or eighty yards out over the stern to stretch and take the kinks out.

A properly stretched line should run as straight as a wire. And now as the gentle swell announces that the 
Heads are at hand, the hand-bags are opened and the simple tackle is made up on the spot, a large schnapperhook on $6 \mathrm{in}$. of fine snooding being fastened two feet above the end, which is then made fast to a $2 \mathrm{lb}$. lead.

A second hook is sometimes added close to the lead, but with more zeal than wisdom, as it is very apt to catch in the uneven, rocky bottom.

The bait, consisting of pieces of squid, mackerel, yellow tail, mullet, and other fish, is generally cut up and dealt out on the way out; and so keen is the friendly competition on such occasions, that, as soon as the members of the party have drawn for their places along the gunwale, they bait their solitary hook and stand ready for the cast at the signal from the whistle.

If he knows his business, and there is no mist about from bush-fires, the man on the bridge picks up his marks without difficulty, steam is shut off, the boat is brought into position to drift southward over the reef, and at the first blast of the whistle out fly the leads and go shearing away at a good angle, the fore-finger being protected against the cutting line by a sheath of leather or indiarubber.

The moment is an exciting one, for there is as a rule no tedious waiting for the fish, but, if we are well over the rocks, an immediate call to arms, vigorous bites, the responsive stroke of a foot or so of line pulled smartly in over the gunwale, and a long, strong pull.

Mr. Cohen, already quoted, says the veriest tyro can strike the schnapper. Well, I have not been exactly a tyro at sea-fishing for a good many years now, but it took a couple of outings to show me that the exact moment for striking was on the second of the two short snaps that invariably prelude the frantic downward rush.

It is sheer hard work, this hauling of sixty or eighty yards of wet line attached to a $21 \mathrm{~b}$. lead, and maybe a $101 \mathrm{~b}$. 
schnapper. As much of the weight as possible is thrown on the gunwale, but even then the exertion is great, for the strain on the line must not be relaxed for a second, otherwise the schnapper will get its shoulder to the line and vanish in a trice.

The only other fish I found bite in any way like the schnapper was the Morwong, a relative of that muchesteemed fish the Tasmanian Trumpeter. I soon got to

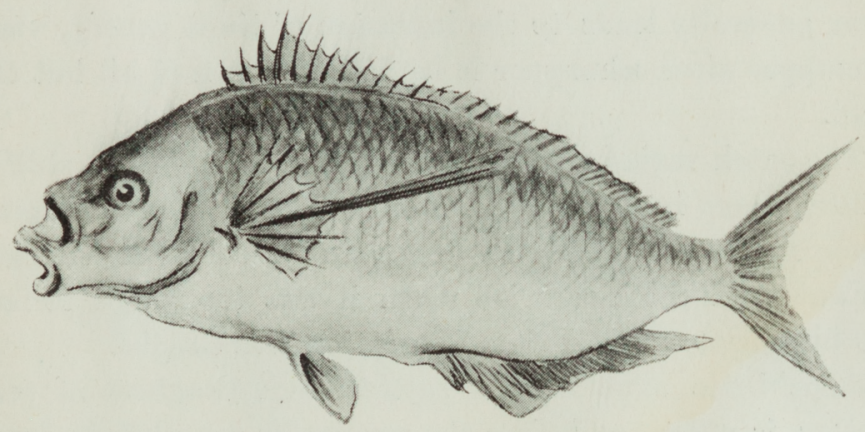

MoRWONG.

know the different bites of the other inhabitants of the schnapper-ground, the little Sweep, which is the only edible member of the Coral Fishes (Chotodontidce), and which soon changes its silvery hue after death for a garb of sooty blackness; the Nannygai, which is supposed to feed at the same time as the big schnapper, and is, therefore, always welcome; the Leather Jacket, which is the reverse; the Pig-Fish, the Sergeant-Baker, Traglin and Sea-Pike, and, last, the ugly Flathead, whose advent tells that the boat has drifted off the rocks, and is consequently the signal for "All lines aboard!" and a shift.

And occasionally there is a lively stampede below us as the tug becomes the centre of an admiring school of sharks, 
nurses, and blue-pointers, which ruin amuck through the lines until, as sometimes happens, hauled aboard. A female, as often as not, with her noxious brood almost ready for birth. Well, they make excellent bait. Occasionally, the sharks prove just a little too much for sport, so coal is piled on and we steam at full speed for a further ground. The great precaution against attracting these pests is to forbid the men to throw any fish overboard after cleaning the bait, as their commendable zeal in keeping their decks clear generally leads to the intrusion of these gentry, when schnapper after schnapper is hauled up shorn of all but the head.

The catch varies greatly or different days. With skilful fishers, sharp hooks, and fresh bait, I have seen the decks disappear rapidly beneath the rainbow-coloured victims. On one memorable occasion when it was too rough to feel the bites, not a fish of any description was caught.

Some little experience, surest though roughest of preceptors, is necessary before the newcomer can abstain from handling those prickly fish. And dead or alive, they resent liberties, the wounds inflicted by the spines of the Fortescue, Flathead, and some others being exceedingly severe. An onion, found by experience to allay immediate pain, is generally included in the basket.

Taken all round, the successful schnapper-outing ranks among the most pleasant and varied of one's red-letter angling days. The Australian coast has a rugged grandeur of its own, and the visitor will find additional interest in the whales spouting at no great distance and the great molly-hawks soaring almost within stone's-throw.

I now come to the quieter angling within the Heads amid surroundings which, though lacking the freedom of the boundless ocean, are unquestionably picturesque of their kind. 
Very fine tackle, fresh prawns, and an artfully compounded "berley" are the etceterc of this sport, and the fish are Black Bream, Flathead, and Jew fish.

The "berley" is a pungent groundbait composed of bran, condemned tinned salmon, salt herrings, and cheese. The attractions of a conglomeration of these ingredients, as carefully blended as those of a Madras curry, need no eulogy. They will be readily imagined.

The bream-fisher will sit up overnight making this

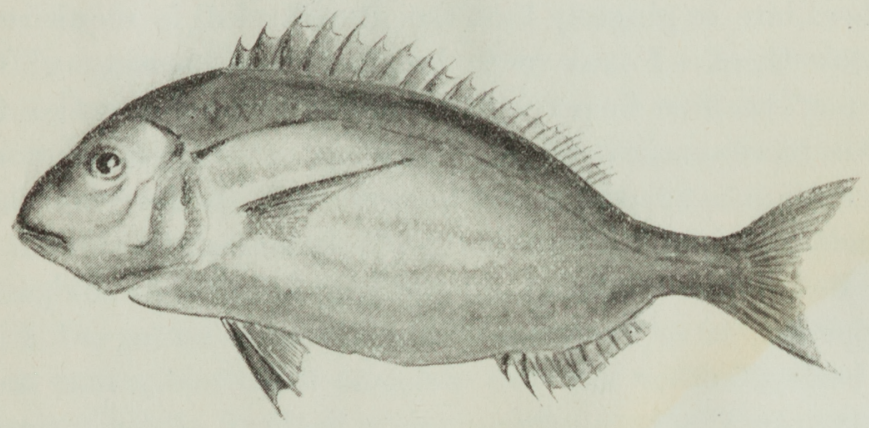

Black Bream.

terrible compound, and early next morning his little boat is moored off some rocky headland in the Hawkesbury, or in some small creek down the coast. The silence would be oppressive, but for the gamut run in friendly rivalry by a couple of giant-kingfishers perched in the tee-trees hard by. A little of the "berley" is first cast over the side, and from the rate and direction of its descent the angler learns all that is necessary about the strength and lay of the tide.

The favourite line is then produced, consisting of a very fine silk twist wound on a cork and terminating in a small hook on gut, on which is pinched a fragment of sheet-lead. The lead serves a double purpose, for besides sinking the 
line, it forms the nucleus of a ball of "berley" which, disintegrated by the action of the water, presently falls in an alluring shower about the prawn that hides the hook. The line is sometimes tapped or twitched to ensure this effect. As a rule, the bigger " black brim" (they are silvery by the way, but the epithet serves to distinguish them from the red brim, as the young of the schnapper are called) do not bite in earnest until near sundown. More often still, save on the hottest summer evenings, I believe they do not bite in earnest at all. And the veterans of the shoal bite so gingerly that the utmost skill is requisite to hook them. I have even heard that enthusiasts rub the top of the first finger with pumice in order to make the skin more sensitive to the shy biting. Whatever they do, the result is surprising. I have missed fish after fish while some colonial friend has brought a dozen or twó aboard.

Besides the black bream, and long before its slumbering appetites have been roused by an extra strong whiff of "berley," other and less welcome fish usually find their way into the boat - the ungainly flathead aforementioned and frisky little yellowtail, the latter making excellent bait for any large jewfish that may be prowling in the neighbourhood. Coarse fish are these rapacious jews and nearly allied to the maigre of European seas. Viewed in the rapidly-changing hues that precede death, there is a certain beauty in the jewfish; but on the fishmonger's slab it looks even worse than our hake, to which it bears some slight resemblance.

The peaceful silence of those Australian creeks, with all the novelties of bird-life, the bright little geckoes and treefrogs dashing among the undying leaves, and the warlike ants ever busy and watchful in the sand, has a strange fascination for any one out from the old country. It is all so different. No land is so fresh and green, as I recollect 
Mr. Alfred R. Wallace once saying to me, as our own; but few others have surely so poor a fauna. So the Australian waterside is sure to interest the new-comer.

There are other scenes amid which the angler casts his hook upon the waters. Whiting fishing in the Brisbane river, for instance, has something of novelty in it, for it is necessary to don top-boots and wade out over the hard sand flats to meet the rising tide and to use a light rod and line with some deftness, casting the prawn bait right into the midst of the grayling-like fish that can be plainly seen as they work up the sandy channels.

The top-boots by all means. They are of more use here than aboard the schnapper boat, for in the sand lurk great stingrays with whip-like tail and sharp dagger and hideous eyes looking eagerly up for unwary passers-by.

Then there is that perilous amusement, the rock-fishing along the iron-bound coast of New South Wales. Armed with the correct tackle for blue-groper, the heavy handline to wit, and at least a score of spare hooks, the enthusiast glides gaily down precipitous tracks that would make a chamois turn back, leaps from ledge to ledge with a sangfroid that should excite the envy of the longimanous gibbon, crawls like a snake along ledges less than a yard in width, a precipitous wall on one side and on the other a fall of a hundred feet into the water, with more chance of sharks than rescue.

Familiarity breeds contempt; and I have seen Sydney youths trip to and from these fishing-grounds with no more care than they would up Pitt Street. But, for myself, I only once swung the ponderous groper-line, only once tried the cungevoi, a molluse in much esteem for bait, and soft-crab. Once was enough. Accidents occur now and again, and you may find that the ledge you are fishing from has acquired a flavour of historic association 
from some such local names as "Brown's Fall" or "Smith's Mistake"!

Not only groper are caught in such places. Indeed, groper seem rare nowadays. The flabby wirrah, a thing of dreadful teeth, the sweep, and traglin also come swinging up the rocks. And at times these hardy rock-fishers can catch nothing better than toad-fish-poisonous little wretches that puff themselves out like bladders and show an extraordinary reluctance to die. Their tenacity of life is proverbial on their native shores, and one writer mentions having flung one back in the water which he had partly dissected to recover his hook, when the still lively though disembowelled "toad" made at once for the hook, and was caught anew. ${ }^{1}$

"Salmon-fishing" is another sport dear to some pothunters, who walk along the sandy beaches at Coogee or Bondi and foul hook the wretched fish called "salmon," which work up the coast in immense shoals just behind the broken water. A leaded line, with a dozen bare hooks, is cast over the shoal and dragged smartly through their midst.

Into the subject of beach-fishing I shall not enter. Having come into the world as a man and not a gum-tree, I declined to plant myself by the hour in the sand with no other apparent object than catching small sharks. I would rather bring these angling remarks to a close with a word or two on one last memory of colonial sport with the rod, the capture of the Giant Perch (Oligorus) of the Fitzroy. In comparing the fish of the southern waters of that continent with their congeners off the coast of tropical Queensland, it will invariably be found that the

1 Tenacity of life is characteristic of many Australian fish. The catfish are remarkable in this respect; and Lumholtz declares that the Queensland blackfish can exist nine hours out of water. 
latter have a tendency to assume the maximum proportions vouchsafed to their race. I never saw very large hammerhead and carpet sharks and sawfish until I had coasted among those peaceful but treacherous coral seas. The schnapper is not there; he loves the cooler waters of the south.

But the perches, more especially, and herrings run to gigantic dimensions, and of such is the Fitzroy perch, allied to the "palmer" of the Mackay, and known locally as the "barramunda," a name that more properly belongs to the Ceratodus, or Lung Fish.

Like the Corvina, Silurus, Maigres, Pogonia, and son:e Horse-mackerels (Carangida) and Gurnards (Triglida), this great perch grunts under water, and the angler listens eagerly for this sound beneath some quiet pier as the sun sinks behind the low mangroves.

One wharf I recollect well at the now deserted Port Alma, on an arm of Keppel Bay, where of an evening there was as good a chance as anywhere of a "barramunda." The tackle was primitive, and consisted of a stout rod or pole, to the end of which was fastened a $6 \mathrm{ft}$. length of stout cord and a large double hook, to which was lashed a piece of white parchment or, better still, a fresh-killed "Skipjack," 1 as they call the young mullet that skip along the surface. This bait is attached head downwards. The Dorab (Chirocentrus) is another favourite bait for these perches. Treading cautiously along the creaking planks, the angler places himself as nearly as possible over the spot whence the grunting sound proceeds, and, standing well back out of sight, drops his hook with a splash on the ebbing water, which carries it under the

1 This name is also applied to the remarkable Fitzroy Irudhopper (Periophthalmus) which leaps out on the wet sand and climbs the mangrove trunks; and, at Melbourne, to the Tailor. 
platform on which he stands. This "dapping" continues da capo until a louder grunt announces a rush, and the rest depends on luck and physical strength. Skill is at a discount. It is merely a question of holding on until the great perch is sufliciently exhausted to be cajoled round to the steps, where a friend, holding fast to the railing, should be in readiness to slip his other hand under the gills and lift it out.

Here, too, are many catfish, and also the local "salmon," a fish between a mullet and a bass in appearance, and excellent eating. ${ }^{1}$

Those desiring fuller information on the sea-fishing of New South Wales than I have had space for should consult an excellent little brochure, recently published by Mr. Thackeray of Sydney, and entitled The Amateur Fisherman's Guide. For the fish and fisheries, reference should be made to the works of the Rev. J. E. Tenison Woods, J. W. Ogilby, Lindsay Thomson, and Philip Cohen, for New South Wales; Castelnau, for Victoria; and Savile Kent's Great Barrier Reef, for Queensland.

1 The Cooktown salmon is a curious fish (Polynemus) with stringlike processes beneath the head. It belongs to the "Tassel Fish," one species of which is nearly blind. 


\section{PART II.-FRESH-WATER FISH}

\section{FRESH-WATER FISH}

IMPORTANT as they may be in forming an estimate of the specialised fauna of Australian waters, the river fish of that region are, as at present known, of so little importance, like many of the rivers themselves, that I shall depart from the rule bitherto observed in these pages, and give a somewhat lengthy account of the sea fish, even those which are not peculiarly Australian.

The reasons for the subordinate interest that attaches to the river fish are three in number. In the first place, the great cities all lie on the coast, and the nature of the interior precludes the possibility, one may safely say, of populous centres rising up far from the sea. In the second, large rivers rich in fish are somewhat few and far between. And lastly, with one or two exceptions, the fresh-water fish of that region are such as commend themselves neither to the sportsman nor the epicure.

An exception is found in the Murray Cod (Otigorus macquariensis), a fish of considerable importance, great size, and splendid eating. This perch, for it is to that family that it belongs, is taken of the weight of $100 \mathrm{lbs}$.; 
and in such esteem is it in the cities, that the yearly supply drawn from the Murray alone is computed at the enormous weight of $100,000 \mathrm{lbs}$.

The fish is allied to the River-groper of Queensland and to the marine Hapuku of New Zealand. There is an allied species (O. mitchallii) in the southern rivers, called, by way of distinction, the Murray Perch.

These fish are caught chiefly on night-lines.

The aforementioned Giant Perch (Otigorus gigas) of the Fitzroy, the "Palmer" of the Mackay, is one of the finest of these perches. Its peculiarity of grunting under water has already been remarked. As also the fact that it is misnamed " barramunda," a title that belongs by rights to the Queensland Cerutodus.

Among other river-perches, mention must be made of Dutes hasuelli, a Brisbano River species, and of the Silver Perch (Therapon richardsonii), a valuable food species taken with the sieve net in the Murray and Murrumbidgee. It never takes the hook.

The river Black Fish ${ }^{1}$ (Gadopsis marmoratus) is a good eating fish, though somewhat rich, the average market weight being a pound. It is found in the southern streams of the continent and in the northern waters, the Anson among others, of Tasmania.

A gainst the Catfish (Copidoglanus) there exists a good deal of prejudice, which I am at no loss to understand if it is identical with the species I used to catch in the Queensland rivers. On principle, I tasted this once. Still, opinions differ; and at one angling meeting in Sydney I recollect listening with admiration to a candid orator who avowed his preference for it, putting it before schnapper and black bream.

The Fresh-water Herrings (Chatoessus), or Sardines, are,

1 Quite distinct from the Blackfish (Girella) of Sydney. 
like the last, absent from Tasmania. There are $C$. richardsonii, or the Bony Bream, of the Darling, and $C$. erebi of Western Australia.

The so-called "Grayling," or "Cucumber Mullet" (Prototroctes), of North Tasmania, more particularly the Forth and Mersey rivers, occurs on the mainland only in a few streams in the south of Victoria, as the Yarra and Glenelg. Formerly abundant in the southern rivers of Tasmania, it is now found only in the north of that colony, and I believe that failure has for the most part attended the Government's efforts to restore it to its old haunts.

This fish rises well to the artificial fly, and from its adipose fin it was originally, though wrongly, classed among the Salmonida, of which the only indigenous member is, I believe, the little Retropinna.

Tenison Woods puts the average weight at $11 \mathrm{~b}$., but I think $\frac{1}{2} l b$. would be nearer the mark.

The Mountain Trouts (Galaxias) of the southern waters of Victoria and New South Wales and the whole of Tasmania are allied to the burrowing Neochanna of New Zealand, and include G. delicatulus, G. ocellatus, $G$. attenuatus, and many others. The air-bladder of these little fish is proportionately large.

But of greatest interest to the scientific world, excepting perhaps the Port Jackson Shark (Cestracion) - and at all events of river-fish - is the group of Lung Fishes, called "Dipmoi" or double-breathers, owing to the fact that they possess well-developed lungs and gills. They are represented in Australian (Q.) rivers by Ceratodus forsteri, which has relations (Protoptesus, with two lungs) in Africa, and in the Amazons of South America (Lepidosiren). They are of the ganoids, a once powerful but now dwindling race.

The Ceratodus, or Lung Fish, is now caught in only two Queensland rivers, the Mary and Burnett, at Christmas- 
time, and especially in the deeper holes in the latter river near a place called Gaynda.

The colonials call it "salmon." Its natural food seems to consist of aquatic plants, and it may be taken with a hook baited with a tuft of these.

When hooked, it struggles violently, spouting air through its nostrils like a whale. It is a dark green fish with red markings.

Lumholtz asserts that it creeps ashore; but this is hard to believe, as when placed on the bank it shows little power or inclination to move, and indeed, for all its lung-breathing, soon dies out of water.

Its blood circulation is, roughly speaking, intermediate between that of frogs and fishes. It frequents the deepest pools, that never run quite dry and are aërated by trickling rivulets that unite them when in drought the river is at its lowest.

Of Osteoglossum there are two species, O. leichardti and $O$.jardinei, both of which are known variously as salmon or barramunda and are strictly confined to two or three rivers in Northern Queensland. They are nearly allied to the enormous Arapaima of Brazilian rivers and distinguished by the barbules of the lower jaw from that beardless giant.

Adhering to the rule of describing Australian forms chiefly, I have given no account of the acclimatised trout. carp, gourami and the rest. 


\section{Principal Fresh-water Fish}

\section{Perches}

Pseudoambassis castelnaui.

Ambassis agassizii.

Ctenolates ambiguus (Golden P.)

C. flavescens.

C. chrystyi.

Dules haswelli.

Murrayia guentheri.

M. cyprinoides.

1r. bramoides.

M. riverina.

Apogon guentheri.

Nannoperca australis.

$N$. mierince.

Macquaria australis.

Therapon cuvieri.

T. richardsonii (Silver P.)

T. niger.

T. unicolor.

Riverina fluviatilis.

Oligorus macquariensis (Murray Cod.)

O. witchelli (Murray P.)

Erythrichthys nitidus.

\section{Gobies}

Aristeus.

Eleotris coxii.

Atherinida: Nematocentris nigrans.

Gadopsis marmoratus (Black fish).

G. gracilis.

G. gibbosus. 
Chatossus richardsonii (Fresh-water Herring).

C. crebi.

Galaxias ${ }^{1}$ punctatus.

G. kreffiti.

G. scribi.

G. delicatulus.

G. atlenuatus.

G. planiceps.

G. ocellatus.

Siluroids

Copidoglanus tandanus (Catfish).

I'lotosus.

Neoplotosus.

Arius.

\section{Salmonide}

Retropinna.

Prototroctes ("Grayling").

Hemirhamphus regularis (River Garfish). Arrhamphus sclerolepis.

Gonorhynchus greyi.

\section{Chetodontide}

Toxotes jaculator (Archer Fish), (Q.)

Dascyllus aruanus.

\section{Ganoidei}

Ceratodus forsteri (Lung-fish or Baramunda), (Q.) C. miolepis.

\section{Osteoglossid e}

Osteoglossum leichardti.

1 The only marine Galaxias is G. nebulosus. 


\section{Part III.-SEA FISH}

\section{SEA FISH}

THE following is a synopsis of the chief fish dealt with in the present section.
Sharks (Cestracion, Blue Pointer, Thresher, Grey-Nurse, Wobbegong, Chondropterygii Saw-fish and Hammerhead.)
Rays (Stingray, Fiddler, Angel-fish), Elephant-fish, allied to our Chimæra.
Perches (Black rock-cod, Wirrab, old Wife, and Salmon).
Breams (Schnapper, Tarwhine, Black Fish (N. S. W.), and Black Bream.
Sea Scorpions (Red rock-cod and For- tescue).
Mackerels (Pilot-fish and Remora).
Acanthopterygii Carangidæ (King-fish, Samson-fish, Tailor, Trevally, and Yellowtail.
Mullets (Sea Mullet, Sand, and Flat- tailed Mullet).
Jewfish and Traglin.
Barracoutas.
Nannygai.
Flatheads. 
Pharyngognalhi $\left\{\begin{array}{c}\text { Groper, Pig-fish, Parrot-fish, "Rock- } \\ \text { Whitings." }\end{array}\right.$ Anacanthini.$\left\{\begin{array}{l}\text { Sole and Flounder (Pleuronectida). } \\ \text { Beardie (Gadida). }\end{array}\right.$ Catfish.

\section{Herrings.}

Physostomi . . Sergeant Baker.

Garfish and Flying-fish.

Eels.

Plectognathi. , $\begin{gathered}\text { Leather-jackets, Coffer-fish and Toad- } \\ \text { fish. }\end{gathered}$

Lophobranchii . Sea-horses and Pipe-fish.

Petromyzon . (Lampreys: Geotria (S. A.), and Mordacia (Tas.)

Cirrostomi , Mudhopper (Periophthalmus).

\section{Sharks and Rays}

The sharks of Australian waters, of which there are approximately a dozen species, are a good deal more terrible in print than in their native element.

I can well recall on my first afternoon in Sydney seeing a small sailing-boat overturned, the crew floundering in the water. Next moment enter on the scene, not a hundred yards away, a shark at least six or seven feet long. Nothing happened, however ; and the shark was doubtless frightened by the commotion and made good its escape.

In this aversion to encounter with man most sharks are of the same opinion as the snakes. They avoid trying conclusions where possible. That sharks are so insignificant a factor in colonial death-rates is partly due to the precautions taken against them, all bathing places being carefully railed in with bars so close together, that only 
an occasional octopus manages to squeeze its accommodating body through.

Moreover, those bathing from the open beaches are careful to keep in their depth and in "white" water, i.e., where there is a sandy bottom against which any intruders would be at once seen.

Quite the largest shark I ever saw, apart from our own harmless Basking Shark (a representative of which occurs, by the way, in Australian waters ${ }^{1}$ ) was a Tiger Shark (Galeocerdo) which lay alongside our steamer off Cairns and measured only a few inches short of twenty feet, for its head and tail were respectively opposite the quarter-deck companion and the cook's galley.

The variegated pattern on its back was not unlike that of the Wobbegong or Carpet-Shark of Sydney. Near its head swam the faithful pilot-fish, which was not, however, greatly concerned when its patron presently engulphed in its great maw my largest shark-hook. No sooner, however, had three or four of us grasped the rope and put a steady strain on, than the monster blew out hook and all as if it had been a crumb. This performance was twice repeated with no better success, after which the shark sounded.

The Port Jackson Shark (Heterodontus phillipi), or Cestracion, a small and harmless ground species, is interesting, like Ceratodus, on account of the antiquity of its race. The popular name ${ }^{2}$ is unsatisfactory as, contrary to former belief, it is now known to be equally abundant in several other bays on the Australian coast. With another helmeted species, (H. galeatus), it survives out of four-and-twenty extinct species. Its food would seem to consist wholly of molluses, and it is among the most harmless of its race.

1 Rhinodon. 2 Also known as the Bull-Dog shark. 
The Blue-Pointer (Lamna glauca) is the favourite shark of that particular form of fiction which passes for popular natural history. Writers tell terrible stories of its aggressiveness and ferocity. Many are agreed that it shoots up from the rocky depths with such violence as to drive its shovel snout through the ribs of small boats. One extra-bold chronicler declares that it has been known to leap right out of the water and fall with unerring aim into the boat that has provoked its enterprise, swamping the boat and devouring its occupants. All this may be true. Far be it from me to question it; only, I have had large sharks of this species round my boat by the hour, bringing in schnapper heads galore, the rest being snipped neatly off by the great blue feliows darting to and fro a couple of fathoms below the surface; but they never yet monopolised my attention by butting my boat or leaping overhead. The only shark I ever saw leap completely out of the water was the Fox, or Thresher (Alopecias), when attacking the whale, its natural enemy, though I have seen whales jump out thus when attacked. The best combat of this nature that I ever witnessed was off Moreton Island. We steamed so near, indeed, as to distinguish, with the aid of the glass, the long upper lobe of the threshers' tails, as two of these unflagging belligerents were falling on their ponderous enemy; so near as to plainly hear (so marvellously are sounds carried over the water) the resounding blows and the feeble and ever feebler snorting of the succumbing whale, which would have doubtless sounded out of harm's way but for the forbidding blade of some watchful saw-fish which had made common cause with the assassins. What a combination to face! How long the unequal combat had lasted before our arrival, I am unable to say; but the end soon came, a commotion around the now motionless leviathan plainly indicating that the victors, assisted, 
perchance, by other sharks, were already sampling the blubber.

The Grey Nurse (Odontaspis) is another large and ferocious inhabitant of Sydney waters, and so gregarious in certain spots that several will follow up the hook and get foul of the line, which has given rise to the yarn that when one is hooked, the rest endeavour to free their comrade by breaking the line with their combined weights, a new interpretation of sharks' character that will not meet with general support.

The Wobbegong, or Carpet Shark (Crossortinus), is a much smaller species. I have seen young ones lurking in the rock swimming baths at Coogee, but never heard of their interfering with the swimmers. It has the flattened head and body of most ground-fish.

The Saw-fish (Pristis) is a member of the ray group. Not unlike it, save for its inferior size, the lateral gillopenings, and the two moderately long tentacles beneath the rostral saw, is Pristiophorus, a shark, of which I caught an eight-pounder in Botany Bay. I subsequently presented it to Mr. Walter Rothschild for his museum at Tring.

And last, the Hammerhead (Zygana), which grows to a length of ten or twelve feet (in the Brisbane Museum I saw one even longer) and fights desperately when hooked. A smaller specimen, about five feet in length, swam across our bow early one morning as we steamed out of Keppel Bay and followed some little way, after the manner of its kind, in the ship's wake.

Such are the chief sharks, the others being the huge White-Pointer (Carcharodon rondeletii), Seven-gilled Shark (Notidanus), and others given in the list at the end of this section.

Of the Rays, the most familiar is the Stingray, or 
Stingaree, a monster of which kind I hooked on one occasion by moonlight in Largs Bay, played it on a handline for nearly an hour, and finally lost it through the intervention of others anxious to help.

The Fiddle-fish, so called from its peculiar markings, is not unlike the last, only it lacks the terrible spike in the tail, and is quite inoffensive.

\section{Chimæra.}

The Elephant-fish of Tasmania is allied to our northern

The shark fisheries of Australia are as yet little farmed. The only enterprise shown against these useful but dangerous scavengers, one of which was recently taken in Sydney harbour measuring sixteen feet, and having in its stomach a large dog-collar and a man's waistcoat, is roused by Government rewards; and I recollect a marine at Chowder Bay, Port Jackson, killing several under this inducement. Yet the oil from the liver is exceedingly valuable, and the fins could be profitably exported to China.

\section{Perches}

Having already considered the river-perches, there remains but one of any importance, the Black rock-cod, a magnificent fish which runs to a weight of sixty or eighty pounds, and is very fine eating. Yet it is poor sport when hooked, and comes up like a log, and without any of the dash that marks the last moments of the great schnapper or gallant little black bream. There are several allied Serrani in Queensland waters. The Wirrah, chiefly caught from the shore rocks, is, like the last, tenacious of life. Its teeth are formidable, even for an Australian fish. Mr. Cohen eats this species.

The old Wife of Port Jackson and elsewhere is a remarkable little member of the perch family. The names by 
which it is known in the Melbourne market, "Zebra-fish" or" "Bastard Dory," are considerably more appropriate, as they at least have reference to its transverse bands and general shape. I have dipped them out of the water in a hand-net down at Watson's Bay as they were rooting among the weed-covered piles. I first saw these and many other curious kinds in the excellent aquarium at Melbourne. We have no such aquarium in this country!

Of the Sydney "Salmon" little need be added to what has already been said. It decomposes, like the mackerels, very rapidly after death, and is but poor eating when fresh.

Several cases of fish-poisoning have been traced to this fish. On the coast of New Zealand it is said to take the artificial fly; but the only way I ever saw it taken in Australia was by the aforementioned "jigging" with bare hooks.

Of perches, there are further the Javelin-fish (Pristi poma hasta), Hussar (Genyoroge amabilis), allied to the so-called arrow-marked "Government Bream" (G. sebœ), Gerres, commonly included among the breams, and several other genera.

\section{Breams}

Chief among these is unquestionably the Schnapper (aboriginal : Wollomi), whose praises I have already sung. It is to the bream-family what the tarpon is to the herrings, the tunny to the mackerels, the halibut to the flat-fish. It is the largest, and equally glorious, whether fighting on the hook, or steaming on the dish. Of brightest crimson along the back and sides, it tones off to silver on the belly. The white spots noticeable in small redbream disappear at the second, or "squire," stage. 1

1 It is somewhat curious that one of the only British sea-fish that has different names for the different stages of growth is the redbream, which is first a chad and subsequently (when half-grown) a 
The most striking feature of this fish is the curious protuberance on the forehead of old males, considerably more pronounced in a species caught off the Abrolhos Islands, which has a proboscis like an elephant's trunk.

The Schnapper is a fish of southern climes, occurring only off the southern moiety of the Australian continent, also round New Zealand and the Cape. It is not found, however, much north of Townsville (Q.) ; nor does it apparently occur in Tasmanian waters, which is, however, probably due less to climatic influence than to the absence

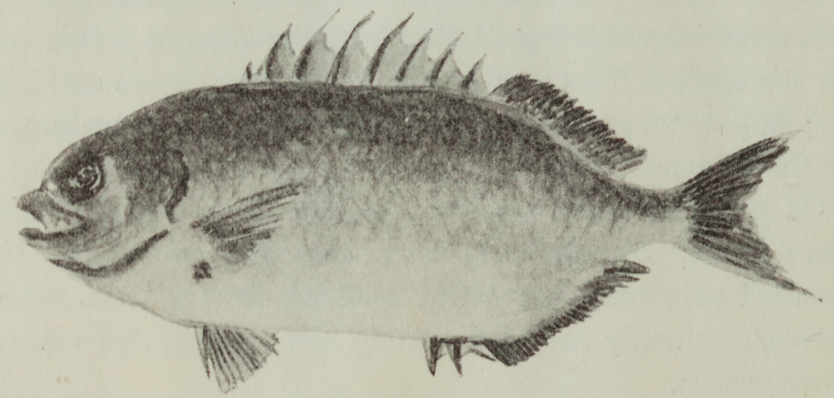

DRUMMER.

of suitable reefs or "bumboras," which furnish it with plenty of molluses for food.

The "school schnapper" are fish of the third year, the largest specimens of all being known in the trade as "natives."

Next in importance to the Schnapper come the Black Bream and Tarwhine, which bear considerable resemblance and are related to our "Gilthead." The Tarwhine is the larger fish and has smaller scales.

ballard. Mr. Wilcocks, well known to sea-fishermen, assures me that there is a bream called schnapper by the Plymouth fishermen. I never heard of it myself. 
The Black Bream, or "Darkie," which, as already remarked, is rather of a silvery hue, is a very foul feeder, though wary enough at the hook, which it only seems to take in salt water, the larger examples up the rivers all falling to the net.

They enter the harbour in summer full of roe. Lake Macquarie (N.S.W.) is a splendid fishing ground for them.

The Sydney Black-fish (Girella), quite distinct from the aforementioned fresh-water fish (Gadopsis) of the same name, feeds on a particular weed and will take no other bait.

The "Drummer" (G. elevata) and allied G. cyanea are equally poor eating.

\section{Sea-Scorpions}

Some five years back I used to catch several kinds of sea-scorpions in the rock pools of the blue Mediterranean,

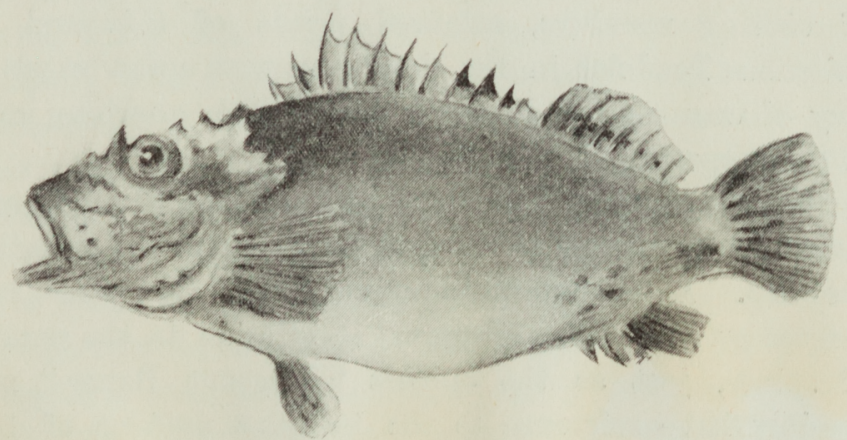

RED Rock Cod.

and my cook had a special genius for making them into most excellent soup.

And in Australian waters, I found two members of the family that call for a brief description-the Red rock-cod, a fish of some attractions, and the Fortescue, a curse. 
The first of these, identical, unless I am mistaken, with the Ruby-fish of Hobart, is a thickset crimson and orange fish armed with many spikes and, like the rest of the family, but a slow swimmer, dwelling down among the weeds. With an enormous gape, a small one will gorge a large schnapper bait.

The wounds inflicted by its spines are not of so serious a nature as those resulting from handling the allied BullRout (Centropogon) or Fortescue (Pentaroge).

The latter is a terrible pest, lurking among the débris in the nets and all but invisible, its spines standing erect in readiness for the unwary finger. And so intense is the pain inflicted by a stab, that I have seen a strong man roll on the ground crying out like a madman.

Just before leaving Sydney, I suggested to the Secretary of the A.F.A., who has since published an excellent little pamphlet on Sydney angling, to post up, for the benefit of visiting members, coloured prints of this and the poisonous Toad-fish in the club-house with a few words by way of warning. I do not know whether anything came of the proposal. Probably not.

I once thought that the name of Fortescue, like Sergeant Baker, had reference to the first Englishman who described the fish. I understand, however, that the name is a corruption of "Forty-skewers," in allusion to the number of spines, just as the epithet "Sergeant Baker" may possibly have reference to the brilliant uniform of that fish.

\section{Frog-fish}

Antennarius marmoratus is a curious scaleless fish, crawling in a manner unlike the majority of the class and related to the Lophius, or Fishing Frog, and to the Tasmanian Saccarius. 


\section{Mackerels}

The Australian mackerel, for all it is known as Scomber antarcticus, differs little, so far as I could make out, from our own, either in its migrations or appearance, or those curious qualities of the flesh that make it decompose so rapidly as to be a dangerous article of food soon after death.

I think, therefore, that it is unnecessary to give any further account of this fish, which, with its relative the "Horse Mackerel" (Pelamys), is exceedingly abundant at certain seasons in and around Port Jackson.

There are, however, two fish of this family in those waters, neither edible, it is true, or at least not occurring in the markets, but of some considerable interest. I refer to the two boon companions of the shark, the Pilot fish and Remora.

One Pilot fish, or at most a second, is usually found in company with solitary sharks, swimming close beside the head, and it is interesting to note, as I have myself seen, that when they attach themselves to a ship, which sometimes happens, they instinctively swim at the bow, and not, like so many other fish, astern.

In books, we find this fish gifted with a wondrous talent for discovering whether or not the proffered leg of pork conceals a hook, and returning to advise its friend whether or not he shall " fear the Greeks. . ." etc. In nature, it behaves differently; and one that accompanied the monster shark we encountered off Cairns, made, as already mentioned, no attempt whatever to warn the shark of the very poorly-concealed hook, which it forthwith seized, not, alas! to hold. The "pilots" are so fond of swimming in company of something large enough to protect them by its presence against voracious albacore and bonito, its cannibal kinsmen, 
that they will accompany the ship for days after the shark has been hauled aboard and despatched, and I knew of one case in which two were dexterously captured in a bucket by the regimental surgeon.

What the basis of the secret understanding between shark and pilot may be, I cannot pretend to guess, but the Remora is even better off, for, thanks to its remarkable sucker, it is conveyed thousands of miles without so much as a stroke of the tail. By nature a strange being, this sucking-fish excited the imagination of the ancients to such a pitch, that they vowed that it could stop large ships, suck the shark's blood, stop lawsuits, and all manner of other wonderful achievements.

In some seas, it is used in the capture of turtle. I took some small remora from equally small sharks in Queensland, so that it seems just possible that the contract may date from an early age, the parties growing to maturity together.

\section{ฑ. Horse Mackerels}

The common Scad, or Horse Mackerel, is abundant in the Channel some years, and I have caught scores on the Cornish coast. Far better represented, however, is the family in Australian seas, where it includes such important species as the King-fish, Samson-fish, Tailor, Trevally and Yellow-tail.

The King-fish ${ }^{1}$ is a very powerful swimmer, and at times numbers are caught just off the north head of Sydney Harbour.

When cruising near the surface, these fish refuse bait of any sort. I hooked one once of 7 or $81 \mathrm{~b}$, and the first run was quite shark-like. They seem to move along

1 The King-fish of Melbourne is the jewfish; that of Tasmania is a barracouta. 
the coast in shoals, harassing all the smaller kinds that come in their way. They are largely caught in the waters of Queensland and New Zealand, being the Haku of the Maoris.

The Samson-fish, a smaller and broader species, seems to be confined within the Port Jackson district, so far at least as that colony is concerned. It is not a gregarious fish like the last.

The Tailor, so-called from its knack of cutting one's lines, has another charming habit, which reminds one of

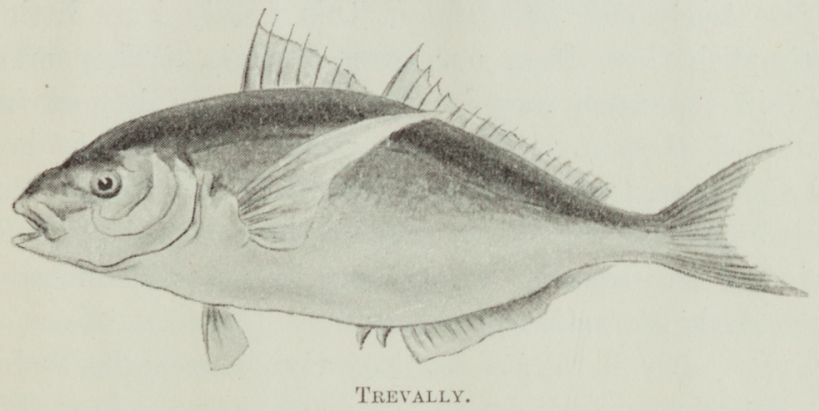

the dingo, of running amuck through shoals of small fish, destroying more than it can possibly eat, and doing great damage to the nets. Allied to the American "Blue-fish," it grows to a length of $3 \mathrm{ft}$. This voracious and widely distributed fish is excellent eating, but, after the manner of mackerels and horse mackerels, deteriorates rapidly.

The Trevally or White ${ }^{1}$ Trevally, of Sydney, otherwise the "silver bream" of Melbourne, is a pretty fish but very poor eating. It wanders some distance up the estuaries.

And last, the Yellow-tail, a favourite fish for bait, and practically identical with our horse mackerel, is chiefly in-

1 Distinct from the Black Trevally (T'euthis nebulosa). 
teresting on account of its almost invariably harbouring a remarkable solitary isopod crustacean parasite in its gullet, a kind of marine woodlouse, such as is found on some of the mullets and leather-jackets. It is uncommon, indeed, to find an example without a guest of this kind.

The singular little Batfish, often exhibited in Sydney shops, is related to the horse-mackerels.

\section{Mullets}

The Australian members of this family have little to distinguish them from our Grey Mullets. They munch sand in the same way for the sake of the little shrimps contained therein. They are equally difficult to hook, indeed few anglers ever try, as the fish is as a rule so cheap in Sydney as to be largely used for bait, the only objection to it in that capacity being that its excessive oiliness is particularly attractive to sharks.

Unless driven inshore by easterly breezes, the Sydney Sea Mullet keep well out in the offing, wherein they differ from the younger generation known as Hard Gut ${ }^{1}$ mullet, which frequent the estuaries and keep generally inshore.

The Sand Mullet, ${ }^{2}$ or Talleygalan (Myxus), the smallest of all, frequents the rivers, but goes down to the sea each winter.

The Flat-Tailed Mullet is also met with in estuaries, where the younger fish will readily take a paste bait, the adult fish being captured only with the sieve. They are less esteemed for the table than the sea mullet.

1 There is no sense in the term, so far at least as the creature's entrails go. Some have treated this Mugit dobula as a distinct species, but it is generally recognised as the young of the sea mullet.

2 The Sand Mullet of Hobart and Melbourne is the same as the Sea Mullet of Sydney. 
At certain seasons, these mullets, impelled by their wondrous migratory instincts, press in dense masses to the surface, near which they invariably perform these journeys. A remarkable instance is on record, in which thousands, intending to migrate from a certain lake in New South Wales to the sea, were stopped by some obstacle in the narrow cut between, and, pressed on by those behind, were driven on to the bank, where they perished in heaps.

\section{Jewfish and Traglin}

The Jewfish is, for all Castelnau said to the contrary, identical with the European Maigre. Of that, few who have handled both could retain a doubt.

It ascends the creeks at all times of the year to prey on yellowtails and other small fish, and not for any purpose connected with breeding. Very little indeed is known of its precise spawning time, and it has been conjectured that this is subject to some variation.

It is the "King-fish" of Melbourne. But indifferent eating, even in the young stage known as "Silver Jew," it is nevertheless served in second-rate (i.e., all but two) Sydney fish-shops under the sobriquet of "schnappercutlets."

These fish grow to a weight of $80 \mathrm{lb}$. and such veterans are of solitary habits; but up to a weight of $20 \mathrm{lbs}$. or 301 bs., they hunt in packs like wolves. Very fine examples have been caught in the summer months in Sydney Harbour and some distance up the Hawkesbury.

Few fish seem to suffer more from parasites. Like some other fish alluded to when describing the capture of the Giant Perch, the jewfish emits sounds under water, a habit turned to account by the fishermen to discover their whereabouts. 
The roes are large and composed of exceeding small eggs; and the air-bladder is a valuable source of isinglass.

The Traglin, a somewhat smaller fish resembling the "silver jew," is much better eating than the last. It is both migratory and gregarious, and I have known a fishing party out on the schnapper-grounds hook these fish for upwards of an hour, both fore and aft, after which there would come a lull, and not another fish of this species would make its appearance during the rest of the day.

\section{Barracoutas}

As the most highly esteemed fish in Tasmanian waters is unquestionably the Trumpeter, so is the cheaper Barracouta caught in vast numbers with the so-called "Maori-jig," in which a piece of red wood serves the purpose of bait and a bent nail does duty for a hook - the mainstay of the poor. Well smoked, and not exceeding a weight of six or eight pounds, it is far from bad eating.

It is related to that singular creature the Frost-fish (Lepidopus) of New Zealand, which is never caught by either hook or net, but picked up at times during a frost along the beaches where the sea has cast it up.

Another connection of this fish is the smaller Sea Pike, taken on the schnapper-grounds. It would be excellent eating if less bony.

\section{Trumpeters}

The Real Trumpeter of the Hobart market is a magnificent fish that grows to a weight of sixty or seventy pounds. It is captured with the handline, and I much regretted having no opportunity of trying this, which must be great sport. I had, however, the good fortune to examine some very fine examples in the well boats that lay off Hobart 
quay, and subsequently to taste the fish at the Club. There is none better in Australian waters.

The Bastard and Silver Trumpeters (Latris citiaris and L. forsteri), in much less esteem as food, are taken on the same reefs, transferred to the well, and thence to perforated fish-boxes in the harbour, where they are kept as long as two months, being fed meanwhile on pieces of shark well scored with a sharp knife. ${ }^{1}$

\section{Nannygai}

Familiar to all schnapper-fishers is this bright-red little fish with the large mouth and eyes; and they always hail

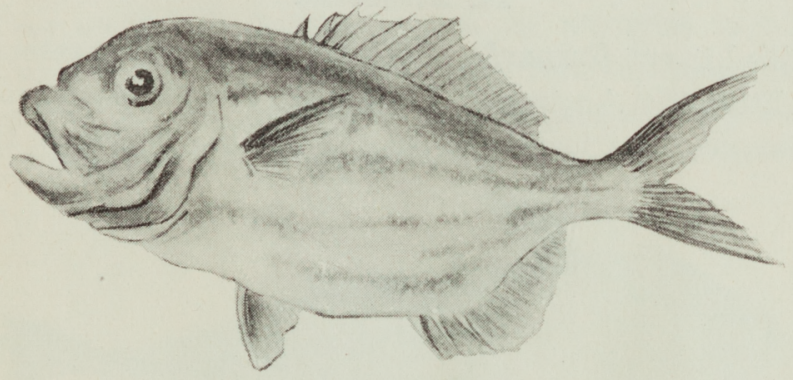

NANNYGAI.

it with pleasure, for it seems not only to frequent the same reefs as the schnapper, but also to feed at about the same time, so that the capture of Nannygai is generally followed by "right colour," as they call the schnapper.

The Nannygai seems to affect fifteen or twenty fathoms of water, and is rarely taken in the harbours or estuaries. To the student of fish it has a particular interest, in that it belongs to the oldest known group of Teleosteans.

1 Schnappers have been fattened in the same way for the market on a diet of potatoes. 


\section{Morwong}

The Morwong, or Jackass-fish, also well-known on the schnapper-grounds, is allied, if I mistake not, to the Hobart Trumpeter. While not occurring itself in Tasmanian waters, it is represented there by a near ally, the Magpie Perch (Chilodactylus nigripes), and is also abundant on the coasts of New Zealand. I have caught Morwong of six or eight pounds in weight just outside Sydney Heads; but as few, if any, small examples are taken close inshore, its breeding grounds must evidently be elsewhere. Chironemus is an allied genus.

\section{Flatheads}

Allied to our Gurnards, which they nevertheless resemble but little, the Australian Flatheads, though repulsive in appearance, are largely eaten. Like the weevers, they

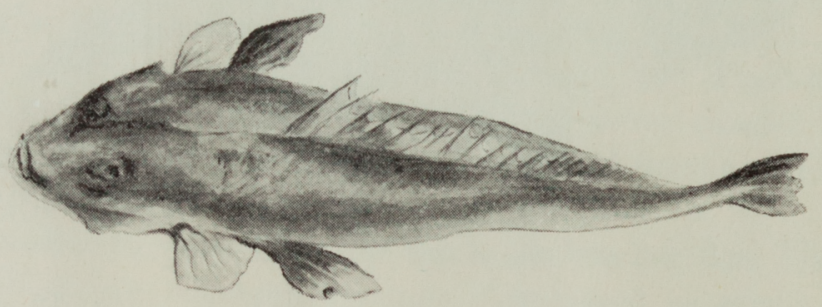

Flathead.

lurk in the sand or grass, and can inflict very painful wounds with the double spines behind the gills.

Although the large ventral fins must assist greatly in swimming, the movements of this family are but slow and a wkward.

Essentially marine fish, one species or other occurring on all the coasts, the flatheads wander some distance up the rivers, where in summer-time they are largely angled for. 
The flatheads are related to the "crocodile-fishes" of the Indian seas, and are known as Rock or Grass flatheads according to the surroundings from which they are taken.

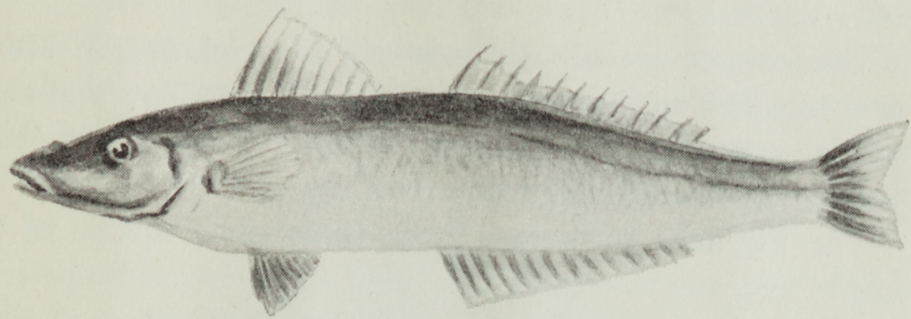

SaND Whiting.

They are not the least related to our weevers, to which I compared them above, though they resemble them much more than do the Australian sand whitings which really are of the same family (Trachinida).

\section{Wrasses}

The Labrida of Australian shores include the aforementioned Blue Groper, as well as the Pig-fish, Parrotfish, and so-called "Rock Whitings."

The Blue Groper, which seems to occur in favourable localities along the entire Australian seaboard, dwells and breeds among the weedy rock pools, where it grows to a weight of forty or fifty pounds. It is a stationary, and not a migratory, species, and is decidedly solitary in its habits.

The largest gropers reach the market irregularly, as they can only be caught with hook and line from the precipitous ledges of the rocks. The trammel would be the correct way of taking these fish, but the sea is rarely sufficiently still for four-and-twenty hours together to 
admit of such a net being shot and hauled quite close to the rocks.

The scales of this and the allled Red species are large and coarse, and their beautiful metallic tints fade soon after death.

The wrasses are all characterised by thick lips, in allusion to which we have the family name Labrida; and the groper excels in this respect, its solid white teeth projecting between lips like those of a negro.

The Pig-fish, so named from these same lips, is of a bright red, the mouth of this comparatively small species having a far greater number of teeth than those of the larger gropers. As this fish is by no means bad eating and is fairly abundant on the schnapper-grounds, I do not know why it so rarely appears in the fish-shops.

The Parrot-fish, likewise caught when schnapper-fishing, is a gaudy species of no more use for food, less if anything, than its feathered namesake.

And lastly, the little Rock Whitings, ${ }^{1}$ so-called (Odax), allied to the Melbourne "Stranger," and the Kelp-fish of Hobart. They are as wretched for table purposes as most of the wrasses. Even the much-esteemed groper is but a second-rate dish.

\section{Flat-fish}

Australian markets exhibit but a meagre contingent of the important order of soft-rayed ${ }^{2}$ fish, which in our seas embrace families of such importance as the Flat-fishes and Cod tribe.

1 Australian waters have no real whitings (Gadidce) for the "sand whitings" are allied to our weevers.

2 It is worth noting that the fresh-water Gadopsis has spinous fins fore and aft, an exception to the Gadus tribe to which it is referred. 
Much of this apparent absence of, at all events, the former of these groups may be due to the want, nay the impossibility, of any systematic trawling on those sandbanks scored by reefs in every direction. It is impossible to believe that under such favourable conditions of food and temperature the Pleuronectidce could be represented by only half-a-dozen insignificant species, the most important of which are the Flounders (Pseudorhombus) and tailless Sole (Synaptura). And only comparatively recently, Savile

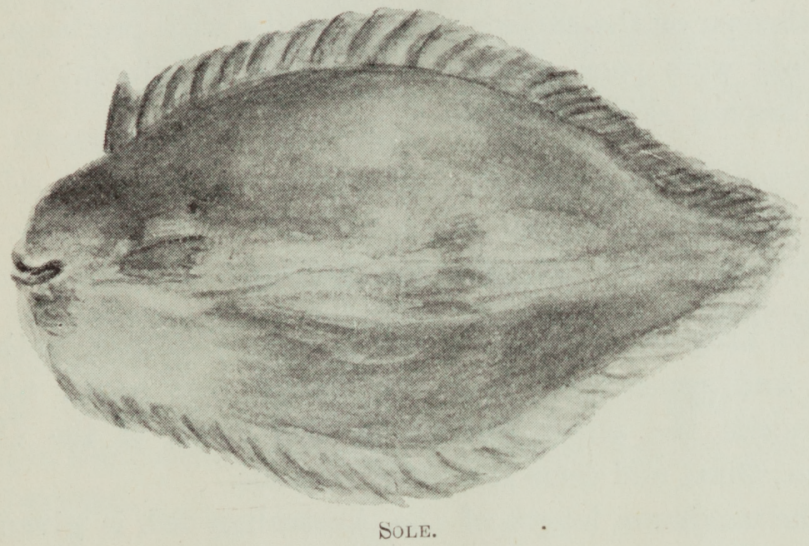

Kent described a large halibut-like species from the Barrier Reef District, not unlike another large flat-fish caught on the New Zealand coast. His Barrier Reef pleuronectid (Psettodes) seems to deserve the name less than most of them, for it swims more like the round-fish, and its development generally is less unsymmetrical.

The Flounders (Pseudorhombus) are at least, so far as Sydney markets go, two in number, the commoner being the small-toothed, spotted kind hooked in the offing. There is an analogous species (Lophorhombus) outside the Heads of Port Jackson. 
The typical New South Wales Sole (Synaptura) is a black, tailless fish of small dimensions. It is the $S$. nigra, and closely allied to a species inhabiting Queensland rivers and much angled for.

Further south there are Solea microcephala and the Melbourne Rhombosolea.

Under the name of $S$. nigra, Tenison Woods gives a figure of a totally distinct fish not unlike our rough dab.

I have seen these soles speared in the rivers, the boat being allowed to drift over them and, if necessary, a little oil thrown on the surface so as to strike with precision.

They were poor specimens, however, indifferent eating and having skin like leather.

\section{Beardie, or Ling}

The Ling of Australian seas is very different, both in size and appearance, from our fish of that name, which resembles the allied Burbot, or Eel Pout, of the Cam, Trent, Ouse, and some few other streams.

The maximum length of the Australian fish is given at eighteen inches, though I never saw anything above half that measurement.

As all the Cod family affect waters of comparatively low temperature, it is not surprising to find this fish absent from Queensland waters; but what is less easily accounted for is the fact that it should also diminish in numbers as we approach the colder seas round Victoria and Tasmania. Such is, however, the case.

As its name implies, it has the beard or barbel beneath the lower lip, characteristic of all the cod tribe with the exception of the common whiting. 


\section{Catfish}

The marine Catfish is hideous like the rest of the Siluridce, of which group, so important in the East, we have in Europe but one member, the great wels of the eastern rivers of Germany. They are well-named from the whiskers, really feelers, that adorn the ugly mouth, and not, as one writer has it, in reference to their nocturnal habits. As a matter of fact, I have angled the whole day long and caught nothing else.

Like all their tribe they are very hard to kill, and unless put out of pain by a merciful tap from a tomahawk, will linger for an hour or more.

The serrated spines are best avoided; and I recollect one little boy, who used to assist me in my deck-fishing, running one into his hand and going to bed for two days, the intense pain being but little assuaged by all manner of poultices and fomentations.

The Chinamen and aboriginals eat them freely, but I believe their admirers among the white men are few and far between.

\section{Herrings}

The Fresh-water Herrings, as they are called, have been already mentioned.

There are, however, a number of important members of the herring family in those seas, which, hitherto neglected in their migrations for want of proper drift-nets to intercept them, are yet, I believe, destined to rank high amid colonial industries. Such, for example, are the Maray, or Pilchard, (Clupea sagax) and the Herring (C. sundaica), or "Silver Belly," which pass northward at midwinter up the coast of New South Wales. Vast 
shoals are recorded, accompanied by barracouta, muttonbirds and other finned and feathered depredators, and imparting an oily appearance to the surface of the sea.

In the waters of northern Queensland, in accordance with the rule of increase of size aforementioned, we find several Giant Herrings, as the 0x-eye (Megalops) and Bony Salmon, which are excellent eating.

The proper development of the herring fisheries was strongly urged upon the New South Wales Government by the recent (1895) Royal Commission on Fisheries. In the evidence taken, it transpired that these herring migrations were not generally noticed in Tasmanian waters, but the herring and maray have both been caught, driven inshore doubtless by porpoises and barracouta, in Sydney Harbour and the Hawkesbury. One witness, a Fisheries Commissioner, calls the Clupea sagax the "True Herring," so there seems to be some little confusion in terms.

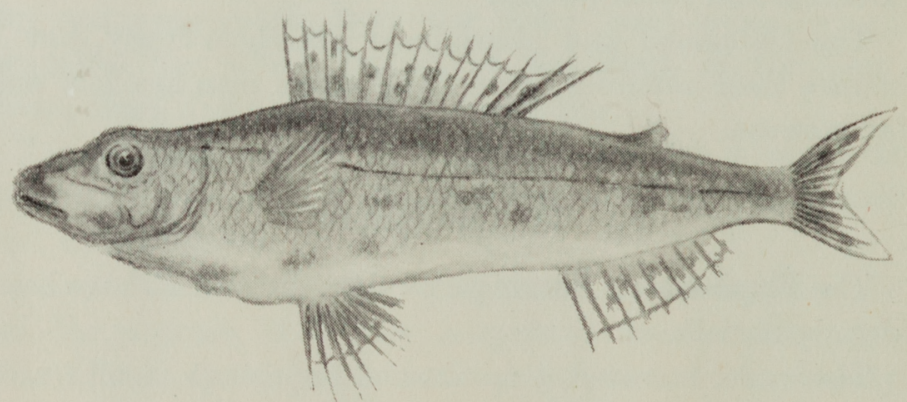

Serseant Baker.

\section{Sergeant Baker}

"This is the only fish of the gurnet family," says Mr. Cohen, "that needs mentioning"; and indeed he might as well have left it out altogether, for it is not a member of 
that family, in spite of the popular name "Red Gurnet," by which it is generally known.

Of course, if an excuse is wanted for the trivial name, it will readily be admitted that this brilliant Sergeant Baker (Aulopus), true kinsman of the luminous fishes and particularly of the formidable-mouthed Tasmanian Plagyodus, is much more like the Sapphirine and Cuckoo Gurnards than their true relative, the Flathead.

It does not seem to be a very plentiful fish inshore, though $\mathrm{I}$ have caught a few on the schnapper reefs, some with the two whiplike prolongations of the dorsal fin denoting male fish.

\section{Garfish, Long-Tom, and Flying-fish}

These Scombresocida, more especially the Half Beaks (Hemirhamphus) are among the most delicate table-fish in the Australian markets.

The marine Garfish (H. intermedius) is larger than the fresh-water species (H. regularis) and equally good eating.

In New Zealand it is known as the "Piper," and angled for with rod and line, the best bait being (as with the atherine) a piece of a brother garfish.

This Sea Garfish feed entirely near the surface, and is consequently much driven into the inlets and creeks by gannets, who perform their magnificent headers out in those waters as they do off our own coasts.

The Short-beaked Garfish is a more northern species, occurring in both fresh and salt water, and is much esteemed as food.

The Long-Toms (Belone), two in number, are the counterpart of our "Green-Bone," and a similar prejudice exists against them. They are said to come alongshore with the early mackerel. ${ }^{1}$ According to Tenison Woods, the Austra-

1 This is also the case on the Devonshire coast, and in a previous work I recorded the same habit of the garfish in the Baltic Sea. 
lian Long-Toms do not take the hook; but I think this is open to doubt, as our garfish, a nearly allied if not identical species, takes the hook freely, and I have caught it on both whiffing and drift line.

Flying-fish are so plentifully distributed over the warmer waters of the globe, and have had so many biographers, that they need little description here.

One or two species are said to inhabit our own Channel at certain seasons, but on this I remain sceptical, as I have fished every part of the Channel for ten or fifteen years, and never yet saw one there.

The preferable explanation of those species that are washed ashore would seem to lie in their having possibly been thrown overboard, or at least lost, by homeward-bound passengers and sailors, with whom these dried flying-fish are favourite trophies.

As a rule, they are merely dried and not artistically mounted, and a few days of re-immersion in the sea might easily restore them sufficiently to puzzle any but an anatomist.

In Eastern seas, however, more especially on hot, still days, they are generally in evidence. I have also noticed that they occur in shoals or patches, and-merely a coincidence, doubtless-I noticed none within two or three miles of the line, which I have crossed in March and October.

There are two species ${ }^{1}$ conspicuously distinct in the matter of size, the larger having a graceful and prolonged flight and even changing its course once or twice, merely dipping to the surface as if to renew its strength by wetting the relaxing wing-membranes.

I have watched these beautiful creatures by the hour and in all weathers. The proper place from which to

${ }^{1}$ As a matter of fact, two score would be nearer the mark. I refer here merely to the two most common. 
observe their method of quitting the water is the bow; but after having closely watched thousands of them through strong glasses, I cannot give as emphatic an opinion as I should like on the oft-discussed question of whether the wings vibrate like those of birds. Indeed the answer must, I think, rest with the anatomist rather than with the casual observer, since these little beings traverse the air at so great a rate, at an angle with the ship's course that renders observation peculiarly difficult and at some considerable depth below an observer stationed on the top deck.

If the pectoral fins are so constructed as to be capable of this vibration, then I would say, as the result of my own observations, that to some slight extent they do flap in the air, not like those of birds, perhaps, certainly not like those of the bat.

I have seen them best when the sun was off the water, as they made their vertical leap at the surface, and, with a supreme jerk of tail and pectorals, soared into the rarer element and went spinning along at a wonderful rate that soon outstripped the mere sixteen knots of the Oceana.

And I think, too, that travellers have exaggerated the dangers to which these little aëronauts are exposed. Before I had gone a long sea voyage I used to picture them chased by bonito into the open beaks of watchful frigate birds; but all the flying-fish I saw left the water simply when disturbed by the ship's cutwater, and with no sign of enemies either above or below. ${ }^{1}$

The common Exocetus volitans is found in all the warmer seas of the globe.

1 There is a good, stirring plate of this kind in Frédol's Monde de la Mer. 


\section{Eels}

There is something particularly interesting about the Eel tribe, if only for their resemblance to snakes and the prejudices, presumably in consequence, harboured against them as food by Scotchmen, Jews, Mahommedans and Egyptians. The Japanese apparently consume more eels than any other race, and the Tokio eel-shops are of world-wide renown.

Coming more particularly to the eels of Australia, we find the Austral Eel descending, like our own species, to spawn at sea. It is a large fish in those waters, having, like the conger, a long and feathery dorsal fin and slender, beak-like jaws armed with a large number of small, very pointed teeth.

Besides this, there are the common Conger, not the least altered from what it is in northern latitudes, and another large pike-eel (Murcenesox bagio); and, lastly, the Green Eel (Murcena afra), a ferocious sea-eel found on the east coast.

\section{Leatherjackets, Coffer-fish and Toad-fish}

Under the group Plectognathi, we have some remarkable fish characterised by serrated spines on the back and skin of such exceeding toughness as to have obtained for one genus the appropriate name of Leatherjackets (Monocanthus), the most familiar being $M$. ayraudi.

This hideous fish is more often caught than desired, both out on the schnapper-grounds and close in under the rocks where groper are supposed to lurk.

In this fish there is only one spine on the back, others of the family have two or three, as also a barbule like the cod. The teeth are exceedingly powerful, cutting through gimp as if it were silk. Beneath the tough hide, I was given to understand, lay flesh extremely firm and sweet; but I refrained !

The Yellow-finned (M. trachylepis) and Variable (M. 
hippocrepis) Leatherjackets differ little in habits or appearance from the common species.

The Coffer-fishes (Ostracion), also known from the horns over the eye as Cow-fish, lack the spinous fins of the above, and their skin, still tougher, becomes a veritable coat of mail. The smaller examples are frequently exhibited in curio-shops.

The poisonous Toads (Tetrodon) and Porcupines (Diodon), relatives of the huge but harmless Sunfish (Orthagoriscus), have often caused accidents to those careless or ignorant enough to eat them. Some lads were poisoned in this way at Coogee not many years ago, and a family of three died early in the century from the same cause. The extreme tenacity of life evinced by these fish has already been mentioned.

\section{Sea Horses}

The graceful little Sea Horses (Hippocampus) are common enough in those waters, and quantities are destroyed in Port Jackson by prawn nets. The male of one species carries the eggs in a sac in a loop of his prehensile tail.

There are also Pegasus natans of Queensland and $P$. lancifer of Tasmanian waters, distinguished by very broad pectoral fins; and the grotesque Phyllopteryx, so disguised by the filaments that grow from the bony plates of the body as to be able to hide from their numerous enemies among the long seaweeds, for a part of which they easily pass. There are at least three species.

\section{Lampreys}

The most remarkable Australian form of these is the Pouched Lamprey (Geotria) of South Australia, which can in all probability retain water in its curious throat-pouch during a short drought.

Mordacia and G. allporti, the latter closely allied to the pouched lamprey, are Tasmanian forms. 


\section{Mudhoppers}

The curious little Mudhoppers (Perioplethalmus) of Queensland, allied to the better known Sunghong and White Frog of China, springs in advance of the rising tide and leaps and skips over the wet mud. It climbs into the mangroves on occasion, but I never saw this. Nor, although within a dozen yards of them, could I procure a specimen, as the water was too shallow for even the smallest boat, while the mud on which the singular creatures were disporting was, I knew well, too treacherous for human foot to trust. The eyes can be protruded by the fish at will, and move independently. These fish are related to the gobies.

So much for the principal types of Australian fish. I have studied compression throughout these pages, and have, therefore, been unable to give more than a few words to each family.

A word, in conclusion, on the subject of the Australian fisheries. It was with particular interest that, after having in 1893 given evidence before the Select Committee of the House of Commons on the subject of the British and German Sea Fisheries, I arrived in Sydney just as Mr. Farnell's Commission was issuing its blue-book, a copy of which that gentleman was good enough to give me. The Commission had taken the evidence of upwards of eighty witnesses; and with the exception of such inland waters as Sydney Harbour, there was no complaint of scarcity of fish, the trouble being how best to gather in the harvest of the sea and convey it to the market. Instead of being faced, like ourselves, with an immature flat-fish problem, their chief market fish are rock-dwellers, so that the trammel and hand-line are the main sources of supply, and offer great 
promise for properly directed capital and labour. I endeavoured to give an outline of this in a short contribution to Chambers's Journal, ${ }^{1}$ and the opening is, at any rate, worthy the careful consideration of all who are interested in the sea-fisheries of the world.

\section{Principal Sea Fish}

\section{Sharks and Rays}

Sharks

Cestracion phitippi (Port Jackson Shark).

C. galeatus.

Zygrena malleus (Hammerhead).

Galeus austratis (School Shark).

Carcharius glaucus.

C. brachyurus.

Pristiophorus.

Crossorhinus barbatus (Wobbegong).

Lamna glauca (Blue Pointer).

Carcharodon rondeletii (White Pointer).

Rhinodon (Basking Shark).

Alopecias vulpes (Thresher).

Odontaspis (Grey Nurse).

Notidanus (Seven-gilled Shark).

Rhina squatina (Monk Fish).

\section{Rays}

Pristis (Saw-fish).

Rhynchobatis banksii.

Trygonorhina fasciata (Fiddle-fish).

Trygon (Stingaree).

T. tuberculata.

Urolophus cruciatus.

$U$. testaceus.

1 A. Neglected Australian Industry (Chambers's J., Oct. 1895). 
Myliobatis aquila (Eagle Ray).

M. australis.

M. tenvicaudatus.

IIypnos (Torpedo).

Narcine tasmaniensis.

Raia lamprieri (Thornback).

R. nasuta (Skate).

\section{Holocephala}

Callorhynchus (Eiephant-fish).

\section{Perches}

Serranus damelii (Black Rock Cod).

S. hexagonatus.

S. guttulatus.

Oligorus gigas (Giant Perch).

Enoplosus (Old Wife).

Plectropoma ocellatum (Wirrah).

$P$. annulatum.

Arripis salar ("Salmon").

Lates colonorum (Perch).

Therapon quadritineatus (Trumpeter Perch).

Histiopterus (Boar-fish).

Genyoroge sebce ("Government Bream"), (Q.)

\section{Breams}

Pagrus unicolor (Schnapper).

Chrysophrys australis (Black Bream).

C. sarba (Tarwhine).

Girella iricuspidata (Black Fish of N. S. W.)

$G$. elevata.

G. cyanea. 
Sea Scorpions

Scorpana cruenta (Red Rock Cod).

$S$. cardinalis.

Pentaroge marmorata (Fortescue).

Centropogon robustus (Bull rout).

Sebastes percoides (Gurnet Perch).

\section{Mackerels}

Scomber (Mackerel).

Auxis (Horse-mackerel).

Naucrates ductor (Pilot-fish).

Echeneis remora (Remora).

Thynnus pelamys (Bonito).

Zeus australis (John Dory).

\section{Carangid $æ$}

Temnodon saltator (Tailor).

Seriola lalandii (King-fish).

S. hippos (Samson-fish).

Caranx georgianus (White Trevally).

C. trachurus (Yellow-tail).

Psettus argenteus (Bat-fish).

\section{Mullets}

Mugil dobulus (Hardgut Mullet).

M. grandis (Sea Mullet).

$M$. cephalotus.

$M$. argenteus.

M. peronii (Flat-tailed Mullet).

Histiophorus gladius (Swordfish). 
SCIÆNIDA

Scicena aquiuc (Jewfish).

Otolithus alelodus (Traglin).

Beryctde

Beryx affinis (Nannygai).

\section{Flatheads}

Platycephalus fuscus (Flathead).

P. bassensis.

P. lovigatus (Rock Flathead).

Trigla kumu (Red Gurnet).

T. polyommata.

Lepidotrigla (Butterfly Gurnet).

\section{WRASSES}

Cossyphus gouldii (Blue Groper).

C. unimaculatus (Pig-fish).

Pseudolabrus (Parrot-fish).

Odax semifasciatus (Rock Whiting).

O. brunneus.

Chætodontid

Scorpis requipinnis (Sweep).

\section{Cirrhitid}

Chilodactylus (Morwong).

C. macropterus (Silver Perch, Hobart).

C. fuscus (Carp).

Latris (Trumpeter).

L. hecateia.

L. cilaris.

Chironemus. 


\section{Trachinide}

Sillago maculata (Whiting).

S. bassensis (Trumpeter Whiting).

S. punctata (Melbourne Whiting).

Kathetosma (Stone-lifter).

\section{Gadide}

Lotella marginata (Beardie).

\section{FLAT-FISH}

Synaptura nigra (Sole, N. S. W.)

Pseudorhombus russellii (Flounder).

P. multimaculatus (Small-toothed Flounder).

Solea macleayana (Narrow-banded Sole).

Plagusia unicolor (Lemon Sole).

Rhombosolea bassensis (Sole, V.)

R. plesoides (Flounder, V.)

\section{SCOPELIDE}

Aulopus (Sergeant Baker). Plagyodus.

\section{Clupeide}

Clupea sagax (Pilchard).

C. sundaica (Herring).

MuræNid

Conger vulgaris (Conger Eel).

Anguilla australis (Eel).

Murcenesox cinereus (Silver Eel).

Murcena afra (Green Eel). 


\section{Plectognathi : Sclerodermi}

Monocanthus ayraudi (Leatherjackets).

M. rudis.

M. granulosus.

M. oculatus.

M. peronii.

M. lippocrepis.

Ostracion (Coffer-fish).

O. diaphanus.

O. auritus.

O. lenticularis.

\section{Gymnodontes}

Tetrodon scelenitus.

$T$. hamittonii.

T. richei.

Scombresocid 2

Ilemirhamphus intermedius (Garfish).

Belone ferox (Long-Tom).

Exocatus volitans (Flying-fish).

\section{Siluride}

Cnidoglanis megastoma (Catfish).

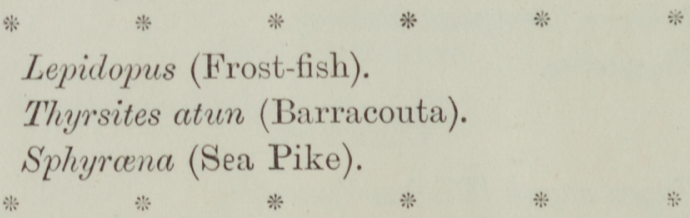

My work is done. I have given within small space some account of the vertebrate fauna of Australia. Another year will doubtless bring along a better handbook on the subject. Meanwhile let me hope that the foregoing notes may be of some slight use until that much needed volume arrives. 
APPENDIX 



\section{THE INVERTEBRATES}

IT was originally intended to confine this little handbook to an account of the habits of the vertebrate fauna of Australia, and as such, indeed, it must lay what claim it may to the reader's attention.

While the remainder, however, was in the press, I have embodied in the present Appendix a few notes, on similar lines, on some of the most important Orders among the invertebrates, those chiefly which have something of a commercial interest.

This explanation may perhaps serve as an apology for the small space devoted to the insects, which are briefly reviewed in a synopsis based for the most part on the contents of Australian museums and information kindly furnished by some of the curators and their assistants.

The Molluses, Spiders, Crustaceans, and a few yet lower forms, are respectively the subjects of similar short chapters. 


\section{THE MOLLUSCS}

\section{i. Shell-Fish}

THE Shell-Fish which, with the cartilaginous Cephalopods, compose this soft-bodied class, serve a variety of purposes.

The Oyster, Cockle, Scallop, Snail, and others furnish food; others are used to hold liquids or other matter, as the drinking. shells mentioned by Juvenal, the salt-cellars alluded to by Horace, and, more recently, the mussel-shells in which, to this day, colourmen sell gold and silver paint. In New Guinea and elsewhere cowries and some other shells are used as currency. In Japan, Brazil, and the Sandwich Isles we find, as the conches of olden time, shells serving as trumpets. In the Admiralty Group they are fashioned into various household tools. In China they make window-panes. And all the world over pearls and mother-of-pearl, as it is called, enter largely into the decorative arts. These last, and the edible oysters, are the only Australian molluses of any importance.

I need not do more than mention such a typical Australian shellfish, of interest only to the collector, as the Cowry (Cypara australis) and its beautiful ally, the "Morning Dawn" (C. aurita), the two-beaked Weaver's Shuttle (Radius volvula), a number of Trumpet Shells, the large and handsome Rock Shells (Murex), a Winkle (Trochocochlea constricta), the Mitres, Spider Shells, Screw Shells, and burrowing 0lives.

Of like unimportance, economically speaking, are the highly-prized Cones, Violet Snails, and Wentle-traps (Scalaria pretiosa, \&c.), some 
of which eject, when alarmed, a green or purple fluid. There is also a limpet (Patella tramoserica), worthless save to the aboriginals.

Lastly, the Pheasant Shells (Phasianella), three Mussels (Myilus hirsutus, $M$. latus, and $M$. rostratus), the Fresh-water Snails, Worm Shells, and Tasmanian "Mutton Fish" (Haliotis levigata).

Of more importance to ourselves than all these together are the Oysters. The chief commercial oysters of Australia are the Rock Oyster (Ostrea glomerata), Mud 0. (O. angasi), and Drift 0. (O. subtrigona). The smallest and sweetest are the first-named, ${ }^{1}$ of which I have gathered quantities from a little-visited reef not twenty miles out of Sydney. The larger Mud $\mathbf{0}$., however, has the best reputation of all three.

In the Queensland estuaries, side by side with the queer "fish out of water" aforementioned, may be seen the spectacle, novel to the visitor from home, of oysters adhering to the horizontal offshoots (called "cobbler's pegs") of the White, Red, and Orange Mangroves. The Keppel Bay oyster-beds, which are among the finest in Australia, owe their excellence largely, I believe, to $\mathrm{Mr}$. Savile Kent, lately in the employ of the Queensland Government. As in many other phenomena of that land of the south, the tables are turned in the relations between oysters and whelks. Whereas at home the latter is a terrible plague among the oyster-beds, out there the bivalve survives the struggle, adhering to the whelk's shell and ultimately stifling the occupant.

The Sydney oyster-fisheries are to all appearance in an unsatisfactory condition, greed and improvidence having here, as elsewhere, achieved the inevitable result. The Act of 1880 , as well as that framed four years later to supersede it, seems to have been a dead letter, as the Crown lands on the foreshore have in places been stripped to the verge of depletion. The recent Royal Commission (1895) plainly advocated the "large area" system of lease, blaming without reserve the Fisheries Department for having instituted no experiments and furnished no data with regard to that most pressing difficulty, the eradication of the worm disease; the great essential being that the lessees shall maintain sufficient stock and clear the areas of shells and like débris.

Besides the dreaded mud-dwelling worm (Polydora), there is another serious cause of loss in the visitations of a blood-red organism

1 Considered by many as a variety only of the Drift 0yster. 
(Glenodium) which periodically invades the waters of Sydney Harbour and Port Stephen in countless myriads, and does great damage among the beds.

But the oyster's arch-enemy in the antipodes is not, from all accounts, the dog-whelk, sea-urchin or starfish, mussel or worm, or other lowly organism, but man himself, the all-destroyer, who has already ruined almost every once prolific oyster-fishery on the mainland, as well as those of Southport and Recherche Bay in Tasmanian waters.

The Pearl and Pearl-Shell industries are practically confined to the two colonies of Western Australia and Queensland, though the capital embarked is largely from Sydney and Melbourne.

The chief districts in Queensland are in the vicinity of the Barrier Reef and Thursday Island, and also in the Gulf of Carpentaria. The Japanese and Malay divers rarely work at a greater depth than seven fathoms.

Pearl Shells average a weight of three or four pounds per pair, though many specimens weigh more than double. The destruction of "immature" shell is very great. The value of this Meleagrina margaritifera varies from $£ 50$ per ton to rather over three times the figure. In his magnificent monograph, ${ }^{1} \mathrm{Mr}$. Kent gives a most interesting account of the various kinds.

The legislative powers of the Queensland Government extend, it must be borne in mind, to the outer edge of the Barrier Reef, and there are strict provisions for the regulation of the fishery and the protection of the "fish."

\section{ii. Cephalopods}

The Cephalopods include the Octopus, Nautilus, Cuttlefish and squid.

These creatures, repulsive for the most part to our way of thinking, are exceedingly plentiful in Australian waters. In Sydney Harbour, for instance, there are enormous 0ctopus, and one of these hideous creatures crawled on one occasion aboard a Neutral Bay ferry-boat and frightened one of the passengers into a fit.

In great demand for bait, these creatures, known locally as

1 Tine Great Barrier Reef of Australia. 
"star-fish," are mostly caught with a grapnel abreast of a steep wall just inside the Heads.

These cold-blooded molluses have a heart and regular circulation. Besides crawling over the ground, the cephalopods are able to dart backwards by expulsion of water through a cartilaginous tube.

Forward they cannot move nor sideways, and of course the rowing and sailing of the Argonaut, ${ }^{1}$ whose exquisite shell is sometimes cast ashore south of Sydney, is purest fable.

The 0ctopus has a beak like unto a parrot's, and eight arms; the Squid (Loligo) and Cuttle (Sepia) have ten "arms" and are therefore classed as decapods.

There are, further, the above-mentioned Argonaut and the Pearly Nautilus ( $N$. pompilius), the former being "unattached" in its shell and breathing with the aid of two gills only, the latter having four gills and being a permanent and fixed occupant in its beautiful partitioned abode. It was formerly thought that the Argonaut was, like the hermit-crab, but a temporary inmate, but it has since been clearly demonstrated that the arms secrete the substance of the mantle, and that the female, moreover, deposits her spawn in its recesses.

\section{INSECTS}

Some apology has already been offered for the very limited space devoted to this important class. They are, as in all warm countries, in great evidence in Australia, as the visitor soon realises. Mosquitoes, without their peers elsewhere, receive the steamer at every port of call ; those who reach the country vid Brisbane will not fail to notice the gigantic ant-hills at the southern end of the Albany Pass; everywhere in the bush there is a plague of viviparous blowflies; public buildings and private are destroyed by the socalled "white-ants;" and a few "silver Fish," are certain to wriggle from one's luggage long after the land has been left behind.

All that is given in the following pages is a mere list of the commoner butterflies and moths, the bees, wasps and ants, and the beetles and some few other typical forms.

1 Vide Montgomery's Pelican Island. It is confused by some writers with the "Portuguese Man of War" (p. 280). 


\section{i. Butterflies and Moths}

The southern parts of Australia are not apparently very rich in Lepidoptera. Of course, in the more complete museum collections (notably Adelaide) the visitor is struck with the number and beauty of the specimens; but the casual observer will notice a far greater abundance up in Queensland.

Indeed, of the total number of Australian butterflies at present named-something under three hundred, not fifty hail from the southern districts. New Zealand is even poorer in its butterflies.

The following are prominent in most of the museums :-

\section{A FEW BUTTERFLIES}

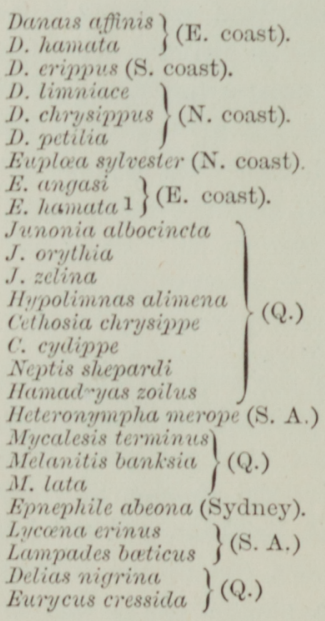

$\left.\begin{array}{l}\text { Danars affinis } \\ \text { D. hamata }\end{array}\right\}$ (E. coast).

D. erippus (S. coast).

D. limniace

D. chrysippus (N. coast).

Euploa sylvester (N. coast).

$\left.\begin{array}{l}\text { E. angasi } \\ \text { E. lecmata } 1\end{array}\right\}$ (E. coast).

Junonia albocineta

J. orythia

J. zelina

Hypolimnas alimena

C. cylippe

Neptis shepardi

Hamad yas zoilus

Heteronympha merope (S. A.)

mycalesis terminus.

1. Lata

(Sydney).

$\left.\begin{array}{l}\text { Lycona erinus } \\ \text { Lampades baticus }\end{array}\right\}$ (S. A.)

$\left.\begin{array}{l}\text { Delias nigrina } \\ \text { Eurycus cressida }\end{array}\right\}$ (Q.)

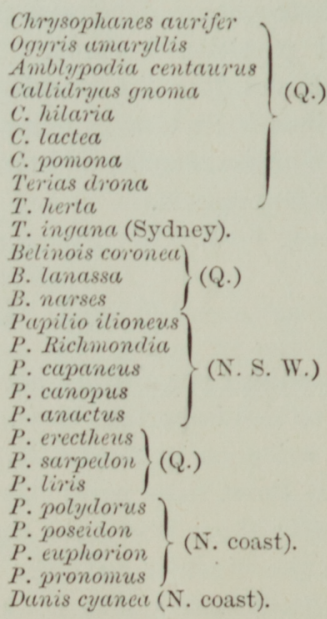

MOTHS

Charocampa celcrio
C. pallicosta (S. A.)

C. erotus

Synemon mopsa (Q.)

S. scaria

S. sophia (S. A.)

Procris apicalis
P. tricolor (Q.)

Nyctalemon orontes (a handsome black moth that $I$ have caught in the is. lands in Keppel Bay).

Hemairis hylas.

Macroglossee (Humming-bird Hawk. Moth).

Cequosa triangularis (one of the heavyflying Smerinthinct).

Protoparce convolvuli (Sydney).

Metamimas australasice.

1 The famous "Bugong" on which the aboriginals feed greedily. 


\section{BOMBYCES}

Agarista casuarince

A. latinus

A. levini

Apina callisto.

Cossus cinereus.

Distolmia lanceolata.

Zeuzera eucalypti.

Sebeda obscura.

Odonestes australasice.

Leptosoma annulata.

Pinara cana.

Deiopeia pulchella.

Darala ocellata.

Nephelodes rubiolans.

Dasygaster epinidoides.

Apamea floiescens.

Calogramma festiva.

Levcania truncata.

L. cramboides.

L. extrania.

L. vada.

Corula geometroides.

Nonagria abdominalis.

Agrotis munda.

A. suffusa.

Ochroplewa tortisigna.

Hadena bistrigula.

Xylina serrata.

Anchinis composita.

Pantydia sparsa.

$P$. recondita.

Acontia pulchra.

Abrostola transfixa.

Plusia argentitera.

P. subsidens.

$P$. verticillata.

Astura clytusalis.

Carcantia pterophoralis.

Hydiocampa tullialis.

Ennychia melissalis.

Pyralis farinalis.

Rhodaria lancinalis.

Helicausta enselma.

$H$. elecoodes.

Palparia aurata.

Chalarotoma parabolella.

Thudaca obliquella.

Eochrois protophaës.

Chryptophasa.
Teara tristis.

Damima banksia.

Hylarora bicolor.

H. caustopis.

Doratifera denotata.

D. longerans.

Antherac helena.

A. eucalypti.

Hepialus 1 australasia.

Pielus tasmania.

P. labrrinthicus.

Charagia lignivora.

Zelotypia stacyi (the Giant Swift)

\section{NOCTU E}

P. secundaria.

Cosmophila xanthindyma.

Diatenes subsignata.

D. gerula.

D. chalybeus.

Prometopus inassueta.

Anophia acronyetoides.

Praxis coivus.

$P$. inordinata.

P. porpleyretica.

Dasypodia tricolor.

D. cymatodes.

Sericea anops.

S. spectans.

S. diops.

Ophiodes disjungens.

Lagoptera orbifera.

Ophiusa senex.

Carthoa saturnioides.

Grammodes oculicola.

Fodina ostomis.

Calliodes orbigera.

\section{PYRALES}

Botys pharaxalis.

Phalangiodes neptalis.

Godara comalis.

Lexcochroma tolumnialis.

Margaronia arcusalis.

\section{TINEE 2}

Philobata agnesella.

$P$. auriceps.

$P$. pantinella.

$P$. vibella.

$P$. pretiosella.

Hopletica repandula.

Lita solanella.

1 To the Hepialida belongs the remarkable $H$. virescens of $\mathrm{N}$. Zealand, which is slowly killed by a parasitic vegetable.

2 These include the too familiar clothes-moths. 


\section{CRAMBI}

Thinasolia gramella.

T. relatalis.

Somnoceros crambella.

\section{TORTRICES}

These include the famous, or infamous, Codlin Moth (Carpocapsa pomonana), that does so much damage among the apple orchards, as well as the allied C. trajectana, C. conficitana, \&c.

\section{ii. Bees, Wasps and Ants}

The new arrival (or "new chum") in Australia is generally assured that the wild-bee has no sting; which, though unquestionably true of the native honey-bee (Trigona), by no means applies to the swarms of imported European bees (Apis mellifica) which have got wild and retain all their old habits.

The aboriginals have an ingenious method (of which there exists a parallel among some of the American Indians) of making the wildbee lead them to the nest. A little tuft of white down is, with the aid of a stick, gummed on the first bee handy, and the latter, thinking itself laden, forthwith makes what is appropriately known as a "bee-line" for its storehouse, followed at high speed by the blacks, who presently scale the tree-perpendicular or otherwisecut out the nest, and feed to repletion.

Australian honey has, if anything, too sharp an aftertaste to please the visitor, though improved methods of culture are yearly raising the standard.

Among the most remarkable of Australian bees is the Carpenter (Lestis bombylans) allied to the boring-bees of other lands.

\section{BEES}

Lioproctes vigilans (W. A.)

L. elegans.

Lamprocolletes cristatus)

L. obscurus

$L$. chalybeatus

L. fulvus (Q.)

L. aurifions

L. punctatus

L. cupreus

L. versicolor.

L. cinereus

L. plumosus

L. ruficornis

L. nanus

L. argentifions

L. bicolor

L. bimaculatus

L. irroratus
L. cristatus (N. S. W )

Dasycolletes humerosus (V.)

Anthoglossa plumata (W. A.)

Euryglossa terminata)

E. depressa

E. nigra (N. S. W.)

E. villosula

E. tricolor

E. rubricata

E. flavopicta (W. A.)

E. blanda

E. jucunda

$\left.\begin{array}{l}\text { Paracolletes crassipes } \\ P \text {. abdominalis }\end{array}\right\}$ (W. A.)

$\left.\begin{array}{l}P \text {. nitidus } \\ P \text {. marginatus }\end{array}\right\}$ (N. coast).

Prosopis cognata !

$P$. amicula

(W. A.) 


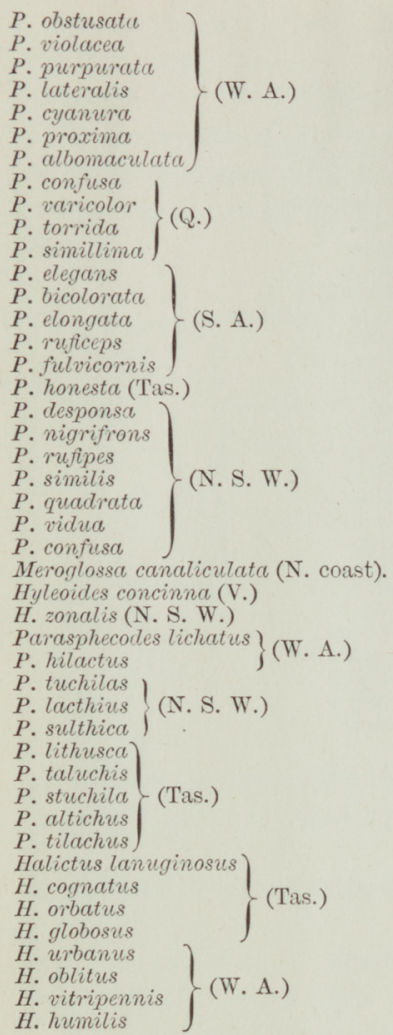

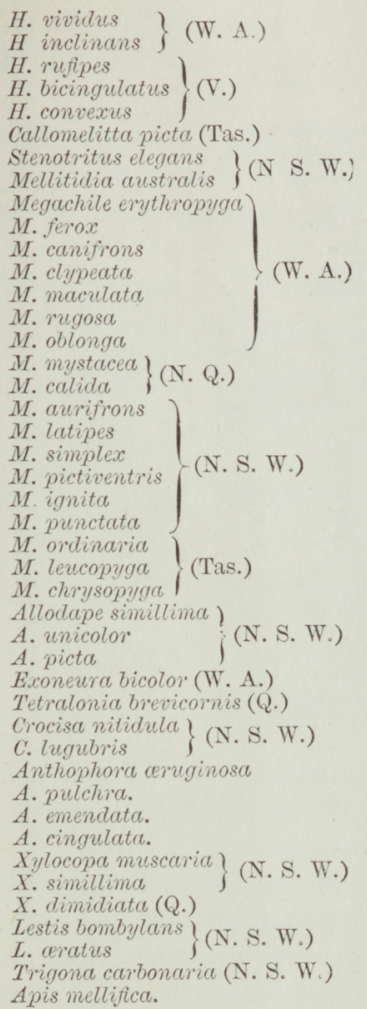

Of Wasps, that blest land has enough and to spare, though it must in all fairness be admitted that, in spite of the length of their sting, their disposition is mildness itself. Some of the more formidable sand-wasps (Monorebia, \&c.), however, inflict terrible stings. Some of the large, black Tasmanian wasps stock their nests with spiders, and one red species, found on the beaches of that island, has the longest sting of all.

The solitary Eumenes is one of the most remarkable wasps of those parts. Round each egg this insect constructs a perfect little mudcell, which is presently stocked with a miscellany of grubs for the larva to feed on as soon as it is hatched. 


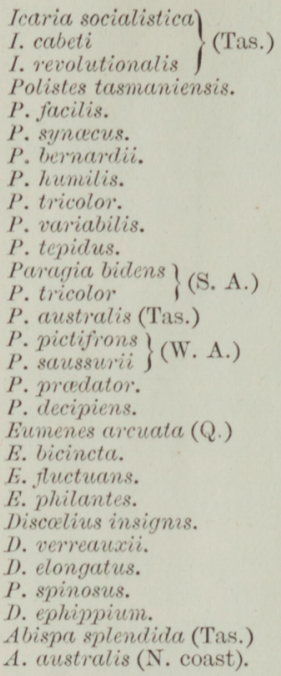

\section{WASPS}

Alastor parea.

A. argentifirons.

A. lachesis

A. albocinctus

A. tuberculatus

A. tasmaniensis

A. picteti

A. clotho.

A. similis.

A. australis.

Rhynchium superbum.

R. alecto.

R. decoratum.

R. mirabile.

Odynerus tamarinus

$O$. vernalis

O. extranars

O tasmaniensis

O. succinctus

O. alastoripennis

0 . diemensis

0 . alaris

O. bicoloratus

0 . neglectus.

O. flammiger.

0 . alariformis.

O. subalaris.

O. cruentus.

o. fluvialis.

Intermediate between the wasps and ants come a number of insects of various habits which form perhaps the chief part of the Hymenoptera.

Of these are the Mutillide, whose wingless females, conspicuous by their large head, sting severely.

These sand-burrowers form, in one sense, a link between the winged wasps and the perfect, wingless ants, for late in life they break off their own wings by pressing them against the earth.

\section{MUTILLIDE}

Mutilla distinguenda)

M. Lacinia

M. lutaria

M. instabilis

M. venusta

M. strigosa

M. morosa

M. rugicollis.

M. perplexa.

M. ignita.

M. ruficomis.

M. afinis.

M. pulchella.

M. rubella.

M. abdominalis.

M. apicalis.
M. aurata.

$M$. viridatis.

M. formicaria.

$M$. carbonarii.

M. maculata.

M. modesta.

II. cordata.

M. metallica.

Myzine signata.

M. sabulosa.

M. unicolor.

M. depressa

M. scabrosa

M. nitida

$M$ vivida (W. A.)

M. abolineata

M. hospes

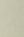

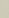


An exceedingly large family are the allied Thynnida, usually classed with the Scoliade, in which the wingless females are distinguished by very spinous legs.

They may frequently be seen in the act of stinging large beetles or grasshoppers, and bearing them off in triumph to provision their nests, which usually lie at the root of some strong-scented native flower.

\section{THYNNIDE AND SCOLIADE}

Thynnus humilis

T. decipiens

T. fervidus

T. simplex

T. nanus

T. variabilis

T. senilis

T. niger

T. intricatus

T. longiceps

T. lucidus

T. flavipennis.

L. trivialis.

T. obscurus.

T. petiolatus.

T. carbonarius.

T. gracilis.

T. dispar.

T. brevicornis.

T. rubripes.

T. adustus.

T. pugionatus.

$T$. volatilis.

T. labiatus.

T. tryphonoides.

T. flavopictus.

T. flaviabilis.

T. eraboniformis

T. quadratus.

T. gravidus.

T. flmbriatus.

T. australis

T. ruficornis

T. connectens

T. morosus

T. oppositus

T. mellens

T. optimus

T. perplexus

T. impatiens

T. affinis

T. modestus

T. tuberculifions

T. constrictus

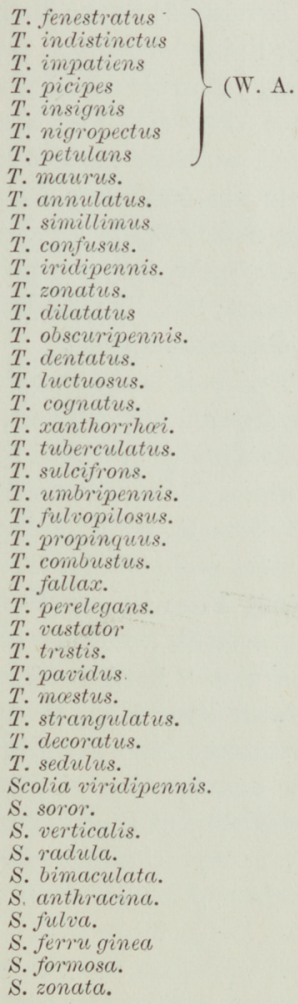

T. fenestratus

T. indistinctus

T. impatiens

1. picipes

T. nigropectus

T. petulans

T. maurus.

T. annulatus.

T. simillimus

T. confusus.

$T$. iridipennis.

T. zonatus.

T. dilatatus

T. obscuripennis.

T. dentatus.

T. luctuosus.

T. xanthorrhei.

T. tuberculatus.

T. sulcifions.

T. umbripennis.

T. fulvapilosus.

T. propinquus.

T. combustus.

T. fallax.

T. vastator

T. tristis.

T. pavidu.

T. strangulatus.

T. decoratus.

T. sedulus.

S. soror.

$S$. verticalis.

S. radula.

S. bimaculata.

s. anthracina.

(Tas.)

The Chrysididce ("Ruby Tails" or "Golden Wasps") may be termed the cuckoos of the insect world, for they deposit their eggs in the nests of bees and wasps, to the ultimate prejudice of the rightful occupants, on whose young the larvæ feed freely. The 
females give, when irritated, a sharp but not poisonous sting. When touched with a stick these little insects instantly curl up into a ball, hedgehog fashion, like our common Pill-Woodlouse (Glomeris).

Far more remarkable, however, are the insectivorous Ichneumonida, which lay their eggs in the larvæ, pupæ, or eggs of the prayingmantis and also of grasshoppers and various butterflies, spiders, and other convenient creatures. Keeping down the hordes of locusts, not only by this means, but also by feeding on them, these insects are simply invaluable to the farmer. The larvæ remain some time within their living birthplace, feeding incessantly on the fatty parts of their host, yet avoiding by wondrous instinct the vital parts until ready to face the world and shift for themselves. Then, they eat their way out without more ado. Besides having a useful sting, these insects are further protected by a very disagreeable odour, which keeps most enemies at a respectful distance.

Of Proctotrupidce, tiny parasitic ịnsects, Australian museums contain many cases ; but, like the brighter hued Chalcida, their interest is only for the entomologist.

Under Pergidce it is that we find the two most interesting groups that still systematically separate us from the ants, to wit the Saw Flies (Tenthredinida) and Gall Flies (Cynipida).

Of the former, the most remarkable is perhaps a Tasmanian species in which the female, with instincts above those of her class, guards her young most zealously for weeks.

To the Gall Flies belong the insects that, by inoculating trees with their powerful, acrid secretion, give rise to the curious excrescences known as "Dead Sea Fruits."

These creatures were long thought to consist exclusively of females, an error that arose from the alternating broods of either sex.

With the enumeration of forty or fifty Australian ants, I bring this cursory glance at the Hymenoptera to a close.

The bush is remarkably prolific in ant-life, and one soon meets with a number of kinds when out shooting, some of which bite severely.

The worst offenders are the Black Ants and so-called Bull-dog Ants. There are also Honey-Secreting Ants, and in Queensland there is one that, added to its other terrors, leaps like a flea. An ally, doubtless, of the Ponerince.

The nests of these ants vary greatly, both in shape, size, and position, from the fungus-like growths on the trees to the afore- 
mentioned great hills. Those that nest in the trees instinctively choose the under-side of the boughs to avoid the claws of opossums and "bears."

A stinging ant that deserves mention is the Harvester, which stores up grain against bad times.

For all their stings, however, none of these ants come near the siafu, an African species described by Willoughby, ${ }^{1}$ which apparently buries its forceps in your flesh and then stands on its head!

\section{ANTS}

Formica agilis.

$F$. detecta.

$F$ virescens.

$F$. intrepida.

F. macrocephala.

F. testaceipes.

F. aurocinctio

$F$. consectator.

F. suffusa.

F. nigriceps.

F. purpurea.

$F$. nugiventris.

F. ephippium.

F. consobrina.

$F$. procidac.

Polyrhachis latreillii.

$P$. femoratus.

$P$. hexacanthus.

Ponera oculata.

P. metallica.

$P$. austialis.

Pachycondyla astuta.
$P$. piliventris.

$P$. bispinosa.

Amblyopone ferminea

A. obscura.

Ecatomma aciculata.

E. punctata.

Myrmecina gratiosa

Myrmecia tasmanionsis

M. sanguinea

M. pilosula

M. jortificatio

M. gulosa,

M. tàrsata.

M. rufinodis.

M. simillimi.

$M$. vindex.

M. pyriformins

Cremeitogaster leviceps

Cryptocerus pubescens.

Atta antipodum.

A. vigilans.

A. spinoda.

\section{iii. Beetles}

Of this important order, the present chapter gives a survey based for the most part on an excellent list compiled by Mr. Tepper, of the Adelaide Museum. As that list is available to collectors visiting the colony, I content myself with enumerating a few species typical of each group.

Of the Carnivorous Ground Beetles, Cincelidce (or Tiger Beetles) and Carabida, Australia has a large muster. Like our common Tiger Beetle, Tetracha australis, Cincindela circumcincta, Distypsidera volitans, and many others, chase their insect prey swiftly along the earth.

Of Carabida, which, like our Bombardier (Brachinus crepitans), emits when handled an acrid vapour accompanied by loud detonation, the largest is the great Queensland Hyperion schroetteri. Other typical species are the bark-boring Pseudomorphina, Agono- 
cheila lutosa, and A. biguttata, Scopodes sigillatus, Carinum anthracinum, C. dispar, and C. ineditum, Helluo costalis, Eutoma purpurata, Catadromus australis, Silphomorpha fallax, S. maculata, and S. quadrisignata, Phorticosomus mucronatus, P. similis, P. felix, \&c.

The Water-Beetles (Dytiscida and Hydrophilidee) and Whirligigs (Gyrinida) are much like our own. Of typical species, mention should be made of Colymbetes lanceolatus of South Australia, Trogus scutellaris, a large Murray beetle, and the still more powerful Hydrophilus albipes, and H. latipalpus, that prey on the perch and other fish.

Next come the little Rove Beetles (Staphylinida), or Cocktails, usually found beneath dead leaves or bark.

Nir. Tepper enumerates some forty species, of which I mention only the singular Apphiana veris and the little red-headed Creophilus erythrocephalus found on carrion. They are allied to our Devil's Coach Horse.

The prominent-eyed little Pselaphida have no special interest; but the Paussida, allies of our Burying Beetles, deserve mention on account of their detonating apparatus, which may possibly keep enemies away from the ants' nests in which they seem welcome guests.

The Silphidce (or Horse Beetles) and Histerida are carrionfeeders and indefatigable scavengers. Beneath decaying bark, too, we may find the Cucujida, Cryptophagidce, and Trogositida. Of the last-named family, Trogosita mauritanica is a common offender in European museum collections, where it does much damage.

Of the Dermestida, the larvæ of which are so destructive among rugs and skins, the Bacon Beetle (D. lardarius) is the worst. It has been thought that a small allied beetle is responsible for much of the destruction attributed to the "Silver Fish."

Passing by the pill-like Byrrihida, I come for a moment to the lamellicorn Scarabs ${ }^{1}$ and Lucanida, among the farmer's most deadly foes, and less baneful only than the weevils and fruit-loving Chrysomelidae (Colorado Beetle and Septimotarsa 10-lineata, \&c.).

These Dung Beetles, as the Scarabs are aptly called, compensate the farmer to some extent by their assiduous manuring of

1 One of these, the celebrated sacred Egyptian Scarab, lays its eggs in balls of dung which it presently rolls backwards into its
burrow. 
the soil. Of the 130 kinds named by Tepper, typical species are Onthophagus penthacanthus, O. cereus and O. hostitis, Bolbocera.s frontalis, Phyllotocus rufipennis, Anoplognathus velutinus and $A$. viridaneus, Schizorrhina xanthopyga and Crytodus piceus.

Of far greater beauty are most of the Buprestida. They vary greatly in size, from the larger Stigmodera, numbering a couple of hundred Australian species, down to Anthaxia, but one-fifth of an inch in length.

These "Cow-bursters," as they are called, burrow in wood and not, as the ancients alleged, in living animals. The female is by far the larger insect. The móst conspicuous among this brilliant throng are the golden-spotted Stigmodera sanguinosa, the blue-andyellow S. yarelli, the little spangled Melobasis 6-plagiata and $S$. pyritosa, and the large yellow Julodimorpha bakewelli.

Of Elateride ${ }^{1}$ (Glowworms, Click Beetles, Fireflies, \&c.), Australia has a long list. They all breed most noxious larvæ. Among the best known are the large Tetralaus fortumni, the reddish Monocrepidius erubescens, and $L$. lachrymosus, so called from the beadlets of moisture with which it is usually covered.

Of the Soft-skinned Beetles (Malacodermata) there are half a dozen families, chief among which are the Telephorince, Rhipidoceridee and Cleridce. So tenacious of life are some of these insects, that they have been known to revive in the killingbottle. They are carnivorous, among the commonest being the hairy-footed Rhipicera mystacina and yellow-banded Telephorus pulchellus. Their habits do not differ materially from those of their English kindred, the "Soldier" and "Sailor" Beetles.

This brings us to the injurious Ptinidce and Lymexylonida, confirmed wood-borers, of which our "Death Watch" is a familiar English type. Apate jesuita is one of the largest and most noxious of Australian types.

The nocturnal Tenebrionida ${ }^{2}$ easily recognised by their pungent and disagreeable odour, include the flattened Pterohelaus hullatus, the grotesque Fie Dish Beetle (Helauts princeps), and the common though beautiful Amarygmus polychromus and Adeiinm similatum.

The Cantharidae have no particular interest in Australia. To them belong the Spanish Fly (C. vesicatoria), the 0il Beetle (Meloe violaceus), and that remarkable parasite of the Mason Bees, Sitaris.

1 To these belongs that hated larva the destructive wireworm.

2 The Mealworm of bakehouses is the larva of $T$. molitor. 
More important are the devastating Weevils, which occur in that land to the number of over ore thousand named species. Each kind seems to have been allotted its own particular sphere of mischief, like the Corn Weevil (Bruchus), the vine-destroying Grass-Weevil (Rhynchites), and a long-snouted Jamaica species which gives its undivided attention to the sugar-canes.

As typical species of these weevils (Curculionide, Brenthide, and Bruchida), it will be sufficient to mention four, the bright-spangled Chrysolophus spectabilis, the acacia-loving Behs bidentatus, Cyrotyphus fascicularis, found in the banksia blossom, and Haplonyx centralis which feeds chiefly on the blue gum.

Two groups of Coleoptera remain, the Longicorns, or Wood Beetles, and the plant-destroying Eupoda.

Of Longicorns, the soft, yellow larvæ of which bore long tunnels or galleries in their native trees, some ten thousand are known to science and nearly seven hundred are already described from Australia.

Of the Prions, there are Cnemoplites edulis, the larva of which is, as the specific name implies, eaten by the aboriginals, who also appreciate that of Eurymassa odewahni.

The Cerambycide include Coptocercus rubripes and C. aberrans, Pharacantha gigas and P. fallax, Pachydissus picipennis and P. sericus, Pempsamacra dispersa, P. pygmaa and P. subaurea, the hairy little Telocera wollastoni and the slender-legged Syllitus parryi.

Under Lamiida are classed nearly a hundred museum specimens, including the clumsy Penthea crassicollis, and the commoner Rhytiphora amicula.

In the last group of beetles, Eupoda, not only is the larva destructive, but also the perfect insect. They swarm in Australia, one genus (Paropsis) alone, out of forty or fifty, being represented by no fewer than 250 named forms. Cassida mera (a Tortoise Beetle), Chryptocephalus carnifex, Calomela sapphira, Edusa chrysura, Paropsis polyglypta and Haltica australis (allied to our Turnip Fleas) are typical forms.

And here we may take leave of the Coleoptera, for of the carnivorous Lady Birds (Coccinellide), the commonest examples of which are the large Coccinella conformis and the beach-haunting Alesia lineola, Australia has but ten genera. 


\section{iv. Locusts and Crickets}

The Locust, ${ }^{1}$ which in some lands spells ruin to the farmer, is comparatively little dreaded in Australia. In Moroceo, for instance, it leaves ruin in its path, and in the early springtime the Moors look eagerly for rain to drown the wandering hordes. A gentleman, residing in London but well acquainted with that remarkable country, assures me that this spring downpour in the Barbary States is almost invariably preceded by snow in the south of England, though in the present year of exceptional weather they enjoyed the much desired rain without the usual condition being fulfilled.

The true Locusts (Acridiida) are well represented, and include the destructive Oedipoda migratoria, though not in very great number. They are confirmed honey-eaters.

The Crickets (Gryllida) include the large Anatostoma, australasice and the black-spotted Ephippitytha trigintiguttata.

The Earwigs (Euplexoptera) also develop some peculiarities in that climate; but the most remarkable members of the family are unquestionably the Leaf Insect (Mantis) and Stick Insects (Phasma). They furnish striking examples of colour protection. Australia is rich in these insects, which can at the right season be procured without difficulty. The larva is carnivorous.

One of the Stick Insects (Lopaphus) ejects when handled a pungent fluid.

The insects need detain us no longer. The Neuroptera embrace some handsome Dragon Flies, as well as the May Fly. The trout are unfortunately not supplied.

Mention of the briefest kind must also be made of the so-called "White Ants" (Termitida) and "Ant-Lions" (Myrmeleontida). Both groups are totally distinct from the true ants. The White Ants, as in South Africa and elsewhere, are terribly destructive; and I recollect the Sydney Museum being closed for some weeks owing to these wretched creatures having undermined the walls and ceilings.

The less noxious Ant Lions are much more interesting. Like

1 The so-called locusts of Australia (like those of America), which fill the summer air with their humming, are really Cicadida. 
our Tiger Beetle, the carnivorous larva lurks in its own pitfall, feeding on such small insects as may fall in.

And of the Caddis Fly, Port Jackson has in its rock-pools a recently-described marine species (Phalanisus), which bears some resemblance to the green Stone Fly (Chloroperla) of the same district.

But the most important, and also the worst hated insect of the group, is the much abused "Silver Fish" (Lepisma saccharina) aforementioned. It is one of the "Spring-Tails," a silvery, scaly little creature exceedingly tenacious of life and, to all appearance, but little affected by changes of temperature. ${ }^{1}$ From a carefu] investigation of books and clothes among which I have on several

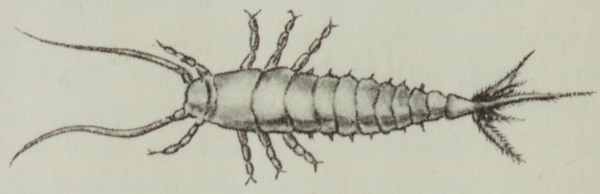

Silver Fisir.

occasions found them, I am inclined to accept the suggestion that theirs is often the case of the dog with the bad name. But the preference of colonials for books in paper covers is some evidence of this creature's raids on the library.

On the Bugs (Heteroptera) and Fleas (Aphaniptera) memory dwells not without qualms. They are varied, exceedingly numerous, and enthusiastic to a degree in the performance of the work allotted them. The fleas more particularly, breeding as they do in the sand, come not as single spies but in battalions.

The only two that have any individual interest have been already named. They are Pulex echidnce and Echidnophaga ambulans, both of which, with a refinement of taste for which colonials have reason to return thanks, affect but one host, the echidna. The latter insect indeed having lost its power of leaping.

Nor is it pleasant to recall the allied Mosquitoes. As all the large cities are on bays or creeks, these bloodthirsty water-nymphs, which pass all their early existence beneath the surface, are terribly

${ }^{1}$ I found two of them alive in my luggage, which was not opened until mid-winter, two or three months after my arrival in England. 


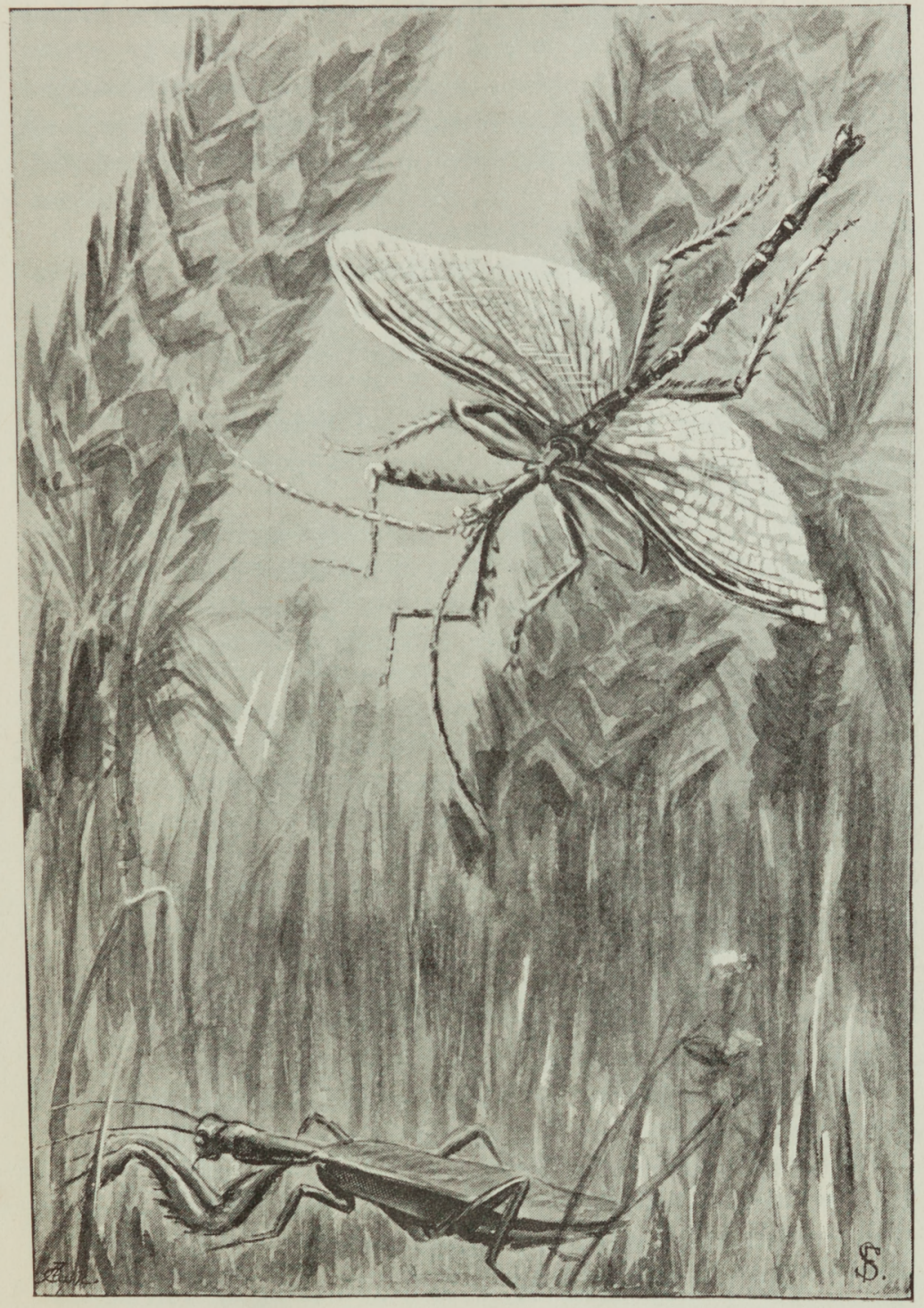

Mantis and Phasila. 
in evidence in warm weather. As only the female insect bites and makes divine music at night, there can be no males in that land. I have learnt to know and respect the mosquito in various lands, but unhesitatingly give a small black demon of the Keppel Bay district the palm for sheer brutality. The chowry and curtains avail not against such hordes; you might as well try a stockwhip and steel armour !

\section{SPIDERS AND SCORPIONS}

Not wishing to prolong this Appendix beyond a very few pages, I shall content myself with mentioning this group in its proper place.

Popularly, they are generally included under the insests, from which, however, they differ in that they undergo no metamorphoses and possess more than six legs.

Australia has some formidable tarantulas and other groundspiders, and, more particularly in northern Queensland, there is a very venomous black and red kind which, like the "katipo" of New Zealand, feigns death when suddenly disturbed, a favourite trick of spiders generally.

The ground-spiders include a number of trap-door builders, as well as others which excavate a trap minus the door. Some spin tough webs of various colours; and one extra careful kind rears its brood in a crumpled leaf ${ }^{1}$ which floats by a span of web out of reach of carnivorous grubs and other foes.

The true Ticks, which are both numerous and troublesome in the scrub, are related to this group.

\section{CENTIPEDES}

Bare mention, too, must suffice for the Myriapoda.

Some of the centipedes grow to a length of twelve inches and inflict a terrible bite.

The chief Australian centipedes are : Scolopendra richardsonii and S. longicornis, Cormocephalus foecundus, C. westwoodii, C. pallipes, C. aurantipes and C. miniatus; Cermatia lesueurii and C. maculata; Henicops maculata, Rhombocephalus brevis, and $R$. politus, and Branchiostoma nuda.

1 Bates, in his Naturalist on the Amazons (Cap. xii.), mentions a larva that suspends its cocoon in similar fashion. 


\section{CRUSTACEANS}

The Crustaceans are not, as an article of food, a great success in Australia. Contrary to the rule in our own waters, their lobsters, mostly small, are inhabitants of fresh-water, while the crayfish are large marine species.

I cannot enter into any details of the life-story of these articulated creatures, of their wondrous development from the mysia or zoëa stage, or their remarkable habit of casting claws and other limbs, about which so much has been said and written. I must also pass over the career of the little isopod parasites already mentioned in connection with their scaly hosts, and the history too of the bisexual barnacle.

An admirable list of Australian crustaceans was compiled many years ago by Mr. Haswell of Sydney, and the only pity is that the Museum trustees did not see their way to add a few good plates. Upwards of five hundred species are described.

Of somewhat novel interest to the visitor are the numerous landcrabs, particularly abundant in the Queensland estuaries, where they scuttle among the roots of the mangroves, making a weird clicking with their large claws. Only the aboriginals eat them. They also enjoy wasp grubs and bugong moths !

The gills of all these land-crabs (of which Gelasimus is the type) are kept continually moist, indeed I have only met with them in the vicinity of swamps where the air is always saturated.

The little Engaus of Tasmania burrows in fresh-water swamps; and there are similar small burrowers up the creeks on the mainland which are excellent eating and equally appreciated by white and black, the former eatching them in baited traps, the latter thrusting their hands deep down into the ooze and dragging the hermits forth between their fingers.

The following are typical species :--

\section{STALK-EYED CRUSTACEANS (Podophthalma).}

1. Brachyurus (Short-tailed).

Scylla serrata (Mangrove Crab).

Stenorkynchus fissifions, a beaked crab with slender legs.

Gelasimus vocans, a swift-running land crab with one claw abnormally large - common in the Fitzroy delta.
Leucosia splendida, a beaked crab with short antennæ; also $L$. orbicularis, $L$. ocellata, and $L$. Whitei.

Myra mamillaris.

Phbyxia lambriformis.

Philyia levis. 
Hyastenus diacanthus.

Paramithrax sternocostulatus.

Nepturus pelagicus (Swimming Crab).

Parthenope horrida, covered, like the

Moloch, with spikes.

Grapsus variegatus, apparently identical with the Painted Crab, and abundant in Queensland estuaries.

Thalamita crucifera.

Calappa hepatica, covered with tubercles.

Myctiris longicarpus, having curious furrows in the shell.

2. Macrures (Long-tailed).

Palinurus hugelii, the common Sydney Cray-fish.

$P$. lalandii, a smaller species from Hobart.

Galathea australiensis, resembling our Plated Lobster.

Tbacus peronii, the Butterfly Lobster of Hobart, allied to the Broad Lobster of our seas.

Astacopsis serratus (Fresh-water Crayfish, N. S. W.)

$A$. bicarinatus, a species from Queens. land rivers.
Penceus canaliculatus (Sand Prawn).

$P$. esculentus.

P. monodon (Tiger Prawn).

Alplieus edvardsib, a clawed Shrimp.

A. socialis ("Nipper Prawn.")

A. franklinii (Tas.)

Crangon australis (Bass' Strait).

Engceus fossor.

Lysiosquilla brazieri.

Gonodactylus clinagra.

Squilla miles.

Palamon ornatus (Fresh-water Prawn).

\section{ANomurus (Tail various lengths).}

Remipes testudinaria ("Oarfoot") with a paddle-like tail.

Dromia excavata, hides in sponges.

Birgus latro.

can live some time out of watershell very spinous.

Ranina dentata (Toothed Frog Crab);

\section{THE GROUND FLOOR}

We are getting lower and yet lower in the scale, and it is with some misgivings that I write finis to this Appendix on the very

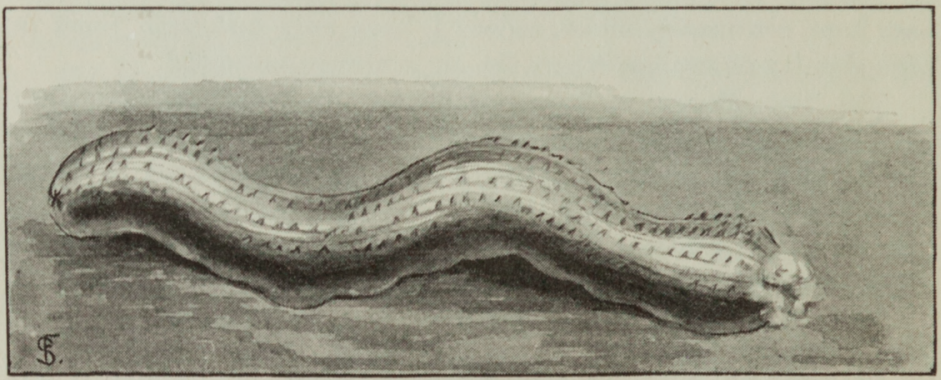

Trepang.

threshold of that vastly-populated realm thronged by Nature's proletariat. It is not in any frivolous spirit that $I$ do not prolong these remarks; not in any want of appreciation of the labours of those gentlemen who devote their lifetime to investigating the false 
feet of foraminifera or the matrimonial conditions of hydrozoa. It is simply from hopeless ignorance of the subject. I find it impossible to discourse profitably of the beautiful Australian Starfishes, ${ }^{1}$ or the hideous black and yellow Leeches (Hirudo, \&c.). The latter have many a time fastened on me in the long grass, going to work so gingerly that the first intimation of their visit would be the blood sticking to my sock after they had dropped off.

Nor has it, out of the museum, been my good fortune to study Australia's gigantic Earthworms (Oligochata, \&c.), such, for instance, as Megascolides australis of Victoria, or the somewhat smaller Notoscolex grandis found near Sydney.

The Sponges and Coral "Insects" also lie somewhat outside my scope; and of the only two creatures on the ground-floor that have some general interest, the Trepang and "Portuguese Man-o'-War," too much has already been written.

The Trepang (Holothuria), alias Sea-Cucumber, Sea-Slug, or Bêchede-Mer, so highly appreciated by Celestial mandarins, is described at length in Savile Kent's splendid work on the Barrier Reef. Allied to the "Cotton-Spinner" of our own waters, these curious and somewhat repulsive creatures are able to vary their length and thickness at will. They are boiled, cleaned, sun-dried, and smoked over a mangrove fire for export to China, only a few of the many known kinds being sufficiently tough to survive the boiling and not dwindle away to liquid.

The graceful and brilliant Physalia megalista, popularly known as the "Guinea Ship" or "Portuguese Man-o'-War," is familiar to voyagers in southern seas. It is one of the Siphonophora (Hydrozoa), and, like other "jelly-fish," or Medusce, it can sting severely. For some reason or other it has been confounded with the Nautilus, to which, however, it bears but slight resemblance. Nor, I fancy, does it possess, as alleged, the power of sinking at will by exhausting the bladder. In the first place, the latter is invariably inflated in specimens cast ashore, by no means of rare occurrence on the coast near Sydney. Moreover, I have repeatedly prodded them with an oar or boathook without their making any attempt at escape. Sea turtles feed very freely on this creature, and often go near being blinded by its stings.

1 I refer, of course, to the Asteroids proper, not to the 0 ctopus, which in that country commonly goes by the name of Starfish. 


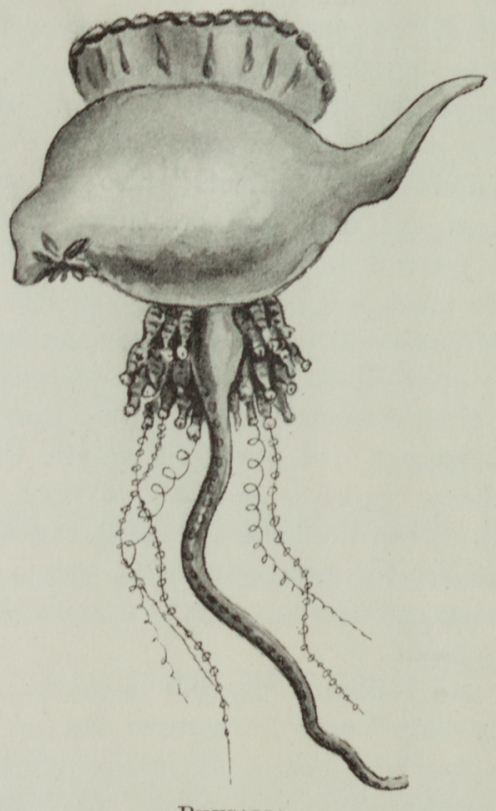

Physalia. 
GLOSSARY 



\section{GLOSSARY}

(The following list contains the majority of obscure words in the foregoing text. The meaning, and not the derivation, is given.)

Acalyptus, unveiled acanthias, prickly acanthogenys, prickly-jawed acanthoglossus, prickly-tongued acanthopis, prickly-snake acanthopterygii, prickly-finned acanthorhynchus, prickly-beaked accipiter, robber

acrobates, walking on tip-toe aculeatus, sharp-pointed

acuminate, pointed adamastor, inflexible adephaga, greedy aderus, short-lived adipose, fatty agialites, shore-haunting agotheles, goat-sucker aëtobatis, eagle-ray affinis, allied agrophilus, fond of the fields aidemosyne, modest ailurcedus, with the voice of a cat albifrons, white-browed albipes, white-footed albiventris, white-bellied albogularis, white-throated alboguttatus, with white spots alcyone, breeding on the sea alopecias, fox-like alsocomus, fond of groves amaurodryas, nymph of darkness ammodytes, burrowing in the sand amphibious,living in two elements amphibolus, doubtful

amphipods, surrounded by feet anabas, climbing

anacanthini, without spines

anatinus, duck-like

anguilliformis, eel-shaped

annulata, ringed

anous, stupid

anseranas, half goose, half duck

antechinus, like a hedghog

aphaniptera, having hidden wings

apicalis, pointed

aprosmictus, solitary

aptenodytes, wingless diver

apteryx, wingless

aquila, eagle

ardea, high-flying

arenaria, frequenting the desert

artamus, hanging, one from the other

aspidiotes, with shields

atopa, out of place

atrichia, smooth-skinned

attagen, snipe

aurita, eared

ausiralis, southern

avicida, killer of birds 
Balistes, like a gun-lock

barbatus, bearded

bêche-de-mer, sea-spade

bicolor, two-coloured

bimaculata, with two spots

bivalve, living in two shells

bolbocerus, bulb-horned

borealis, northern

botaurus, with the voice of a bull

brachyotis, short-eared

brachysoma, short-bodied

brachystoma, short-mouthed

brachyurophis, short snake

brachyurus, short-tailed

branchiostegals, gill-covers

brevicaudus, short-tailed

breviceps, short-headed

brevirostris, short-beaked

bucculentus, small-mouthed

buceros, like an ox-horn

bufo, toad

buprestida, cow-bursters

burhinus, big-nosed

buteo, buzzard

Cacomantis, prophet of ill cacophis, harmful snake calodera, with a beautiful neck calopsitta, beautiful parrot calornis, beantiful bird

calyptorhynchus, with shielded beak campephaga, feeding on caterpil-

lars

campestris, belonging to the plains

canescens, hoary

canina, dog-like

caprimulyus, goat-sucker

carinata, keeled

carnifex, killing

carpophaga, fruit-eating

catarractes, broken

caudacuta, spine-tailed

centropus, spur-footed

cephalopods, with feet growing

from the head

cereopsis, wax-like

certhia, tree-creeper

cery $x$, herald

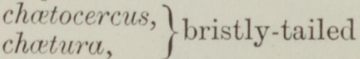

chalcophaps, bronze pigeon charadrius, haunting gullies cheiroptera, with winged hands chelydra, snake-like tortoise chironectes, swimming with hands chondropterygians, cartilaginous fishes chthonicola, earth-lover cinclorhamphus, with barred bill cinclosoma, with barred body cinereus, ashen coleoptera, sheath-winged concinnus, elegant conspicillatus, marked as with

spectacles conurus, cone-tailed coprophilus, dung-loving coronata, crowned coturnix, quail cracticus, noisy crassicaudatus, with bushy tail crassipes, solid-footed crispus, curly crotophaga, eating ticks ctenoid, comb-like cucullata, hooded curtus, short cyanomelas, blue-black cynocephalus, dog-headed

Dasyornis, hairy bird dasyurus, hairy-tailed decapods, with ten feet deciduous, falling off (periodically) dendrolagus, lying in trees dendrophis, tree-snake dentirostris, with toothed beaks dermestes, skin-eater dicrura, double-tailed didelphys, with two wombs didunculus, little dodo dipsa.s, thirst-provoking diptera, with two wings dorsalis, on the back dromaus, dromicia, , swift runner drymophila, wood-lover dyticus, diving

Echidna, viper

echinoderms, with the skin of a hedgehog 
elanus, swift-pouncing

elaps, snake

emydocephalus, tortoise-headed

enhydrina, living in water

entomophila, fond of insects

entozoa, parasites

erythra, red

eucalyptus, giving shelter

euphema, with pleasing voice

Fasciatus, banded

ferrugeneifrons, rusty-faced

flavescens, yellowish

flavipes, yellow-footed

flaviventer, yellow-bellied

foetus, the unborn young

fossor, digger

frenatus, bridled

frontalis, marked on the forehead

fusca, dusky

Gadida, cod family

gasteropods, with feet growing

from the belly

geobasileus, king of the earth

geophaps, ground-dove

gibbous, humped

glaucosoma, with a blue body

gliriformis, like a dormouse

glirinus, ,

glyciphila, fond' of sweet things

griseus, grey

guttatus, spotted

gymnogenys, naked-born

gymnorhina, with naked muzzle

Hcematopus, red.footed

hallucatus, thumbed

halmaturus, jumping with the tail

hapalotis, soft-eared

hemipodus, half-footed

hemirhamphus, half-beak

heteropus, with different feet

himantopus, with thonged feet

hippocrepis, horse-shoed

hirsutus, shaggy

homalopside, smooth

hoplocephalus, with mailed head

hydrophis, water-snake

hymenoptera, with membranous wings
Imbricate, overlapping (like tiles)

inermis, unarmed

inornatus, unadorned

insessores, perching

inustus, unconsumed

Labridce, with lips

lavis, smooth

lagenoplastes, flask-builder

lagorchestes, dancing hare

lagotis, rabbit-eared

lamella, plates

lamprococcyx, glossy cuckoo

laniarius, woolly

laniger, , ,

laniginosus,

larus, gull

larva, mask (insect issuing from the egg)

lasiorhinus, hairy-muzzled

latifrons, broad-faced

lemuroides, nocturnal

lepidoptera, scaly-winged

lepidus, neat

leporoides, hare-like

leucogaster, white-bellied

leucopus, white-footed

leucotis, white-eared

leucura, white-tailed

liasis, swerving

littoral, frequenting the shore

lopholaimus, with tufted throat

lophorhynchus, with tufted bill

luctuosus,
Zugens, mournful, sombre

lunatus, horned

tumulatus, ringed

Macropterus, long-winged

macropus, long-footed

macropygia, large-rumped

macrotis, long-eared

macrourus, long-tailed

maculatus, spotted

magnus, large

major, larger

malacopterygians, soft-finned malacorhynchus, soft-billed mulleus, hammer-head

manatee, with hands

manicatus, gloved 


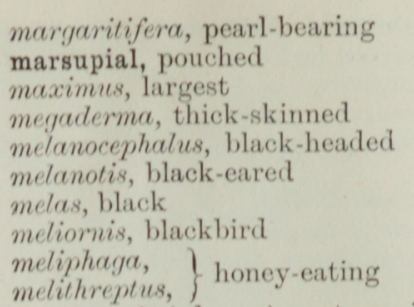

meroblastic (of eggs), part nourish-

ing (i.e., most of the yolk goes

to nourish the fotus)

merops, bee-eater

mesembryanthemum, flower of noon microcarbo, little

microps, small-faced

micropus, with small feet

minimus, smallest

minor, smaller

molluscs, soft creatures

monodon, single-toothed

monotreme, with one outlet

moschatus, musky

murinus, mouse-like

mus, mouse

muscicapa, fly-catcher

mutillida, little flies

myoides, mouse-like

myosurus, with the tail of a mouse

myristicivora, eater of nutmegs

myrmecobius, ant-eater

myzantha, flower-sucker

Nanus, dwarfish

nasuta, long-nosed

nautilus, ship-like

nemadactylus, with fringe-like fins

niger, black

nigrescens, blackish

nigriceps, black-headed

nigrostriatus, with black bands

noctivaga, of nocturnal habits

noctua,

notornis, bird of "the south"

nudicaudatus, with hairless tail

nycticorax, night-crow

Obesula, plump

occidentalis, western

occiput, the back of the head ocellatus, spotted

ochropus, yellow-footed

octhodromus, running along the

shore

octopus, with eight feet

ocyphaps, swift-flying pigeon

odax, biter

olfactory, relating to the sense of smell

olivacea, olive-coloured

onychogalea, claw-tipped

orientalis, eastern

ornithorhynchus, with a bill like a

bird's

omithodelphia, with a womb like

that of birds

orthoptera, straight-winged

osphranter, keen of scent

ossifraga, bone-breaker

oviparous, egg-bearing

ovoviviparous, reproducing by in-

ternally hatched eggs.

Pachycephala, thick-headed pachydermatous, thick-skinned pachyptila, thickly feathered pallidiceps, pale-headed

pardalotus (spotted), like a leopard pelagodroma, running on the sea

pelagicus, marine

pelamis, muddy (snakes)

penicillatus, brush-like, or pencilled

peragale, pouched weasel

perameles, pouched badger

peregrinus, wandering

peristera, dove

petaurus, perching

petrogale, rock-weasel

petrophassa, rock-dove

phalanger, with joined toes

phaps, dove

pharynx, windpipe

phascolarctus, pouched bear phascologale, pouched weasel phascolomys, pouched mouse physostomi, with open air-bladder piezorhynchus, with flattened beak pimelepterus, with fat wings

placental, in which the foetus has blood-connection with the mother 
platurus, broad-tailed

platycephalus, broad-headed

platycercus, broad-tailed

platyops, broad-faced

platypus, broad-footed

platyrhinus, broad-nosed

plectognathi, with twisted jaws

plectorhyncha, with twisted bill

pleuronectida, side-swimmers

plexus, a network

plicate, in folds

podabrus, with smooth feet

podiceps, with feet behind the

rump

poëphila, loving grass

polygrammicus, marked with many

lines

porphyriaca, purple

procellaria, storm-bird

psammophis, sand-snake

psephotus, black-eared

pseudechis, like a viper

pseudochirus, false hands

psilopus, bare-footed

psophodes, shrill-voiced

ptilosclera, much feathered

ptilotis, with feathery ears

punctulatus, dotted

pusillus, small

pygmaens, dwarfish

Recurvirostra, with bill turned

backwards

reticulata, net-like

rhynchaspis, with shielded beak

rostratus, beaked

rufescens, reddish

rificollis, with red neck

$\left.\begin{array}{l}\text { rufiventer, } \\ \text { rifogaster, }\end{array}\right\}$ with red belly

rufogrisens, reddish-grey

rifus, red
Saltator, jumping

sarcophilus, fond of flesh

saxicola, frequenting the rocks

sciureus, squirrel-like

sclerolepis, hard-scaled

scomber, mackerel

scomberesox, mackerel-pike

scutatus, shielded

scythrops, gloomy

sericomis, glossy bird

setiform, bristle-like

setosus, bristly

signatus, marked

sphecotheres, eater of wasps

spilotes, stained

Tachyglossus, swift.tongued

tachypetes, swift-flying

thalassidroma, running on the sea

thylacinus, pouched dog

thylacoleo, pouched lion

thylogale, pouched weasel

trichosurus, hairy-tailed

trichoglossus, brush-tongued

tridactylus, three-fingered

trivirgata, with three stripes

typhlops, blind

Unguifer, nailed

unistriatus, with one band

univalve, living in one shell

ursinus, bear-like

Viverra, ferret

viviparous, giving birth to young volans, flying

vulpecula, fox-like

Xanthopus, yellow-footed

xenorhynchus, with strange beak

Zosterops, with belted face 

INDEX 



\section{INDEX}

A

Abdominal Plates of Snakes, 163 Ablepharus, 185

Aboriginals, 4, 5, 7, 43, 49, 78, 81, 121, 132, 134 f.n., 137, 145, 152, 264,277

Abrolhos, 93, 226

Acalyptus, 176

A canthophis, 169

A canthopterygii, 219

A canthorhynchus, 120

Acrobates, 57

Adelaide, 61, 121, 125, 262

Adjutant, 110

Aegialites, 103

Aegintha, 138

Aelurosaurus, 180

A epyprymnus, 47

Agamida, 177

Agamis, 157, 181

Aguara, 7

Aiturcedus, 134

Aipysurus, 175

Alarm Bird, 103

Albany Island, 120

Pass, 94, 261

Albatross, 89

Alcyone, 114

Allied Harrier, 145

Kite, 144

Rat, 10

Alligators, 186

Alpaca, 82
Amaurodryas, 141

America, South, 7, 151, 160, 215

Amytis, 156

Anarhynchus, 88

Anas, 100

Anatida, 98

Anellobia, 118

Angling, 201-212

Anomurus, 278

Anous, 93

Anseranas, 99

Ant-eater, 79

Antechinus, 28, 69

Antennarius, 228

Anthochoera, 118

Ant-lions, 273

Ants, 269

A pate, 271

A prasia, 179

Aprasiida, 177

Aptenodyx, 96

Apteryx, 88

Aquarium, Melbourne, 225

Aquila, 143

Arapaima, 216

Arapunga, 120 f.n.

Arctocephalus, 24

Ardeida, 101

Ardemosyne, 138

Ardetta, 102

Argonaut, 261

Ariel, 56

Arripis, 198

Aspidiotes, 167 
Auks, 98

Aulopus, 243

Austral Eel, 246

Avocet, 103

B

Bait, 204, 207, 209, 211

Baleen, 21

Banded Ant-eater, 70 Collared Snake, 173

Wallaby, 44

Bandicoot, 63

Banksian Cockatoo, 124

Barbary Ape, 6

Barn Owl, 146

Barracouta, 230 f.n., 234

Barramunda, 145, 199, 211

Barred-Shouldered Dove, 150

Barrier Reef, Great, 17, 94, 239, 260

Barton (quoted), 27, 114

Basking Shark, 221

Bass' Strait, 91, 98, 99, 128

Bastard Dory, 225

Batavia, 122, 162

Batchian, 138

Bates (quoted), 276 f.n.

Batfish, 232

Bathilda, 138

Batrachians, 191

Bats, 13, 31, 67

Baudin's Cockatoo, 124

Beach Fishing, 210

Bear, Native, 48, 51

$$
\text { Sea, } 24
$$

Sun, 54

Beardie, 197, 240

Beaver Rats, 11

Bees, 264

Beetles, 269

Bell Bird, 120

Belone, 243

Bennett (quoted), 13, 22, 54, 76, $77,81,89,94,107,108,125,131$

Berley, 207

Bernicla, 108 f.n.

Beryx 199,252

Bettong, 28, 44

Bil-bil, 145
Bill of Platypus, 75, 77

Birds, 87-154

Bismarck Archipelago, 107

Bittern, 101

Biziura, 100

Black Ants, 268

-backed Snake, 173

-bellied Snake, 172

Bream, 207, 226

Cockatoo, 124

-eared Cuckoo, 135

Eimu, 107

Fantail, 139

Fish, 200, 214, 227

Grouse, 129

-headed Honey-eater, 118

-headed Snake, 167

Magpie, 140

-naped Snake, 173

Opossum, 51

Robin, 141

Rock Cod, 224

Snake, 168, 169, 170

Swan, 98

-throated Magpie, 140

Blind Snakes, 167

"Bloodsucker," 178

Blubber, 7

Blue Eye, 119

Groper, 209, 237

Hawk, 145

Mountains, 144

Parrot, 125

Pointer, 206, 222

Wren, 136

Boatswain-bird, 94

Bombyces, 263

Bondi, 175

Bones, Marsupial, 28, 67, 74

Bony Salmon, 242

Boo, 63

Boobies, 96

Boobook Owl, 127, 146

"Boomer," 35, 40

Boomerang, 121

Boongarry, 43

Borschgrevink, 22

Bourke, 126

Bower-builders, 132, 150

Brachysoma, 173 
Brachyurus, 277

Brain of Marsupials, 38

Seals, 38

Breams, 225, 250

Brisbane, 10, 19, 122, 209

Broad-headed Snake, 172

," Wombat, 6

Bronze Cuckoo, 117, 135

Bronzewings, 149

Brown-banded Snake, 169, 171

Flycatcher, 139

Hawk, 145

Honey-eater, 118

Owl, 146

Rat, 8

Snake, 168, 172

Tree-snake, 168

Bruchigavia, 93

Bruchus, 272

Brush-tailed Opossum, 51

Turkey, 153, 154

Wallaby, 40

Buffaloes, 82

Buff-footed Rat, 10

Bufo, 191

Bugong, 262 f.n.

Bugs, 274

Buitenzorg, 110

Bujerigar, 125, 126

Bullan-bullan, 132

Bulli, 132

Bull-rout, 228

Bumboras, 223

Bunya, 42

"Bunyip," 83

Buprestida, 271

Burbot, 240

Burnett River, 146, 216

Bush Kingfisher, 116

Bustard, 108

Butcher Birds, 114, 140

Buteo, 145

Butoroides, 102

Butterflies, 262

Buzzard, 145

Byrne (quoted), 169

\section{C}

Cacatua, 122

Cacophis, 168, 173
Caddis, 274

Cairns, 138, 221, 229

Calaptorhynchus, 124

Caldwell, 77, 80

Callocephalon, 124

Caloprymnus, 47

Camels, 82

Canary Parrot, 125

Cantharida, 271

Cape Barron Goose, 99 Island, 91

Cape York Peninsula, 116, 117, $124,128,192$

Caprimulgida, 127

Caraduck, 110

Carangidoe, 251

Carcharodon, 223

Carinated Flycatcher, 139

Carpet Shark, 221 Snake, 160, 165

Carphibis, 103

Caspian Tern, 93

Cassowary, 107

Castelnau (quoted), 212, 233

Casuarius, 107

Cat Bird, 134

Caterpillars, 6

Cat Fish, 39, 214, 241

Catodon, 221

Cattle, 82

Centipedes, 276

Centropogon, 228

Centropus, 135

Cephalopods, 260

Ceram, 108

Ceratodus, 146, 197, 215

Cerberus, 174

Cereopsis, 99

Cestracion, 221

Charopus, 63

Chatodontide, 205, 218, 252

Chotura, 128

Channel Bill, 135

Chatossus, 198, 215

Chelemys, 188

Chelodina, 188

Chelonia, 188

Chelonians, 188

Chenopis, 98

Cheramaca, 128 
Cherry Picker, 118

Chestnut-bellied Rail, 102

Chilodactylus, 236

Chirocentrus, 211

Chiroleptes, 193

Chironemus, 236

Chlamydera, 134

Chlamydochen, 100

Chlamydosaurus, 179

Chondropterygii, 219

Choriotis, 109

Chrysidida, 267

Chrysocoma, 98

Cinclosoma, 135

Clarence River, 173

Cleveland Bay, 99, 143

Climacteres, 116, 138

Clupea, 198

Clupeida, 198, 253

Coach-Whip Bird, 132

Cobra, 168

Coburg Peninsula, 15

Cockatoos, 5, 121, 123, 124

Cocoanut Crabs, 43 f.n.

Cod, Black Rock, 197 f.n.

Murray, 197 f.n.

Red Rock, 197 f.n., 227

Codlin Moth, 264

Coffer Fishes, 247

Coghlan (quoted), 104

Cohen (quoted), 198 f.n. 199, 200, $204,212,224$

Coleoptera, 272

Collins (quoted), 24

Colombo, 122, 162

Columbida, 150

Conger, 246

Coogee, 175, 247

Cooktown, 43, 212

Copidoglanus, 214

Copper Head, 171

Coral Fishes, 205

Corals, 279

Cormorants, 95

Coronella, 167

Corpus callosum, 74

Corrill, 10

Corroboree-places, 132

Corvina, 211

Coturnix, 150
Coucals, 135

Cow Bird, 135

Cowry, 258

Crabs, Land, 39, 277

Cracticus, 140

Crambi, 264

Cranes, 110

Craspedophora, 137

Crayfish, 277

Crested Parrakeet, 125 Penguin, 98

Crickets, 273

Crimson-winged Lory, 87

Crinia, 193

Crocodile Fishes, 237

Crocodiles, 186

Crocoditus, 187

Crowned Snake, 172

Crow-Shrikes, 140

Crustaceans, 277

Cryptodelma, 181

Cuckoo Owl, 146

Cuckoos, 135

Cuculus, 135

Cucumber, Sea, 279

Mullet, 215

" Cungevoi," 209

Cunningham (quoted), 29

Curassows, 151

Cuscus, 57, 68

Cyanalcyon, 116

Cypara, 258

Cypselus, 128

D

Dacelo, 114

Dactylopsila, 54

Darter, 96

Dasyures, 65, 68

Death-Adder, 160, 168, 169

Delma, 181

Demiegretta, 101

Dendrocygna, 100

Dendrolagus, 42

Dendrophis, 168

Dermestida, 270

Derwent, 142

Devil, Tasmanian, 5, 41, 65, 67

Diamond Birds, 137 
Diamond Snake, 157, 160, 165, 171

Dicoerm, 120

Dicrurus, 129

Didelphys, 50

Diemenia, 168 f.n., 172

Dilbong, 120

Dingo, 3,9

Diomedea, 89

Diplodactyius, 180

Dipnoi, 215

Diporophora, 182

Diprodonts, 35

Dipsas, 168

Disteira, 175

Diving Petrel, 91

Dogs, 5, 6, 7, 42

Dolphins, 20

Donacola, 138

Dorab, 211

Dottrel, 103

Doves, 150

Dragon-Flies, 273

Drive, Wallaby, 5, 41

Dromains, 104

Dromicice, 57

Drummer, 227

Drymodes, 141

Duck-bill, 75

Duck-mole, 75

Ducks, 100

Dugong, 3, 17, 18

Dung Beetles, 270

Dusky Robin, 141

E

Eagle Hawks, 143

Eagles, 142

Eared Owls, 146 Seals, 24

Earthworms, 279

Earwigs, 273

Echidna, 79

Eel Pout, 240

Eels, 107, 198, 246

Egernia, 182

Eggs of Echidna, 80 Emu, 107

Mutton Bird, 92
Eggs of Native Companion, 110 Platypus, 77

Pythons, 165

Tortoises, 77

Elapidae, 168

Elephant, Sea, 24 Fish, 224

Elseya, 188

Emblema, 138

Emu, 104

Wren, 136

Emydocephalus, 175

Engoeus, 277

Entomyza, 119

Eopsaltria, 141

Ephippiorhynchus, 112

Erythrogenys, 103

Eschricht (quoted), 22

Eudynamis, 135

Eudyptes, 98

Eudyptula, 98

Euphema, 125, 126

Eurostopodus, 127

Exfalcatoria, 151

Exocetus, 245

\section{F}

Fairy Martins, 128, 132 Penguin, 97

Falcons, 145

Fawn-breasted Bower-bird, 134

Feet of Antechinus, 70

Echidna, 81

Hypsiprymnodon, 47

Kangaroo, 36

Owls, 146

Platypus, 75

Queensland Dasyure, 69

Fer-de-lance, 160

Fiddle-fish, 224

Finches, 138

Fire-tail, 138

Fisheries, 200, 248

Fishes, 197-254

Fish Hawk, 142, 144

Fishing, 201-212

Fitzroy Island, 14

River, 146, 174, 175, 199, 210 
Flatfish, 199, 238, 253

Flatheads, 205, 206, 207, 208, 236, 252

Flat-tailed Mullet, 232

Fleas, 274

Flounders, 199, 239

Flycatchers, 139

Flying Fish, 244 Fox, 13, 53

Mice, 57

Phalangers, 41

Squirrels, 27, 48, 54

Foraminifera, 279

"Forester," 35

Fortescue, 206, 228

"Forty Spot," 137

Fossils, 31, 178 f.n., 191 f.n.

Freshwater Fishes, 213

Herrings, 198, 215

Friar Birds, 119

Frigate Bird, 94

Frilled Lizard, 179

Frog Fish, 228

Frogs, 162, 191

Frost Fish, 234

Fruit Pigeons, 53, 147

\section{G}

Gadida, 197, 198, 238 f.n., 253

Gadopsis, 214, 238 f.n.

Galapagos, 13

Galaxias, 215

Galeocerdo, 221

Gall Flies, 268

Gang-gang, 124

Gannet, 94, 96

Ganoids, 215, 218

Gar Fish, 218, 243

Garrulous Honey-eater, 120

Gavial, 187

Geckoes, 178, 179, 180

Geckonide, 177

Gehyra, 180

Gelasimus, 277

Genyoroge, 225

Geopelia, 150

Geophaps, 149

Geotria, 248
Gerres, 225

Giant Herring, 242

Perch, 146, 199, 210, 214

Petrel, 91

Gilbert (quoted), 9, 148

Gill Bird, 118

Girella, 200, 227

Glareola, 103

Glenodium, 260

Glowworms, 271

Goatsucker, 126

Gobies, 217, 248

Godwit, 103

Golden Moles, 72

Gonyocephalus, 181

Goose, Cape Barron, 99

Grey, 100

Magpie or Semi-palmated, 99

Goshawks, 144

Goulburn, 59

Gould (quoted), 9, 11, 15, 30, 90, $100,102,118,121,128,132,137$. $143,145,148,151$

Gourami, 216

Government Bream, 225

Grallatores, 101, 103

Grammatophora, 177 f.n., 179

Grass Finches, 138

Flatheads, 237

Parrakeets, 122, 125

Grauculi, 140

Grayling, 215

Great Bower-bird, 134

Bustard, 109

Greater Cuckoo, 135

Great Stone Plover, 103

Grebes, 93

Greene (quoted), 122

Green Bone, 243

Eel, 246

Parrot, 125

Tree Snake, 168

Grey Falcon, 145

Shrike, 140

Wood Swallow, 129

Grinder, 139

Groper, Blue, 209, 237

Red, 238

River, 214

Ground Dove, 135 
Ground Duck, 88

Parrots, 88, 123

Snake, 167

Thrushes, 136

Grus, 109

Guba, 140

Guillemot, 98

Gulls, 89, 92

Gurnards, 211, 236, 243

Guttated Bower-bird, 134

Gymnobelideus, 56

Gymnodactylus, 180

Gymnophthalmada, 177

Gymnorhina, 140

\section{$\mathrm{H}$}

Hairy Wombat, 61

Haku, 231

Haladroma, 91

Haliatus, 142

Haliastur, 142

Halibut, 199

Halicore, 17

Halmaturus, 45

Hamadryad, 164, 165, 168

Hammerhead, 223

Hapalotis, 9

Hapuku, 214

Hard Gut Mullet, 232

Hare Wallaby, 43, 44

Harriers, 145

Hawkesbury, 95, 207, 233

Hawks, 144

Hedgehog, 80

Heloderma, 178 f.n.

Hemisphariodon, 183

Hepialis, 263 f.n.

Hepoona, 56

Herbert River, 43, 70

Heron, 101

Herrings, 198, 241

Heterodontus, 221

Hetoronata, 180

Heteroptera, 274

Hieracidea, 145

Himantopus, 103

Hippocampus, 247

Hirudo, 279

Hirundo, 128
Hobart, 121, 143, 199, 228, 23!, 236,238

Hobson's Bay, 198 f.n.

Holothuria, 280

Homalopsince, 174

Honey, Native, 264 Eaters, 117, 135

Hopley (quoted), 157, 161

Hoplocephatus, 160 f.n., 171

Horse Mackerel, 229, 230

Horses, wild, 82

Horseshoe Bats, 14

Hudson (quoted), 7, 27

Humboldt (quoted), 122

Humming Birds, 132

Hunting, 41

Hyæna, 66

Hydrochelidon, 93

Hydromys, 8

Hydrophiina, 174

Hydrophis, 175

Hyla, 192, 193

Hylidoe, 191

Hyperolia, 193

Hypsiprymnodon, 36

Hypsiprymnus, 44

Ibis, 103

I

Iceland, 13

Ichneumonida, 268

Iguana, 177, 179

Illawarra, 119, 131

Illiger, 17

Imperial Institute, 61

Insects, 261

Insessores, 113

Jabiru, 109

Jacanas, 112

Jackass, 114, 236

"Jack Hurry," 93

Jardine's Harrier, 145

Javelin Fish, 225

Jelly Fish, 279

Jew-Fish, 207, 208, 233

Lizard, 157, 179

Julodimorpha, 271

Jungle-Fowl, 153, 154 


\section{K}

Kalongs, 13

Kangaroo, 28, 32, 39

Kaup (quoted), 145

Kea, 88, 122

Kelp Fish, 238

Kent (see Saville Kent)

Keppel Bay, 9, 211, 259, 276

King Fish, 200, 230, 233

Kingfishers, 113, 150

Parrot, 87

Penguins, 96

Kites, 144

Knot, 103

Koala, 29, 36, 41, 48, 51, 57

Kogra, 79

Kookaburra, 114

Krefft (quoted), 159, 168, 169, 171, 177 f.n., 192

\section{L}

Labrida, 237

Lace Lizard, 179

Lady-Birds, 272

Lagenoplastes, 128

Lagorchestes, 43

Lagostrophus, 44

Lake Eyre, 72

George, 83

Macquarie, 227

Lamna, 222

Lampreys, 248

Lamprococcy $x, 135$

Land Crabs, 39, 277

Large-scaled Snake, 169, 171

Larida, 92

Latham, 154

Lathamus, 126

Latris, 199, 235

Laughing Jackass, 114, 164

Leadbeter's Cockatoo, 123

Leaf Insect, 273

Leatherheads, 119 Jackets, 205, 246

Leathery Turtles, 188

Leeches, 279

Leichardt Tree, 108

Leipoa, 152, 154

Leopard, Sea, 24

Lepidopus, 234
Lepidosiren, 215

Leptonyx, 24

Lesser Cuckoo, 135

Leucomelana, 149

Leucosarcia, 148

Lialida, 177

Lialis, 179

Liasis, 167

Limnodynastes, 192

Limosa, 103

Limpet, 259

Lindsay Thomson (quoted), 198f.n.

Ling, 197, 240

Lions, Ant, 273

Little Turtle-Dove, 150

Liverpool Range, 138

Lizards, 177-185

Lobivanellus, 103

Lobsters, 277, 278

Locusts, 273

Lofoden, 197

Loggerhead, 188

Loligo, 261

Long-eared Bats, 14 -snouted Phalanges, 57

Tom, 243

Longicorns, 272

Lophius, 228

Lopholaimus, 147

Lophorhombus, 239

Lories, 124

Lorikeets, 126

Lotella, 197

Lumholtz (quoted), 43, 70, 80, 88, 216

Lung Fishes, 215, 216

Lydekker (quoted), 6, 31, 40, 72

Lygosoma, 183

Lyre-Birds, 129, 150

\section{M}

Mackay river, 146, 214

Mackerels, 229, 251

Macleay, 22

Macquarie Island, 96 Lake, 227

Macrocephalus, 21

Macropods, 32

Macropygia, 150 
Macrurus, 278

Magpie, 140 Goose, 99 Perch, 236

Maigre, 208, 211, 233

Malacorhynchus, 100

Malay Archipelago, 14, 54, 129

Mallangong, 75

Mallee Hen, 152, 154 Snake, 169

Maluri, 136

Mammals, 3-83

Manatee, 17

Mangrove Bittern, 102 Crab, 277

Mangroves, 259

Manorhina, 120

Mantis, 273

Maori-jig, 234

,. Rat, 8

Maoris, 91, 231

Maray, 241

Marsh Harrier, 145

,, Tern, 93

Marsupials, 26-72

Mary river, 146, 216

Mastodon, 19

Mealworm, 271 f.n.

Meckel (quoted), 80

Megaderma, 14

Megaloprepia, 149

Megalops, 242

Megapodes, $133,147,150$

Megapodius, 153, 154

Melanodryas, 141

Melbourne, 145, 225, 230 f.n., $233,238,240$

Meleagrina, 260

Meliornis, 119

Meliphagide, 117

Melopsittacus, 125

Menura, 129

"Merry thought," 74

Mesocalius, 135

Mice, Pouched, 28, 69

Microca, 139

Microglossum, 124

Milvus, 143, 144

Mimeta, 135

Mindai, 83
Miner, 120

Minute Bittern, 102

Mitchell (quoted), 64, 106

Mitres, 258

Mixophyes, 192

Moa, 19

Mock Regent Bird, 119

Mole, 28, 70

Molluses, 258

Molly Hawks, 89

Moloch, 178

Molossus, 14

Moluceas, 124

Monarcha, 139

Mongoose, 164

Monitor Lizards, 164

Monocanthus, 246

Monorebia, 265

Monotremes, 26, 73

Moor Hen, 102

Mooruk, 108

Mordacia, 248

Morelia, 157, 165

Moreporks, 127

Moreton Bay, 103

Morning Dawn, 258

Morunga, 24

Morwong, 205, 236

Mosquitoes, 274

"Mother Carey's Chickens," 90

Moths, 262

Mound Builders, 150, 151

Mountain Thrush, 136 Trouts, 215

Mud Hoppers, 211 f.n., 248

Mugil, 232 f.n.

Mulbenger, 57

Mullets, 232, 251

Murana, 246, 253

Muranesox, 246

Murex, 258

Murray (quoted), 8, 35

Murray Cod, 197, 213

Perch, 214

Mus, 9, 10

Muscicapida, 137

Museums, 10, 19, 22, 47, 77, 80, $143,146,152,168,262,273$

Musk Duck, 100

Musky Lorikeet, 126 
Mussels, 258

Mutillida, 266

Mutton Bird, 91, 150

,, Fish, 259

Myiagra, $139 \mathrm{f} . \mathrm{n}$.

Myliobatis, 250

Myobatrachus, 192

Myriapoda, 276

Myristicivora, 148

Myrmecobius, 28, 29, 65, 72

Myrmeleontide, 273

Myxus, 232

Myzantha, 120

\section{$\mathrm{N}$}

Nail-tailed Wallaby, 43

Nankeen Heron, 101

Nannygai, 199, 205, 235

Nardoa, 167

Narrabeen Lakes, 15

Natatores, 89

Native Companion, 110

Hen, 102

Pheasant, 152, 154

Sparrow, 138

Naultinus, 158

Nautilus, 261

Nectarinia, 120

Nectris, 91

Neochanna, 215

Nephrurus, 180

Nets, 98, 198

Nevroptera, 273

Newfoundland, 197

New Guinea, 27, 42, 51, 57, 63, $68,69,80,108,116,129,137$, 151,172

New Holland Darter, 96

$$
\text { ,, ,, Vulture, 154 }
$$

New South Wales, $11,15,53,68$, $100,101,104,116,118,119,120$, $124,125,126,130,132,135,137$, $138,139,140,141,148,154,165$, $168,169,172,173,201,209,212$, 241

New Zealand, 8, 82, 88, 98, 122, 127 f.n., 142, 158,198 f.n., 201, $214,215,226,234,236,239,243$, 262,276
Nicol (quoted), 17

Night Heron, 101

Nightjar, 126, 129

Noctua, 263

Noddies, 93

Notaden, 192

Notidanus, 223

Notornis, 88

Notoryctes, 72

Nott (quoted), 67 f.n.

Nurses, 206

Nycticorax, 101

Nyctophilus, 14

Nymphicus, 125

\section{$\mathrm{O}$}

Octopus, 260

Ocydromus, 88

Ocyphaps, 149

Odax, 198, 238

Oedicnemus, 103

Oedura, 180

Ogilby (quoted), 64, 212

Oil, Dugong, 19 Emu, 106

Shark, 224

Sperm, 23

Oldfield, Thomas (quoted), 38

old Wife, 224

Oligorts, 197 f.n., 199, 210, 213, 214

"On the Wallaby," 50

Onychogalea, 43

Onychoprion, 93

Opkiopsiseps, 185

Opossum Mouse, 57

Opossums, Black, 51

Brush-tailed, 51

Ring-tailed, 51

Short-eared, 51

Oreoïca, 120 f.n.

Orioles, 132, 135

Ornithorhynchus, 75

Orthagoriscus, 247

Osphranter, 45

Osprey, 144

Ossifraga, 91

Osteoglossum, 216

Ostracion, 247 
Ostrich, 104

Oven Bird, 132

Owen (quoted), 30, 77

Owls, 146

Ox Eye, 242

Oysters, 259

Pacific Ocean, 202

Pagrus, 199

Painted Finches, 138

Quail, 150

Pale-headed Snake, 172

Palmer, 146, 214

Pandion, 144

Pardalotus, 137

Pariah, 7

Parrakeets, 121, 124

Parrot Fish, 238

Parrots, 121, 124

Partridge Bronzewing, 149

Peacock, 164

Pearls, 260

Pegasus, 247

Pelamis, 175

Pelican, 94, 95

Penguin, 96

Pentaroge, 228

Peragale, 63

Perameles, 63

Perches, 213, 217, 250

Perching Birds, 113

Pergide, 268

Periophthalmus, 248

Perth, 14

Petaurus, 54

Pete, 179

Petrels, 90

Petrogale, 42

Petroïca, 140

Petrophassa, 150

Phaëton, 94

Phalacrocorax, 95

Phalangers, 50

Phalangiste, 48

Phaps, 149

Phascolarctus, 51

Phascologale, 69

Phascolomys, 59
Phasma, 273

"Pheasant," 131

Native, 152

Shell, 259

Philippines, 123, 151, 153, 154

Phyllopteryx, 247

Physalia, 280

Physignathus, 177, 182

Pied Crow Shrike, 140

Piezorhynchus, 139

Pigeons, 147

Pig Fish, 205, 238

Pike, Sea, 205, 234 Eel, 246

Pilchard, 198 f.n., 241

Pilot Fish, 229

Pink-eyed Duck, 100

Piper, 243

Piping Crows, 140

Pipistrelle, 15

Pitta, 136

Placentals, 3

Playyodus, 243

Plain Finch, 138

Platuri, 174

Platurus, 175

Platycerci, 124

Platypus, 75

"Playing 'possum," 50

Plectognathi, 246

Plectropoma, 200

Pletholax, 181

Pleuronectida, 199, 239

Plotus, 96

Plovers, 103

Podargus, 127

Podicipida, 93

Poditti, 116

Pecilodryas, 141

Poëphila, 138

Polynemus, 212 f.n.

Pomatorhinus, 119, 136

Poor Soldier, 119

Porcupine Fish, 247

Porpoise, 20

Port Alma, 211

,, Essington, 9, 10

, Jackson, 90, 202, 224, 229, $231,239,247,274$

, Shark, 215, 221 
Port Lincoln, 172

Phillip, 89

Stephen, 260

"Portuguese Man of War," 261 f.n., 280

Potoroo, 44

Pouch bones, 28

Pouched Lamprey, 248

Mice, 28, 69

Mole, 28, 72

Rats, 8

Pratincoles, 103

Prawns, 278

Praying Mantis, 273

Prey, beasts of, 65 birds of, 142

Prionodura, 134

Prions, 91, 272

Pristiophorus, 223

Pristis, 223

Procelsterna, 93

Protopterus, 215

Prototroctes, 215

Psettodes, 239

Pseudechis, 170

Pseudochirus, 51

Pseudonaja, 173

Pseudophryne, 193

Pseudopus, 178

Pseudorhombus, 239

Psophodes, 132

Ptilorhis, 137

Ptilorhynchus, 134

Ptilosclera, 126

Ptilotis, 118

Ptinida, 271

Ptistes, 124

Puffin, 98

Pygopodida, 177, 181

Pygopus, 178

Pyrales, 263

Pythons, 159, 165

Quails, 150

Quatawur, 117

Queensland, 9, 10, 39, 42, 51, 53, 54, $57,69,70,82,96,102,107,114$, $116,117,118,119,125,126,133$, $134,135,137,139,140,143,145$,
$149,150,154,167,168,171,173$, $174,177,192,197,199,210,212$, $216,247,248,277$

$\mathrm{R}$

Rabbit Rat, 9, 63

Rabbits, 5, 82, 83

Radius, 259

Rails, 102

Ramsay (quoted), 108, 152

Rana, 191, 192

Raptores, 142

Rasores, 146

Rat Kangaroo, 35, 44

Rats, 9, 10

Rays, 223, 250

Recurvirostra, 103

Red-backed Kingfisher, 117 Bill, 138

-breast, 140

-capped Robin, 141

-collared Lorikeet, 126

-fronted Fantail, 139

Groper, 238

Gurnard, 243

-kneed Dottrel, 103

-legged Gannet, 96

Rock Cod, 227

Sea, 17

-tailed Black Cockatoo, 124

Reduplication in native dialects, 132 f.n.

Reef Heron, 101

Regent Bird, 135

Remora, 230

Reptiles, 157-194

Rhea, 104

Rhidipura, 139

Rhinodon, 221

Rhinolophus, 14

Rhynchoedura, 180

Rhytina, 18

Rifle Birds, 137

Right Whale, 21

Ringed Snake, 173

Ring-tailed Opossum, 51

River Groper, 214

Riverina, 169 f.n.

River Tortoise, 188 
Robins, 140

Rockhampton, 109

Rock Cod, 227 Flatheads, 237

Snakes, 167

Wallaby, 40

Whitings, 238

Rodents, 8, 31

Rose-breasted Cockatoo, 123

Rosehills, 125

Rosella, 125

Rove Beetles, 270

Ruby Fish, 228

Tails, 267

" Running Joey," 37

\section{S}

Sacred Kingfisher, 116

Saddle Bill, 112

St. Helena, 13

St. Hilaire (quoted), 11, 80

Salmon, 198, 200, 210

Salmonidæ, 216, 218

Samson Fish, 200, 231

Sand Martin, 128

Mullet, 232

Pipers, 103

Wasps, 265

Whitings, 199, 237

Sarcophitus, 67

"Sardines," 198, 215

Satin Bower-bird, 134

Sauloprocta, 139

Saville Kent (quoted), 148, 179, $198,212,239,260$

Saw Fish, 22

Scad, 230

Scalaria, 258

Scaly-breasted Lorikeet, 126

Scarabs, 270

Scarlet-spotted Snake, 173

Schlegel (quoted), 167, 176

Schnapper, 199, 202, 211, 225, 235 f.n.

Sciana, 252

Scincida, 177

Scoliadae, 267

Scombresocida, 243, 254

Scopelida, 253
Scorpana, 197 f.n.

Scorpions, 276

Seratching Birds, 147

Scotophilus, 15

Scrub Robins, 141

,W Wallaby, 40

Scythrops, 135

Sea Bear, 24

Birds, 89

Butterfly, 21

Eagles, 142

Fish, 219

Garfish, 243

Horses, 247

Leopard, 25

Mullet, 232

Pike, 205, 234

Scorpions, 251

Snakes, 174

Seals, 24, 38

Secretary Bird, 164

Semi-palmated Goose, 99

Sergeant Baker, 205, 228, 242

Sericulus, 135

Seriola, 200

Serranus, 197 f.n.

"Settler's Clock," 114

Seven-gilled Shark, 223

Sewin, 198

Shag, 95

Sharks, 39, 220, 249

Sheep, 82

Shell Fish, 253

Parrot, 125

Shining Flycatcher, 139

Shooting, 40, 41, 48

Short-beaked Garfish, 243

Shoveller, 100

Shrikes, 140

Shrike-thrushes, 140 -tits, 140

Sillago, 198, 199

Silphide, 270

Silurida, 218, 254

Silver Belly, 241

-crowned Honey Eater, 119

Fish, 261, 274

Jew, 233

Singing Honey Eater, 118

Sirenia, 17 
Sitella, 136

Skinks, 179, 182

Skins, 27, 56

Skipjack, 211 f.n.

Skud, 93

Sminthopsis, 69

Smutty Parrot, 125

Snake Bird, 96

Snake-bite, 163

Snakes, 159, 176

Snipe, 103

Solan Goose, 96

Sole, 199, 239

Sooty Tern, 93

Water Rat, 11

Sordid Kingfisher, 117

South America, 7, 151, 160

South Australia, 9, 10, 11, 53, $100,158,168,172,179$ f.n., 248

Spanish Fly, 271

Sparrow Hawk, 145

Spatula, 100

Speckled Teal, 100

Spencer Cobbold (quoted), 64

Sperm Whale, 21

Sphargis, 188

Spheniscida, 96

Sphyrana, 254

Spiders, 276

Spine Bill, 120 -tailed Swift, 128

Spor.ges, 279

Spoony, 100

Spotted Bower-bird, 134

,, Cuscus, 57

,, Diamond Bird, 137

,, Emu, 107

, Nightjar, 127

Spur of Echidna, 74, 81

,, ,, Platypus, 86

Spur Wing, 103

Square-tailed Kite, 144

Squeaker, 140

Squid, 261

Squirrel Petaurus, 56

Stalking, 39

Star Fishes, 279

Starlings, 129

Steller's Sea-Cow, 18

Stenorhynchus, 24

Stercorarius, 93
Sterna, 93

Stick Insect, 273

Stigmatops, 118

Stigmodera, 271

Stilt, 103

Stingray, 224

"Stinkpot," 90

Stipiturus, 136

Stock-Whip Bird, 139

Stradling (quoted), 157, 161

Stranger, 238

Straw-coloured Ibis, 103

Strepera, 140

Strepsilas, 103

Strigida, 146

Striped Phalanger, 54

Strix, 146

Struthious Birds, 104

Stubble Quail, 150

Stump-tailed Lizard, 178

Sula, 96

Sulphur-crested Cockatoo, 122,123

Sun Bears, 54

Bird, 120

Fish, 247

Sunghong, 248

Superb Warbler, 136

Swallow Dicœum, 120

Swallows, 128

Swallow-Shrike, 129

Swamp Frog, 199, 192

Harrier, 145

Parrot, 135

Quail, 150

Wallaby, 40

Swan, Black, 98

River, 10, 124

Sweep, 205

Swift, 126, 128

Sydney, 13, 15, 22, 23, 52, 78, 103, $118,119,130,131,136,138,139$, $140,141,144,145,147,148,149$, $157,167,198,199,200,201,203$, $209,212,220,227,231,232,236$, $242,248,259,273$

Syma, 116

Synaptura, 199, 239

$\mathrm{T}$

Tachypetes, 94

Tail of Bettong, 44 
Tail of Death Adder, 169

Kangaroo, 33, 34

Lyre Bird, 130

Opossums, 49, 51

Thylacine, 66

Water Snakes, 174

Tailor Bird, 132

Fish, 231

Talleygalan, 232

Tallegallus, 153, 154

Tambreet, 75

Tanysiptera, 117

Tapoa, 69

Tarantulas, 276

Tarsipes, 57

Tarwhine, 226

Tasmania, 5, 6, 11, 13, 15, 21, 41, $42,43,51,53,57,61,65,66,68$, $78,79,95,97,99,100,110,114$, $116,117,118,120,121,124,125$, $126,135,136,137,138,139,140$, $141,143,144,146,158,160$ f.n., $169,170,171,172,198,201,205$, 215, 226, 230 f.n., 240, 242, 247, 248, 265, 277

Tasmanian Devil, 65, 67 Wolf, 65, 66

Tassel Fish, 212 f.n.

Teal, 100

Tee-tee, 91

Teeth of Fish, 197, 210, 238

Frogs, 191

Kangaroos, 35, 36

Myrmecobius, 65, 70

Platypus, 77

Snakes, 165, 174, 175

Wombats, 59

Teleosteans, 236

Temminck (quoted), 14

Tenebrionida, 271

Tenison-Woods (quoted), 198, 212, 215,243

Tenthredinida, 268

Terns, 92, 93

Tetrodon, 247

Teuthis, 231 f.n.

Thalasseus, 93

Thalassochelys, 188

Thick-bellied Quail, 150
Thickheads, 140

Thresher, 222

Threskiornis, 103

Thursday Island, 148, 188, 260

Thylacine, 29, 66

Thynnida, 267

Ticks, 69, 276

Tiger Cat, 57, 68

Prawn, 278

Shark, 221

Snake, 171

Titiqua, 179, 182

Timor, 15

Tinea, 263

Tippet Grebe, 93

Toad Fish, 210, 247

Toads, 191

Todirhamphus, 116

Top Knot, 147

Torres Strait, 175

Tortoises, 188

Pigeon, 148

Tortrices, 264

Townsville, 143, 226

Trachinida, 237, 258

Trachysaurus, 178

Traglin, 205, 234

Tree Creepers, 116, 138

Frogs, 191

Kangaroos, 28, 32, 42

Snakes, 168

Trepang, 280

Trevally, 231

Tribonyx, 102

Trichoglossus, 126

Tringa, 103

Tropic Bird, 94

Tropidechis, 173

Tropidorhynchus, 119

Trout, 198

Trumpeter, Bastard, 235

Real, 199, 205, 234

Silver, 235

Tuatera, 158

Tula, 51

Turdus, 134

Turkey, Wild, 109

Turnix, 150

Turnstone, 103 
Turtles, 188, 280

"Twenty-eight," 125

Tympanocryptis, 182

Typhlops, 167

Urquamata, 72

V

"Van Diemen's Land Jackass," 116

Variable Leatherjacket, 247

Varanus, 179

Varied Lorikeet, 126

Vermicella, 173

Vespertilio, 15

Vesperugo, 15

Victoria, 7, 53, 57, 59, 78, 100, 140, 143, 160 f.n., 169, 201, 240

Victoria river, 10

Violet Snails, 258

Voles, 8, 11

\section{W}

Wading Birds, 101

Wallaby, 32, 39, 40

Wallace (quoted), 7, 148, 209

Wallace's Standard Wing, 138

Wallaroo, 32, 40, 88

Warblers, 135

Warrigal, 4

Warty-faced Honey Eater, 119

Wasps, 265

"Watchman," 140

Water Beetles, 270 Fowl, 89

Hole, 11, 15, 35

Lizards, 177, 186

Rats, 8, 11

Snakes, 173

Wattle Bird, 118

Wattled Plover, 103

Weaver, 133

Weedupwee, 137

Weevers, 198, 236, 238 f.n.
Weevils, 272

Wedge-tailed Eagle, 143

Wels, 241

Western Australia, 11, 14, 51, 57, $70,99,102,117,118,120,124$, $125,126,128,136,137,138,140$, $149,167,179,192$

Whales, 3, 20

Wheelwright (quoted), 77, 99, 135, 161

Whelks, 259

Whimbrel, 103

Whip Snake, 172

Whistling Eagle, 143

Hawk, 143

Tree Duck, 100

White Ant, 153, 273

-backed Magpie, 140

-bellied Sea Eagle, 142

Eye, 136

Frog, 248

Goshawk, 144

-headed Fruit Pigeon, 149

Magpie, 140

Man's Bird, 102

Nutmeg Pigeon, 148

Pointer, 223

-rumped Wood Swallow, 129

-shafted Fantail, 139

-tailed Kingfisher, 117

-tipped Rat, 9

Whitings, 197, 209

Wilcocks (quoted), 225

Wild Boar, 164 Turkey, 109

Wireworm, 271 f.n.

Wirrah, 200, 224

Wobbegong, 221, 223

Wolf, 5, 65

Wollomi, 225

Wombat, 28, 59

Wonga-wonga, 148

Wood (quoted), 20, 69, 99

Wood Duck, 100

Hens, 88

Louse, 268

Peckers, 137

Swallows, 129, 150

Worms, 279 
Wrasses, 198, 237, 252

Wren, 135

Emu, 136

X

Xenorhynchus, 109

Y

Yass, 137

Yelkie, 70

Yellow Bill, 90

-billed Kingfisher, 116

-eared Robin, 141

-finned Leatherjacket, 247

Tail, 208, 231
Yellow Throat, 119 -tufted Honey Eater, 118

"Young 'Un," 19

Ypicaha, 112

“ Zebra,” 66

Parrakeet, 125

Zonceginthus, 138

Zoological Gardens, 5, 17, 29, 32, $43,52,54,61,67,68,98,99$, $104,110,123,124,136,140,144$, $152,157,179,192$

Zosterops, 136

Zygana, 223

THE END.

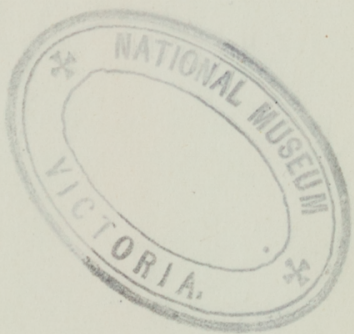

RICH.IRD CLAY AND SONS, LIMITED LONDON AND BUNGAY. 



$508: 3$

AF52 
